\title{
Organizacijska kultura in organizacijska klima
}

Uredila

Melita Moretti

Mirko Markič

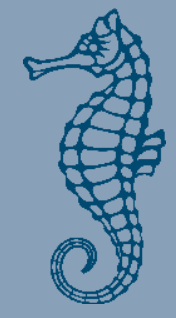


University of Primorska Press

Editorial Board

Katarina Babnik

Štefan Bojnec

Aleksandra Brezovec

Boris Horvat

Dejan Hozjan

Alenka Janko Spreizer

Alen Ježovnik

Lenka Kavčič

Alan Orbanič

Gregor Pobežin

Andraž Teršek

Jonatan Vinkler
Faculty of Management Monograph Series

Editor in Chief

Matjaž Novak

Editorial Board

Ana Arzenšek

Štefan Bojnec

Dubravka Celinšek

Armand Faganel

Viktorija Florjančič

Borut Kodrič

Suzana Laporšek

Mirko Markič

Franko Milost

Matjaž Nahtigal

Mitja Ruzzier

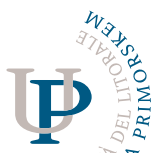

UNIVER Z 


\section{Organizacijska kultura in organizacijska klima}

Teorija, praksa in raziskave v Sloveniji

Uredila

Melita Moretti

Mirko Markič

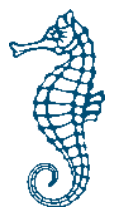


Organizacijska kultura in organizacijsk a klima:

Teorija, praksa in raziskave $v$ Sloveniji

Uredila Melita Moretti in Mirko Markič

Recenzenta

Boštjan Antončič

Matjaž Mulej

Lektura: Davorin Dukič

Prelom in priprava za izdajo: Jonatan Vinkler

Izdala

Založba Univerze na Primorskem

(za založnika: prof. dr. Dragan Marušič, rektor)

Titov trg 4, SI-600o Koper

Glavni urednik

Jonatan Vinkler

Vodja založbe

Alen Ježovnik

Koper 2017

ISBN 978-96I-7023-65-7 (pdf)

http://www.hippocampus.si/ISBN/978-96I-7023-65-7.pdf

ISBN 978-96I-7023-66-4 (html)

http://www.hippocampus.si/ISBN/978-961-7023-66-4/index.html

DOI: https://doi.org/10.26493/978-96I-7023-65-7

(C) 2017 Univerza na Primorskem

Izdaja je sofinancirana po pogodbi ARRS za sofinanciranje izdajanja znanstvenih monografij v letu 2017.

\section{(c) (i) (ㅇ)}

Kataložni zapis o publikaciji (CIP) pripravili v Narodni in univerzitetni knjižnici v Ljubljani

COBISS.SI-ID $=293223424$

ISBN 978-96I-7023-65-7 (pdf)

ISBN 978-961-7023-66-4 (html) 


\section{Vsebina}

9 Slike

II Preglednice

15 Melita Moretti in Mirko Markič • Predgovor

I8 Literatura

\section{Organizacijska kultura in organizacijska klima}

23 I: Melita Moretti - Organizacijska kultura: temelji, opredelitev, raziskovanje, merilni inštrumenti

23 Temelji organizacijske kulture

25 Opredelitev organizacijske kulture

3I Metodologije raziskovanja organizacijske kulture

33 Primeri kvantitativnih merskih inštrumentov merjenja organizacijske kulture

37 Povzetek poglavja

38 Literatura

45 2: Melita Moretti • Nastanek (oblikovanje), obstoj (socializacija), revizija in spreminjanje organizacijske kulture

45 Nastanek (oblikovanje) organizacijske kulture

47 Obstoj (socializacija) organizacijske kulture

49 Revizija organizacijske kulture in njeno spreminjanje

52 Povzetek poglavja

53 Literatura

55 3: Petra Setničar in Mirko Markič • Organizacijska kultura in učinkovitost organizacije

58 Povzetek poglavja

59 Literatura 
6I 4: Melita Moretti - Organizacijska klima: zgodovina, pojem in dimenzije

6I Zgodovina raziskovanja organizacijske klime

63 Pojem organizacijske klime in njene dimenzije

67 Povzetek poglavja

68 Literatura

77 5: Melita Moretti in Mirko Markič • Organizacijska klima in poslovanje organizacije

77 Organizacijska klima in zdravje zaposlenih

78 Organizacijska klima in vpetost invalidnih oseb v organizaciji

79 Organizacijska klima in uspešno staranje zaposlenih

8o Organizacijska klima ter varnost in zdravje pri delu

8I Organizacijska klima in inovativnost

82 Povzetek poglavja

83 Literatura

91 6: Melita Moretti • Organizacijska kultura in organizacijska klima:

Kako blizu in narazen sta si? Kaj se raziskovalci posameznih konstruktov lahko učijo eden od drugega?

92 Podobnosti med organizacijsko kulturo in organizacijsko klimo

93 Razlike med organizacijsko kulturo in organizacijsko klimo

95 Kaj se preučevalci posameznega konstrukta lahko naučijo eden od drugega?

97 Povzetek poglavja

98 Literatura

\section{Različni vidiki organizacijske kulture in organizacijske klime: empirične raziskave $\mathrm{v}$ Sloveniji}

I037: Sonja Belac in Mirko Markič • Organizacijska kultura v izbrani organizaciji javnega sektorja

I04 Namen raziskave

I05 Opredelitev populacije

I06 Vprašalnik

I06 Zbiranje podatkov

107 Rezultati raziskave

I25 Predlogi za izboljšanje

I27 Povzetek ugotovitev raziskave

I28 Prispevek k znanosti

I29 Predlogi za nadaljnje raziskave

I3I Literatura

133 8: Petra Setničar in Mirko Markič • Organizacijska kultura v slovenskih gledališčih

$\mathbf{1 3 3}$ Populacija in vzorec

I35 Opis instrumenta

I37 Analiza in interpretacija raziskave 
166 Ugotovitve iz raziskave

167 Predlogi za izboljšave

I69 Prispevek k znanosti

I69 Predlogi za nadaljnje raziskovanje

170 Literatura

171 9: Benjamin Kmetec in Mirko Markič • Organizacijska kultura in finančna dodana vrednost $\mathrm{v}$ tujih podjetjih $\mathrm{v}$ Sloveniji

I72 Namen raziskave

172 Opredelitev vzorca in potek raziskave

173 Vprašalnik

I74 Zbiranje podatkov

174 Obdelava podatkov

175 Izidi raziskave

193 Preverjanje hipotez

194 Sklepi iz raziskave

195 Predviden prispevek k znanosti

196 Literatura

I99 Iо: Tadeja Skok Matko in Mirko Markič • Organizacijska kultura

v izbranih slovenskih srednje velikih in velikih podjetjih v Sloveniji

200 Namen raziskave

200 Postopek in vzorec

201 Opis merskega instrumenta

202 Analiza in interpretacija raziskave

210 Preverjanje hipotez

213 Sklepi iz raziskave

214 Predlogi za izboljšave

216 Prispevek k znanosti

216 Predlogi za nadaljnje raziskovanje

217 Literatura

219 II: Nataša Kežman in Mirko Markič • Organizacijska klima v slovenskih zdraviliščih

220 Namen raziskave

220 Metodologija

224 Populacija in vzorec

225 Postopki zbiranja podatkov

225 Rezultati raziskave

239 Analiza hipotez

246 Sklepi iz raziskave

249 Predlogi ukrepov za izboljšanje organizacijske klime

250 Prispevek k znanosti

250 Predlogi za nadaljnje raziskovanje

25I Literatura 
Organizacijska kultura in organizacijska klima

253 Recenziji

253 I

254 II 


\section{Slike}

34 Slika I.I: Model konkurenčnih vrednot - CVF

48 Slika 2.I: Proces socializacije

I09 Slika 7.I: Histagrami s prikazom frekvenčne porazdelitve podatkov zaznave trenutnega stanja po posameznih tipih organizacijskih kultur

III Slika 7.2: Histagrami s prikazom frekvenčne porazdelitve podatkov želenega stanja po posameznih tipih organizacijskih kultur

113 Slika 7.3: Obstoječa in želena organizacijska kultura v AJPES - skupni izid

II4 Slika 7.4: Grafični prikaz profila zaznane in želene organizacijske kulture pri temeljnih značilnostih delovnega okolja

II5 Slika 7.5: Grafični prikaz profila zaznane in želene organizacijske kulture pri voditeljstvu v AJPES

I16 Slika 7.6: Grafični prikaz profila zaznane in želene organizacijske kulture pri ravnanju z zaposlenimi

II7 Slika 7.7: Grafični prikaz profila zaznane in želene organizacijske kulture pri vezeh med zaposlenimi

II9 Slika 7.8: Grafični prikaz profila zaznane in želene organizacijske kulture pri strateških poudarkih

I20 Slika 7.9: Grafični prikaz profila zaznane in želene organizacijske kulture pri sodilih uspešnosti

138 Slika 8.I: Glavne značilnosti organizacije

139 Slika 8.2: Stil vodenja

I40 Slika 8.3: Ravnanje z zaposlenimi

I4I Slika 8.4: Povezovalne sile organizacije

I42 Slika 8.5: Strateški poudarki 
Organizacijska kultura in organizacijska klima

143 Slika 8.6: Merilo uspeha

I44 Slika 8.7: Tip organizacijske kulture - sedanje in želeno stanje v organizaciji

I82 Slika 9.I: Vrednosti spremenljivk posameznega tipa organizacijske kulture

I84 Slika 9.2: Vrednosti spremenljivk posameznega tipa organizacijske kulture

192 Slika 9.3: Poslovni izid podjetij raziskovalnega vzorca v \%

193 Slika 9.4: Poslovni izid podjetij raziskovalnega vzorca v številu podjetij

194 Slika 9.5: Ocena želene organizacijske kulture po področju dela

209 Slika ı.ı: Povprečje strukture organizacijskih kultur podjetij, ki so sodelovala $\mathrm{v}$ raziskavi

227 Slika II.I: Organiziranost

228 Slika II.2: Strokovna usposobljenost in učenje

IO

228 Slika Ir.3: Odnos do kakovosti

229 Slika II.4: Nagrajevanje

229 Slika II.5: Notranje komuniciranje

230 Slika ir.6: Notranji odnosi

230 Slika Ir.7: Vodenje

23I Slika II.8: Pripadnost organizaciji

23I Slika Ir.9: Poznavanje vizije in poslanstva ter smotrov in ciljev organizacije

232 Slika II.IO: Motivacija in zavzetost zaposlenih

232 Slika II.II: Razvoj kariere v organizaciji

233 Slika II.I2: Zadovoljstvo zaposlenih 


\section{Preglednice}

30 Preglednica I.I: Razlike med močno in šibko organizacijsko kulturo

32 Preglednica I.2: Prednosti in slabosti raziskovalnih metod preučevanja organizacijske kulture

46 Preglednica 2.I: Mehanizmi vpliva ustanoviteljev organizacije na organizacijsko kulturo

93 Preglednica 6.I: Podobnosti med organizacijsko kulturo in organizacijsko klimo

94 Preglednica 6.2:Razlike med organizacijsko kulturo in organizacijsko klimo

Io8 Preglednica 7.I: Demografski podatki anketiranih oseb

II Preglednica 7.2: Prevladujoči tip organizacijske kulture glede na različne vidike organizacijske kulture

II3 Preglednica 7.3: Primerjava obstoječe in želene organizacijske kulture - skupni izid

I2I Preglednica 7.4: Zaznavanje organizacijske kulture glede na vrsto zaposlitve

I2I Preglednica 7.5: Zaznavanje odpora do sprememb

134 Preglednica 8.r: Demografska struktura anketirancev

138 Preglednica 8.2: Glavne značilnosti organizacije

139 Preglednica 8.3: Stil vodenja

I40 Preglednica 8.4: Ravnanje z zaposlenimi

14I Preglednica 8.5: Povezovalne sile organizacije

142 Preglednica 8.6: Strateški poudarki

143 Preglednica 8.7: Merilo uspeha

I44 Preglednica 8.8: Tip organizacijske kulture - sedanje in želeno stanje v organizaciji

147 Preglednica 8.9: Povprečne vrednosti obstoječih tipov kulture

I47 Preglednica 8.I0: Povprečni rangi posameznih tipov kulture 
I48 Preglednica 8.II: Testna statistika - prevladujoči tip kulture

149 Preglednica 8.I2: Rangi - glavne značilnosti organizacije

149 Preglednica 8.13: Testna statistika - glavne značilnosti organizacije

150 Preglednica 8.I4: Rangi - stil vodenja

I50 Preglednica 8.I5: Testna statistika - stil vodenja

I5I Preglednica 8.ı6: Rangi - ravnanje z zaposlenimi

I5I Preglednica 8.17: Testna statistika - ravnanje z zaposlenimi

152 Preglednica 8.18: Rangi - povezovalne sile organizacije

152 Preglednica 8.19: Testna statistika - povezovalne sile organizacije

153 Preglednica 8.20: Rangi - strateški poudarki

I53 Preglednica 8.21: Testna statistika - strateški poudarki

154 Preglednica 8.22: Rangi - merilo uspeha

154 Preglednica 8.23: Testna statistika - merilo uspeha

155 Preglednica 8.24: Vrednosti OCAI - sedanje stanje

156 Preglednica 8.25: Statistika skupin

I56 Preglednica 8.26: Test enakosti povprečja skupin

157 Preglednica 8.27: Znotrajskupinska matrika

157 Preglednica 8.28: Log dejavniki

I57 Preglednica 8.29: Testni rezultati

158 Preglednica 8.30: Koeficienti

158 Preglednica 8.31: Osnovna statistika

160 Preglednica 8.32: Komponentna matrika

162 Preglednica 8.33: Pravokotna rotacija faktorjev zadovoljstva zaposlenih

164 Preglednica 8.34: Korelacije med faktorji pri pravokotni rotaciji

I65 Preglednica 8.35: Povezanost dejavnikov zadovoljstva in tipov organizacijske kulture - sedanje stanje

I65 Preglednica 8.36: Povezanost dejavnikov zadovoljstva in tipov organizacijske kulture - želeno stanje

175 Preglednica 9.I: Test normalne porazdelitve

I76 Preglednica 9.2: Demografska struktura vzorca I

176 Preglednica 9.3: Demografska struktura vzorca 2

178 Preglednica 9.4: Deskriptivni podatki o dejanskem stanju organizacijske kulture

178 Preglednica 9.5: Deskriptivni podatki o dejanskem stanju organizacijske kulture

I80 Preglednica 9.6: Deskriptivni podatki o želenem stanju organizacijske kulture

I8I Preglednica 9.7: Deskriptivni podatki o želenem stanju organizacijske kulture po sklopih

I83 Preglednica 9.8: Deskriptivni podatki o želenem stanju organizacijske kulture po sklopih

I85 Preglednica 9.9: Pearsonov koeficient korelacije za pare spremenljivk štirih organizacijskih kultur po sklopih

I86 Preglednica 9.10: Korelacijska matrika

I88 Preglednica 9.II: Celotna pojasnjena varianca 
188 Preglednica 9.12: Faktorske uteži (rotacija)

I9I Preglednica 9.13: Regresijska analiza

203 Preglednica ro.I: Število podjetij po dejavnosti, starosti in številu zaposlenih

204 Preglednica I0.2: Število podjetij glede na prevladujoči tip organizacijske kulture

204 Preglednica I0.3: Prevladujoče značilnosti organizacije

205 Preglednica 10.4: Vodenje organizacije

206 Preglednica i0.5: Management zaposlenih

206 Preglednica 10.6: Organizacijska povezanost

207 Preglednica io.7: Strateške usmeritve

208 Preglednica ro.8: Kriteriji uspešnosti

210 Preglednica I0.9: Deskriptivne statistike indeksa onesposabljanja pri skupinah podjetij z enakim prevladujočim tipom organizacijske kulture

2 Io Preglednica ro.ı: Deskriptivne statistike odstotka bolniškega staleža glede na dejavnost podjetja

2II Preglednica I0.II: Primerjava variance odstotka bolniškega staleža organizacij z organizacijsko kulturo tipa trg z varianco odstotka bolniškega staleža organizacij z drugačnim tipom organizacijske kulture

212 Preglednica IO.I2: Primerjava variance odstotka bolniškega staleža organizacij z organizacijsko kulturo tipa klan z varianco odstotka bolniškega staleža organizacij $\mathrm{z}$ drugačnim tipom organizacijske kulture

226 Preglednica II.I: Demografske značilnosti anketiranih

226 Preglednica II.2: Razvrstitev slovenskih zdravilišč glede na prihodek na zaposlenega

234 Preglednica II.3: Korelacija med prihodki na zaposlenega in dejavniki organizacijske klime

236 Preglednica II.4: Analiza variance ANOVA

239 Preglednica II.5: Korelacija med prihodki na zaposlenega in dejavniki notranjih odnosov

240 Preglednica ir.6: Analiza variance ANOVA, hipoteza $\mathrm{H}_{\mathrm{I}}$

24I Preglednica II.7: Korelacija med prihodki na zaposlenega in dejavniki motivacije in zavzetosti

242 Preglednica ir.8: Analiza variance ANOVA, hipoteza $\mathrm{H}_{2}$

244 Preglednica Ir.9: Korelacija med prihodki na zaposlenega in dejavniki vodenja

245 Preglednica Ir.Io: Analiza variance ANOVA, hipoteza $\mathrm{H}_{3}$ 



\section{Predgovor}

\section{Melita Moretti in Mirko Markič}

Monografija opisuje nastanek in naravo organizacijske kulture ter organizacijske klime in poda oceno organizacijske kulture ter organizacijske klime z namenom boljšega razumevanja podjetja ali druge organizacije ter njene uspešnosti. Osredotočamo se na tri glavne cilje.

Prvi glavni cilj monografije sta spodbujanje razmišljanja in izvedba raziskav na področju organizacijske kulture ter organizacijske klime, ker naj bi bilo preučevanje obeh konstruktov v jedru študij o organizaciji (Giorgi, Lockwood in Glynn 2015). Po začetnem interesu za njuno preučevanje med letoma 1980 in 1990 sta organizacijska kultura in organizacijska klima danes namreč ponovno $\mathrm{v}$ jedru zanimanja teoretikov, raziskovalcev in praktikov (Weber in Dancin 201 I). Organizacijska kultura in organizacijska klima predstavljata enega izmed ključnih virov organizacije za njeno trajnostno konkurenčnost (Barney, Ketchen in Wright 20I I). Sta prevladujoči predpogoj za uspešnost podjetja (Flamholtz in Randle 20I4). S teoretičnim pregledom do sedaj opravljenih tujih raziskav ter predstavitev izvedenih raziskav s področja organizacijske kulture in organizacijske klime v Sloveniji smo ugotovili, da raziskave s področja organizacijske kulture lahko služijo kot dodana vrednost pri raziskavah $s$ področja organizacijske klime in obratno, da raziskave s področja organizacijske klime lahko služijo kot dodana vrednost pri raziskavah s področja organizacijske kulture, ter na ta način pripomorejo $k$ razlagi številnih praktičnih vprašanj s področja sprememb v organizacijah.

Drugi glavni cilj monografije je predstaviti kar najbolj celovit vpogled v teoretična izhodišča o pojmih organizacijske kulture in organizacijske klime. V tej monografiji se osredotočamo na predstavitev obeh kon- 
struktov, poiščemo morebitne povezave in razlike med njima ter opišemo področja širitve raziskovanja organizacijske klime, ki so običajno v domeni raziskovalcev organizacijske kulture in ki bi lahko izboljšala konceptualne temelje teorije, raziskave in prakse s področja organizacijske klime (osredotočenost na globljo raven psihologije organizacije, širitev nabora posameznih spremenljivk, vključno z miti, zgodbami, itd., raziskovanje širšega segmenta zunanjega družbenega in naravnega okolja, $v$ katerem organizacija deluje, ter uporaba tudi kvalitativnih metod raziskovanja), ter opišemo področja širitve raziskovanja organizacijske kulture, ki jih uporabljajo tudi raziskovalci s področja preučevanja organizacijske klime (povečanje preučevanja odnosa med organizacijsko kulturo in uspešnostjo organizacije, uporabo t. i. moderatorjev - dejavnikov, preko katerih ima organizacijska kultura posreden vpliv na uspešnost organizacije, in uporabo mešanih metod raziskovanja).

Tretji glavni cilj monografije je predstaviti različne vidike organizacijske kulture in organizacijske klime s pomočjo izvirnih kvantitativnih raziskav v Sloveniji (osredotočamo se na predstavitev izidov raziskav, ki so bile izvedene v več organizacijah skupaj oziroma v organizacijah $\mathrm{z}$ večjim številom organizacijskih enot). Poudarek pri opisu izvedenih raziskav namenjamo prispevku $\mathrm{k}$ znanosti, tako $\mathrm{v}$ teoriji kot $\mathrm{v}$ praksi. Na podlagi ugotovitev izvedenih raziskav smo zasnovali predloge ukrepov za izboljšanje organizacijske kulture in klime v izbranih organizacijah. Predlogi za izboljšanje bodo imeli predvsem praktične koristi za vse tiste, ki si prizadevajo za uspešnost podjetij in drugih organizacij.

Monografija je sestavljena iz dveh glavnih delov. V prvem smo preučili strokovno literaturo s področja konstruktov organizacijske kulture in organizacijske klime, $\mathrm{v}$ drugem pa predstavimo različne vidike organizacijske kulture in organizacijske klime s pomočjo izvirnih kvantitativnih raziskav v Sloveniji.

Prvi glavni del obsega šest poglavij (I-VI), v katerih: prinašamo pregled zgodovine raziskovanja organizacijske kulture, opis pojma organizacijske kulture, njenih subkultur in njenih dimenzij, opis metodologij raziskovanja ter opis glavnih merilnih inštrumentov kvantitativnega raziskovanja organizacijske kulture (prvo poglavje); opisujemo vplivne dejavnike na nastanek in oblikovanje organizacijske kulture, prikazujemo obstoj (socializacijo), revizijo in spreminjanje kulture v organizaciji (drugo poglavje); poudarjamo vpliv organizacijske kulture na opredeljevanje politike organizacije ter na udejanjanje strategij za doseganje smotrov in ciljev v organizaciji (tretje poglavje); prinašamo pregled zgodovine raziskovanja organizacijske klime, predstavljamo pojem organizacijske klime 
in njenih dimenzij ter nadzorovano in nenadzorovano spreminjanje organizacijske klime v podjetju ali drugi organizaciji (četrto poglavje); poudarjamo vpliv organizacijske klime na učinkovitost organizacije (peto poglavje); v zadnjem, šestem poglavju pa oba konstrukta združimo na način, ki koristi tako raziskavam kot praksi na tem področju, saj predstavimo podobnosti in razlike med organizacijsko klimo in organizacijsko kulturo ter opišemo načine, kako preučevanja oziroma ugotovitve iz raziskav enega konstrukta koristijo drugemu in obratno. Pri pisanju se avtorji posameznih poglavij v prvem delu monografije nismo osredotočili na celoten pregled literature obravnavanega področja, temveč predvsem na pregled dosedanjih tujih in domačih raziskav s področja organizacijske kulture ter organizacijske klime. Ti povzetki naj bi zagotavljali dobro izhodišče za morebitni podrobnejši pregled posameznih vsebin in tem za bodoče raziskovanje.

Drugi glavni del vsebuje pet poglavij (VII-XI), kjer predstavimo različne vidike organizacijske kulture in organizacijske klime s pomočjo izvirnih kvantitativnih raziskav v Sloveniji. Najprej (sedmo poglavje) predstavimo raziskavo organizacijske kulture v izbrani organizaciji javnega sektorja, ki je bila izvedena v vseh njenih 13 organizacijskih enotah in s katero smo ugotavljali sedanjo ter želeno organizacijsko kulturo. Izidi iz raziskave pokažejo, da se sedanja organizacijska kultura statistično značilno razlikuje od želene organizacijske kulture, da je prevladujoča organizacijska kultura v vseh I3. organizacijskih enotah izbrane organizacije enaka in da vodstvo in ostali zaposleni statistično značilno enako dojemajo organizacijsko kulturo. Izidi raziskave kažejo tudi prisotnost odpora do sprememb. Sledi predstavitev raziskave organizacijske kulture v slovenskih gledališčih, s katero smo ugotavljali prevladujoči tip organizacijske kulture (osmo poglavje). Izidi raziskave pokažejo, da v slovenskih gledališčih prevladuje organizacijska kultura hierarhije, da je organizacijska kultura skladna pri večini dimenzij, da ne obstaja razlika v dojemanju organizacijske kulture med organizacijskimi enotami (splošnim, tehničnim, umetniškim) in da tipi organizacijske kulture niso povezani z dejavniki zadovoljstva z delom in delovnimi razmerami. V nadaljevanju predstavimo raziskavo organizacijske kulture in finančne dodane vrednosti v tujih podjetjih v Sloveniji (deveto poglavje). Izidi raziskave pokažejo, da si poslovodstvo tujih podjetij v Sloveniji s pomočjo značilnosti kulture hierarhije in z natančno organizacijsko urejenostjo želi doseči učinkovitejše delovanje organizacije v gospodarskem okolju, ki se odraža v kulturi trga. Izidi raziskave prav tako pokažejo, da si zaposleni v tujih podjetjih v Sloveniji želijo harmoničnega sodelovanja znotraj podjetij, kjer je tudi zaz- 
nava zaposlenih po finančni dodani vrednosti največja, ter da si zaposleni na vodstvenih položajih želijo enak tip organizacijske kulture, kot si ga želijo ostali zaposleni. Predstavimo tudi raziskavo vpliva organizacijske kulture $\mathrm{v}$ izbranih srednje velikih in velikih podjetjih $\mathrm{v}$ Sloveniji glede na odstotek bolniškega dopusta zaposlenih (deseto poglavje). Izidi raziskave pokažejo, da v odstotku bolniškega dopusta med skupinami podjetij glede na njihov tip organizacijske kulture ni statistično značilnih razlik. $\mathrm{Na}$ osnovi omenjenih izidov smo prišli do ugotovitve, da sta organizacijska kultura v izbranih srednje velikih in velikih podjetjih v Sloveniji ter odstotek bolniškega dopusta povsem neodvisni spremenljivki. Sledi predstavitev raziskave organizacijske klime v I3. slovenskih zdraviliščih (enajsto poglavje). Izidi raziskave pokažejo, da so zaposleni v teh slovenskih zdraviliščih posamezne kategorije organizacijske klime v večini ocenili kot srednje dobre. Najbolje so bile ocenjene naslednje kategorije: odnos do kakovosti, motivacija in zavzetost ter inovativnost in iniciativnost. Srednjo pozicijo med ocenjenimi kategorijami zasedajo: pripadnost organizaciji, organiziranost, strokovna usposobljenost in učenje, poznavanje poslanstva in vizije ter smotrov in ciljev. Najslabše pa so zaposleni ocenili naslednje kategorije: notranje odnose, nagrajevanje, notranje komuniciranje in informiranje ter razvoj kariere. Izidi omenjene raziskave prav tako pokažejo, da na finančno donosnost $\mathrm{v}$ slovenskih zdraviliščih statistično značilno vlivajo motivacija in zavzetost zaposlenih sodelavcev ter njihovo vodenje, notranji odnosi pa neposred no ne.

Poleg izčrpnega opisa posameznih empiričnih raziskav (namena, metodologije in izidov iz raziskave) izpostavljamo konkretne predloge za izboljšave, prispevek $\mathrm{k}$ upravnim in organizacijskim vedam ter predloge za morebitno nadaljnje raziskovanje.

\section{Literatura}

Barney, Y. B., D. J. Ketchen in M. Wright. 20I I. »The Future of Resource-Based Theory: revitalization od Decline?« Journal of Management 37 (5): I299-3I5.

Flamholtz, E. G., in Y. Randle. 20r 4. »Implications of Organizational Life Cycles for Corporate Culture and Climate.« V The Oxford Handbook of Organizational Climate and Culture, ur. B. Schneider in K. Marbera, 235-56. New York: Oxford University Press.

Giorgi, S., C. Lockwood in A. M. Glynn. 2015. »The Many Faces of Culture: Making Sense of 30 Years of Research on Culture in Organization Studies.«The Academy of Management Annals 9 (19): I-54. 
Weber, K., in M. T. Dacin. 20I I. »The Cultural Construction of Organizational Life: Introduction to the Special Issue.« Organization Science 22 (2): $287-98$. 



\section{Organizacijska kultura in organizacijska klima}





\title{
I \\ Organizacijska kultura: \\ temelji, opredelitev, \\ raziskovanje, merilni \\ inštrumenti
}

\author{
Melita Moretti
}

\section{Temelji organizacijske kulture}

Preučevanje organizacijske kulture, kakršno poznamo še danes, se je začelo leta 1938 s klasičnim managerskim delom Chesterja I. Barnarda z naslovom The Functions of the Executive in nadaljevalo leta $1979 \mathrm{z}$ objavo odmevnega članka »On Studying Organizational Cultures « Andrewa Marshalla Pettigrewa (Pettigrew 1979), v katerem avtor opiše in nariše postopke raziskovanja organizacijske kulture. Barnard in Pettigrew nista bila prva, ki sta koncept organizacijske kulture uporabila za preučevanje podjetja ali druge organizacije. Omenimo naj še raziskovalce Roethlisbergerja in Dicksona (1939 - preučevala sta vpliv družbenih odnosov na vedenje zaposlenih), Whytea (1943 - preučeval je družbo revnih v Bostonu; 1948 - preučeval je medčloveške odnose v gostinstvu), Gardnerja (1945 - učbenik Medčloveški odnosi v industriji), Jacquesa (195 I - opis vpliva socialnih odnosov na produktivnost), Turnerja (I97 I - knjiga o organizacijah kot mikrokulturah). Je bil pa Petigrewjev članek najodmevnejši v takratnem času. Pojem »kultura« se je pred Pettigrevovim pojavil tudi $\mathrm{v}$ znanstvenih člankih s področja organizacijske klime (npr. Fleishman 1953; Argyris 1957; Gilmer 1961 in 1966). Fleishman (1953) je pojem »kultura« opredelil kot socialne razmere v organizaciji (kot splošne norme za ustrezno vedenje, ki so obstajale v organizaciji). Argyris (1957) je organizacijsko kulturo enačil z vedenjskimi normami. Gilmer (1961; 1966) je bil prav tako osredotočen na preučevanje organizacijske klime, vendar je organizacijsko klimo enačil z organizacijsko kulturo.

Po objavi članka »On Studying Organizational Cultures « (Pettigrew 1979) se je koncept organizacijske kulture še bolj razširil in postal 
priljubljen tako med teoretiki, raziskovalci kot praktiki. Alvesson in Berg (1992) sta med vzroke za priljubljenost preučevanja organizacijske kulture po letu 1980 navedla: (I) splošni družbeni in poslovni vidik zasnove organizacijske kulture v tej dobi, (2) učinkovito trženje zasnove organizacijske kulture med teoretiki, raziskovalci in praktiki ter (3) nezadovoljstvo teoretikov in raziskovalcev s tradicionalnimi pogledi na organizacijo. Med vplivne teoretike in raziskovalce zasnove organizacijske kulture v obdobju 1980-1990 prištevamo avtorje, kot so npr. Ouchi (198I), Deal in Kennedy (1982), Pascale in Athos (1982), Peters in Waterman (1982), Sathe (1985), Schein (1985), Ott (1989) in številni drugi. V tem obdobju so se med teoretiki, raziskovalci in praktiki začeli pojavljati različne razprave in nasprotujoča si stališča o tem, kako je treba organizacijsko kulturo preučevati, tako $\mathrm{s}$ teoretičnega kot $\mathrm{z}$ metodološkega vidika. Te razprave in stališča so povzeli Martin, Frost in O'Neill (2006) in jih razdelili v tri glavne skupine: (I) med tiste, ki zagovarjajo preučevanje organizacijske kulture kot »krovni organizacijski konstrukt «, in tiste, ki zagovarjajo prisotnost multikultur/subkultur v organizacijah; (2) med tiste, ki za preučevanje organizacijske kulture uporabljajo kvalitativno metodologijo raziskovanja, in tiste, ki za preučevanje organizacijske kulture uporabljajo kvantitativno metodologijo raziskovanja; (3) med tiste, ki so organizac,ijsko kulturo preučevali kot način za izboljšanje učinkovitosti organizacije (managerialisti) in tiste, ki so menili, da poslovodstvo s preučevanjem organizacijske kulture nadzoruje zaposlene, ki so na spodnjem nivoju hierarhije organiziranosti (kritični teoretiki). Alvesson in Berg (1992) sta te razprave in stališča s področja preučevanja organizacijske kulture označila kot »kaos« predvsem $s$ pozitivnega vidika preučevanja in dejala: $\gg$ Množica perspektiv, definicij in teorij, ki obstaja na tem področju, kakor tudi ohlapne povezave teh konceptov med njimi, predstavljajo veliko teoretično prednost pri raziskovanju organizacijske kulture. Dejstvo je, da je kultura tako bogata kot življenje samo, tako da bi njena okrnitev na tog okvir ali natančne in absolutne definicije resno zmanjšali njeno prirojeno kompleksnost « (Alvesson in Berg 1992, 48). Teoretiki, raziskovalci in praktiki so $\mathrm{v}$ tem obdobju prišli do ugotovitve, da je organizacijska kultura $\mathrm{v}$ podjetjih in drugih organizacijah integrirana, različna in razdrobljena. Ugotovili so, da obstajajo različne ravni organizacijske kulture ter različne metode za njeno preučevanje, vse te metode pa so primerne za preučevanje in odvisne od tega, kaj posamezne raziskovalce in praktike zanima (Martin 2002).

Podobno kot drugje po svetu se je intenzivnejše raziskovanje organizacijske kulture v Sloveniji začelo v obdobju 1980-1990. Prvi prispevek o 
organizacijski kulturi in njenih motivacijskih in sistemskih determinantah je leta 1986 objavil Sikorski (1986). Leto kasneje so Gorenc idr. (1987) $\mathrm{v}$ poročilu o delu predstavili izide o preučevanju organizacijske kulture z vidika strukture in strategije, uspešnosti organizacije ter organizacijske učinkovitosti in kulture vodenja. Nadalje so tudi drugi začeli preučevati organizacijsko kulturo in stile vodenja (Mesner-Andolšek 1988); nove organizacijske paradigme (Kavčič 1988); organizacijsko kulturo in prilagajanje spremembam v poslovanju (Konrad 1990) in dejavnike uspešne uresničitve strategije podjetja (Kovač 1990). Med študenti dodiplomskega in podiplomskega študija je organizacijska kultura postajala ravno tako priljubljena tematika za raziskovanja, saj so bili v tem obdobju že objavljeni dve diplomski nalogi, tri znanstvena magistrska dela in, leta 1992, tudi prva doktorska disertacija z naslovom $\gg$ Vpliv kulture na organizacijsko strukturo « (Mesner-Andolšek 1992). Med sodobnejšimi teoretiki, raziskovalci in praktiki, ki z različnih vidikov (npr. inovacijsko-invencijskega, družbene odgovornosti, trajnostnega razvoja, podjetništva, managementa ali trženja ipd.) preučujejo organizacijsko kulturo in organizacijsko klimo v slovenskem družbenem okolju, je potrebno omeniti še vsaj naslednje avtorje: Meško Štok idr. (20I0), Tekavčič idr. (2010), Belak idr. (2010); Moretti in Biloslavo (20II), Biloslavo idr. (20I2), Ropar in Moretti (20I4), Antončič idr. (20I5), Šarotar Žižek, Treven in Mulej (20I5), Potočan idr. (2016).

Če povzamemo: za razumevanje in preučevanje organizacijske kulture ni enotnega merila, ker je merilo odvisno od namena preučevanja organizacijske kulture $\mathrm{v}$ podjetju ali drugi ustanovi.

$\mathrm{V}$ poznih devetdesetih in $\mathrm{v}$ začetku leta 2000 pa vse do danes je organizacijska kultura postala »pomemben vidik organizacije in upravljanja $\ll$ (Alvesson 2011, I2).

\section{Opredelitev organizacijske kulture}

Organizacijska kultura je težko opredeljiv, večdimenzionalen pojem, saj ima veliko različnih pomenov, ki jih je težko definirati. Kot zanimivost izpostavimo, da sta raziskovalca Cameron in Ettington (1988) v letih med 1982 in $1986 \mathrm{v}$ svojih delih prispevala $\mathrm{I} 8$ različnih definicij organizacijske kulture, Verbeke, Volgering in Hessels (1998) v letih med 1960 in 1993 pa 54 različnih definicij organizacijske kulture.

Med številnimi definicijami organizacijske kulture se je najbolj uveljavila definicija, ki jo je oblikoval Schein (1985, I 4; 2010, I8): »Organizacijska kultura je vzorec skupnih temeljnih predpostavk, ki jih je kaka skupina odkrila, ko se je učila spopadati s problemi prilagajanja navzven in 
povezovanja navznoter, in ta vzorec se je izkazal za dovolj dobrega, da ga je sprejela, zato po tem vzorcu naučijo nove člane, kako naj dojemajo, mislijo in čutijo v odnosu do teh problemov.«

Schein $(2010,24)$ je organizacijsko kulturo razdelil na tri ravni: artefakte (vidne organizacijske strukture in procesi, opazovano vedenje), vrednote (ideali, cilji, želje, ideologije, racionalizacije) in temeljne predpostavke (podzavest, ki izvira iz prepričanj, vedenj, zaznavanj, mišljenja in čutenja).

V nadaljevanju povzemamo nekatere izbrane definicije organizacijske kulture različnih avtorjev, ki so po našem mnenju, poleg Scheina, pojem organizacijske kulture natančno opredelili.

Nekatere zgodnje definicije organizacijsko opredeljujejo kot:

- $>$ skupno načrtovanje uma« (Hofstede 1980, 25),

- $\gg$ niz simbolov, obredov in mitov, ki zaposlenim sporočajo temeljne vrednote in prepričanja organizacij. « (Ouchi 1981, 165),

- $\gg$ prevladujoč in povezan nabor deljenih vrednot, ki jih izražajo simbolična sredstva, kot so zgodbe, miti, legende, slogani, anekdote in pravljice « (Peters in Waterman 1982, 103),

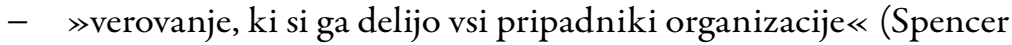
$1983,2)$,

- $\quad \gg$ trdne temeljne vrednote, ki uživajo široko podporo «(O’Reilly I $983, \mathrm{I})$,

- $\quad$ način, kako pri nas delamo« (Deal in Kennedy 1983, 4),

- $\quad \gg s k u p n o$ razumevanje $\ll$ (Van Maanen in Barley 1983, 7),

- $\gg$ nabor deljenih, dolgotrajnih prepričanj, ki se širijo preko različnih simbolnih nosilcev in ki ustvarjajo pomen $\mathrm{v}$ delovnih življenjih ljudi« (Kouzes, Caldwell in Posner 1983, I),

- $\gg n e k a j$ nematerialnega, neizrečenega (neizrazitega) in neoprijemljivega, nekaj, kar se lahko vedno samo indirektno dešifrira. Organizacijske kulture ne moremo secirati v naravoslovnem smislu, ampak jo lahko razložimo oziroma interpretiramo samo preko simbolov. Vsebinsko določa organizacijsko kulturo tisto, kar ima v podjetju nek pomen, kar velja za pozitivno ali negativno, kako se razmišlja o preteklosti ali okolju in kaj menijo ljudje drug o drugem « (Kasper 1987, 5),

- $\gg$ bistvo in duša organizacije (Meek 1988, 454),

- $\quad$ nekaj, kar je dovoljeno, in nekaj, kar ni dovoljeno « (Atkinson 1990, 6),

- $\gg$ kolektivno programiranje duha, po katerem se člani ene človeške skupine razlikujejo od drugih «(Hofstede 1980, 2I). 
Večina novejših definicij organizacijske kulture je povzetih iz prejšnjih del, zato jih nismo posebej navajali. Glede opredelitve organizacijske kulture pa vseeno velja omeniti naslednje novejše teoretike in raziskovalce: Schermerhorn (2013), Mullins (2010), Robbins, Timothy in Judge (2014), Ehrhart, Schneider in Macey (2014), Giorgi, Lockwood in Glynn (2015).

Schermerhorn (2013) organizacijsko kulturo opisuje iz dveh ravni in sicer:

- zunanja, vidna raven organizacijske kulture: izraža se npr. s slogom oblačenja na delovnem mestu, z urejenostjo delovnih prostorov, načinom komunikacije, naravo pogovorov med zaposlenimi, načinom in naravo pogovorov z odjemalci (tudi strankami/kupci/porabniki) podjetja ali druge organizacije; to raven sestavljajo tudi npr. zgodbe, heroji, rituali, simboli, ki naj bi bili sestavni del vsakdanjega življenja organizacije,

- notranja, globlja raven organizacijske kulture - jedro organizacijske kulture: izraža se npr. $\mathrm{z}$ inovativnostjo zaposlenih, etiko in moralo, integriteto, družbeno odgovornostjo in s trajnostnim razvojem, z izvedbo, s timskim delom ipd.; jedro organizacijske kulture naj bi sestavljale temeljne vrednote, predpostavke in prepričanja, ki oblikujejo in usmerjajo vedenje ter obnašanje zaposlenih.

Mullins (2010) organizacijsko kulturo pojmuje kot poslovno-organizacijski sistem upravljanja in managementa - zaposleni sprejmejo organizacijsko kulturo, vrednote organizacijske kulture naj bi povečale moč in avtoriteto upravljalcev ter managerjev na naslednje načine:

- zaposleni se poistovetijo s svojo organizacijo - sprejmejo, »kaj je prav, da naredijo $\ll$,

- zaposleni ponotranjijo vrednote $\mathrm{v}$ organizaciji, če so mnenja, da so pravilne,

- zaposleni so motivirani za doseganje smotrov in ciljev organizacije.

Robbins in Judge (2013) so organizacijsko kulturo definirali kot sistem »skupnega pomena zaposlenih, ki razlikuje organizacijo od drugih organizacij《 (prav tam, 249) - oblikovali so sedem osnovnih značilnosti organizacijske kulture, in sicer:

- inovativnost in tveganja: stopnja, do katere se spodbuja zaposlene $\mathrm{k}$ inovativnosti in stopnja tveganja, 
- pozornost na podrobnosti: stopnja, do katere se od zaposlenih pri delu pričakuje natančnost, pozornost in analizo,

- usmerjenost k izidom: stopnja, do katere se management osredotoča na izide in ne na tehnike in postopke, ki se uporabljajo za doseganje smotra in cilja organizacije,

- usmerjenost k zaposlenim: stopnja, do katere odločitve managerjev upoštevajo vpliv izidov na zaposlene v organizaciji,

- timska usmerjenost: stopnja, do katere so delovne aktivnosti zaposlenih organizirane po skupinah ali timih,

- agresivnost: stopnja, do katere so zaposleni pri svojem delu agresivni in konkurenčni,

- stabilnost: stopnja, do katere se z organizacijskimi aktivnostmi osredinjajo na ohranjanje statusa quo v nasprotju z razvojem.

Ehrhart, Schneider in Macey (2014) so opredelili naslednje značilnosti organizacijske kulture:

- organizacijska kultura je v skupni rabi: vključuje prepričanja, vrednote, dojemanje, razumevanje, vedenje, norme, interpretacije, ideologije, predpostavke itd., ki si jih delijo zaposleni v organizaciji,

- organizacijska kultura je stabilna, kar pomeni, da je v daljšem časovnem obdobju stabilna in se razvija ne glede na spremembe $\mathrm{v}$ družbenem in naravnem okolju, saj predstavlja osrednjo vlogo pri identiteti članov organizacije,

- organizacijska kultura ima globino, pogosto deluje zunaj zavesti zaposlenih v organizaciji,

- organizacijska kultura je simbolična, ekspresivna in subjektivna;

- organizacijska kultura temelji na zgodovini in tradiciji; kultura v organizaciji je odraz preteklosti in učinkovitosti organizacije pri soočanju z različnimi izzivi v daljšem časovnem obdobju,

- organizacijska kultura se prenaša na nove člane (socializacija): prenos posameznih dejavnikov organizacijske kulture (npr. vrednote, prepričanja) v organizaciji na nove zaposlene pomaga, da organizacijska kultura v organizaciji ostaja stabilna,

- z organizacijsko kulturo se zagotavlja red in pravila za obstoj organizacije; funkcija organizacijske kulture v organizaciji je, da se z njo pokaže, kaj se od zaposlenih pričakuje in kaj pri delu velja kot primerno delovanje zaposlenih, 
- organizacijska kultura ima širino: vpliva na vse vidike poslovanja organizacije (npr. na vizijo in poslanstvo, ideologijo, stališča, znanje, fizično podobo ipd.),

- organizacijska kultura je vir kolektivne identitete in predanosti; zaradi skupnih vrednot, prepričanj in osnovnih predpostavk posamezna identiteta postane prepletena $\mathrm{z}$ identiteto skupine kot celote,

- organizacijska kultura je edinstvena; temelji na edinstveni zgodovini skupine posameznikov v organizaciji, ki se skozi zgodovino organizacije spopadajo $\mathrm{z}$ različnimi političnimi, fizičnimi in gospodarskimi okoliščinami.

Če povzamemo, ugotovimo, da je organizacijska kultura kompleksen, večdimenzionalen in večnivojski konstrukt, ki v dejanjih organizacije uresničuje vrednote in etiko, anekdote, artefakte, skupne predpostavke, temeljne predpostavke, način čustvovanja, norme, običaje, mišljenje, obrede, neformalna pravila, filozofijo, fizično podobo organizacije, ideologijo, metafore, predpostavke, prepričanja, proslave, stališča, slog in stil vodenja, tradicijo, vizijo in poslanstvo, vzornike, zgodbe in znanja.

Organizacijska kultura je lahko izrazita, vmesna ali šibka. Robbins in Judge (2013) menita: (I) bolj ko zaposleni sprejemajo temeljne vrednote organizacije, večja je njihova zavzetost za te vrednote in močnejša je organizacijska kultura, in (2) močnejša kot je organizacijska kultura, večji je pritisk na zaposlene, da upoštevajo prevladujoče oblike vedenja in obnašanja v organizaciji. Prisotnost močne organizacijske kulture še ne pomeni, da je ta optimalna in zagotavlja uspešnost organizacije (Kotter and Heskett 1992; Sørensen 2002; Lee in Yu 2004; Flynn in Chatman 2001; Tsui idr. 2006). Po mnenju Sørensena (2002) je močna organizacijska kutura koristna v stabilnih družbenih okoljih, v nestanovitnih družbenih okoljih pa ima na učinkovitost organizacije zmerne učinke moči. Flynn in Chatman (200I) menita, da močna organizacijska kultura ni ovira za inovativnost le $\mathrm{v}$ primeru, če se $\mathrm{z}$ njo poudarjajo kulturne vsebine, ki naj bi tvorile podlage za invencijsko-inovacijske procese. Ostale pomembne razlike so razvidne $\mathrm{v}$ preglednici I.I. 
Preglednica I.I: Razlike med močno in šibko organizacijsko kulturo

\begin{tabular}{ll}
\hline $\begin{array}{l}\text { Temeljne vrednote in etiko organizacije sprejema veči- } \\
\text { na zaposlenih. }\end{array}$ & $\begin{array}{l}\text { Temeljne vrednote in etika organizacije so omejene na } \\
\text { lastnike in managerje. }\end{array}$ \\
\hline $\begin{array}{l}\text { Zaposleni so bolj povezani, lojalni in zavezani organi- } \\
\text { zaciji. }\end{array}$ & $\begin{array}{l}\text { Zaposleni so manj povezani, lojalni in zavezani organi- } \\
\text { zaciji. }\end{array}$ \\
\hline $\begin{array}{l}\text { Med vrednotami in etiko ter vedenjem in obnašanjem } \\
\text { obstaja močna povezanost. }\end{array}$ & $\begin{array}{l}\text { Med vrednotami, etiko in vedenjem ter obnašanjem ob- } \\
\text { staja šibka povezanost. }\end{array}$ \\
\hline Večina zaposlenih pozna zgodbe in mite v organizaciji. & Manjšina zaposlenih pozna zgodbe in mite v organizaciji. \\
\hline $\begin{array}{l}\text { Zaposleni se identificirajo z organizacijo. } \\
\text { Fluktuacija zaposlenih je majhna. }\end{array}$ & $\begin{array}{l}\text { Zaposleni se ne oziroma se šibko identificirajo z orga- } \\
\text { nizacijo. }\end{array}$ \\
\hline Organizacijska kultura se ne spreminja. & Fluktuacija zaposlenih je velika. \\
\hline Močno vpliva na učinkovitost v organizaciji. & Organizacijska kultura se težko spreminja. \\
\hline
\end{tabular}

Viri: Sørensen 2002; Lee in Yu 2004; Tsui idr. 2006; Robbins in Judge 2013.

Tako kot v družbi kot celoti je tudi v podjetju ali drugi ustanovi prisotna mešanica organizacijskih subkultur. Subkulture so z vidika podjetja ali druge ustanove skupine posameznikov v organizaciji, ki sodelujejo, komunicirajo in se hkrati identificirajo kot posebna skupina - delijo si vrednote in etiko, ki se razlikujejo od glavnih vrednot in etike v organizaciji (Van Maanen in Barley 1985; Hitt, Miller in Colella 20 I; Griffin in Moorhead 2014).

Schein (20ro) meni, da v posameznih organizacijah soobstajajo vsaj tri različne subkulture, in sicer:

- operativna subkultura, ki je značilna za zaposlene,;

- inženirska subkultura, ki je značilna za načrtovalce in nadzornike delovnih procesov,

- vodstvena subkultura, ki je značilna za managerje.

$\mathrm{Na}$ oblikovanje subkultur vpliva velikost organizacije (z rastjo števila zaposlenih se spreminja tudi njihova raznolikost - npr. starost, izobrazba, poklic, narodnost, delovna doba ipd.), starost organizacije (s starostjo organizacije vanjo vstopajo novi zaposleni, ki prinašajo nove vrednote in norme) in notranje diferenciacije ( $\mathrm{z}$ večanjem organizacije pride do notranje diferenciacije glede na specializirane funkcije - npr. računovodstvo, trženje, proizvajanje ipd.) (Hitt, Miller in Colella 20II; Schermerhorn 2013; Griffin in Moorhead 2014). Subkulture v organizacijah naj bi oteževale izkoriščanje celotnega potenciala zaposlenih in ustvarjajo »multikulturnost « organizacije. 
Med subkulture Schermerhorn (2013) prišteva:

I. generacijske (starostne) subkulture: starostne razlike posameznikov ustvarjajo t. i. generacijske subkulture v organizacijah (od generacije »baby boom « do generacije interneta) - vsaka generacija ima različne izkušnje in vrednote, ki so lahko (ali pa tudi ne) podlaga za morebitne spore v organizaciji,

2. subkulture glede na spol; primer: (a) če so v skupini samo moški, lahko njihova subkultura tvori takšno konkurenčno vzdušje, kjer za zmage in poraze pri delu uporabljajo športne metafore; (b) če so v skupini samo ženske, njihova subkultura temelji na osebnih odnosih in sodelovanju,

3. etične ali nacionalne subkulture, ki nastajajo med posamezniki v organizaciji, katerim je skupna npr. narodnost, domovina, religija ipd.,

4. poklicne in funkcijske subkulture, ki nastajajo med posamezniki $\mathrm{z}$ enakimi poklici in spretnostmi (npr. v proizvajanju, trženju in financiranju ipd.).

\section{Metodologije raziskovanja organizacijske kulture}

Pri preučevanju organizacijske kulture lahko uporabimo kvalitativni (kvalitativna metodologija raziskovanja) ali kvantitativni (kvantitativna metodologija raziskovanja) pristop raziskovanja.

Kvalitativni pristop raziskovanja omogoča podroben vpogled $\mathbf{v}$ organizacijsko kulturo (Heron in Reason 2006; Ehrhart, Schneider in Macey 20I4). Ta pristop je primeren za analiziranje zgodb in pripovedi (zabeleženega besedila), ki jih o svojih izkušnjah pripovedujejo zaposleni. Vzorec pri kvalitativnem pristopu je majhen in fleksibilen. Najprimernejše metode za kvalitativni pristop raziskovanja organizacijske kulture so intervjuji in fokusne skupine. Analiza zgodb in pripovedi (zabeleženega besedila) se izvede na osnovi kodiranja podatkov (I. identifikacija tem/ključnih pojmov; 2. sortiranje tem/ključnih pojmov $\mathrm{v}$ posamezne kategorije; 3. analiza in interpretacija posameznih kategorij), izidi so predstavljeni v obliki teorije, zgodbe in vzrokov. Analizo se lahko izvede brez uporabe računalniških programov, z njihovo uporabo (npr. ATLAS.ti, Nvivo, QDA Miner, Quirkos) pa se pri veliki količini podatkov prihrani čas, možna pa je tudi vizualna predstavitev podatkov in informacij.

Kvantitativni pristop raziskovanja organizacijske kulture temelji na uporabi merilnega inštrumenta - vprašalnika (Baker 2007; Nylund, Asparouhov in Muthén 2007; Ehrhart, Schneider in Macey 2014). Kvanti- 
tativni pristop raziskovanja je stroškovno učinkovitejši in omogoča širše vzorčenje organizacije, statistično preverjanje prisotnost subkultur in raven sporazuma o organizacijski kulturi ter primerjavo statističnih podatkov skozi daljše obdobje. Posamezne merilne inštumente (OCAI, DOCS, OCI') bomo predstavili v naslednjem podpoglavju. Analiza kvantitativnih podatkov se izvede s pomočjo računalniških programov, kot so npr. SPSS, MATLAB, MaxStat in drugi.

$\mathrm{V}$ preglednico I.2 smo razvrstili posamezne prednosti in slabosti raziskovanja organizacijske kulture, ki so jih podali Ehrhart, Schneider in Macey (2014).

Preglednica 1.2: Prednosti in slabosti raziskovalnih metod preučevanja organizacijske kulture

Omogoča podroben opis organizacijske kulture v podjetju ali drugi organizaciji.

Poda »notranjo perspektivo «, kakšna je organizacijska kultura v organizaciji.

Omogoča preučevanje organizacijske kulture skozi čas.

Lahko se uporablja za preučevanje globljih plasti organizacijske kulture.

Ugotovitve so lahko nepričakovane.

\begin{tabular}{cc}
\multicolumn{3}{c}{ Kvantitativna metodologija } \\
\hline Prednosti & Slabosti \\
\hline
\end{tabular}

Omogoča primerjavo.

Primernejša za prikaz, kako je organizacijska kultura povezana z uspešnostjo.

Primernejša za preverjanje s teorijo.

Za preučevanje globljih nivojev organizacijske kulture ni koristna.

Težko je soditi, ali so vprašanja postavljena primerno in ali so t pomembna za določeno vrsto organizacijske kulture v organizaciji.

Omogoča pregled vseh zaposlenih, vključno z ravnmi in organizacijskimi enotami.

Omogoča statistično preverjanje prisotnosti subkultur in Omogoča pristranskost anketiranih. raven sporazuma o organizacijski kulturi.

Vir: Ehrhart, Schneider in Macey 2014, I42. 


\section{Primeri kvantitativnih merskih inštrumentov merjenja organizacijske kulture}

$\mathrm{V}$ nadaljevanju opišemo tri najpogosteje uporabljene merske inštrumente za merjenje organizacijske kulture, in sicer merilne inštrumente OCAI, DOCS in OCI.

\section{Merski instrument organizacijske kulture OCAI (Cameron in Quinn)}

Merski inštrument organizacijske kulture OCAI (angl. The Organizational Culture Assesment Instrument) temelji na modelu konkurenčnih vrednot (angl. The Competing Values Framework - CVF), ki zajema kombinacijo vedenjskih norm in vrednot zaposlenih ter managementa (Quinn in Rohrbaugh 1983). Po mnenju Allameha, Zamanija in Dovoodija (20I I) model CVF vključuje dokazano oceno za določitev stopnje posameznega tipa organizacijske kulture znotraj podjetja ali druge organizacije. Na podlagi merjenja organizacijske kulture z merskim inštrumentom OCAI dobimo pogled $\mathrm{v}$ delovanje organizacije in njene značilne vrednote ter dobimo informacijo, ali so pričakovanja posameznikov glede prihodnosti organizacije skladna s sedanjim stanjem organizacijske kulture.

Merski inštrument vsebuje šest sklopov vprašanj (šestih ključnih dimenzij posamezne organizacijske kulture), in sicer (Cameron in Quinn 2OII):

- prevladujoče lastnosti organizacije: pripadnost, timsko delo, ustvarjalnost, dinamičnost, usmerjenost, medsebojno zaupanje, poudarjanje učinkovitosti,

- vodenje: dejavniki vodenja, kot so vzgled, mentorstvo, svetovanje, skrb za zaposlene, podjetništvo, inovativnost, pripravljenosti prevzemati tveganje, koordinacija, organiziranje, zagotavljanje sprotne učinkovitosti,

- ravnanje z zaposlenimi: obravnava in stopnja sodelovanja z zaposlenimi,

- lepilo (dejavniki povezovanja) organizacije: skupinsko delo, pripadnost, prilagodljivost, pravila in politika organizacije, pretekli dosežki in napredek,

- strateški poudarki: odnos organizacije do zaposlenih, odnos do inovacij, odnos do rasti in razvoja, odnos do konkurenčnosti,

- merila za uspeh: razvoj zaposlenih, inovacije, prevladujoč položaj na trgu, tržni delež, učinkovitost, sprotno poslovanje. 
Pri vsakem sklopu vprašanj (pri vsaki dimenziji organizacijske kulture) obstajajo štiri alternative, ki predstavljajo eno od štirih različnih splošnih organizacijskih kultur, in sicer (prav tam):

- klan: prožna organizacija, $\mathrm{v}$ kateri se osredinjajo na lojalnost in tradicijo, razvoj zaposlenih, skrb za zaposlene in posluhnejo odjemalcem,

- adhokracija: dinamična, podjetniška in ustvarjalna organizacija, $\mathrm{v}$ kateri se osredinjajo na inoviranje proizvodov in procesov, nenehno rast in pridobivanje novih zmožnosti,

- hierarhija: strukturirana in formalizirana organizacija, $\mathrm{v}$ kateri se osredinjajo na stabilnost, učinkovitost in zagotavljanje sprotnega poslovanja (zanesljivost dobav, izpolnjevanje rokov, nizki stroški poslovanja ipd.),

- trg: $\mathrm{k}$ poslovnim izidom usmerjena organizacija, $\mathrm{v}$ kateri se $s$ pomočjo agresivnih, zahtevnih in nepopustljivih vodij osredinjajo na tekmovalnost in konkurenčno delovanje organizacije (biti prvi - vodilna vloga na trgu, imeti največji tržni delež ipd.).

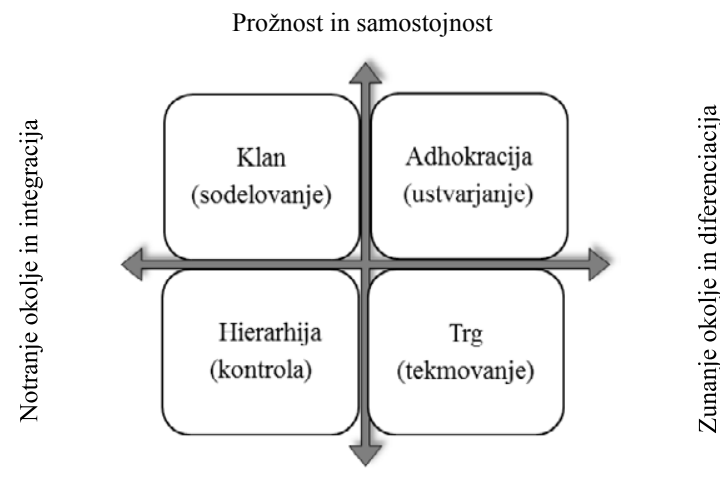

Stabilnost in obvladovanje

Slika I.I: Model konkurenčnih vrednot - CVF

Vir: Cameron in Quinn 201 I, 39.

Ti štirje tipi organizacijskih kultur predstavljajo različne kvadrante, ki so tvorjeni s križanjem dveh razsežnostih: (I) prva razsežnost sega od prožnosti in samostojnosti do stabilnosti in obvladovanja, (2) druga razsežnost pa od notranjega okolja organizacije in integriranja do zunanjega okolja organizacije in diferenciranja (Cameron in Quinn 201 I, 76). Nastala matrika 2 × 2 je prikazana na sliki I.I. 
Znotraj vsakega od šestih sklopov vprašanj anketirani razdelijo ıoo točk (največje število točk razdelijo trditvi, za katero menijo, da opisuje sedanje stanje $\mathrm{v}$ organizaciji in željeno stanje organizacije $\mathrm{v}$ prihodnosti). Cameron in Quinn (20II) navajata, da se povprečne ocene anketiranih analizira na šest različnih načinov, in sicer: (I) s primerjavo po dimenzijah, kateri je prevladujoči tip organizacijske kulture v podjetju ali drugi organizaciji, (2)s primerjavo med sedanjim in želenim tipom organizacijske kulture, (3) z ugotavljanjem moči organizacijske kulture glede na višino povprečne vrednosti točk prevladujočega tipa organizacijske kulture v podjetju ali drugi organizaciji, (4) s primerjavo rezultatov znotraj posameznih skupin $\mathrm{v}$ podjetju ali drugi organizaciji, (s) s primerjavo ocen glede na podatke, ki so bili ugotovljeni pri konkurenčni organizaciji ali panogi, v kateri organizacije deluje, in (6) s primerjavo rezultatov s trendi, ki so bili ugotovljeni z uporabo tega merskega inštrumenta.

Med prednosti merskega inštrumenta organizacijske kulture OCAI prištevamo ustrezno zanesljivost in veljavnost merjenja, časovno ekonomičnost, omogočanje izrisa organizacijskega profila ločeno po dimenzijah in skupno, preprostost vrednotenja ter prost dostop do merskega instrumenta, kot pomanjkljivost pa štejemo ugotovitev, da vprašalnik uradno ni bil preveden $\mathrm{v}$ slovenščino.

\section{Denisonov merski instrument organizacijske kulture DOCS}

$Z$ Denisonovim merskim inštrumentom organizacijske kulture DOCS (angl. Denison Organizational Culture Survey) upoštevamo, prav tako kot z merskim inštrumentom organizacijske kulture OCAI, dve razsežnosti organizacijske kulture, in sicer ( $\mathrm{I}$ ) prva razsežnost sega od prožnosti do stabilnosti, (2) druga razsežnost pa od notranjega okolja do zunanjega okolja organizacije (Denison 1990; Denison in Neale 2000). Uporabljamo ga pri analiziranju in opredeljevanju lastnosti organizacije $\mathrm{z}$ namenom izpostavljanja prednosti in nevarnosti organizacijske kulture $\mathrm{v}$ podjetju ali drugi organizaciji.

Denisonov merski inštrument organizacijske kulture DOCS vsebuje 60 standardiziranih trditev, ki se jih respondenti ocenjujejo na Likertovi lestvici od I (sploh se ne strinjam) do s (popolnoma se strinjam). Trditve so razdeljene na štiri dimenzije organizacijske kulture, in sicer (Denison 1990; Denison, Nieminen in Kotrba 2012; Kotrba idr. 2012):

- poslanstvo (angl. mission): stopnja izraženosti vizije in smeri usmerjanja, 
- konsistentnost (angl. cosistency): v kolikšni meri so prepričanja in vrednote usklajena s politikami in prakso organizacije,

- prilagodljivost (angl. adaptability): prilagodljivost notranjih struktur pri izpolnjevanju zahtev iz zunanjega okolja, predvsem pri odjemalcih,

- sodelovanje (angl. involvement): obseg zaposlenih pri odločanju in timska usmerjenost.

Vsaka izmed dimenzij (poslanstvo, konsistentnost, prilagodljivost in sodelovanje) ima tri poddimenzije, na katere se nanaša pet trditev (prav tam). Zanesljivost in veljavnost merjenja organizacijske kulture z uporabo Denisonega merskega inštrumenta DOCS potrjujejo Denison, Haaland in Goelzer (2003), Fey in Denison (2003) ter Kotrba idr. (2012).

$\mathrm{K}$ prednostim Denisonovega merskega inštrumenta DOCS prištevamo ustrezno zanesljivost in veljavnost merjenja in omogočanje izrisa organizacijskega profila, kot pomanjkljivost pa lahko štejemo, da vprašalnik uradno ni bil preveden v slovenščino, prav tako pa ni prosto dostopen.

\section{Merski inštrument organizacijske kulture $O C I^{\circ}$}

$Z$ uporabo merskega inštrumenta organizacijske kulture OCI (angl. Organizational Culture Inventory ) dobimo vpogled v profil trenutne organizacijske kulture; uporablja se za odkrivanje potreb po preoblikovanju/spremembi organizacijske kulture, za načrtovanje in spremljanje razvojnih programov ipd. (Cooke in Lafferty 1987). Merski inštrument OCI vsebuje 120 trditev, ki se nanašajo na vedenja, za katera anketirani menijo, da so primerna ne glede na pričakovanja v organizaciji (prav tam). $\mathrm{V}$ merskim inštrumentu so upoštevane naslednje razsežnosti organizacijske kulture: (I) prva razsežnost sega od skrbi za ljudi do skrbi za naloge, (2) druga razsežnost pa od varnostnih potreb do zadovoljstva (Balthazard, Cooke in Potter 2006).

Trditve so razdeljene na tri dimenzije organizacijske kulture, in sicer (Ehrhart, Schneider in Macey 2014):

- konstruktivno kulturo (angl. Constructive Culture): poudarek na zaposlenih in nalogah $\mathrm{z}$ namenom izpolnjevanja potreb managerjev,

- pasivno/obrambno kulturo (angl. Passive/Defensive Culture): poudarek na ohranjanju socialne varnosti zaposlenih,

- agresivno/obrambno kulturo (angl. Aggressive/Defensive Culture): poudarek na nalogah z namenom ohranjanja socialne varnosti. 
Vsaka od treh dimenzij organizacijske kulture (konstruktivna, pasivna/obrambna in agresivna/obrambna kultura) zajema štiri vedenjske norme, na katere se nanaša deset trditev. Konstruktivna kultura vključuje dosežke, samorealizacijo, spodbujanje in pripadnost, pasivnoobrambna kultura vključuje odobritev, odvisnost, izogibanje in tradicijo, agresivnoobrambna kultura pa opozicijo, moč, konkurenčnost in perfekcionizem. Anketirani na vsako trditev podajo oceno pričakovanj in zahtev $\mathrm{v}$ organizaciji na Likertovi lestvici od I (sploh ne) do 5 (v veliki meri). Zanesljivost in veljavnost merjenja organizacijske kulture $\mathrm{z}$ uporabo merskega inštrumenta OCI potrjujejo Cooke in Szumal (1993), Xenikou in Furnham (1996), Xenikou in Simoni (2006), Murphy, Cooke in Lopez (2013) ter Chaudhry idr. (2016).

Med prednosti merskega inštrumenta prištevamo merjenje dejavnikov, ki dokazano vplivajo na učinkovitost, kot pomanjkljivost pa štejemo, da vprašalnik ni bil uradno preveden v slovenščino, prav tako pa ni prosto dostopen.

\section{Povzetek poglavja}

Preučevanje organizacijske kulture, kakršno poznamo še danes, se je začelo leta 1938 z Barnardovim klasičnim managerskim delom in nadaljevalo leta $1979 \mathrm{~s}$ Pettigrewom. Za razumevanje in preučevanje organizacijske kulture ni enotnega merila, saj je slednje odvisno od namena preučevanja organizacijske kulture v podjetju ali drugi ustanovi. Organizacijska kultura je kompleksen, večdimenzionalen in večnivojski konstrukt, ki deluje na organizacijo s pomočjo vrednot, anekdot, artefaktov, skupnih predpostavk, temeljnih predpostavk, načina čustvovanja, norm, običajev, mišljenja, obredov, neformalnih pravil, filozofije, fizične podobe organizacije, ideologije, metafor, predpostavk, prepričanj, proslav, stališč, sloga vodenja, tradicije, vizije, vzornikov, zgodb in znanja. Organizacijska kultura v podjetju ali drugi ustanovi je lahko močna ali šibka. Tako kot družba kot celota tudi podjetja ali druge ustanove vsebujejo mešanico organizacijskih subkultur. Na oblikovanje slednjih vplivajo npr. velikost organizacije, starost organizacije, notranja diferenciacija ipd. Organizacijske subkulture $\mathrm{v}$ podjetjih ali drugih ustanovah naj bi oteževale izkoriščanja celotnega potenciala zaposlenih in ustvarjajo $\gg$ multikulturnost $\ll$ organizacije.

Za preučevanje organizacijske kulture lahko uporabimo kvalitativni ali kvantitativni pristop oziroma metodologijo raziskovanja. Kvalitativni pristop je primeren za majhne in fleksibilne vzorce, uporablja se za analiziranje pripovedi (zabeleženega besedila), ki jih o svojih izkuš- 
njah pripovedujejo zaposleni. Najprimernejše metode za kvalitativni pristop raziskovanja organizacijske kulture so intervjuji in fokusne skupine. Kvantitativni pristop raziskovanja organizacijske kulture temelji na uporabi merskega inštrumenta (vprašalnika, npr. OCAI, DOCS, OCI'), je stroškovno učinkovitejši, omogoča širše vzorčenje organizacije ter statistično preverjanje prisotnost subkultur in raven sporazumnosti o organizacijski kulturi.

\section{Literatura}

Allameh, M., Z. Zamani in S. M. R. Davoodi. 20II. »The Relationship between Organizational Culture and Knowledge Management (A Case Study: Isfahan University).« Procedia Computer Science 3 (I): 1 224-36.

Alvesson, M. 20I . »Organizational Culture: Meaning, Discourse, and Identity.« V Handbook of organizational culture and climate, ur. N. M. Ashkanasy, C. P. M. Wilderom in M. F. Peterson, II-28. Thousand Oaks: Sage.

Alvesson, M., in P. O. Berg. 1992. Corporate Culture and Organizational Symbolism. New York: de Gruyter.

Antončič, B., T. Bratkovič Kregar, G. Singh in A. F. DeNoble. 2015. »The Big Five Personality-Entrepreneurship Relationship: Evidence from Slovenia.«Journal of small business management 53 (3): 819-4I.

Argyris, C. 1957. Personality and Organization. New York: Harper \& Bros.

Atkinson, P. E. 1990. »Creating Cultural Change.« Management Services 34 (7): 6-10.

Baker, J. A. 2007. The Report of the BP US Refineries Independent Safety Review Panel. New York: CCPS.

Balthazard, P. A., R. A. Cooke in R. E. Potter. 2006. »Dysfunctional Culture, Dysfunctional Organization: Capturing the Behavioral Norms that Form Organizational Culture and Drive Performance.«Journal of Managerial Psychology 2 I (8): 709-32.

Barnard, C. I. 1938. The Functions of the Executive. Cambridge, MA: Harvard University Press.

Belak, J., M. Duh, M. Mulej in T. Štrukelj. 20ı o. »Requisitely Holistic Ethics Planning as Pre-condition for Enterprise Ethical Behaviour.« Kybernetes 39 (I): 19-36.

Biloslavo, R., A. Fagnel, B. Kodrič in A. Trnavčevič. 2or 2. Marketinška kultura v storitvenih dejavnostih. Koper: Univerza na Primorskem, Fakulteta za management. 
Cameron, K. S., in D. R. Ettington. 1988. »The Conceptual Foundations of Organizational Culture.«V Higher education: Handbook of theory and research, ur. J. C. Smart, 356-96. New York: Agathon.

Cameron, K. S., in R. E. Quinn. 201 r. Diagnosing and Changing Organizational Culture: Based on the Competing Values Framework. San Francisco, CA: Wiley.

Chaudhry, A., L. Yuan, J. Hu in R. A. Cooke. 2016. »What Matters More? The Impact of Industry and Organizational Factors on Organizational Culture.«Management Decision 54 (3): 570-88.

Cooke, R.A., in J. C. Lafferty. 1987. Organizational Culture Inventory. Plymouth: Human Synergistics International.

Cooke, R. A., in J. L. Szumal. 1993. »Measuring Normative Beliefs and Shared Behavioral Expectations in Organizations: The Reliability and Validity of the Organizational Culture Inventory.« Psychological Reports 72 (3): 1299-330.

Deal, T. E., in A. A. Kennedy. 1982. Corporate Cultures: The Rites and Rituals of Corporate Life. Reading: Addison-Wesley.

Denison, D. R. 1990. Corporate Culture and Organizational Effectiveness. New York: Wiley.

Denison, D. R., in W. Neale. 2000. Denison Organizational Culture Survey. Ann Arbor, MI: Denison Consulting.

Denison, D. R., S. Haaland in P. Goelzer. 2003. »Corporate Culture and Organizational Effectiveness: Is There a Similar Pattern around the World? « Advances in Global Leadership 3 (2): 205-27.

Denison, D. R., L. Nieminen in L. Kotrba. 201 2. »Diagnosing Organizational Cultures: A Conceptual and Empirical Review of Culture Effectiveness Surveys.« European Journal of Work and Organizational Psycho$\log 223$ (I): 145-6I.

Ehrhart, M. G., B. Schneider in W. H. Macey. 2014. Organizational Climate and Culture. New York: Routledge.

Fey, C., in D. R. Denison. 2003. »Organizational Culture and Effectiveness: Can an American Theory be Applied in Russia?« Organization Science I 4 (6): 686-706.

Fleishman, E. A. 1953. »Leadership Climate, Human Relations Training and Supervisory Behavior.« Personnel Psychology 6 (2): 205-22.

Flynn, F. J., in J. A. Chatman. 200I. »Strong Cultures and Innovation: Oxymoron or Opportunity? «V The international handbook of organizational culture and climate, ur. C. L. Cooper, S. Cartwright in P. C. Earley, 263-87. New York: Wiley. 
Gardner, B. 1945. Human Relations in Industry. Homewood: Irwin.

Gilmer, B. H. 196r. Industrial Psychology. New York: McGraw-Hill.

Gilmer, B. H. 1966. Industrial Psychology, $2^{\text {nd }}$ ed. New York: McGraw-Hill.

Giorgi, S., C. Lockwood in A. M. Glynn. 2015. »The Many Faces of Culture: Making Sense of 30 Years of Research on Culture in Organization Studies.« The Academy of Management Annals 9 (19): I-54.

Gorenc, I., D. Mesner-Andolšek, B. Kavčič, A. Čibron-Kodrin in D. Deškovič. 1987. »Poročilo o delu za leto I987: URP/RP.« Ljubljana: RI FSPN.

Griffin, R. W., in G. Moorhead. 2014. Organizational Behavior: Managing People and Organizations. New York: McGraw-Hill.

Heron, J., in P. Reason. 2006. »The Practice of Co-Operative Inquiry: Research 'with' Rather than 'on' People.«V Handbook of Action Research, ur. P. Reason in H. Bradbury, I79-88. Thousand Oaks: Sage.

Hitt, M. A., C. C. Miller in A. Colella. 2or r. Organizational Behavior. Hoboken: John Wiley \& sons.

Hofstede, G. 1980. Culture's Consequences: International Differences in Work-Related Values. Beverly Hills: Sage.

Jaques, E. 1951. The Changing Culture of a Factory. New York: Dryden Press.

Kasper, H. 1987. Organisationskultur. Wien: Service, Fachverlag an der Wirtschaftsuniversität.

Kavčič, B. 1988. »Nova organizacijska paradigma.« Organizacija in kadri 2I (3/4): 193-205.

Konrad, E. 1990. »Organizacijska kultura in prilagajanje: spremembam v poslovanju.« MM media marketing Io (I05): I2-I 4 .

Kotrba, L. M., M. A. Gillespie, A. M. Schmidt, R. E. Smerek, S. A. Ritchie in D. R. Denison. 201 2. »Do Consistent Corporate Cultures Have Better Business Performance? Exploring the Interaction Effects. $\ll$ Human Relations 65 (2): 24I-62.

Kotter, J. P., in J. L. Heskett. 1992. Corporate Culture and Performance. New York: The Free Press.

Kouzes, J. M., D. F. Caldwell in B. Z. Posner. 1983. »Organizational Culture: How It Is Created, Maintained, and Changed.« Prispevek predstavljen na OD Network National Conference, Los Angeles, California.

Kovač, J. I990. »Dejavniki uspešne uresničitve strategije podjetja.«Organizacija in kadri 23 (7-8): 54I-54.

Lee, S. K. J., in K. Yu. 2004. »Corporate Culture and Organizational Performance.« Journal of Managerial Psychology I9 (3): 340-59. 
Martin, J. 2002. Organizational Culture: Mapping the Terrain. Thousand Oaks: Sage.

Martin, J., P. J. Frost in O. A. O’Neill. 2006. »Organizational Culture: Beyond Struggles for Intellectual Dominance.« V Sage Handbook of Organizational Studies, $2^{\text {nd }}$ ed., ur. S. Clegg, C. Hardy, T. Lawrence in W. Nord, 725-53. Thousand Oaks: Sage.

Meek, L. V. 1988. »Organizational Culture: Origins and Weaknesses.«Organizational Studies (9) 4: 453-73.

Mesner-Andolšek, D. 1988. Organizacijska kultura in stil vodenja. Ljubljana: Gospodarski vestnik: delavska enotnost.

Mesner-Andolšek, D. 1992. Vpliv kulture na organizacvijsko strukturo. Ljubljana: FDV.

Meško Štok, Z., M. Markič, A. Bertoncelj in M. Meško. 2010. »Elements of Organizational Culture Leading to Business Excellence $=$ Elementi organizacijske kulture koji vode do poslovne izvrsnosti.« Zbornik radova Ekonomskog fakulteta u Rijeci 28 (2): 303-18.

Moretti, M., in R. Biloslavo. 20I I. »Pomen marketinške kulture za ugled podjetja.«Organizacija: revija za management, informatiko in kadre 44 (5): 168-79.

Mullins, L. J. 2010. Management \& Organisational Behaviour. Edinburg: Pearson Education Limited.

Murphy, P. J., R. A. Cooke in Y. Lopez. 2013. »Firm Culture and Performance: Intensity's Effects and Limits.« Management Decision 5 I (3): 66I-79.

Nylund, K. L., T. Asparouhov in B. Muthén. 2007. »Deciding on the Number of Classes in Latent Class Analysis and Growth Mixture Modeling: A Monte Carlo Simulation Study.« Structural Equation Modeling: A Multidisciplinary Journal i 4 (4): 535-69.

O'Reilly, C. 1983. »Corporations, Cults, and Organizational Culture: Lessons from Silicon Valley Firms.« Prispevek predstavljen na Annual Meeting of the Academy of Management, Dallas, Texas.

Ott, J. S. 1989. The Organizational Culture Perspective. Pacific Grove: Brooks-Cole.

Ouchi, W. G. 1981. Theory Z: How American Business Can Meet the Japanese Challenge. Reading: Addison-Wesley.

Pascale, R., in A. Athos. 1982. The Art of Japanese Management. London: Penguin. 
Peters, T. J., in R. H. Jr. Waterman. 1982. In Search of Excellence . New York: Harper \& Row.

Pettigrew, A. M. 1979. »On Studying Organizational Cultures.«Administrative Science Quarterly 24 (4): 570-8I.

Potočan, V., L. Galetić, S. Rašič, A. Aleksić, T. Filipović, M. Kindžić in I. Načinović Braje. 2016. Organizacija. Zagreb: Sinergija.

Quinn, R. E., in J. Rohrbaugh. 1983. »A Special Model of Effectiveness Criteria: Toward a Competing Values Approach to Organizational Analysis.« Management Science 29 (3): 363-77.

Robbins, S. P., in T. A. Judge. 2013. Organizational Behavior. Upper Saddle River: Pearson Prentice Hall.

Roethlisberger, F. J., in W. J. Dickson. 1939. Management and the Worker. Boston: Harvard School.

Ropar, I., in M. Moretti. 20I4. »Dejavniki marketinške kulture in zadovoljstvo udeležencev organizacij.« Journal of Innovative Business and Management 6 (I-2): I2-25.

Sathe, V. 1985. Culture and Related Corporate Realities. Homewood: Irwin.

Schein, E. H. 1985. Organizational Culture and Leadership. San Francisco: Jossey-Bass.

Schein, E. H. 2010. Organizational Culture and Leadership. San Francisco: Jossey-Bass.

Schermerhorn, J. R. 2013. Introduction to Management. Hoboken: Wiley.

Sikorski, C. 1986. »Organizacijska kultura in njene motivacijske in sistemske determinante.«Organizacija in kadri 19 (I/2): 4-II.

Sørensen, J. B. 2002. »The Strength of Corporate Culture and the Reliability of Firm Performance.« Administrative Science Quarterly 47 (I): $70-$ 9 I.

Spencer, J. C. 1983. »Myths, Recipes and Knowledge-Bases in Organizational Analysis.« Neobljavljen rorkopis, Graduate School of Management, University of California at Los Angeles.

Šarotar Žižek, S., S. Treven in M. Mulej. 2015. Model psibičnega dobrega pocuutja zaposlenih na temelju zadostne in potrebne osebne celovitosti za krepitev uspešnosti. Maribor: IRDO, Inštitut za razvoj družbene odgovornosti.

Tekavčič, M., Dimovski, D., Peljhan, D., Škerlavaj, M. 20ı . Cultural differences and homogeneity in strategic alliances : the case of Trimo Trebnje. Cheltenham; Northampton: E. Elgar, cop. 
Tsui, A. S., Z-X. Zhang, H. Wang, K. R. Xin in J. B. Wu. 2006. »Unpacking the Relationship between CEO Leadership Behavior And Organizational Culture.«Leadership Quarterly 17 (2): I I3-37.

Turner, B. 197 I. Exploring the Industrial Subculture. London: Macmillan.

Van Maanen, J., in S. R. Barley. 1983. »Cultural Organization: Fragments of a Theory.« Paper presented at the Annual Meeting of the Academy of Management, Dallas, Texas.

Van Maanen, J., in S. R. Barley. 1985. »Cultural Organization: Fragments of a Theory.«V Organizational culture, ur. P. J. Frost, L. F. Moore, M. R. Louis, C. C. Lundberg in J. Martin, 3 I-54. Beverly Hills: Sage.

Verbeke, W., M. Volgering in M. Hessels. 1998. »Exploring the Conceptual Expansion within the Field of Organizational Behaviour: Organizational Climate and Organizational Culture.«Journal of Management Studies 35 (3): 303-29.

Whyte, W. F. 1943. Street Corner Society. Chicago: University of Chicago Press.

Whyte, W. F. 1948. Human Relations in the Restaurant Industry. New York: McGraw-Hill.

Xenikou, A., in A. Furnham. 1996. »A Correlational and Factor Analytic Study of Four Questionnaire Measures of Organizational Culture.« Human Relations 49 (4): 349-7I.

Xenikou, A. in M. Simoni. 2006. »Organizational Culture and Transformational Leadership as Predictors of Business Unit Performance.«Journal of Managerial Psychology 2 I (6): 566-79. 



\title{
2 \\ Nastanek (oblikovanje), \\ obstoj (socializacija), revizija \\ in spreminjanje organizacijske kulture
}

\author{
Melita Moretti
}

\section{Nastanek (oblikovanje) organizacijske kulture}

Prvotna organizacijska kultura izhaja iz filozofije ustanoviteljev in močno vpliva na način, kako organizacija raste in se razvija. Zaradi edinstvene vloge pri ustanovitvi organizacije imajo ustanovitelji močan vpliv na oblikovanje začetne organizacijske kulture. Z leti delovanja organizacije se vpliv ustanoviteljev zmanjšuje predvsem zaradi upokojitve ali odpovedi neposrednega nadzora ustanoviteljev nad organizacijo (Ott 1989; Alvesson in Sveningsson 2008; Alvesson in Sveningsson 2016). Po mnenju Scheina (2010) ustanovitelji organizacije svoje vrednote in prepričanja sporočajo preko posameznih primarnih (na kaj naj bodo managerji pozorni, kako naj delujejo in kako naj nadzorujejo, kako naj se odzovejo na krizno situacijo, kako razporejajo vire ipd.) in sekundarnih (vpliv na organizacijsko strukturo in strukturo organiziranosti, organizacijske sisteme in postopke ipd.) mehanizmov vpliva - glej preglednico 2.I.

Čeprav ustanovitelji preko lastnih vrednot in prepričanj vplivajo na organizacijsko kulturo na način, da oblikujejo predloge za razrešitev nastalih težav in problemov v organizaciji, te razrešitve niso sprejete $\gg$ na slepo« - predlagane rešitve naj bi sprejeli tako managerji kot tudi večina ostalih zaposlenih sodelavcev v organizaciji (Schein 1983).

Na nastanek in oblikovanje organizacijske kulture vplivata tudi skupno učenje članov organizacije in utrjevalni proces, ki poteka dalj časa. Učni proces pripadnikov organizacije Schein (1983, 20I0) deli na: (I) vidike, ki obravnavajo probleme zunanjega prilagajanja, in (2) vidike, ki obravnavajo težave, povezane z notranjo integracijo. Vidiki, s katerimi se obravnavajo problemi zunanjega prilagajanja, so v bistvu vprašanja, zakaj 
organizacija obstaja, kaj so njeni smotri in cilji in kaj naj bi v organizaciji naredili za njen nadaljnji obstoj. Vidiki, s katerimi se obravnavajo težave, povezane $z$ notranjo integracijo, pa so v bistvu vprašanja, kako skupina pri razreševanju problemov zunanjega prilagajanja sodeluje in funkcioni$\mathrm{ra}-\mathrm{v}$ skupini naj bi pri razreševanju problemov zunanjega prilagajanja razvili skupen jezik, skupno razumevanje glede moči in statusa ter poiskali soglasje o tem, kakšno je učinkovito in neučinkovito vedenje posameznikov v organizaciji.

Preglednica 2.r: Mehanizmi vpliva ustanoviteljev organizacije na organizacijsko kulturo

Primarni vpliv ustanoviteljev organizacije

Na kaj naj bodo managerji pozorni, kako naj ravnajo in kako naj nadzorujejo

Kako se managerji odzovejo na krizno situacijo

Kako managerji razdelijo vire

Kako v organizaciji poteka izobraževanje in usposabljanje zaposlenih

Kako managerji dodeljujejo nagrade in statusne položaje (pozicijo)

Na kakšen način managerji izbirajo, zaposlujejo ali odslovijo posameznega sodelavca

\section{Sekundarni vpliv in utrditev vpliva ustanoviteljev organizacije}

Vpliv na organizacijsko obliko in strukturo organiziranosti

Vpliv na organizacijske sisteme in postopke

Vpliv na obrede in rituale v organizaciji

Vpliv na oblikovanje zunanjega izgled kot npr. poslovnih prostorov, stavb, fasad ipd.

Vpliv na zgodbe o pomembnih dogodkih in pomembnih posameznikih

Vpliv na formalne izjave o filozofiji organizacije

Vir: Schein 2010, 236.

$\mathrm{Na}$ nastanek in oblikovanje organizacijske kulture vpliva tudi gospodarsko in družbeno okolje organizacije, predvsem vpliv širše kulture družbe, $v$ kateri organizacija deluje (Hofstede in Peterson 2000; Brodbeck idr. 2004; Aldrich in Ruef 2006; Nazarian, Atkinson in Greaves 2014; Nazarian, Atkinson in Foroudi 2017). Iz raziskava Hofsteda in Petersona (2000) je razvidno, da so v organizacijah, ki delujejo v več državah, razvili tako skupno organizacijsko kulturo kot edinstvene subkulture v vsaki državi, te subkulture pa so usklajene $\mathrm{z}$ nacionalno kulturo te države. Tudi iz raziskave Brodbecka idr. (2004) med 62 nacionalnimi kulturami je razvidno, da je mogoče z nacionalno kulturo pojasniti med $2 \mathrm{I}$ in $47 \%$ variance dimenzij organizacijske kulture. Poleg družbene (naci- 
onalne) kulture na posamezno organizacijsko kulture vpliva tudi dejavnost, $\mathrm{v}$ kateri organizacija deluje (Devine idr. 2007; Nazarian, Atkinson in Foroudi 2017). Deal in Kennedy (1982) sta dejavnost, v kateri organizacija deluje, opisala ko »en sam največji vpliv na oblikovanje organizacijske kulture « (Deal in Kennedy 1982, I3). Ott (1989) med razloge, zakaj dejavnost organizacije vpliva na organizacijsko kulturo in zakaj imajo organizacije $v$ nekaterih dejavnostih podobno kulturo, prišteva naslednje:

- v dejavnosti, v kateri organizacija deluje, obstajajo prevladujoči poklici posameznikov, katerih lastnosti in značilnosti si deli tudi večina zaposlenih $\mathrm{v}$ organizaciji,

- organizacija je v interakciji z zunanjimi udeleženci (npr. dobavitelji, kupci, potrošniki, odjemalci, finančne institucije, lokalna in državna infrastruktura ipd. ); značilnost kupcev in njihovih zahtev oblikuje takšno organizacijsko kulturo, da ta vpliva na uspešnost podjetja ali druge ustanove,

- na razvoj organizacijske kulture vplivata tveganje in hitrost informacij: $v$ monopolnih organizacijah npr. razvijejo drugačno organizacijsko kulturo kot $\mathrm{v}$ organizacijah $\mathrm{z}$ veliko konkurenti (tveganje), v organizacijah, ki prodajajo proizvode preko svetovnega spleta (pomembna je hitrost informacij), razvijejo drugačno organizacijsko kulturo kot $\mathrm{v}$ organizacijah $\mathrm{v}$ naftni ali vesoljski dejavnosti ipd.,

- zgodovinski razvoj dejavnosti, njene prevladujoče tehnologije in hitrost sprememb v dejavnosti.

\section{Obstoj (socializacija) organizacijske kulture}

Ne glede na to, kakšna organizacijska kultura obstaja, jo je zaradi uporabnosti in njenega obstoja $\mathrm{v}$ daljšem časovnem obdobju treba $\gg$ prenesti $\ll$ na novozaposlene, jo socializirati. Socializacijo organizacijske kulture opredelimo kot postopek, na osnovi katerega udeleženci v organizaciji pridobijo vrednote, norme, prepričanja, predpostavke in zahtevana vedenja, ki jim omogočajo biti učinkovit in pomemben član organizacije (Griffin in Moorhead 20I4). V organizaciji je socializacija lažja naloga, saj se začne že v izbirnem postopku ( $v$ fazi izbiranja posameznikov), ko zaposlitev ne sklenejo $s$ tistim posameznikom, ki ne ustreza njihovi organizacijski kulturi (Hitt, Miller in Colella 201 I; Robbins in Judge 2013).

Beres in Portwood (1979) sta organizacijsko kulturo opredelila kot »kognitivni referenčni okvir in vzorec vedenja, ki se iz prejšnjih članov organizacije prenaša na nove člane organizacije « (Beres in Portwood 
1979, 171). Tudi Shein (2010) meni, da z organizacijsko kulturo »učimo nove člane pravilnega načina dojemanja, razmišljanja in čutenja « (Schein 2010, I8).

Ashforth, Sluss in Harrison (2007) model socializacije razdelijo na štiri faze, in sicer na: predvidevanje/pričakovanje, srečanje, prilagajanje in stabilizacijo. Prva faza (predvidevanje/pričakovanje) se začne pred vstopom posameznika $\mathrm{v}$ organizacijo in vključuje pričakovanja posameznika o organizaciji, ki jih pridobi na osnovi informacij, ki jih organizacija sporoča navzven (v zunanje družbeno okolje). Druga faza (srečanje) obravnava vstop posameznika $\mathrm{v}$ organizacijo, kjer posameznik primerja svoja lastna pričakovanja iz prve faze z izkušnjami, ki jih je pridobil v organizaciji. $V$ tej fazi lahko pride do čustvenih reakcij posameznika na podlagi izpolnjenih ali neizpolnjenih pričakovanj. $\mathrm{V}$ tretji fazi (prilagajanje) gre posameznik skozi proces prilagajanja in postane integriran $\mathrm{v}$ organizacijo. Faza prilagajanja vključuje lastna prizadevanja posameznika, da se integrira $\mathrm{v}$ organizacijo, kot tudi prizadevanja organizacije $\mathrm{v}$ procesu njegove socializacije (npr. usposabljanje, mentorstvo ipd.). V zadnji fazi (stabilizacija) posameznik z vidika socializacije postane polnopravni član organizacije.

Proces socializacije

Izidi

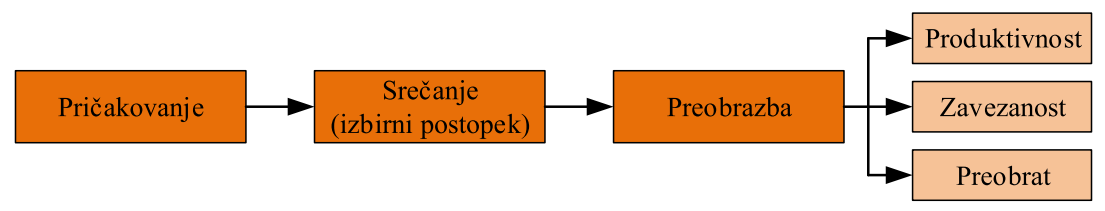

Slika 2.r: Proces socializacije

Vir: Robbins in Judge 2013,255.

Robbins in Judge (2013) proces socializacije razdelita na tri faze, in sicer pričakovanje, srečanje in preobrazba (slika 2.I). Prva faza (pričakovanje) se začne pred vstopom posameznika v organizacijo in vključuje pričakovanja posameznika o organizaciji, ki jih oblikuje na osnovi informacij, ki jih v organizaciji sporočajo navzven. $\mathrm{V}$ drugi fazi (srečanje) se posameznik, ki je vstopil v organizacijo, sooča npr. s pričakovanji o delovnem mestu, sodelavcih, neposredno nadrejenem ipd. Ta pričakovanja se lahko razlikujejo od resničnosti. Zato je izbira pravega posameznika pri izbirnem postopku zelo pomembna. $V$ tretji, zadnji fazi (preobrazba) gre posameznik skozi preobrazbo preko formalnih, neformalnih, kolektivnih in/ 
ali serijskih programov socializacije. Ko se proces socializacije na novo zaposlenega posameznika konča, vpliva na produktivnost novozaposlenega, na zavezanost smotrom in ciljem organizacije ter morebitno odločitev, da v organizaciji ostane.

\section{Revizija organizacijske kulture in njeno spreminjanje}

Za učinkovito obvladovanje podjetja ali druge ustanove naj bi managerji redno spremljali trenutno organizacijsko kulturo (npr. analizirali skupne vrednote in prepričanja v organizaciji ipd.). Hitt, Miller in Colella (20I I) predlagajo naslednje korake spremljanja organizacijske kulture:

- prvi korak: analizirati procese in vsebine socializacije novih sodelavcev in managerjev (z izvedbo intervjujev),

- drugi korak: analizirati odzive na kritične dogodke v preteklosti organizacije (npr. na podlagi dokumentov in intervjujev preteklih ter sedanjih sodelavcev in managerjev izdelati biografijo organizacije),

- tretji korak: analizirati vrednote in prepričanja »ustvarjalcev« organizacijske kulture (ustanoviteljev) in sedanjih managerjev (z opazovanjem in/ali izvedbo intervjujev ustanoviteljev in sedanjih managerjev),

- četrti korak: poiskati odstopanja in nepravilnosti ter s sedanjimi managerji sprožiti postopke razreševanja teh odstopanj in nepravilnosti,

- peti korak: po izvedbi četrtega koraka izvesti pregled povezanosti sedanje organizacijske kulture s smotri in cilji organizacije.

Revizija organizacijske kulture naj bi bila kompleksen in dolgotrajen proces, ki ga je treba izvesti po skrbnem načrtovanju, saj lahko rezultati revizije pokažejo, da organizacijska kultura ni dobro razvita. Revizija lahko tudi odkrije prisotnost subkultur (subkulture so v smislu organizacije skupine posameznikov v organizaciji, ki si delijo vrednote, drugačne od glavnih vrednot organizacije), ki se močno razlikujejo od glavnih vrednot organizacije.

Sprememba organizacijske kulture naj bi bil dolg in zapleten proces. $\mathrm{V}$ primeru, ko stari veljavni postopki za doseganje uspešnosti niso več zadostni, ko v organizaciji niso zmožni razločevati med konkurenčnii alternativami in možnostmi, ko začnejo $\mathrm{v}$ organizaciji prisiljeno ponavljati prejšnje (prej uspešne, toda sedaj že preživele) aktivnosti delovanja, ko za razeševanje težav v poslovanju potrebujejo veliko časa, virov in naporov (npr. odločajo za spremembe in reorganiziranje organzacijske eno- 
te, programov, spreminjajo kadrovsko politiko ipd.), ki niso pravi, organizacijska kultura postane neustrezna in jo je treba spremeniti (Robbins in Judge 2013; Schermerhorn in Wright 2014). Sprememba organizacijske kulture je potrebna, ko se v organizacijah soočajo s preživetjem ali pa zaradi številnih drugih zunanjih in notranjih sprememb (npr. tehnoloških sprememb, novih konkurentov, novih materialov, sprememb v političnem sistemu ipd.). Po mnenju Armstronga (2009) sta prav izboljševanje in spreminjanje organizacijske kulture pomembna dejavnika za njeno preživetje. Po mnenju Ehrharta, Schneiderja in Maceya (2014) naj bi bilo organizacijsko kulturo težko spremeniti, ker:

- vsebuje globoka prepričanja in predpostavke,

- vsebuje veliko število soodvisnih dejavnikov/sestavin,

- je samoumevna, o njej se redko razpravlja,

- je globoko povezana z zgodovino organizacije,

- so vprašanja v zvezi z organizacijsko kulturo povezana s kulturo moči ali statusom $v$ organizaciji,

- imajo v organizaciji le redko enotno organizacijsko kulturo, v njej obstaja več subkultur,

- je organizacijska kultura povezana z različnimi notranjimi in zunajnimi dejavniki.

Primarni problem pri spreminjanju organizacijske kulture Griffin in Moorhead (2014) prepoznata v vršnih managerjih, ki kljub predanosti spremembam organizacijske kulture nehote prevzemajo ustaljene vzorce vedenja in obnašanja. Za lažje spreminjanje organizacijske kulture je $\mathrm{v}$ večini primerov najboljša menjava vršnih managerjev. Prav tako se zaposleni v organizaciji upirajo vsakršnim spremembam, bodisi zaradi neobveščenosti bodisi zaradi slabe obveščenosti o spremembah (Huczynski in Buchanan 2013; Alvesson in Sveningsson 2016). Poudariti velja tudi, da je šibko organizacijsko kulturo lažje spreminjati kot močno, saj je krog privrženosti njej ožji in soglasje o vrednotah manjše. Prav tako je lažje spreminjati organizacijsko kulturo $\mathrm{v}$ mladi in majhni organizaciji, kjer vrednote še niso tako zakoreninjene in kjer je članov organizacije malo, managerji pa tako lažje sporočijo nove vrednote. Procesi spreminjanja organizacijske kulture se začnejo $s$ potrebo po spremembi in premikom $\mathrm{v}$ prehodnem obdobju, v katerem so vloženi veliki napori za sprejemanje novih vrednot in prepričanj. $\mathrm{Na}$ dolgi rok bodo uspešno spremenili svojo organizacijsko kulturo in ugotovili, da so nove vrednote in prepričanja prav tako stabilni in vplivajo na izide organizacije kot stare vrednote in prepričanja - nove vrednote in prepričanja bodo verjetno ostali v veljavi 
dolgo časa (Schabracq 2007; Alvesson in Sveningsson 2008; Alvesson in Sveningsson 2016).

Modelov spreminjanja organizacijske kulture je veliko, saj se je s tem vprašanjem ukvarjalo veliko avtorjev, kot so Schein, Cameron in Quinn, Lewin, Kotter in drugi.

Scheinov (2010) model spreminjanja organizacijske kulture temelji na predpostavki, da se organizacijska kultura spreminja glede na življenjski cikel organizacije (ustanovitev/rojstvo in rast organizacije, srednje obdobje organizacije, obdobje zrelosti in upadanje ter ukinitev oziroma prenehanje organizacije). Organizacijska kultura se v obdobju rojstva in zgodnje rasti spreminja s pomočjo naravne evolucije (npr. spremembe zaradi povečanja števila zaposlenih, diferenciacije, integracije), namerno vodene evolucije $\mathrm{z}$ organizacijsko terapijo (spremembe zaradi prihoda zunanjih svetovalcev), $z$ vodeno evolucijo s pomočjo hibridov (spremembe zaradi zamenjave managerjev - na vodilne položaje pridejo že zaposleni v organizaciji) in $\mathrm{z} \gg$ revolucijo $\ll$, vodeno $s$ pomočjo zunanjih dejavnikov (spremembe zaradi zamenjave managerjev - na vodilne položaje pridejo novi managerji od zunaj). Organizacijska kultura se v srednjem obdobju spreminja npr. z načrtnimi spremembami, uvajanjem novih tehnologij, sprememb, uporabo škandalov, s porušitvijo mitov ipd. V obdobju zrelosti se spreminja npr. z nasilnim prepričevanjem, prenovo organizacije, reorganizacijo in destrukcijo ipd.

Model spreminjanja organizacijske kulture po Cameronu in Quinnu (2006; 20I I) je sestavljen iz šestih korakov načrtnega in dejanskega uvajanja sprememb, in sicer:

I. doseganja soglasja o sedanji/trenutni organizacijski kulturi,

2. doseganja soglasja o zaželeni organizacijski kulturi,

3. ugotovitve, kaj je potrebno spremeniti in kaj ne,

4. določitve usmeritvene zgodbe za sporočanje organizacijske kulture,

5. izdelave strateškega načrta spreminjanja organizacijske kulture,

6. razvoja načrta uresničevanja sprememb organizacijske kulture.

Lewinov model spreminjanja je preprost model spreminjanja organizacijske kulture in sestoji iz treh zaporednih stopenj: odmrznitve, uvajanja sprememb, zamrznitve (Schein 2010; Robbins in Judge 2013).

Model spreminjanja organizacijske kulture je po Kotterju sestavljen iz osmih korakov načrtnega uvajanja sprememb, in sicer (Robbins in Judge 2013):

I. ugotoviti pravi razlog nujnosti sprememb organizacijske kulture, 
2. oblikovati skupino $z$ dovolj moči za načrtovanje, vodenje in obvladovanje sprememb,

3. ustvariti novo vizijo za usmerjanje sprememb in oblikovati strategije za njeno uresničitev,

4. sporočati (komuniciranje) ostalim v organizaciji o novi viziji organizacije,

5. pooblastiti druge zaposlene, da sodelujejo pri odpravi ovir za spremembo organizacijske kulture, spodbujati tveganje in kreativno razreševanje problemov,

6. načrtovati, ustvarjati in nagrajevati kratkoročne $\gg$ zmage $\ll, k i$ organizacijo premikajov smer nove vizije,

7. utrditi izboljšave, ponovno oceniti spremembe in izvesti nujne prilagoditve,

8. okrepiti spremembe v organizacijski kulturi, ki se kažejo z novim vedenjem in obnašanjem ter drugimi izidi iz organizacije.

\section{Povzetek poglavja}

Poglavje opisuje nastanek in oblikovanje organizacijske kulture, socializacijo, revizijo in njeno spreminjanje. Na nastanek in oblikovanje organizacijske kulture vplivajo: ustanovitelji organizacije, skupno učenje udeležencev organizacije in utrjevalni proces, ki poteka $\mathrm{v}$ daljšem časovnem obdobju, kultura širšega družbenega okolja (npr. v organizacijah, ki delujejo v več državah, so razvili tako skupno organizacijsko kulturo kot edinstveno subkulturo v vsaki državi, te subkulture pa so uskladili z nacionalno kulturo države) in dejavnost, v kateri organizacija deluje.

Ne glede na to, kakšna organizacijska kultura obstaja, jo je zaradi uporabnosti in njenega obstoja $\mathrm{v}$ daljšem časovnem obdobju treba $\gg$ prenesti « na novozaposlene, jo socializirati. Pod pojmom »socializacija novih udeležencev v organizaciji« razumemo postopke, na osnovi katerih se npr. vrednote, norme, prepričanja, predpostavke in zahtevana vedenja ipd. prenašajo s prejšnjih ter sedanjih udeležencev na nove udeležence.

Trenutno organizacijsko kulturo naj bi managerji redno spremljali (izvajali t. i. revizijo organizacijske kulture) z namenom trajnostnega razvoja organizacije, boljšega obvladovanja ter zaradi njenega učinkovitejšega doseganja smotrov in ciljev. Revizija orgnizacijske kulture naj bi bil kompleksen in dolgotrajen proces, ki naj bi ga izvedli šele po skrbnem načrtovanju, saj rezultati revizije lahko pokažejo, da organizacijska kultura ni dobro razvita ali pa $\mathrm{z}$ revizijo odkrijemo prisotnost subkultur, ki se 
močno razlikujejo od glavnih vrednot $\mathrm{v}$ organizaciji. $\mathrm{V}$ tem primeru je treba organizacijsko kulturo spremeniti.

Sprememba organizacijske kulture naj bi bil dolg in zapleten proces, saj je takšna kultura globoko zasidrana $\mathrm{v}$ zasnovo organizacije. Za lažje spreminjanje organizacijske kulture je tako v večini primerov najboljša menjava vršnih managerjev. Procesi spreminjanja organizacijske kulture se začnejo s potrebo po spremembi in premikom $\mathrm{v}$ prehodnem obdobju, $\mathrm{v}$ katerem so vloženi veliki napori za sprejemanje novih vrednot in prepričanj, dolgoročno pa bo organizacijska kultura stabilna, če bo pozitivno vplivala na izide organizacije.

\section{Literatura}

Aldrich, H. E., in M. Ruef. 2006. Organizations Evolving. Thousand Oaks: Sage.

Alvesson, M., in S. Sveningsson. 2008. Changing Organizational Culture Cultural Change Work in Progress. New York: Routledge.

Alvesson, M., in S. Sveningsson. 2016. Changing Organizational CultureCultural Change Work in Progress. New York: Routledge.

Armstrong, M. 2009. Armstrong's Handbook of Human Resource Management Practice. London: Kogan Page.

Ashforth, B. E., D. M. Sluss in S. H. Harrison. 2007. »Socialization in Organizational Contexts.« V International Review of Industrial and Organizational Psychology, ur. G. P. Hodgkinson in J. K. Ford: I-70. Sussex: Wiley.

Beres, M. E., in J. D. Portwood. 1979. »Explaining Cultural Differences in the Perceived Role of Work: An Intranational Cross-Cultural Study.« V Organizational Functioning in a Crosscultural Perspective, ur. G. W. England, A. R. Negandhi in B. Wilpert, 139-73. Kent: Kent State University Press.

Brodbeck, F. C., P. J. Hanges, M. W. Dickson, V. Gupta in P. W. Dorfman. 2004. »Societal Culture and Industrial Sector Influences on Organizational Culture.«V Culture, Leadership, and Organizations: The GLOBE Study of 62 Societies, ur. R. J. House, P. J. Hanges, M. Javidan, P. W. Dorfman in V. Gupta, 654-68. Thousand Oaks: Sage.

Cameron, K. S., in R. E. Quinn. 2006. Diagnosing and Changing Organizational Culture. San Francisco: Jossey-Bass.

Cameron, K. S., in R. E. Quinn. 201 I. Diagnosing and Changing Organizational Culture: Based on the Competing Values Framework. San Francisco: Wiley. 
Deal, T. E., in A. A. Kennedy. 1982. Corporate Cultures: The Rites and Rituals of Corporate Life. Reading: Addison-Wesley.

Devine, F., T. Baum, N. Hearns in A. Devine. 2007. »International Journal of Contemporary Hospitality Management Managing Cultural Diversity: Opportunities and Challenges for Northern Ireland Hoteliers. « International Journal of Contemporary Hospitality Management I9 (2): $120-32$.

Ehrhart, M. G., B. Schneider in W. H. Macey. 2014. Organizational Climate and Culture. New York: Routledge.

Griffin, R. W., in G. Moorhead. 2014. Organizational Behavior: Managing People and Organizations. New York: McGraw-Hill.

Hitt, M. A., C. C. Miller in A. Colella. 2or r. Organizational Behavior. Hoboken: John Wiley \& Sons.

Hofstede, G., in M. F. Peterson. 2000. »Culture: National Values and Organizational Practices.«V Handbook of Organizational Culture and Climate, ur. N. M. Ashkanasy, C. P. M. Wilderom in M. F. Peterson, 40II4. Thousand Oaks: Sage.

Huczynski, A. A., in D. A. Buchanan. 2013. Organizational Behaviour. Edinburg: Pearson.

Nazarian, A., P. Atkinson in L. Greaves. 2014. »The Relationship between National Culture and Organisational Culture: Case of Medium and Large Size Organisations in Iran.« Macrotheme Review 3 (6): 66-78.

Nazarian, A., P. Atkinson in P. Foroudi. 2017. »Influence of National Culture and Balanced Organizational Culture on the Hotel Industry's Performance.« International Journal of Hospitality Management 63 (I): $22-32$.

Ott, J. S. 1989. The Organizational Culture Perspective. Pacific Grove:Brooks-Cole.

Robbins, S. P., in T. A. Judge. 2013. Organizational Behavior. Upper Saddle River: Pearson Prentice Hall.

Schabracq, M. J. 2007. Changing Organizational Culture. Hoboken: John Wiley \& Sons Ltd.

Schein, E. H. 1983. »The Role of the Founder in Creating Organizational Culture.«Organizational Dynamics I 2 (I): 13-28.

Schein, E. H. 2010. Organizational Culture and Leadership. San Francisco: Jossey-Bass.

Schermerhorn, J. R., in B. Wright. 201 4. Management, $2^{\text {nd }}$ ed. Hoboken: Wiley. 


\title{
3 \\ Organizacijska kultura in učinkovitost organizacije
}

\author{
Petra Setničar in Mirko Markič
}

Pojem uspešnosti ni lahko opredeliti, saj predstavlja vseobsežen konstrukt in je odvisen od vidika, s katerega ga preučujemo. Je raznolika lastnost, ki ima v praksi delovanja podjetij in drugih ustanov svoje značilnosti, kot je npr. skupni rezultat $\mathrm{v}$ uspešnosti poslovanja pridobitne ali nepridobitne organizacije. Če s svojim delovanjem dosežejo pričakovane izide za večino udeležencev v notranjem in zunanjem okolju, naj bi to pomenilo, da je organizacija uspešna. Dobro poslovodenje pridobitne organizacije ni možno brez meril, kazalnikov in standardov za npr. delno poslovno učinkovitost in celovito, vseobsežno uspešnost (Markič 2004). Uspešnost pridobitne organizacije je mogoče meriti z različnih vidikov, npr. s prevladujočimi finančnimi kazalniki (npr. donosnost naložbe, dodane vrednosti ipd.), finančnimi in procesnimi kazalniki (npr. s tržnim deležem, stopnjo doseganja postavljenih smotrov in ciljev, $\mathrm{z}$ vidika deležnikov, uspešnosti procesa odločanja, uspešnosti pri zagotavljanju surovin, ekoloških standardov), kazalniki celovite učinkovitosti (kot npr. ugled in podoba $\mathrm{v}$ javnosti, v zadnjem casu pa še družbena odgovornost, trajnostni razvoj ipd.) (Venkatraman in Ramanujam 1986); ali s finančnimi (npr. ROA, ROE, ROI, ROS ipd.) in nefinančnimi (npr. zadovoljstvo in zvestoba zaposlenih, kakovost proizvoda ali procesa, zadovoljstvo kupcev ipd.) (De Wall 2008) ter še s številnimi drugimi načini (Kavčič 2005). Kolenc, Markič in Miklavčič Šumanski (2007) ugotavljajo, da je »organizacijska kultura najbolj trajna in najtežje spremenljiva sestavina uspešnosti«; vidijo jo (prav tam) kot trajno spodbudo in usmerjevalni inštrument za doseganje smotrov in ciljev organizacije. Organizacijska kultura podpira ali ovira uveljavljanje strategij ter smotrov in ciljev organizacije; tako pomembno 
vpliva na obvladovanje organizacije pri doseganju zastavljenih smotrov in ciljev, s tem pa na uspešnost managerjev (Griffin in Moorhead 2014). Pomembno vpliva tudi na opredeljevanje temeljne politike organizacije (Tavčar 2006) oziroma normativnega managementa (Bleicher 1994).

Glede na moč in primernost organizacijske kulture za izvajanje politike organizacije se managerji lahko odločajo med več koncepti (Tavčar 2006, 48-49):

- ignorirajo organizacijsko kulturo, kar kratkoročno lajša urejanje posameznih zadev, dolgoročno pa zmanjšuje uspešnost organizacije,

- izkoriščajo organizacijsko kulturo: to prinaša kratkoročne koristi, na dolgi rok pa slabša izglede organizacije zaradi nasprotovanja udeležencev,

- uporabljajo organizacijsko kulturo: managerji spodbujajo in negujejo tiste vidike kultur, poslovnega in družbenega okolja, ki so pomembni za sprotno ali dolgoročnejšo uspešnost organizacije, - spreminjajo organizacijsko kulturo: to je zahtevno, dolgotrajno in tvegano početje, ki je bolj mogoče v lastni organizaciji kot v poslovnih okoljih te organizacije.

Kavčič $(2005,69)$ ugotavlja, da je najpogosteje obravnavan vidik povezanosti organizacijske kulture in uspešnosti, da močna organizacijska kultura omogoča učinkovitost, čeprav avtorji niso enotnega mišljenja, kaj močna organizacijska kultura je. Po njegovem (prav tam) gre za $\gg s k u p e k$ vrednot in prepričanj ter praktičnih postopkov delovanja, ki so skupni vsem managerjem $v$ organizaciji in tudi članom organizacije «.

O'Reilly in Chatman (1996) opredeljujeta močno organizacijsko kulturo kot niz norm in vrednot, ki si jih deli in jih močno podpira večina članov organizacije. Opredelitve značilnosti močne organizacijske kulture iz literature povzemata Gordon in DiTomaso (1992, 785-86):

- koherentnost: skupek med seboj povezanih in soodvisnih norm in vrednot,

- homogenost: člani organizacije so enotni glede najpomembnejših vrednot in norm,

- stabilnost: prevladujoče vrednote so relativno trajne in se malo spreminjajo,

- kongruentnost, konsistentnost: usklajenost norm in vrednot, ki si medsebojno ne nasprotujejo in enotno usmerjajo delovanje članov, 
- strnjenost: manjše število vrednot in norm je strnjenih okrog centralne vrednote,

- penetracija: skupne vrednote pomembno vplivajo na delovanje velike večine članov organizacije,

- internaliziranost kontrole: za močne organizacijske kulture sta značilna zelo velika prisotnost in vpliv skupnih vrednot zaposlenih, ki umerjajo njihovo dejavnost od znotraj, zato zunanja kontrola (managerjev, postopkov in pravil) ni potrebna.

$\mathrm{Z}$ močna organizacijsko kulturo naj bi ugodne učinke za uspešnost dosegali preko skupnih smotrov in ciljev, skupnih vrednot, visoke motivacije in navdušujočih razmer, kar omogoča internalizacijo kontrole pri članih organizacije. Zaposleni prostovoljno usmerjajo svojo dejavnost $\mathrm{v}$ doseganje organizacijskih smotrov in ciljev. Na ta način se zmanjša potreba po zunanji, birokratski kontroli. To omogoča enostavnejšo organizacijsko strukturo (npr. manj ravni organiziranosti, manj managerjev, večjo samostojnost zaposlenih ipd.). Vse to pa zmanjša stroške delovanja organizacije in poveča njeno učinkovitost (Kotter in Heskett 1992; Brown 1998). Močna organizacijska kultura ljudi povezuje in usmerja bolj kot formalne norme, npr. zakoni, predpisi, navodila (Griffin in Moorhead 2014). Schermerhorn, Hunt in Osborn (199i) ugotavljajo, da so edinstvene skupne vrednote lahko vir za močno identiteto organizacije, spodbujajo kolektivno zavzetost, ustvarjajo stabilen družbeni sistem in zmanjšujejo potrebe po formalnem in birokratskem obvladovanju. Po drugi strani pa lahko močna organizacijska kultura povzroči, da managerji prezrejo pomen sprememb $\mathrm{v}$ družbenem in poslovnem okolju, ker so preveč zaverovani v splošno usvojena prepričanja $\mathrm{v}$ organizaciji, to pa ovira spremembe v organizaciji. Deal in Kennedy (1999) sta raziskovala organizacijsko kulturo v 207 organizacijah in izmed njih izbrala 20 organizacij z najšibkejšo in 20 organizacij z najmočnejšo organizacijsko kulturo. Ugotovila sta (prav tam), da so imeli v organizacijah z močno organizacijsko kulturo v povprečju 5,7I-krat višji dobiček iz tekočega poslovanja in za 4,17krat višjo rentabilnost kapitala kot $\mathrm{v}$ organizacijah $\mathrm{s}$ šibko organizacijsko kulturo. Vrednost delnic v organizacijah z močno organizacijsko kulturo je zrasla za 3,63-krat v primerjavi s tistimi s šibko. Kavčič (2005) navaja, da naj bi bila močna organizacijska kultura tudi strateško ustrezna, da ima pozitivne učinke na uspešnost, kar pomeni, da ni dovolj samo močna organizacijska kultura, ampak naj bo ta organizacijska kultura tudi pravilno usmerjena, da pospešuje uspešnost. Kadar močna organizacijska kultura ni pravilno usmerjena, ima negativen vpliv na uspešnost organizacije. Sørensen (200I) na osnovi raziskave na vzorcu organizacij iz 
različnih dejavnosti ugotavlja, da so $\mathrm{v}$ organizacijah $\mathrm{z}$ močnejšo organizacijsko kulturo dolgoročno učinkovitejši v stabilnem poslovnem okolju, medtem ko v spremenljivem poslovnem okolju prednost močne organizacijske kulture izgine. Denison (1990) ugotavlja, da je dolgoročno uspešna organizacija, ki ima takšno organizacijsko kulturo, ki udeležence (še posebej pa poslovodstvo) usmerja $\mathrm{k}$ sprejemanju informacij iz gospodarskega in družbenega okolja in ustreznemu interpretiranju le-teh. Udeleženci $\mathrm{v}$ tej organizaciji naj bi vedeli, kaj spremembe v gospodarskem in družbenem okolju pomenijo za organizacijo in kakšne spremembe zahtevajo $v$ sami organizaciji. Ustvarjanje uspešne organizacijske kulture je zahtevna naloga managerjev, ki naj pri njenem uresničevanju upoštevajo organizacijsko preteklost in sedanjost ter predvidijo njeno prihodnost (Kavčič $201 \mathrm{I})$.

Dimovski in Penger (2008) ugotavljata, da je organizacijska kultura kritičnega pomena $v$ učeči se organizaciji. Menita (prav tam), da je v učečih se organizacijah treba spodbujati prilagodljivo organizacijsko kulturo, $s$ katero se spodbuja odprtost, enakost, sodelovanje in izmenjavo znanja, izboljšave in spremembe, saj bo to prispevalo $k$ uspešnosti take organizacije. Ugotavljata (prav tam), da je rigidna organizacijska kultura za mnoge organizacije lahko nevarna, saj kulturne vrednote in prakse, ki prispevajo $\mathrm{k}$ uspehu v stabilnem poslovnem okolju, lahko škodujejo uspešnosti v hitro spreminjajočem se družbenem okolju. Uspešnost spodbujajoča organizacijska kultura se razvije tako, da ustanovitelj ustanovi organizacijo z adaptivno organizacijsko kulturo, ki ceni udeležence in spodbuja vodenje na vseh ravneh organiziranosti, ob tem pa razvije tako poslovno strategijo, ki ustreza gospodarskemu okolju in prinese uspeh. Posledično ustanovitelja in njegovo organizacijsko kulturo zaposleni cenijo ter sprejmejo to organizacijsko kulturo in njene temeljne domneve in vrednote. Sčasoma lahko pride do problema, kako tako organizacijsko kulturo trajneje ohraniti, da se ne izrodi v neuspešno. $V$ takem primeru je potreben manager, ki ustvari občutek krize in potrebe po spremembah. Oblikuje novo smer razvoja, ki vključuje oblikovanje nove adaptivne organizacijske kulture in ustrezne poslovne strategije (Brown 1998).

\section{Povzetek poglavja}

Organizacijska kultura vpliva na opredeljevanje temeljne politike organizacije, uveljavljanje strategij ter doseganje zastavljenih smotrov in ciljev podjetja ali druge ustanove. $\mathrm{Z}$ močno organizacijsko kulturo naj bi ugodne učinke za uspešnost dosegali preko skupnih smotrov in ciljev, skupnih vrednot in etike, visoke motivacije in navdušujočih razmer, kar pri udele- 
žencih organizacije omogoča internalizacijo kontrole. Zaposleni prostovoljno usmerjajo svojo dejavnost $\mathrm{v}$ doseganje organizacijskih smotrov in ciljev. Na ta način se zmanjša potreba po zunanji, birokratski kontroli in omogoča enostavnejša organizacijsko strukturo (npr. manj ravni organiziranosti, manj managerjev, večja samostojnost zaposlenih ipd.) - vse to pa zmanjša stroške v organizaciji in poveča njeno učinkovitost. Po drugi strani pa lahko močna organizacijska kultura povzroči, da managerji ne zaznavajo pomen sprememb v gospodarskem in družbenem okolju, ker so preveč zaverovani v splošno usvojena prepričanja v organizaciji, to pa ovira spremembe v organizaciji. Organizacijska kultura v učeči se organizaciji naj bi bila prilagodljiva, spodbujajoča odprtost, enakost, sodelovanje in izmenjavo znanja ter izkušenj, izboljšave in spremembe ter na ta način prispevala k uspešnosti učeče se organizacije.

\section{Literatura}

Bleicher, K. 1994. Normatives Management. Frankfurt - New York: Campus.Brown.

Brown, A. D. 1998. Organizational Culture. Harlow: Financial Times Management, Prentice Hall.

Deal, T. E., in A. A. Kennedy. 1999. The New Corporate Cultures: Revitalizing the Workplace After Downsizing, Mergers, and Reengineering. London: Orion Business Books.

Denison, D. R. 1990. Corporate Culture and Organizational Effectiveness. New York: John Wiley \& Sons, Inc.

De Waal, A. A. 2008. »The Secret of High Performance Organizations.« Management Online Review. http://www.andredewaal.eu/pdf2008/ MORE2008.pdf.

Dimovski, V., in S. Penger. 2008. Temelji managementa. Harlow (Essex): Pearson Education Inc.

Gordon, G. G., in N. DiTomaso. 1992. »Predicting Corporate Performance from Organizational Culture.« Journal of Management Studies 29 (6): $783-98$.

Griffin, R. W. in G. Moorhead. 2014. Organizational Behavior: Managing People and Organizations. New York: McGraw-Hill.

Kavčič, B. 2005. Organizacijska kultura. Celje: Visoka komercialna šola.

Kolenc, I., M. Markič in M. Miklavčič Šumanski. 2007. »Organizacijska kultura kot učinkovito orodje za obvladovanje varnosti in zdravja pri delu.« Delo in varnost 52 (4): 25-30. 
Kotter, J. P., in J. L. Heskett. 1992. Corporate Culture and Performance. New York: Free Press.

Markič, M. 2004. Inoviranje procesov: pogoj za odličnost poslovanja. Koper: Univerza na Primorskem, Fakulteta za management.

O'Reilly, C. A., in J. A. Chatman. 1996. »Culture as Social Control: Corporations, Culture and Commitment.«Research in Organizational Behavior I8 (18): 157-200.

Schermerhorn, J. R., J. G. Hunt in R. N. Osborn. I991. Managing Organizational Behavior. 4. izdaja. Chichester: John Willey.

Sørensen, J. B. 200I. »the Strength of Corporate Culture and the Reliability of Firm Performance. Https://web.stanford.edu/ sorensen/culture\%20 \&\%2oreliability\%2oprovacc (12.3.2017).

Tavčar, M. I. 2006. Management in organizacija: Sinteza konceptov organizacije kot instrumenta in kot skupnost interesov. Koper: Univerza na Primorskem, Fakulteta za management.

Venkatraman, N. in V. Ramanujam. 1986. Measurement of Business Performance in Strategy Research: A Comparison of Approaches. The Academy of Management Review I I (4): 80I-8I 4. 


\title{
${ }^{4}$ \\ Organizacijska klima: zgodovina, pojem in dimenzije
}

\author{
Melita Moretti
}

\section{Zgodovina raziskovanja organizacijske klime}

Obdobje od leta 1939 do sredine 1960 opredeljujemo kot obdobje začetka raziskovanja in razumevanja organizacijske klime kot celote in organizacijski klimi podobnih konstruktov. Za opis organizacijske klime so raziskovalci uporabili izraze kot npr. atmosfera $\mathrm{v}$ organizaciji, osebnost organizacije in znak organizacije ipd. Pojem »klima « so v jedro raziskav s področja socialne psihologije leta 1939 uvedli Lewin, Lippit in White (raziskovali so družbeno klimo, razlike v družbeni klimi pa pripisali voditeljem - družbena klima je bila po njihovem mnenju neposredno nemerljiva in razvidena kot pogajalski mehanizem) (Lewin, Lippit in White 1939), njihov vpliv pa je bil razviden tudi v delih in raziskavah Argyrisa (1958), McGregorja (1960) in Likerta (196I), ki so postavili temelje za vzpon organizacijske psihologije in s tem temelje za vzpon raziskav na področju organizacijske klime.

Obdobje poznih 6o-ih let do zaključka desetletja opredeljujemo kot obdobje ekspanzije raziskav o organizacijski klimi. Raziskave na področju organizacijske klime so bile še razpršene, saj so v tem obdobju raziskovalci temeljne ideje pridobili iz raziskav $\mathrm{z}$ začetka raziskovanja organizacijske klime. $\mathrm{Z}$ raziskavami niso neposredno merili/ocenjevali organizacijske klime, ampak so merili npr. vodenje, socialne oziroma medosebne odnose, sistem nagrajevanja $\mathrm{v}$ organizaciji in na osnovi teh ocen sklepali, kakšna organizacijska klima prevladuje (Ehrhart, Schneider in Macey 2014). So pa raziskovalci v tem obdobju prišli do nekaterih spoznanj o organizacijski klimi - ugotovili so, da obstaja več vrst slednje (Forehand in Gilmer, 1964), da je v daljšem časovnem obdobju relativ- 
no stabilna (Litwin in Stringer 1968; Pritchard in Karasick 1973; Tagiuri 1968a) ter da na organizacijsko klimo vpliva vedenje zaposlenih (Forehand in Gilmer 1964; Litwin in Stringer 1968; Pritchard in Karasick 1973; Tagiuri I968a). Istočasno so se v tem obdobju začele pojavljati kritike nekaterih raziskovalcev npr. Guiona (1973), Johannessona (1973) in Jamesa in Jonesa (1974). Za večino del tega obdobja so bili glavni zadržki v opredelitvi, kaj organizacijska klima je in ali raziskovanje organizacijske klime v teorijo, raziskovanje in poslovno okolje prinaša dodano vrednost. Guion (1973, I 2 I) je menil, da je »organizacijska klima eden najbolj nejasnih pojmov zadnjega časa«. Johannesson (1973) in James in Jones (1974) so izpostavljali podobne pomisleke, vendar pa sta se James in Jones (1974, I107) kljub temu strinjala, da sta zadovoljstvo pri delu in organizacijska klima povezana na dinamičen način. Če se ozremo nazaj, so bile prav te kritike oziroma odzivi na raziskave bistvenega pomena za prihodnji razvoj raziskav na tem področju, saj so bili raziskovalci prisiljeni konceptualizirati organizacijsko klimo. Pomembne raziskave v obdobju poznih 60-tih let do zaključka desetletja 1970 so izpeljali še Schneider in Bartlett (1968), Payne in Pheysey (1971), Frederiksen, Jensen in Beaton (1972), House in Rizzo (1972), Schneider (1972), Schneider in Hall (1972), Hand, Richards in Slocum (1973), Payne in Mansfield (1973), Pritchard in Karasick (1973), Dieterly in Schneider (1974), Lawler, Hall in Oldham (1974), Schneider (1975) Downey, Hellriegel in Slocum (1975), Sims in LaFollette (1975), Muchinsky (1976), Howe (1977), Muchinsky (1977) in drugi.

$S$ kakovostnimi raziskavami organizacijske klime v obliki, kakršno poznamo še danes, so okoli leta 1979-1980 prispevali raziskovalci Jones in James (1979), Schneider, Parkinson in Buxton (1980) ter Zohar (1980). Jones in James (1979) sta poskusila ustvariti merski inštrument, s katerim bi v delovnem okolju zajeli situacijske vidike, ki so neposrednega pomena za posameznikovo doživljanje organizacijskega okolja - t. i. psihološko klimo. Raziskava Schneiderja, Parkinsona in V. M. Buxton (1980) pa je bila prva raziskava, $v$ kateri so se raziskovalci neposredno ukvarjali s preučevanjem storitvene klime z vidika zaposlenih. Za začetnika raziskav o varnostni klimi velja Zohar, ki je leta ı980 objavil študijo o pomembnosti programov za usposabljanje o varnosti. $\mathrm{V}$ raziskavi je razvil merski inštrument, ki je zajemal osem dimenzij varnostnih praks, in sicer: pomembnost programov za usposabljanje o varnosti, odnosi managerjev do varnosti, vpliv varnega ravnanja na napredovanje na delovnem mestu, stopnja nevarnosti na delovnem mestu, vpliv zahtevane delovne hitrosti na varnost, status strokovnjaka za varnost, vpliv varnega ravnanja na 
družbeni status in status odbora za varnost. Zohar je na podlagi neodvisnih ocen varnostnega ravnanja s strani varnostnih inšpektorjev na vzorcu dvajsetih tovarn iz različnih dejavnosti ugotovil, da je varnostna klima statistično značilno povezana s splošno ravnjo varnosti (Zohar 1980).

Do današnjega obdobja je bilo po svetu izvedenih veliko raziskav $s$ področja organizacijske klime, zato je vse nemogoče omeniti. Poleg varnostne (npr. raziskovalci Brown in Holmes 1986; Dedobbeleer in Béland 1991; Hofmann in Stetzer 1998; Probst, Brubaker in Barsotti 2008; Zohar in Tenne-Gazit 2008; Barling, Loughlin in Kelloway 2002; Zohar in Luria 2005; Wallace, Popp in Mondore 2006; Hofmann in Mark 2006; Zohar in Hofmann 2012 in drugi) in storitvene (npr. raziskovalci Schneider, Parkinson in Buxton 1980; Schneider in Bowen 1985; Cooil idr. 2009; Dean 2004; Yagil 2008; Way, Sturman in Raab 2010; Liao in Chuang 2004; Liao in Chuang 2007; Walumbwa idr. 2010; Salanova, Agut in Peiró 2005; Chuang in Liao 2010 in drugi) organizacijske klime, kot tipa organizacijske klime, je moč zaslediti tudi raziskave s področja inovacijske klime (raziskovalci Abbey in Dickson 1983; Anderson in West 1998; King idr. 2007), pravične klime (raziskovalci Mossholder, Bennett in Martin 1998; Colquitt, Noe in Jackson 2002; Ehrhart 2004; Naumann in Bennett 2000), etične klime (raziskovalci Mayer, Kuenzi in Greenbaum 2009; Victor in Cullen 1987; 1988), raznolike klime (raziskovalci Herdman in McMilan-Capehart 2010; McKay, Avery in Morris 2008; Mor Barak, Cherin in Berkman 1998), iniciativne klime (raziskovalci Baer in Frese 2003; Michaelis, Stegmaier in Sonntag 2010), klime enakih možnosti (raziskovaci Walsh idr. 2010), klime za prenos usposabljanja (raziskovalci Rouiller in Goldstein 1993; Tracey, Tannenbaum in Kavanaugh 1995), vodstvene klime (raziskovalci Chen in Bliese 2002; Schyns in Van Veldhoven 2010) in tehničnoposodobljene klime (raziskovalca Kozlowski in Hults 1987) ipd.

V Sloveniji je organizacijsko klimo prvi raziskoval Konrad, in sicer leta $1987 . \mathrm{Z}$ njenim raziskovanjem so se kasneje ukvarjali Možina, Lipičnik, Zupan in drugi. V letu 200 r je skupina svetovalnih podjetij pod okriljem Gospodarske zbornice Slovenije pripravila projekt raziskovanja in spremljanja organizacijske klime $\mathrm{v}$ slovenskih organizacijah, poimenovan $\mathrm{SiOK}$ (slovenska organizacijska klima), ki se izvaja še danes.

\section{Pojem organizacijske klime in njene dimenzije}

Organizacijska klima je večdimenzionalen pojem, ki ga je težko definirati in kaže moč prevladujočih vrednot, norm in vedenj večine zaposlenih $\mathrm{v}$ organizaciji (Ehrhart, Schneider in Macey 2014; Bahrami idr. 2016; Kang 
idr. 2016). Organizacijska klima je skozi daljše časovno obdobje relativno stabilna, po njej se organizacije ločijo med seboj (Chaudhary, Rangnekar in Barua 2014; West in Lyubovnikova 2015).

V nadaljevanju povzemamo posamezne definicije različnih avtorjev, ki po našem mnenju pojem organizacijske klime najjasneje opredeljujejo. Tagiuri in Litwin (1968) organizacijsko klimo opredeljujeta kot kakovost notranjega okolja organizacije, ki vpliva na vedenje zaposlenih in jo opredelimo kot vrednost posameznega sklopa značilnosti (ali lastnosti) organizacije. Pojavlja se v številnih »mehanizmih« organizacije, vključno z managementom, komunikacijo, izobraževanjem ipd. (Ehrhart, Schneider in Macey 2014). Litwin (1968) organizacijsko klimo opredeljuje kot skupni vzorec vrednot, ki obstajajo v nekem okolju. Organizacijska klima nastaja na različne načine, vključno z vodenjem, komunikacijo, izobraževanjem ipd. (Frederiksen, Jensen in Beaton 1972). L. J. Mullins (2007) je mnenja, da temelji na percepciji članov v odnosu do organizacije in jo je mogoče razumeti kot stanje medsebojnega zaupanja in razumevanja med njenimi udeleženci. Pritchard in Karasick (1973) organizacijsko klimo opredelita kot psihološko vzdušje v organizaciji. Robbins in Judge (20I4) menita, da organizacijska klima ni lastnost posameznikov, temveč lastnost organizacij in njihovih organizacijskih enot. Griffin in Moorhead (2014) sta organizacijsko klimo opredelila kot zaznavo članov organizacije glede na trenutne razmere $\mathrm{v}$ organizaciji ter na povezave med zaposlenimi, delovnimi skupinami in delovno uspešnostjo.

Če povzamemo različne opredelitve, je organizacijska klima psihološki proces in skupek lastnosti prevladujočega trenutnega delovnega okolja, ki jih zaposleni posredno ali neposredno zaznavajo $\mathrm{v}$ organizaciji, in je $\gg$ glavna sila «, ki vpliva na vedenje in obnašanje zaposlenih - vsebuje t. i. mehke dimenzije »osebnosti « organizacije in posameznikov v organizaciji. Lahko rečemo tudi, da je organizacijska klima trenutna zaznava politike, prakse, dogodkov in posameznih postopkov večine zaposlenih $\mathrm{v}$ organizaciji, nekaj, kar zaposleni občutijo, se s tem poistovetijo in to pričakujejo.

V posamezni raziskavi organizacijske klime so avtorji poudarjali neposredne učinke ravni razvitosti organizacijske klime na rezultate organizacije. Npr., iz povprečne ravni storitvene klime je mogoče predvidevati izkušnjo strank (Schneider in White 2004); iz povprečne ravni varnostne klime je mogoče predvidevati stopnjo poškodb (Zohar 2000) in nesreč (Zohar in Luria 2005) ipd. Iz raziskav je prav tako mogoče razbrati, da se višja raven raznolikosti enot $\mathrm{v}$ organizaciji (Colquitt, Noe in Jackson 2002) in višja raven socialne interakcije med zaposlenimi in managerji 
(González-Roma idr. 2002) odražata v višji ravni organizacijske klime. Od začetka raziskav organizacijske klime (npr. Fleishman 1953; Lewin idr. 1939; McGregor 1960) je razvidno, da imajo managerji odločilno vlogo pri ustvarjanju organizacijske klime in da organizacijska klima deluje kot mehanizem, preko katerega imajo managerji vpliv na ostale zaposlene sodelavce v organizaciji. Številni kadrovski in drugi podporni procesi v organizaciji služijo kot podlaga za organizacijsko klimo v podjetju ali drugi ustanovi (npr. Salanova, Agut in Peiró 2005; Schneider, White in Paul 1998; Wallace, Popp in Mondore 2006), ko pa se s temi procesi osredinjajo na izbrani rezultat organizacije, bo njihov odnos z organizacijsko klimo še močnejši (Hong idr. 2013).

$\gg Z$ drava« organizacijska klima ima po L. J. Mullins (2007) naslednje značilnosti:

- integrira organizacijske in osebne smotre ter cilje,

- uveljavlja najprimernejšo organizacijsko strukturo, ki temelji na zahtevah družbenega sistema,

- omogoča demokratičnost delovanja, vključno z vsemi možnostmi za sodelovanje,

- spodbuja medsebojno zaupanje, pozornost in podporo med različnimi ravnmi zaposlenih $\mathrm{v}$ organizaciji,

- omogoča odprto komunikacijo med zaposlenimi,

- spodbuja primerno vedenje managerjev in stile vodenja zaposlenih,

- omogoča pravičen sistem nagrajevanja, ki temelji na pozitivnem ravnanju,

- omogoča priložnost za osebni razvoj in napredovanje,

- spodbuja skrb za kakovost delovnega okolja in delovnega mesta,

- spodbuja pripadnosti zaposlenih organizaciji - slednji so zaposleni zvesti in imajo občutek, da so njen pomemben člen.

V primeru, da je potrebno oranizacijsko klimo izboljšati (jo spremeniti), naj bi se pozornost namenila poprej navedenim značilnostim. Poudariti pa velja, da $\mathrm{z} \gg \mathrm{zdravo}$ « organizacijsko klimo sami po sebi še ne zagotavljamo večje učinkovitosti organizacije, vendar pa naj bi verjetneje dosegala optimalno zmogljivost (Mullins 2007). Spreminjanje organizacijske klime je zapleten proces, narekuje ga družbeno okolje, v katerem organizacija deluje ali pa je pogojeno z življenjskim ciklom organizacije (npr. ko se v organizaciji soočajo $s$ težavami, je sprememba organizacijske klime nujna, prav tako je sprememba organizacijske klime potrebna z rastjo organizacije) - tej novi organizacijski klimi naj bi se zaposleni 
prilagodili in jo dojeli (Ehrhart, Schneider in Macey 2014). Organizacijska klima se zaradi družbenega okolja, v katerem organizacija deluje, najpogosteje spreminja nenadzorovano in sama po sebi, kar ima za posledico slabo delovanje organizacije (taka organizacijska klima ni skladna s prizadevanji managerjev). Nadzorovano spreminjanje organizacijske klime poteka na osnovi navodil, ukrepov in predpisov s strani managerjev, $s$ katerimi poskušajo slednji uravnavati vedenje in obnašanje posameznega zaposlenega. Naj poudarimo, da večine dejavnikov organizacijske klime ni mogoče spreminjati na podlagi navodil, ukrepov in predpisov (npr. medsebojnih odnosov v organizaciji), ampak naj bi zaposleni sodelavci verjeli in zaupali managerjem, ki predlagajo te ukrepe (Ashkanasy, Wilderom in Peterson 201 I).

Organizacijsko klimo je mogoče raziskovati na mikro ravni (fokus raziskovanja je izbrana dimenzija organizacijske klime ali izbrano mikro okolje neke organizacije) ali makro ravni (cilj raziskovanja je ugotoviti, kako zaposleni razumejo in dojemajo organizacijsko klimo v izbranem makro okolju neke organizacije) (Schneider idr. 20I I). Kot so različne definicije organizacijske klime, se razlikujejo tudi opredelitve njenih dimenzij- raziskovalci organizacijsko klimo analizirajo v različnih okoljih, dejavnostih in oblikah organiziranosti. $\mathrm{V}$ nadaljevanju navajamo nekatere dimenzije organizacijske klime, kot so jih oblikovali in poimenovali nekateri raziskovalci:

- Litwin in Stringer (1968): 1) organizacijska struktura, 2) odgovornost, 3) nagrajevanje, 4) tveganje, 5) toplina, 6) podpora, 7) standardi, 8) konflikti in 9) identiteta;

- Campbell idr. (1970): I) osebna avtonomija, 2) stopnja strukture, temelječe na položaju, 3) usmerjenost k nagrajevanju ter 4) upoštevanje drugih, toplina in podpora;

- Steers (1977): I) struktura nalog, 2) odnos med nagradami in kaznimi, 3) centralizacija sprejemanja odločitev, 4) poudarjanje dosežkov, 5) poudarjanje izobraževanja in razvoja, 6) varnost proti tveganju, 7) odprtost proti branjenju, 8) status in morala, 9) priznanja in povratna informacija, Io) splošna organizacijska kompetentnost in fleksibilnost;

- Jones in James (1979): I) konflikt in dvoumnost, 2) izziv na delovnem mestu, pomen in raznolikost, 3) podpora in spodbujanje vodje, 4) sodelovanje skupine, prijateljstvo in toplina, 5) poslovni in organizacijski duh, 6) delovni standardi;

- Tang in Chen (200I): I) ekologija (materialni viri organizacije: oprema, materiali, inštrumenti, zgradbe in finance); 2) ozad- 
je (značilnosti članov organizacije: družbeno-ekonomski status, stopnja izobrazbe, samozavedanje), 3) družbeni sistem (interakcija med formalnimi in neformalnimi vlogami v organizaciji), 4) organizacijska kultura (obstoječe norme, vrednostni sistemi, prepričanja, kognitivne strukture);

- Robbins (200I): I) inovacije in prevzem tveganj, 2) pozornost na podrobnosti, 3) usmerjenost $\mathrm{k}$ izidom, 4) usmerjenost $\mathrm{k}$ ljudem, 5) usmerjenost $\mathrm{k}$ timom, 6) stabilnost in 7) napadalnost;

- Zhang in Liu (2010): I) ekologija, 2) ozadje, 3) družbeni sistem in 4) kultura;

- Castro in Martins (2010): I) vodenje neposredno nadrejenih, 2) preoblikovanje in raznolikost, 3) osebna rast in razvoj, 4) medosebna pripadnost in ustreznost, 5) splošno občutenje zadovoljstva z delom, 6) dobro počutje zaposlenih, 7) ugled, 8) plača, 9) zanimivo in izzivov polno delo, Io) fizično delovno okolje, I I) priznanja in prepoznavnost;

- Eustace in Martins (20I4): I) management učinkovitosti, 2) prakse samovodenja, 3) inovacije in opolnomočenje, 4) odnos z zaposlenimi, 5) vedenje vršnih managerjev, 6) raznolikost, 7) ekonomsko opolnomočenje, 8) korporativni ugled in upravljanje, 9) organizacijska podpora;

- SiOK - Slovenska organizacijska klima (Biro Praxis 2016): I) odnos do kakovosti, 2) zadovoljstvo z delovnim okoljem, 3) motivacija in zavzetost, 4) inovativnost in iniciativnost, 5) vodenje, 6) pripadnost organizaciji, 7) organiziranost, 8) strokovna usposobljenost in učenje, 9) poznavanje poslanstva in vizije ter ciljev, Iо) nagrajevanje, I I) notranji odnosi, I2) notranje komuniciranje in informiranje ter 13) razvoj kariere.

\section{Povzetek poglavja}

V tem poglavju smo predstavili zgodoviski pregled raziskovanja organizacijske klime. Obdobje od leta 1939 do sredine 1960 smo opredelili kot obdobje začetka raziskovanja in razumevanja klime kot celote in klimi podobnih konstruktov. Obdobje poznih 6o-ih let do zaključka desetletja smo opredelili kot obdobje ekspanzije raziskav o organizacijski klimi. V tem obdobju organizacijska klima ni bila »neposredno « merljiva, ampak so jo avtorji opredelili npr. posredno preko vodenja, socialnih oziroma medosebnih odnosov, sistema nagrajevanja v organizaciji ipd. Kvantitativne raziskave organizacijske klime, kakršne poznamo še danes, pa so 
raziskovalci začeli izvajati leta I979-ı980. V nadaljevanju smo oblikovali naslednjo definicijo organizacijske klime:

Organizacijska klima je psihološki proces, je skupek lastnosti prevladujočega sedanjega delovnega okolja, ki jih zaposleni posredno ali neposredno zaznavajo v organizaciji, in je, glavna sila, ki vpliva na vedenje zaposlenih - je trenutna zaznava politike, prakse, dogodkov in posameznih postopkov večine zaposlenih v organizaciji, nekaj, kar zaposleni občutijo, se s tem poistovetijo in to pričakujejo.

V primeru, da je treba organizacijsko klimo izboljšati, jo je mogoče spremeniti (vendar ne lahko) nadzorovano, na osnovi navodil, ukrepov in predpisov, s katerimi poskušajo managerji uravnavati vedenje in obnašanje posameznega zaposlenega sodelavca. Organizacijska klima se spremi-

nja tudi nenadzorovano, zaradi vplivov iz družbenega in naravnega okolja, v katerem organizacije delujejo in naj bi vplivlo na slabšanje njihovega delovanja.

\section{Literatura}

Abbey, A., in J. W. Dickson 1983. »R \& D Work Climate and Innovation in Semiconductors.« Academy of Management Journal 26 (2): 362-68.

Anderson, N. R., in M. A. West. I998. »Measuring Climate for Work Group Innovation: Development and Validation of the Team Climate Inventory.« Journal of Organizational Behavior 19 (3): 235-58.

Argyris, C. 1958. »Some Problems in Conceptualizing Organizational Climate: A Case Study of a Bank.«Administrative Science Quarterly 2 (4): $50 \mathrm{I}-20$.

Ashkanasy, N. M., C. P. M. Wilderom in M. F. Peterson. 20 I I. Organizational Culture and Climate. Thousand Oaks: Sage Publications.

Baer, M., in M. Frese. 2003. »Innovation Is Not Enough: Climates for Initiative and Psychological Safety, Process Innovations, and Firm Performance.« Journal of Organizational Behavior 24 (I): 45-68

Bahrami, M. A., O. Barati, M. Ghoroghchian, R. Montazer-alfaraj, M. R. Ezzatabadi. 2016. »Role of Organizational Climate in Organizational Commitment: The Case of Teaching Hospitals.« Osong Public Health Research Perspectives 7 (2): 96-100.

Barling, J., C. Loughlin in E. K. Kelloway. 2002. »Development and Test of a Model Linking Safety-Specific Transformational Leadership and Occupational Safety.« Journal of Applied Psychology 87 (I): 488-96. 
Biro Praxis. 2016. »Kako merimo organizacijsko klimo in zadovoljstvo zaposlenih. «http://www.biro-praxis.si/?viewPage $=36$.

Brown, R. L., in H. Holmes. 1986. »The Use of a Factor-Analytic Procedure for Assessing the Validity of an Employee Safety Climate Model.« Accident Analysis \& Prevention I 8 (6): 455-70.

Campbell, J. P., M. D. Dunnette, E. E. Lawler III in K. E. Weick. 1970. Managerial Behavior, Performance and Effectiveness. New York: McGrawHill.

Castro, M. L., in N. Martins. 2010. »The Relationship between Organisational Climate and Employee Satisfaction in a South African Information and Technology Organisation. « SA Journal of Industrial Psychology/SA Tydskrifvir Bedryfsielkunde 36 (I): 2-9.

Chaudhary, R., S. Rangnekar in M. K. Barua. 2014. »Organizational Climate, Climate Strength and Work Engagement.« Procedia - Social and Behavioral Sciences I33 (I): 291-303.

Chen, G., in P. D. Bliese. 2002. »The Role of Different Levels of Leadership in Predicting Self- And Collective Efficacy: Evidence for Discontinuity.« Journal of Applied Psychology 87 (3): 549-56.

Chuang, C-H., in H. Liao. 20ro. »Strategic Human Resource Management in Service Context: Taking Care of Business by Taking Care of Employees and Customers.« Personnel Psychology 63 (I): 153-96.

Colquitt, J. A., R. A. Noe in C. L. Jackson. 2002. »Justice in Teams: Antecedents and Consequences of Procedural Justice Climate.« Personnel Psychology 58 (I): 83-109.

Cooil, B., L. Aksoy, T. L. Keiningham in K. M. Marytott. 2009. »The Relationship of Employee Perceptions of Organizational Climate to Business-Unit Outcomes: An MLPS Approach.« Journal of Service Research II (3): 277-94.

Dean, A. 2004. »Links between Organizational and Customer Variables in Service Delivery: Evidence, Contradictions, and Challenges.« International Journal of Service Industry Management I5 (4): 332-50.

Dedobbeleer, N., in F. Béland. I991. »A Safety Climate Measure for Construction Sites.«Journal of Safety Research 22 (2): 97-103.

Dieterly, D., in B. Schneider. 1974. »The Effect of Organizational Environment on Perceived Power and Climate: A Laboratory Study.« Organizational Behavior and Human Performance II (I): 316-37.

Downey, H. K., D. Hellriegel in J. W. Slocum. 1975. »Congruence between Individual Needs, Organizational Climate, Job Satisfaction and Performance.« Academy of Management Journal I 8 (I): I 49-55. 
Ehrhart, M. G. 2004. »Leadership and Procedural Justice Climate as Antecedents of Unit-Level Organizational Citizenship Behavior.« Personnel Psychology 57 (I): 6I-94.

Ehrhart, M. G., B. Schneider in W. H. Macey. 2014. Organizational Climate and Culture: An Introduction to Theory, Research and Practice. New York: Routledge.

Eustace, A., in N. Martins. 201 4. »The Role of Leadership in Shaping Organisational Climate: An Example from the FMCG Industry.« $S A$ Journal of Industrial Psychology/SA Tydskrif vir Bedryfsielkunde 40 (I): 4.

Fleishman, E. A. 1953. \Leadership Climate, Human Relations Training and Supervisory Behavior.« Personnel Psychology 6 (I): 205-22.

Forehand, G. A., in G. H. Gilmer. 1964. »Environmental Variation in Studies of Organizational Behavior.« Psychological Bulletin 62 (6): 361-382.

Frederiksen, N. O. (1966). »Some Effects of Organizational Climates.« Raiskovalni memorandum RM-66-2I. Washington: Educational Testing Services.

Frederiksen, N., O. Jensen in A. E. Beaton. 1972. Prediction of Organizational Behavior. New York: Pergamon.

González-Romá, V., J. M. Peiró in N. Tordera. 2002. »An Eexamination of the Antecedents and Moderator Influences of Climate Strength.«Journal of Applied Psychology 87 (I): 465-73.

Griffin, R. W., in G. Moorhead. 2014. Organizational Behavior: Managing People and Organizations. New York: McGraw-Hill.

Guion, R. M. 1973. »A Note on Organizational Climate.« Organizational Behavior and Human Performance 9 (I): 120-25.

Hand, H., M. Richards in J. Slocum. 1973. »Organizational Climate and the Effectiveness of a Human Relations Training Program.« Academy of Management Journal I6 (2): I85-95.

Herdman, A. O., in A. McMilan-Capehart. 20ı o. »Establishing a Diversity Program Is Not Enough: Exploring the Determinants of Diversity Climate.« Journal of Business and Psychology 25 (I): 39-53.

Hofmann, D. A., in B. Mark. 2006. »An Investigation of the Relationship between Safety Climate and Medication Errors as Well as Other Nurse and Patient Outcomes.« Personnel Psychology 59 (4): 847-69.

Hofmann, D. A., in A. Stetzer. 1998. »The Role of Safety Climate and Communication in Accident Interpretation: Implications for Learning from Negative Events.« Academy of Management Journal 4I (I): 644-58. 
Hong, Y., H. Liao, J. Hu in K. Jiang. 2013. »Missing Link in the Service Profit Chain: A Meta-Analytic Review of the Antecedents, Consequences, and Moderators of Service Climate.« Journal of Applied Psychology 98 (2): $237-67$.

House, R. J., in J. R. Rizzo. 1972. »Toward the Measurement of Organizational Practices: Scale Development and Validation.«Journal of Applied Psychology 56 (I): 388-96.

Howe, J. G. 1977. »Group climate: An Exploratory Analysis of Construct Validity.« Organizational Behavior \& Human Performance I9 (I): Io625.

James, L. R., in A. P. Jones. 1974. »Organizational Climate: A Review o Theory and Research.« Psychological Bulletin 8I (I2): 1096-I I 2.

Johannesson, R. 1973. »Some Problems in the Measurement of Organizational Climate.«Organizational Behavior and Human Performance Io (I): I I $8-45$.

Jones, A. P., in L. R. James. 1979. »Psychological Cclimate: Dimensions and Relationships of Individual and Aggregated Work Environment Perceptions.« Organizational Behavior and Human Performance 23 (I): $20 \mathrm{I}-$ 50.

Kang, J. H., J. G. Matusik, T. Y. Kim in J. M. Phillips. 2016. »Interactive Effects of Multiple Organizational Climates on Employee Innovative Behavior in Entrepreneurial Firms: A Crosslevel Investigation.« Journal of Business Venturing 3 I (6): 628-42.

King, E B., K. de Chermont, M. West, J. F. Dawson in M. R. Hebl. 2007. »How Innovation Can Alleviate Negative Consequences of Demanding Work Contexts: The Influence of Climate for Innovation on Organizational Outcomes.«Journal of Occupational and Organizational Psychology $80(4): 63 \mathrm{I}-45$.

Konrad, E. 1987. »Vodenje in motivacija za delo: pomen organizacijske kulture in organizacijske klime.« $\mathrm{V} X V$. posvetovanje psihologov Slovenije, 99-ıoo. Ljubljana: Društvo psihologov SR Slovenije.

Kozlowski, S. W. J., in B. M. Hults. 1987. »An Exploration of Climates for Technical Updating and Performance.« Personnel Psychology 40 (I): $539-63$.

Lawler, E. E., D. T. Hall in G. R. Oldham. 1974. »Organizational Climate: Relationship to Organizational Structure, Process and Performance.« Organizational Behavior and Human Performance II (I): 139-55. 
Lewin, K., R. Lippitt in R. K. White. 1939. »Patterns of Aggressive Behavior in Experimentally Created,Social Climates'.«Journal of Social Psychology Iо (I): 27I-99.

Liao, H. in A. Chuang. 2004. »A Multilevel Investigation of Factors Influencing Employee Service Performance and Customer Outcomes.« Academy of Management Journal 47 (I): 4I-58.

Liao, H., in A. Chuang. 2007. »Transforming Service Employees and Climate: A multilevel Multi-Source Examination of Transformational Leadership in Building Long-Term Service Relationships.« Journal of Applied Psychology 92 (4): 1006-19.

Likert, R. 1961. New Patterns of Management. New York: McGraw-Hill.

Litwin, G. H. 1968. »Climate and Behavior Theory: An Environmental Perspective on Theories of Individual and Organizational Behavior.« V Organizational climate: Explorations of a concept, ur. R. Tagiuri in G. H. Litwin, 35-6r. Boston: Harvard University.

Litwin, G. H., in R. A. Stringer. 1968. Motivation and Organizational Climate. Cambridge: Harvard Business School, Division of Research.

Mayer, D. M., M. Kuenzi in R. L. Greenbaum. 2009. »Making Ethical Climate a Mainstream Management Topic: A Review, Critique, and Prescription for the Empirical Research on Ethical Climate.«V Psychological Perspectives on Ethical Behavior and Decision Making, ur. D. De Cremer, I8I-213. Greenwich, CT: Information Age Publishing.

McGregor, D. M. 1960. The Human Side of Enterprise. New York: McGrawHill.

McKay, P. F., D. R. Avery in M. A. Morris. 2008. »Mean Racial-Ethnic Differences in Employee Sales Performance: The Moderating Role of Diversity Climate.«Personnel Psychology 6I (I): 349-74.

Michaelis, B., R. Stegmaier in K. Sonntag. 2010. »Shedding Light on Followers' Innovation Implementation Behavior: The Role of Transformational Leadership, Commitment to Change, and Climate for Initiative.«Journal of Managerial Psychology 25 (4): 408-29.

Mor Barak, M. E., D. A. Cherin in S. Berkman. 1998. »Organizational and Personal Dimensions of Diversity Climate: Ethnic and Gender Differences in Employee Perceptions.« Journal of Applied Behavioral Science 34 (I): 82-104.

Mossholder, K. W., N. Bennett in C. L. Martin. 1998. »A Multilevel Analysis of Procedural Justice Context.« Journal of Organizational Behavior I9 (I): $13 \mathrm{I}-4 \mathrm{I}$. 
Muchinsky, P. M. 1976. »An Assessment of the Litwin and Stringer Organization Climate Questionnaire: An Empirical and Theoretical Extension of the Sims and LaFollette Study.« Personnel Psychology 29 (I): $371-92$.

Muchinsky, P. M. 1977. »Organizational Communication: Relationships to Organizational Climate and Job Satisfaction.« Academy of Management Journal 20 (4): 592-607.

Mullins, L. J. 2007. Management and Organizational Behaviour. Harlow: Pearson Education; London: FT Financial Times; New York: Prentice Hall.

Naumann, S. E., in N. Bennett. 2000. »A Case for Procedural Justice Climate: Development and Test of a Multilevel Model.« Academy of Management Journal 43 (I): 88I-89.

Payne, R. L., in R. Mansfield. I973. »Relationships of Perceptions of Organizational Climate to Organizational Structure, Context, and Hierarchical Position.«Administrative Science Quarterly I 8 (4): 515-26.

Payne, R. L., in D. C. Pheysey. I97ı. »G. G. Stern's Organizational Climate Index: A Reconceptualization and Application to Business Organizations.« Organizational Behavior and Human Performance 6 (I): 77-98.

Pritchard, R. D., in B. Karasick. 1973. »The Effects of Organizational Climate on Managerial Job Performance and Job Satisfaction.« Organizational Behavior and Human Performance 9 (I): 126-46.

Probst, T., T. Brubaker in A. Barsotti. 2008. »Organizational Under-Reporting of Injury Rates: An Examination of the Moderating Effect of Organizational Safety Climate.« Journal of Applied Psychology 93 (5): I $147-54$.

Robbins, S. P. 2001. Organizational Behavior. New Jersey: PrenticeHall.

Robbins, S. P., in T. A. Judge. 2013. Organizational Behavior. Upper Saddle River: Pearson Prentice Hall.

Rouiller, J. Z., in I. L. Goldstein. 1993. »The Relationship between Organizational Transfer Climate and Positive Transfer of Ttraining. $\ll \mathrm{Hu}$ man Resource Development Quarterly 4 (4): 377-90.

Salanova, M., S. Agut in J. M. Peiró. 2005. >Linking Organizational Resources and Work Engagement to Employee Performance and Customer Loyalty: The Mediation Of Service Climate.« Journal of Applied Psychology 90 (6): 1 217-27.

Schneider, B. 1972. »Organizational Climate: Individual Preferences and Organizational Realities.« Journal of Applied Psychology 56 (3): 2 I I-I 7. 
Schneider, B. 1975. »Organizational Climates: An Essay.« Personnel Psychology 28 (4): 447-79.

Schneider, B., in C. J. Bartlett. 1968. »Individual Differences and Organizational Climate, I: The Research Plan and Questionnaire Development.« Personnel Psychology 2 I (3): 323-33.

Schneider, B., in D. E. Bowen. 1995. Winning the Service Game. Boston: Harvard Business School Press.

Schneider, B., in D. T. Hall. 1972. »Towards Specifying the Concept of Work Climate: A Study of Roman Catholic Diocesan Priests.«Journal of Applied Psychology 56 (I): 447-55.

Schneider, B., in S. S. White. 2004. Service Quality: Research Perspectives. Thousand Oaks: Sage.

Schneider, B., J. J. Parkington in V. M. Buxton. I980. »Employee and Customer Perceptions of Service in Banks.« Administrative Science Quarterly 25 (I): $252-67$.

Schneider, B., S. S. White in M. C. Paul. 1998. »Linking Service Climate and Customer Perceptions of Service Quality: Test of a Causal Model.« Journal of Applied Psychology 83 (2): 150-63.

Schyns, B., in M. Van Veldhoven. 2010. »Group Leadership Climate and Individual Organizational Commitment: A Multilevel Analysis.«Journal of Personnel Psychology 9 (2): 57-68.

Sims, H. P., in W. LaFollette. 1975. »An Assessment of the Litwin and Stringer Organization Climate Questionnaire.« Personnel Psychology 28 (I): $19-38$.

Steers, R. M. 1977. Organizational Effectiveness: A Behavioral View. Santa Monica: Goodyear.

Tagiuri, R. 1968. »The Concept of Organizational Climate.«V Organizational Climate: Explorations of a Concept, ur. R. Tagiuri in G. H. Litwin, I I-32. Boston: Harvard University.

Tagiuri, R., in G. H. Litwin. 1968. Organizational Climate: Explorations of a Concept. Boston: Harvard University.

Tang, J., in W. Q. Chen. 200I. >From <Organizational Climate> to ,Organizational Culture - The Logic of Concept Development.« Journal of Development in Psychology 9 (I): 62-65.

Tracey, J. B., S. I. Tannenbaum in M. J. Kavanaugh. 1995. »Applying Trained Skills on the Job: The Importance of the Work Environment.« Journal of Applied Psychology 80 (2): 239-52. 
Victor, B., in J. B. Cullen. 1987. »A Theory and Measure of Ethical Climate in Organizations.« V Research in Corporate Social Performance and Policy, ur. W. C. Frederick, 5 I-7I. Greenwich, CT: JAI Press.

Victor, B., in J. B. Cullen. 1988. »The Organizational Bases of Ethical Work Climates.« Administrative Science Quarterly 33 (I): IOI-25.

Wallace, J. C., E. Popp in S. Mondore. 2006. »Safety Climate as a Mediator between Foundation Climates and Occupational Accidents: A Group-Level Investigation.« Journal of Applied Psychology 91 (3): 68I88.

Walsh, B. M., R. A. Matthews, M. D. Tuller, K. M. Parks in D. P. McDonald. 2010. »A Multilevel Model of the Effects of Equal Opportunity Climate on Job Satisfaction in the Military.« Journal of Occupational Health Psychology is (2): 191-207.

Walumbwa, F. O., S. J. Peterson, B. J. Avolio in C. A. Hartnell. 201 o. »Relationships of Leader and Follower Psychological Capital, Service Climate, and Job Performance.« Personnel Psychology 63 (4): 937-63.

Way, S. A., M. C. Sturman in C. Raab. 2010. »What Matters More? Contrasting the Effects of Job Satisfaction and Service Climate on Hotel Food and Beverage Managers' Job Performance.« Cornell Hotel Quarterly 5 I (3): 379-97.

West, M. A., in J. Lyubovnikova. 2015. »Organizational Climate.« V International Encyclopedia of the Social \& Bahavioral Sciences, ur. James D. Wright, 322-26. Oxford: Elsevier Science \& Technology.

Yagil, D. 2008. The Service Providers. New York: Palgrave Macmillan.

Zhang, J., in Y. Liu. 2010. »Organizational Climate and its Effects on Organizational Variables: An Empirical Study.« International Journal of Psychological Studies 2 (2): I89-201.

Zohar, D. 2000. »A Group Level Model of Safety Climate: Testing the Effect of Group Climate on Microaccidents in Manufacturing Jobs.« Journal of Applied Psychology 85 (I): 587-96.

Zohar, D., in D. A. Hofmann. 2012. »Organizational Culture and Climate.« V The Oxford Handbook of Industrial and Organizational Psychology, ur. S. W. J. Kozlowski, 643-66. Oxford, UK: Oxford University Press.

Zohar, D., in G. Luria. 2005. »A Multi-Level Model of Safety Climate: Cross-Level Relationships between Organization and Group-Level Climates.« Journal of Applied Psychology 90 (4): 616-28. 
Organizacijska kultura in organizacijska klima

Zohar, D., in O. Tenne-Gazit. 2008. »Transformational Leadership and Group Interaction as Climate Antecedents: A Social Network Analysis.«Journal of Applied Psychology, 93 (4): 744-57. 


\title{
Organizacijska klima in poslovanje organizacije
}

\author{
Melita Moretti in Mirko Markič
}

\section{Organizacijska klima in zdravje zaposlenih}

Svetovna zdravstvena organizacija (1948) zdravje opredeljuje kot »stanje popolnega telesnega (fizičnega), duševnega (mentalnega) in socialnega blagostanja/ugodja in ne zgolj stanje odsotnosti bolezni ali betežnosti/ nemoči«. Številne raziskave so pokazale, da je slabo zdravstveno stanje povezano z nižjo kakovostjo življenja, nižjo produktivnostjo, višjo odsotnostjo $z$ delovnega mesta in $s$ stroški zaradi izgube produktivnosti ter izdatki za zdravstveno nego za posameznika, podjetja in druge ustanove ali družbo (Danna in Griffin 1999; Cartwright in Cooper 2013). Prav tako nekateri (Ostroff in Bowen 2000; Connelly idr. 201 I) menijo, da pozitivna organizacijska klima, $s$ katero se spodbuja zdravje zaposlenih, slednjim daje $\gg$ signale $\ll$, da se v organizaciji zdravje ceni. Tudi Tetrick in Peiró (2016) sta mnenja, da so zaposleni bolj zavezani k ohranjanju in izboljševanju svojega zdravja, če imajo občutek, da se njihovo zdravje pozitivno vrednoti.

Organizacijsko klimo, ki spodbuja zdravje zaposlenih, sta Sonnentag in Pundt $(2016,260)$ opredelila kot $\gg$ odnos zaposlenih do organizacijskih prizadevanj za zdravo vedenje zaposlenih «. Schulz, Zacher in Lippke (2017) menijo, da organizacijska klima, s katero spodbujamo zdravje zaposlenih v organizaciji, nastaja skozi proces od spodaj navzgor in tvori skupni konstrukt na ravni celotne organizacije. Ta vpliva na izide, ki so povezani z zdravjem - zaposleni so bolj motivirani, obnašajo se skladno s pričakovanji in splošnimi praksami svojih sodelavcev oziroma tvorijo timsko klimo (Ehrhart in Naumann 2004; Schneider, Ehrhart in Macey 2013). 
$S$ področjem preučevanja odnosov med zaznavanjem in dojemanjem organizacijske klime, ki spodbuja zdravje zaposlenih, ter rezultati na ravni posameznega zaposlenega so se ukvarjali različni avtorji. Iz raziskave Ribisla and Reischla (1993) je razvidno, da je zaznava organizacijske klime, ki spodbuja zdravje zaposlenih, negativno povezana s samooceno simptomov slabega fizičnega stanja posameznika (npr. glavobol, slabši apetit, vrtoglavica ipd.) in pozitivno povezana s samooceno zdravju koristnega obnašanja posameznikov (npr. telesna aktivnost, zdrava prehrana, zmanjševanje kajenja ipd.) ter $\mathrm{z}$ odnosom posameznika do delovnega mesta (npr. zadovoljstvo na delovnem mestu, manjši psihični pritisk ipd.).

Iz raziskave K. Basen-Engquist idr. (1998) je v nasprotju z raziskavo Ribisla and Reischla (1993) razvidno, da organizacijska klima na deloviščih, ki spodbuja zdravje zaposlenih (zdravo prehranjevanje in kajenje), ni povezana $z$ obnašanjem teh posameznikov.

Iz raziskave Schulza, Zacherja in S. Lippke (2017) je razvidno, da je organizacijska klima, $s$ katero $\mathrm{v}$ timih spodbujamo zdravje zaposlenih, pozitivno povezana s subjektivnim mnenjem članov skupine o njihovem splošnem zdravstvenem stanju, npr. z njihovim duševnim zdravjem ter njihovo delovno zmožnostjo, ter negativno povezana s prezentizmom. Iz raziskava je prav tako razvidno, da organizacijska klima, $s$ katero $v$ timih spodbujamo zdravje zaposlenih, blaži negativno povezanost med starostjo zaposlenih in delovno sposobnostjo.

\section{Organizacijska klima in vpetost invalidnih oseb v organizaciji}

Veliko je raziskav, ki so povezane $\mathrm{z}$ invalidnimi osebami na delovnem mestu (napotitvijo delavcev) (npr. Chen in Huang 2007; Hasmin, Ishak in Hilmi 2015). V organizaciji, v kateri zaposlujejo invalidne osebe, se soočajo $s$ številnimi izzivi, predvsem v prvi fazi zaposlitve, in to zaradi procesa ujemanja med delovnimi zahtevami in stopnjo invalidnosti posameznika (Newton, Ormerod in Thomas 2007; Furuoka idr. 2011). Ta in Leng (2013) menita, da kljub težavam, s katerimi se v organizaciji soočajo pri zaposlovanju invalidnih oseb, so slednje lahko zelo predane delu. Po mnenju Pagan-Rodrigueza (2009) so invalidne osebe na delovnem mestu srečnejše kot neinvalidne osebe - predvsem zaradi doseženih pričakovanj, ki jih imajo v povezavi z delom.

Iz izidov raziskav je mogoče razbrati močno povezanost med organizacijsko klimo in zadovoljstvom zaposlenih (npr. Schyns, Veldhoven in Wood 2009), obstankom posameznika na delovnem mestu (npr. Gentry idr. 2007) in namenom posameznika, da zapusti delovno mesto (npr. Sto- 
ne idr. 2007). Organizacijska klima ima močan vpliv na vedenje in obnašanje posameznika. Iz izidov raziskave Hasmina, N. A. Ishak in Hilmija (2015) je razvidno, da je organizacijska klima pozitivno povezana z delovno vpetostjo v organizacijo ter $\mathrm{z}$ zadovoljstvom pri delu.

Organizacijska klima vpliva na produktivnost zaposlenih (npr. Patterson Warr in West 2004) in njihovo socialno interakcijo (npr. Chen in Huang 2007), vendar pa v različnih skupinah zaposlenih ti različno dojemajo svoje delo. Tudi v raziskavi Hasmina, N. A. Ishak in Hilmija (2015) se je pokazala potreba po ustrezni organizacijski klimi s katero se spodbuja zaposlovanje invalidnih oseb.

\section{Organizacijska klima in uspešno staranje zaposlenih}

Organizacijska klima je opredeljena kot skupno dojemanje zaposlenih (politike, norm, postopkov, praks ipd.) v njihovem delovnem okolju (Schneider in Reichers 1983). Nastane z združevanjem psihološke klime oziroma dojemanjem vseh zaposlenih na delovnem mestu (James idr. 2008). Raziskovalci so opredelili več vidikov organizacijske klime, vključno z ustvarjalno klimo (npr. Ekvall i996), varnostno klimo (npr. Neal, Griffin in Hart 2000) in trajnostno klimo (npr. Norton, Zacher in Ashkanasy 20I4). Iz izidov raziskav je razvidno, da je z organizacijsko klimo možno napovedati ustrezen odnos zaposlenih, njihovo vedenje in obnašanje ter učinkvitost organizacije (James idr. 2008; Kuenzi in Schminke 2009).

Organizacijsko klimo, s katero spodbujamo uspešno staranje zaposlenih, definiramo kot skupno dojemanje zaposlenih v obsegu, v katerem jim v njihovi organizaciji omogočajo uspešno staranje (Schneider, Ehrhart in Macey 2013). Med vidike delovnega okolja, s katerimi v organizacijah zaposlenim omogočajo uspešno staranje, prištevamo usmeritve in postopke za enako obravnavo zaposlenih iz različnih starostnih skupin, vzpostavitev skupnih družbenih norm v primeru sprememb, povezanih s starostjo zaposlenih, in upoštevanje posameznih lastnosti (npr. izkušnje) ter osebnih okoliščin (družina, skrbniška odgovornost) pri sprejemanju odločitev, povezanih z delom (Hansson idr. 1997; Thrasher idr. 2016; Hertel in Zacher 2017).

Iz raziskave Zacherja in Gielnika (2014) je razvidno, da vršni managerji »starost zaposlenih« povezujejo $\mathrm{z}$ njihovim odnosom do mladih in starejših zaposlenih kot dojemanje organizacijske klime, ki spodbuja uspešno staranje zaposlenih - kot skupne zaznave skupin mlajših in starejših zaposlenih glede njihovih lastnosti, kot so zanesljivost, produktivnost, ustvarjalnost in prilagodljivost. Povezanost med starostjo vršnih managerjev in organizacijsko klimo, s katero se spodbuja uspešno staranje za- 
poslenih, je bila pozitivna, povezanost med starostjo vršnih managerjev, ki imajo pozitiven odnos do mlajših zaposlenih, in organizacijsko klimo, $s$ katero se spodbuja uspešno staranje zaposlenih, je bila za mlajše zaposlene pozitivna, povezanost med starostjo vršnih managerjev, ki imajo negativen odnos do mlajših zaposlenih, ter organizacijsko klimo, $s$ katero se spodbuja uspešno staranje zaposlenih, pa je bila za mlajše zaposlene negativna.

Iz raziskave Kunzeja, Böhma in H. Bruch (20I I), je razvidno, da je starostna raznolikost zaposlenih pozitivno povezana z organizacijsko klimo. Organizacija, v kateri je prisotna diskriminacija na podlagi starosti, negativno vpliva na organizacijsko pripadnost zaposlenih ter na uspešnost organizacije. Iz raziskave je razvidno tudi, da je starostno raznolika organizacijska klima pozitivno povezana $\mathrm{z}$ učinkovitostjo organizacije in negativno povezana s fluktuacijo zaposlenih.

Iz raziskave Zacherja in Yanga (2016) je razvidno, da je starostno raznolika organizacijska klima pozitivno povezana $\mathrm{z}$ delom ter odnosom posameznikov do različnih učinkov posameznih starostnih skupin zaposlenih.

\section{Organizacijska klima ter varnost in zdravje pri delu}

Zaupanje zaposlenih naj bi razumeli kot prostovoljno odprto občutljivost posameznikov za ostale sodelavce v organizaciji (Rousseau idr. 1998). Zaupanje $\mathrm{v}$ organizaciji (kot npr. zaupanje med sodelavci, zaupanje $\mathrm{v}$ managerje ipd.) predstavlja vplivni dejavnik za spoštovanje varnostnih ukrepov in postopkov, ki so namenjeni načrtovanju in vzdrževanju varnega delovnega okolja (Avram, Ionescu in Mincu 2015). Reason (1997) meni, da naj bi imeli v organizaciji z ustrezno varnostno klimo tudi ustrezen informacijsko-kominikacijski sistem - učinkovita varnost posameznikov naj bi se ustvarjala $\mathrm{z}$ izvajanjem ustreznih postopkov za pridobivanje in sporočanje informacij, ki so povezane $\mathrm{z}$ varstjo in zdravjem pri delu, poštenega motiviranja in pravičnega kaznovanja zaposlenih. Na tak način bodo zaposleni zaupali managerjem, da bodo ti ravnali na pošten način. Po mnenju Burnsa (2005) naj bi v organizaciji za svoje zaposlene izvajali tudi izobraževanje in usposabljanje s področja varnosti in zdravja pri delu - zaposleni naj bi imeli vse potrebne informacije $\mathrm{v}$ zvezi s svojo varnostjo in zdravjem.

V tveganem delovnem okolju (z negativnim dojemanjem varnostne klime) se zmanjšuje raven zadovoljstva pri delu in povečuje stopnja odpovedi delovnega razmerja (Malek, Fahrudin in Kamil 2009). Iz raziskave Avrama, D. Ionescu in Mincuja (2015) je razvidno, da je pozitivno doje- 
manje varnostne klime povezano z visoko stopnjo zadovoljstva pri delu, visoka stopnja zadovoljstva pri delu pa je povezana $\mathrm{z}$ visoko ravnjo zaupanja organizaciji pri zaposlenih.

\section{Organizacijska klima in inovativnost}

Znanje in veščine zaposlenih so ključnega pomena za razvoj inovacij ter konkurenčnih prednosti organizacije (Kissi, Dainty in Liu 20I2). Po mnenju Janssena (2000) inovativno vedenje zaposlenih ni vključeno $\mathrm{v}$ opis delovnih nalog zaposlenega oziroma nima pomembne vloge. Zato je potrebno ustvariti organizacijsko klimo, s katero se bo spodbujalo inovacije (Deshpande in Farley 2004; Patterson, Warr in West 2004; Nybakk in Jenssen 2012).

$\mathrm{Za}$ organizacije, $\mathrm{v}$ katerih spodbujajo inovacije, je značilna visoka stopnja ustvarjalnosti, proaktivnosti in tolerance do tveganja. Na podlagi teh predpostavk so raziskovalci razvili konstrukt, ki so ga imenovali »podjetniško tveganje « in vsebuje omenjene tri dimenzije - inovativnost, proaktivnost in toleranco do tveganja (Covin in Slevin 1989, 1991; Lumpkin in Dess 1996). Podjetniško tveganje pomeni proces zasnove, izvedbe in obvladovanja strategije v organizaciji ter na ravni organizacijskih enot in notranjih organizacijskih praks (De Clercq in Rius 2007; Rauch idr. 2009). Če se podjetniško tveganje odraža v procesih in praksah organizacije, te organizacijske lastnosti prepoznajo zaposleni in tako prispevajo $\mathrm{k}$ razvoju ustrezne organizacijske klime. Taka organizacijska klima po mnenju raziskovalcev (npr. Crespell in Hansen 2009; Nybakk in Jenssen 20I2) vpliva na uspešnost organizacije. Iz številnih raziskav (npr. Janssen, Van de Vliert in West 2004; Kanter 1988; Oldham in Cummings 1996; Scott in Bruce 1994; Yuan in Woodman 2010; Shih in Susanto 201 I) je mogoče razbrati, da inovativno vedenje zaposlenih pomaga organizacijam pri pridobivanju konkurenčne prednosti.

Zasledili smo raziskave, $\mathrm{v}$ katerih so avtorji preučevali organizacijsko klimo, s katero se spodbuja inovativnost, proaktivnost in toleranco do tveganja, kot tudi raziskave, $v$ katerih so posebej preučevali t. i. inovativno organizacijsko klimo (Fischer in Farr 1985; Moolenaar, Daly in Sleegers 2010; Patterson idr. 2005; Scott in Bruce 1994; Van der Vegt, Van de Vliert in Huang 2005; Wang in Rode 2010), proaktivno organizacijsko klimo (Baer in Frese 2003; Fay, Luhrmann in Kohl 2004; Grant in Ashford, 2008; Michaelis, Stegmaier in Sonntag 2010) in tvegano organizacijsko klimo (Ansari, Baumgartel in Sullivan 1982; Ekvall 1996; Ettlie in O'Keefe 1982; Hughes in Morgan 2007). 
Inovativno organizacijsko klimo opredeljujemo kot skupno percepcijo članov organizacije v zvezi s postopki, postopke in vedenje, ki spodbujajo nastanek, razvoj ter realizacijo novih in uporabnih idej (Van der Vegt, Van de Vliert in Huang 2005). V organizacijah z močno razvito inovativno organizacijsko klimo spodbujajo zaposlene, da se učijo od drugih - tako znotraj kot zunaj organizacije (Pillinger in West 1995; Van der Vegt, Van de Vliert in Huang 2005). Iz raziskave Mumforda in S. B. Gustafson (1988) je razvidna pozitivna povezanost med inovativno organizacijsko klimo in individualno ustvarjalnostjo zaposlenih. Iz drugih raziskav (npr. Eisenbeiss, Boerner in Knippenberg 2008; Mathisen, Martinsen in Einarsen 2008) pa je razvidna pozitivna povezanost med inovativno klimo in inovacijami v skupini (timu).

$S$ proaktivno organizacijsko klimo se spodbuja zaposlene, da izkoristijo priložnosti in zasledujejo inovacije ter prevzemajo pobudo. $S$ proaktivno organizacijsko klimo prav tako omogočamo zaposlenim, da v primeru nepričakovanih težav na delovnem mestu ravnajo proaktivno (Baer in Frese 2003; Michaelis, Stegmaier in Sonntag 2010).

Organizacijska klima, s katero se spodbuja obvladovanje tveganja, se nanaša na zaznavanje tveganja $\mathrm{z}$ vidika zaposlenih. $\mathrm{V}$ organizacijah, $\mathrm{v}$ katerih je bila razvita močna organizacijska klima, $s$ katero se je spodbujalo tveganje, je bilo zaposlenim dovoljeno sprejemati odločitve, tudi če niso imeli vseh informacij. $S$ tvegano organizacjsko klimo se spodbuja ustvarjalno delovno okolje, zaposlenim pa omogoča, da njihovi inovativni predlogi ne bodo zavrnjeni zgolj zaradi zapletenosti ali premajhne pomembnosti (Isaksen in Ekvall 20ıо).

\section{Povzetek poglavja}

Organizacijska klima je opredeljena kot skupno dojemanje zaposlenih v svojem delovnem okolju. »Prava « organizacijska klima pozitivno vpliva na učinkovitost organizacije.

$\mathrm{Z}$ organizacijsko klimo, s katero spodbujamo zdravje zaposlenih, vplivamo na izide, ki so povezani z duševnim in s fizičnim zdravjem, pozitivno vplivamo na delovno zmožnost zaposlenih in zmanjšujemo prezentizem ali absentizem. To se odraža $\mathrm{v}$ večji motiviranosti in pripadnosti zaposlenih podjetju ali drugi ustanovi. $\mathrm{Z}$ organizacijsko klimo prav tako pozitivno vplivamo na delovno vpetost invalidnih oseb, njihovo zadovoljstvo pri delu, produktivnost in socialno interakcijo. Zato je dobro, da v organizacijah razvijajo takšno organizacijsko klimo, s katero spodbujajo zaposlovanje invalidnih ali kako drugače hendikepiranih oseb. 
Organizacijsko klimo, s katero spodbujamo uspešno staranje zaposlenih sodelavcev, smo opredelili kot klimo, s katero naj bi podpirali usmeritve in postopke za enako obravnavo zaposlenih različnih starosti, skupne družbene usmeritve, ki jih je mogoče povezati s starostjo zaposlenih (npr. z vidika zanesljivosti, produktivnosti, ustvarjalnosti, prilagodljivosti ipd.), in upoštevali spremembe, ki so povezane $z$ njihovim delom. Starostno raznolika organizacijska klima je pozitivno povezana z učinkovitostjo organizacije in negativno povezana $s$ fluktuacijo zaposlenih. Organizacijska klima, v kateri je prisotna diskriminacija na podlagi starosti, negativno vpliva na pripadnost zaposlenih ter na uspešnost organizacije.

$S$ »pravo« organizacijsko klimo pozitivno vplivamo na varno in zdravo delovno okolje zaposlenih sodelavcev - organizacijska klima, s katero spodbujamo načrtovanje, izvajanje in kontroliranje ustreznih postopkov za sporočanje informacij, je povezana $z$ varnostjo in zdravjem pri delu. S primerno varnostno klimo spodbujamo izvajanje kar najpravičnejših načel in pravil glede motiviranja in spodbujanja zaposlenih sodelavcev. Poudariti velja, da v tveganem delovnem okolju (npr. z negativnim dojemanjem varnostne kulture) zmanjšujemo raven zadovoljstva zaposlenih sodelavcev pri delu in povečujemo stopnjo absentizma ter odpovedi delovnega razmerja.

$\mathrm{Z}$ visoko razvito organizacijsko klimo pozitivno vplivamo tudi na inovativno vedenje in obnašanje zaposlenih, kar se odraža $v$ uspešnosti podjetja in drugih ustanov. $\mathrm{V}$ organizacijah $\mathrm{z}$ močno razvito inovativno klimo spodbujajo zaposlene, da se učijo od drugih, in individualno ustvarjalnost zaposlenih. S proaktivno organizacijsko klimo spodbujamo zaposlene sodelavce, da izkoristijo priložnosti in prevzemajo pobudo. Organizacijska klima, s katero spodbujamo prevzemanje tveganja, se odraža v večji kreativnosti zaposlenih sodelavcev ter v njihovem boljšem sprejemanju odločitev.

\section{Literatura}

Ansari, M. A., H. Baumgartel in G. Sullivan. 1982. »The Personal Orientation-Organizational Climate Fit and Managerial Success.«Human Relations 35 (12): I 159-78.

Avram, E., D. Ionescu in C. L. Mincu. 2015. »Perceived Safety Climate and Organizational Trust: The Mediator Role of Job Satisfaction.« Procedia - Social and Behavioral Sciences I87 (I): 679-84.

Baer, M. in M. Frese. 2003. »Innovation is Not Enough: Climates for Initiative and Psychological Safety, Process Innovations and Firm Performance.«Journal of Organizational Behaviour 24 (I): 45-68. 
Basen-Engquist, K., K. S. Hudmon, M. Tripp in R. Chamberlain. 1998. »Worksite Health and Safety Climate: Scale Development and Effects of a Health Promotion Intervention.« Preventive Medicine 27 (I): I I II9.

Böhm S. A., F. Kunze in H. Bruch. 201 4. »Spotlight on Age-Diversity Climate: The Impact of Age-Inclusive HR Practices on Firm-Level Outcomes.«Journal of Personality and Social Psychology. 67 (3): 667-704.

Burns, C. 2005. »Dual Attitudes about Trust in Safety Culture.« The Business Review 4 (2): 92-98.

Cartwright, S., in C. L. Cooper. 2013. »Towards Organizational Health: Stress, Positive Organizational Behavior, and Employee Well-Being. $\ll$ V Bridging Occupational, Organizational and Public Health, ur. G. F. Bauer in O. Hämmig, 29-42. New York: Springer.

Chen, C., in J. Huang. 2007. »How Organizational Climate and Structure Affect Knowledge Management - The Social Interaction Perspective.«International Journal of Information Management 27 (2): 104-18.

Connelly, B. L., S. T. Certo, R. D. Ireland in C. R. Reutzel. 20 I . »Signaling Theory: A Review and Assessment.«Journal of Management 37 (I): 39-67.

Covin, J. G., in D. P. Slevin. 1989. »Strategic Management of Small Firms in Hostile and Benign Environments.« Strategic Management Journal Iо (I): $75-87$.

Covin, J. G., in D. P. Slevin. 1991. »A Conceptual Model of Entrepreneurship as Firm Behavior.« Enterpreneurship Theory and Practice I6 (I): 7-25.

Crespell, P., in E. Hansen. 2009. »Antecedents to Innovativeness in the Forest Product Industry.« Journal of Forest Products Business Research 6 (I): $\mathrm{I}-20$.

Danna, K., in R. W. Griffin. 1999. »Health and Well-Being in the Workplace: A Review and Synthesis of the Literature.«Journal of Management $25(3): 357-384$.

De Clercq, D., in I. B. Rius. 2007. »Organizational Commitment in Mexican Small Andmedium-Sized Firms: The Role Ofwork Status, Organizational Climate, and Entrepreneurial Orientation.« Journal of Small Business Management 45 (I): 467-90.

Deshpande, R., in J. U. Farley. 2004. »Organizational Culture, Market Orientation, Innovativeness, and Firmperformance: An International Research Odyssey.« International Journal of Research in Marketing 2 I (I): $3-22$. 
Ehrhart, M. G., in S. E. Naumann. 2004. »Organizational Citizenship Behavior in Work Groups: A Group Norms Approach.«Journal of Applied Psychology 89 (6): 960-74.

Eisenbeiss, S. A., S. Boerner in D. V. Knippenberg. 2008. »Transformational Leadership and Team Innovation: Integrating Team Climate Principles.« Journal of Applied Psychology 93 (6): 1438-46.

Ekvall, G. 1996. »Organizational Climate for Creativity and Innovation.« European Journal of Work Organizational Psychology 5 (I): 105-23.

Ettlie, J. E., in R. D. O'keefe. 1982. »Innovative Attitudes, Values, and Intentions in Organizations.«Journal of Management Studies I9 (I): 16382 .

Fay, D., H. Luhrmann in Kohl. 2004. »Proactive Climate in a Post-Reorganization Setting: When Staff Compensate Managers' Weakness.«European Journal of Work Organizational Psychology I3 (2): 24I-67.

Fischer, W. A., in C. M. Farr. 1985. »Dimensions of Innovative Climate in Chinese R \& D Units.« $R$ \& D Management I5 (3): I83-90.

Furuoka, F., B. Lim, K. H. Pazim in R. Mahmud. 20I I. »Employment Situation of Persons with Disabilities: Case Sudies of US, Japan and Malaysia.«Journal of Arts, Science \& Commerce 2 (4): I-IO.

Gentry, W.A., K. W. Kuhnert, S. P. Mandore in E. E. Page. 2007. »The Influence of Supervisory-Support Climate and Unemployment Rate on Part-Time Employee Retention: A Multilevel Analysis.«Journal of Management Development 26 (10): 1005-22.

Grant, A. M., in S. J. Ashford. 2008. »The Dynamics of Proactivity at Work.« Research in Organizational Behavior 28 (I): 3-34.

Hansson R. O., P. D. DeKoekkoek, W. M. Neece in D. W. Patterson D. W. 1997.«Successful Aging at Work: Annual Review, 1992-1996: The Older Workers and Transitions to Retirement.« Journal of Vocational Behavior 5I (2): 202-233.

Hasmin, H., N. A. Ishak in Z. A. G. Hilmi. 2015. »Influence of Organizational Climate on Disabled Job Embeddedness.« Procedia - Social and Behavioral Sciences 202 (I): 242-5I.

Hertel, G., in H. Zacher. 2017. »Managing the Aging Workforce.«V Handbook of Industrial, Work, and Organizational Psychology, ur. N. Anderson, D. S. Ones, C. Viswesvaran in H. K. Sinangil, v tisku. New York: Sage Publications.

Hughes, M., in R. E. Morgan. 2007. »Deconstructing the Relationship between entrepreneurial Orientation and Business Performance at the 
Embryonic Stage of Firmgrowth.« Industrial Marketing Management 36 (I): 65I-6I.

Isaksen, S. G., in G. Ekvall. 2oro. »Managing for Innovation: The Two Faces of Tension in Creative Climates. « Creativity and Innovation Management is (2): 73-88.

James L. R., C. C. Choi, C.-H. E. Ko, P. K. McNeil, M. K. Minton, M. A. Wright in K. I. Kim. 2008. »Organizational and Psychological Climate: A Review of Theory and Research.« European Journal of Work and Organizational Psychology 17 (I): 5-32.

Janssen, O. 2000. »Job Demands, Perceptions of Effort-Reward Fairness and Innovative Work Behaviour.«Journal of Occupational and Organizational Psychology 73 (I): 287-302.

Janssen, O., E. Van de Vliert in M. West. 2004. »The Bright and Dark Sides of Individual and Group Innovation: A Special Issue Introduction.«Journal of Organizational Behavior 25 (I): I29-I45.

Kanter, R. M. 1988. »When a Thousand Flowers Bloom: Structural, Collective and Social Conditions for Innovation in Organizations. $\mathrm{V} R e$ search in Organizational Behaviour, ur. B. M. Straw in L. L. Cummings, I23-67. Greenwich, CT: JAI Press.

Kissi, J., A. R. J. Dainty, A. R. J. in A. Liu. 201 2. »Examining Middle Managers' Influence on Innovation in Construction Professional Services Firms: A Tale of Three Innovations.« Construction Innovation: Information, Process, Management I 2 (I): I I-28.

Kuenzi, M., in M. Schminke. 2009. »Assembling Fragments into a Lense: A Review, Critique, and Proposed Research Agenda for the Organizational Work Climate Literature.«Journal of Management 35 (3): 634-717.

Kunze, F., S. A. Böhm in H. Bruch. 20 I . »Age Diversity, Age Discrimination Climate and Performance Consequences: A Cross Organizational Study.« Journal of Organizational Behavior 32 (2): 264-90.

Lumpkin, G. T., in G. G. Dess. 1996. »Clarifying the Entrepreneurial Orientation Construct and Linking it to Performance.«Academy of Management Review 2 I (I): 135-72.

Malek, M. D., A. Fahrudin in I. S. M. Kamil. 2009. Occupational Stress and Psychological Well Being in Emergency Services. Asian Social Work and Policy 3 (I): I 43-I54.

Mathisen, G. E., O. Martinsen in S. Einarsen. 2008. »The Relationship between Creative Personality Composition, Innovative Team Climate, and Team Innovativeness: An Input-Process-Output Perspective.«Journal of Creative Behavior 42 (I): $13-3 \mathrm{I}$. 
Michaelis, B., R. Stegmaier in K. Sonntag. 2010. »Shedding Light on Follower's Innovation Implementation Behavior: The Role of Transformational Leadership, Commitment to Change, and Climate for Initiative.« Journal of Management Psychology 25 (I): 408-29.

Moolenaar, N. M., A. J. Daly in P. J. C. Sleegers. 2oro. »Occupying the Principal Position: Examining Relationships between Transformational Leadership, Social Network Position, and Schools Innovative Climate.« Education Admistration Quaterly 46 (I): 623-70.

Mumford, M. D., in S. B. Gustafson. 1988. »Creativity Syndrome: Integration, Application, and Innovation.« Psychology Bulletin I03 (I): 27-43.

Neal, A., M. A. Griffin in P. M. Hart. 2000. »The Impact of Organizational Climate on Safety Climate and Individual Behavior.« Safety Science $34(\mathrm{I}-3)$ : 99-109.

Newton, R., M. Ormerod in P. Thomas. 2007. »Disabled People‘s Experiences in the Workplace Environment in England.« Equal Opportunities International 26 (6): 610-23

Norton, T. A., H. Zacher in N. M. Ashkanasy. 20 I 4. »Organisational Sustainability Policies and Employee Green Behaviour: The Mediating Role of Work Climate Perceptions.« Journal of Environmental Psychology 38 (I): 49-54.

Nybakk, E., in J. I. Jenssen. 20I2. »Innovation Strategy, Working Climate, and Financial Performance in Traditional Manufacturing Firms: An Empirical Analysis.« International Journal of Innovation Management I6 (2): I-3O.

Oldham, G. R., in A. Cummings. 1996. »Employee Creativity: Personal and Contextual Factors at Work.« Academy of Management Journal 39 (3): 607-34.

Ostroff, C., in D. E. Bowen. 2000. »Moving HR to a Higher Level: HR Practices and Organizational Effectiveness.«V Multilevel Theory, Research, and Methods in Organizations: Foundations, Extensions, and New Directions, ur. K. J. Klein in S. W. J. Kozlowski, 2 I I-66. San Francisco: Jossey-bass.

Pagan-Rodriguez, P. 2009. »Onset Disability and Life Satisfaction: An Evidence from the German Socio-Economic Panel (GSOEP).« European Journal Health Economic i I (I): 47 I- 85.

Patterson, M. G., P. Warr, P. in M. West. 2004. »Organizational Cimate and Company Productivity: The Role of Employee Affect and Employee Level.« Journal of Occupational and Organizational Psychology 77 (I): 193-216. 
Patterson, M., M. West, V. Shackleton, J. Dawson, R. Lawthom, S. Matlis, D. L. Robinson in A. M. Wallace. 2005. »Validating the Organizational Climate Measure: Links to Managerial Practices, Productivity and Innovation.«Journal of Organizational Behaviour 26 (I): 379-408.

Pillinger, T., in M. A. West. 1995. Innovation in UK Manufacturing Companies. Sheffield: Institute of Work Psychology, University of Sheffield.

Rauch, A., J. Wiklund, G. T. Lumpkin in M. Frese. 2009. »Entrepreneurial Orientation and Business Performance. An Assessment of Past Research and Suggestions for the Future.«Enterpreneurship Theory \& Practice 33 (3): 76I-87.

Reason, J. 1997. Managing the Risks of Organizational Accidents. Aldershot: Ashgate.

Ribisl, K. M., in T. M. Reischl. 1993. »Measuring the Climate for Health at Organizations: Development of the Worksite Health Climate Scales.« Journal of Occupational and Environmental Medicine 35 (I): 8I2-24.

Rousseau, D., S. Sitkin, R. Burt in C. Camerer. I998. »Not so Different After All: A Cross Discipline View of Trust.« Academy of Management Review 23 (2): 393-404.

Schneider, B., in A. E. Reichers. 1983. »On the Etiology of Climates.«Personnel Psychology 36 (I): 19-40.

Schneider, B., M. G. Ehrhart in W. H. Macey. 2013. »Organizational Climate and Culture.« Annual Review of Psychology 64 (I): $36 \mathrm{I}-88$.

Schulz, H., H. Zacher in S. Lippke. 2017. »The Importance of Team Health Climate for Health-Related Outcomes of White-Collar Workers.« Frontiers in Psychology 8 (74). http://journal.frontiersin.org/article/10.3389/fpsyg.2017.00074/full.

Schyns, B., M. V. Veldhoven in S. Wood. 2009. »Organizational Climate, Relative Psychological Climate and Job Satisfaction.«Leadership \& Organization Development Journal 30 (7): 649-663.

Scott, S. G., in R. A. Bruce. 1994. »Determinants of Innovative Behavior: A Path Model of Individual Innovation in the Workplace.« Academy of Management Journal 37 (I): 580-607.

Shih, H., in E. Susanto. 20 I r. >Is Innovative Behavior Really Good for the Firm?: Innovative Work Behavior, Conflict with Co-Workers and Turnover Intention: Moderating Roles of Perceived Distributive Fairness.« International Journal of Conflict Management 22 (2): I I I-30.

Sonnentag, S., in A. Pundt. 2016. »Organisational Health Behavior Climate: Organisations Can Encourage Healthy Eating and Physical Exercise.« Applied Psychology an International Review 65 (I): 259-86. 
Stone, P.W., C. Mooney-Kane, E. L. Larson, D. K. Pastor, J. Zwanziger in A. W. Dick. 2007. »Nurse Working Conditions, Organizational Climate and Intent to Leave ICUs: An Instrumental Variable Approach.« Health Services Research 42 (3): 1085-104.

Svetovna zdravstvena organizacija (World Health Organization). 1948. Preamble to the Constitution of the World Health Organization. Geneva: World Health Organization.

Ta, T. L., in K. S. Leng. 2013. »Challenges Faced by Malaysians with Disabilities in the World of Employment.« Disability, CBR \& Inclusive Development 24 (I): 6-2I.

Tetrick, L. E., in J. M. Peiró. 2016. »Prevention and Promotion.« V The Psychologically Healthy Workplace: Building a Win-Win Environment for Organizations and Employees, ur. M. J. Grawitch in D. W. Ballard, 199-229. Washington: American Psychological Association.

Thrasher, G. R., K. Zabel, K. Wynne in B. B. Baltes. 2016. »The Importance of Workplace Motives in Understanding Work-Family Issues for Older Workers.«Work Aging Retirement 2 (I): I-I I.

Van der Vegt, G. S., E. Van de Vliert in X. Huang. 2005. »Location-Level Links between Diversity and Innovative Climate Depend on National Power Distance.«Academy of Management Journal 48 (6): I I 7 I-82.

Wang, P., in J. C. Rode. 20I0. »Transformational Leadership and Follower Creativity: The Moderating Effects of Identification with Leader and Organizational Climate.«Human Relations 63 (8): I I05-28.

Yuan, F., in R. W. Woodman. 2010. »Innovative Behavior in the Workplace: The Role of Performance and Image Outcome Expectations.« Academy of Management Journal 53 (2): 323-42.

Zacher, H., in M. Gielnik. 2014. »Organizational Age Cultures: The Interplay of Chief Executive Officers' Age and Attitudes toward Younger and Older Employees.« International Small Business journal 32 (I): 327-49.

Zacher, H., in J. Yang. 2016. »Organizational Climate for Successful Aging. « Frontiers in Psychology 7 (I): 1007. 



\section{Melita Moretti}

Za razumevanje notranjega okolja v podjetju ali drugi ustanovi je koristno poznati tako organizacijsko kulturo kot organizacijsko klimo. Če se ozremo v zgodovino njunega poučevanja, ugotovimo, da so hkratne znanstvene razprave o organizacijski klimi in organizacijski kulturi redke in neskladne. Nekateri avtorji (npr. Evan 1968; Fleishman 1953) so bili mnenja, da je organizacijska kultura širši pojem kot organizacijska klima, nekateri drugi (npr. Argyris 1958) pa menijo ravno obratno, namreč da je organizacijska klima širši pojem kot organizacijska kultura. Med raziskovalci smo zaznali tudi neskladnosti, ki izhajajo iz različnih pristopov preučevanja in razumevanja organizacije. Raziskovalci s področja organizacijske klime so npr. veliko bolj pripravljeni priznati vrednost raziskav s področja organizacijske kulture kot pa obratno. Kot primer navajamo raziskovalca Tricea in J. M. Beyer (1993), ki sta organizacijsko klimo zavrnila kot edini »odsev« izkušenj posameznikov v organizaciji. Drugi raziskovalci so npr. podcenjevali vlogo organizacijske klime in jo označili kot $\gg$ prehodno « (Ott 1989), »prepoznavno « (Rousseau 1990) ali »površinsko « (Alvesson in Berg 1992). Naša skupna ugotovitev je, da sta oba preučevana konstrukta $\mathrm{v}$ teorijo, raziskovanje in prakso prispevala različne vidike pestrosti pogledov na organizacijo, vendar sta nekako kot $\gg$ dva pogleda za isto mizo «. S tem dvema konstruktoma so avtorji zgolj raziskovali in razvijali umetnost razumevanja ene izmed nekaterih možnih podob ter narave metofor v organizacijah (Örtenblad, Trehan in Putman 2016). Podobno ugotovitev je prispeval Schein (2000, xxiv-xxv), ko je navajal da je $\gg$ treba razumeti, kaj se v organizacijah dogaja in zakaj ravno na ta način, zato pa je potrebnih več konceptov. Če sta klima in kultura na- 
tančno opredeljeni, potem obe postaneta ključna gradnika za opis organizacije in analiz.«

V prejšnjih poglavjih smo avtorji predstavili vsak konstrukt organizacijske klime in organizacijske kulture posebej, na način, kot je napisana večina strokovne in znanstvene literature s področja organizacijskih znanosti. Namen tega poglavja je na podlagi spoznanj iz predhodnih poglavij osvetliti podobnosti in razlike med obema konstruktoma ter na novo izpostaviti, kako preučevanja oziroma ugotovitve iz obravnave enega konstrukta koristijo drugemu in obratno.

\section{Podobnosti med organizacijsko kulturo in organizacijsko klimo}

Med organizacijsko kulturo in organizacijsko klimo naj bi obstajalo nekaj podobnosti, predvsem $\mathrm{z}$ raziskovalnega vidika. Prva podobnost je ta, da sta tako organizacijska kultura kot organizacijska klima razsežen, večdimenzionalen in večnivojski konstrukt. Druga podobnost je v tem, da se s preučevanjem obeh konstruktov osredinjamo na makro pogled skupnih učinkov posameznikov in njihovega vedenja ter obnašanja v izbranem podetju ali drugi ustanovi (oziroma množici podjetij ali drugih ustanov). Kot tretje, s preučevanjem obeh konstruktov se osredinjamo na notranje okolje podjetja ali druge ustanove in ne na posameznika (Denison 1996). Pri obeh konstruktih se uporabljata različna pristopa preučevanja notranjega okolja organizacije, v izhodišču pa sta podobna. Četrta ključna podobnost med organizacijsko klimo in organizacijsko kulturo je v tem, da naj bi z obema konstruktoma delovali na organizacijo (enoto analize) bolj kot na posameznika. Definicije organizacijske kulture in organizacijske klime zajemajo dejavnike organizacije, v kateri obstajajo skupne zaveze, pomeni in/ali razumevanje. Peta podobnost med obema konstruktoma se nanaša na vloge lastnikov, ustanoviteljev ter managerjev in njihovega planiranja, organiziranja, vodenja in kontroliranja. Tako preučevalci organizacijske klime kot organizacijske kulture osrednjo vlogo pri tem, kakšen konstrukt bo v organizaciji opredeljen in na kakšen način bo vplival na zaposlene sodelavce, pripisujejo lastnikom in managerjem. Ta poudarek je izrazitejši v strokovni literaturi s področja organizacijske kulture - Shein je npr. razpravljal o mehanizmih vgradnje organizacijske kulture in njene krepitve kot o načinih, kako managerji »krepijo svoja lastna prepričanja in vrednote« (Shein 2010, 235) in »učijo svoje organizacije, kako zaznavajo, mislijo, čutijo in se obnašajo v skladu s svojimi zavedni-

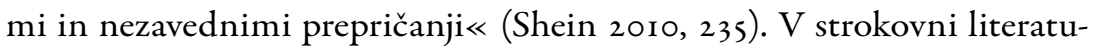
ri s področja organizacijske klime pa se zdi poudarjen pomen lastnikov in managerjev samoumeven. Kot šesto podobnost med organizacijsko 
kulturo in organizacijsko klimo naj omenimo še moč posameznega konstrukta. V strokovni literaturi z obeh področij je razvidno, da se organizacije (ali enote znotraj njih) razlikujejo po moči posameznih konstruktov - to je po obsegu strinjanja posameznikov o prevladujoči organizacijski kulturi ali organizacijski klimi. Kot zadnjo (sedmo) podobnost izpostavimo spoznanje, da sta tako organizacijska kultura kot organizacijska klima povezana z uspešnostjo podjetja ali druge ustanove. Na osnovi predhodnih teoretičnih in empiričnih ugotovitev iz dosedanjega preučevanja obeh konstruktov smo oblikovali preglednico 6.I, v kateri smo povzeli bistvene podobnosti med organizacijsko kulturo in organizacijsko klimo.

Preglednica 6.r: Podobnosti med organizacijsko kulturo in organizacijsko klimo

I Organizacijska kultura in organizacijska klima sta kompleksna, večdimenzionalna in večnivojska konstrukta.

Organizacijska kultura in organizacijska klima se osredinjata na makro pogled skupnih učinkov posameznikov in njihovega vedenja ter obnašanja v organizaciji.

Organizacijska kultura in organizacijska klima se osredinjata na okolje v organizaciji in ne na posameznike.

Organizacijska kultura in organizacijska klima delujeta na organizacijo ali enoto organizacije (na enoto analize) boljkot na posameznike.

5 Vloge ustanoviteljev, lastnikov in managerjev pri oblikovanju konteksta in pomenu v zvezi z njo.

6 Vprašanje moči, ki je pomembna za razumevanje učinkov organizacijske kulture in organizacijske klime.

Povezanost organizacijske kulture in organizacijske klime z uspešnostjo podjetja ali druge ustanove.

\section{Razlike med organizacijsko kulturo in organizacijsko klimo}

Med organizacijsko kulturo in organizacijsko klimo obstajajo razlike. Poudarili bomo predvsem tiste, ki jih je v svojem članku opredelil Denison (1996).

Kot prvo razliko izpostavi teoretična izhodišča konstrukta organizacijske klime in organizacijske kulture ter metodologije njunega raziskovanja. Teoretična izhodišča organizacijske klime naj bi izhajala iz psihologije, za preučevanje pa se je večinoma uporabljala kvantitativna metodologija (vprašalniki, testiranje/merjenje in opazovanje). Teoretične korenine organizacijske kulture naj bi izhajale iz antropologije, medtem ko se je za njeno preučevanje prevladujoče uporabljala kvalitativna metodologija (intervju, opazovanje in metode dnevnika).

Kot drugo razliko izpostavimo časovno usmerjenost obeh konstruktov - organizacijska kultura je bila usmerjena v preteklost ali prihodnost, organizacijska klima pa v sedanje stanje.

Kot tretjo razliko izpostavimo samo zavedanje o organizacijski kulturi ali organizacijski klimi. Organizacijska kultura se pojavlja na nivoju 
odnosov in vrednot in, na svojih najglobljih ravneh, deluje zunaj zavedanja posameznikov $v$ organizaciji - je relativno nevidna in $\mathrm{v}$ podzavesti posameznikov. Schein (2010) npr. navaja, da imajo v podjetju ali drugi ustanovi tako organizacijsko kulturo, ki jo njeni udeleženci takoj »začutijo «. Medtem ko naj bi se organizacijska klima odražala predvsem v okviru posameznikovega zavedanja, je prepoznavnejša in deluje na nivoju odnosov in vrednot - temelji na skupnem zaznavanju udeležencev organizacije o tem, kaj se dogaja z njimi in v njihovi okolici.

Kot četrto razliko izpostavimo prilagodljivost posameznih konstruktov. Kot smo opisali v drugem poglavju, je po mnenju številnih avtorjev (Alvesson in Berg 1992; Deal in Kennedy 1982; Martin in Siehl 1983; Schein 2010) organizacijsko kulturo težko oziroma se postopoma spreminja. Lažje naj bi bilo spreminjati organizacijsko klimo. Tudi če v organizaciji začnejo uvajati korenite spremembe v strateških, taktičnih in izvedbenih postopkih, je za to, da njeni notranji udeleženci sprejmejo in začnejo izvajati nove naloge managerjev, potreben daljši čas.

Preglednica 6.2:Razlike med organizacijsko kulturo in organizacijsko klimo

Teoretična izhodišča in metodologija raziskave: teoretična izhodišča organizacijske klime izhajajo iz psihologije, I za preučevanje se večinoma uporabljajo kvantitativne metode; teoretična izhodišča organizacijske kulture izhajajo iz antropologije, za preučevanje se večinoma se uporablja kvalitativne metode.

Časovna usmerjenost: organizacijska kultura naj bi bila usmerjena v preteklost ali prihodnost, organizacijska klima pa v trenutno stanje.

Zavedanje: organizacijska kultura se pojavlja na nivoju odnosov in vrednot, je relativno nevidna in v podzaves-

3 ti posameznikov. Organizacijska klima deluje v okviru posameznikovega zavedanja, je vidnejša in deluje na nivoju odnosov in vrednot.

4 Prilagodljivost: organizacijsko kulturo je težko spremeniti, organizacijsko klimo pa lažje.

Strateška usmeritev raziskav s področja organizacijske klime; raziskave s področja organizacijske kulture se večinoma ne osredinjajo na »usmerjeno« preučevanje.

Kot peto razliko izpostavimo strateško usmeritev pri posameznem konstruktu. Schneider (1975) je tako npr. zagovarjal trditev, da če je treba napovedati določene izide $\mathrm{v}$ organizaciji, bi bilo pri preučevanju organizacijske klime potrebno opredeliti tiste vidike okolja $\mathrm{v}$ organizaciji, ki so najpomembnejši za napovedovanje teh izidov - preučevale naj bi se npr. zaznave dogodkov, postopkov, pravil, odnosov ipd. Kot primer je navedel sledeče: če sta smoter in cilj izboljšanje kakovosti storitev in višje zadovoljstvo strank, potem je smiselno preučevati storitveno organizacijsko klimo, vključno $\mathrm{z}$ vsemi bistvenimi vidiki postopkov, procesov in praks, ki se nanašajo na zagotavljanje teh storitev (Schneider 1975). Raziskovalci s področja organizacijske kulture se večinoma ne osredinjajo na 
》usmerjeno « preučevanje, saj je preučevanje organizacijske kulture široko (preučuje npr. vrednote, etiko, moralo, norme, načine obnašanja in vedenja ipd.) (Schein 2010). Na osnovi predhodnih teoretičnih spoznanj in ugotovitev empiričnih raziskav smo oblikovali preglednico 6.2, kjer smo strnili razlike med organizacijsko kulturo in organizacijsko klimo.

\section{Kaj se preučevalci posameznega konstrukta lahko naučijo eden od drugega?}

Predhodno smo ugotovili, da med raziskavami organizacijske kulture in organizacijske klime obstajajo podobnosti in razlike $\mathrm{v}$ njunem raziskovanju. Za razumevanje notranjega okolja v organizaciji je dobro poznati tako organizacijsko klimo kot organizacijsko kulturo.

Kaj bi lahko raziskovalci spodročja organizacijske klime izvedeli in se naučli od razmišljanja raziskovalcev na področju organizacijske kulture?

Izpostavili bomo štiri področja širitve raziskovanja organizacijske klime, ki so običajno v domeni raziskovalcev organizacijske kulture, ki pa bi lahko izboljšala konceptualne temelje raziskav in praks s področja organizacijske klime. Kot prvo področje širitve raziskovanja organizacijske klime bi lahko izpostavili večjo osredinjenost na globjo raven psihologije v organizaciji. Z vključitvijo posameznih vprašanj, kot npr. prepričanj in vrednot, ki so običajno v domeni raziskovalcev organizacijske kulture, bi raziskovalci s področja organizacijske klime pridobili dodatne poglede, saj Schein (2010) meni, da so zunanji dejavniki prilagoditve (npr. poslanstvo in vizija ter viri in strategija) pomembni za razumevanje temeljev strateške organizacijske klime, medtem, ko so posamezne predpostavke o notranjem povezovanju, kot npr. jezik, status, porazdelitev moči, status, norme ipd., pomembne za procesno organizacijsko klimo. Raziskovalca varnostne organizacijske klime Zohar in Luria (2005) sta prav tako prišla do ugotovitve, kako je strateško usmerjena varnostna organizacijska klima močno povezana $\mathrm{z}$ različnimi kazalniki učinkovitosti organizacije ugotovila sta npr., da je osredinjenost na ustvarjanje varnostne organizacijske klime močno povezana $\mathrm{z}$ notranjo kakovostjo storitev (kakovost je ena izmed dimenzij organizacijske kulture), ki je potrebna kot podpora tistim posameznikov v organizaciji, ki delajo neposredno s strankami (npr. $\mathrm{v}$ prodajnem oddelku) in $\mathrm{v}$ poprodajnem oddelku (npr. servisu, distribuciji, dostavi).

Kot drugo področje širitve raziskovanja organizacijske klime bi lahko izpostavili večji poudarek na širitev nabora posameznih spremenljivk, ki morebiti vplivajo na organizacijsko klimo, vključno z miti, zgodbami ipd. Raziskovalci organizacijske klime se običajno osredinjajo na politike, pra- 
kse, postopke in sistem nagrajevanja $\mathrm{v}$ organizaciji; raziskovanje organizacijske klime pa naj bi razširili z vključitvijo spremenljivk s področja mitov, zgodb, ritualov, zgodovine organizacije ipd., ki so običajno v domeni raziskovalcev organizacijske kulture - npr. delovna obleka, ureditev delovnega prostora in geografska razpršenost organizacije, naj bi bili po mnenju Ehrharta, Schneiderja in Maceya (2014) povezani z organizacijsko klimo.

Kot tretje področje širitve raziskovanja organizacijske klime izpostavimo raziskovanje širšega vidika zunanjega okolja, $\mathrm{v}$ katerem organizacija deluje, vključno z nacionalno in s transnacinalno kulturo, poklicno kulturo in $\mathrm{z}$ naravo širšega gospodarstva in negospodarstva (npr. stanje v posameznih dejavnostih, stanje $\mathrm{v}$ posameznih lokalnih skupnostih, regijah ipd.) (Schneider, Ehrhart in Macey 2012).

Kot četrto področje širitve raziskovanja organizacijske klime izpostavljamo uporabo tudi kvalitativnih metod raziskovanja (npr. fokusne skupine) in ne samo kvantitativnih (vprašalniki), saj bi na ta način raziskovalci organizacijske klime zajeli večji nabor pomembnih dejavnikov za razumevanje organizacijske klime. Kot dober primer navedimo raziskavo Schneiderja, Ehrharta in Maceyja (1992), ki so s pomočjo Ioo fokusnih skupin intervjuirali udeležence o vrsti izkušenj s storitvami v posamezni podružnice banke in na osnovi analize zapisov ter tekstovnih opisov ugotavljali storitveno klimo v banki - vprašanja za izvedbo fokusne skupine (Schneider, Wheeler in Cox 2013) so bila po mnenju Honga idr. (2013) uporabljena $\mathrm{v}$ mnogih kvalitativnih raziskavah s področja storitvene klime.

Kaj bi labko raziskovalci s področja organizacijske kulture izvedeli in se naučili od razmišljanja raziskovalcev na področju organizacijske klime?

Odgovor na to vprašanje je zapletenejši, saj so raziskovalci pri preučevanju organizacijske kulture $\mathrm{v}$ večini primerov uporabljali kvalitativne metode raziskovanja, vendar pa tudi kvantitativne. Npr., v večini analiziranih primerov raziskav v Sloveniji so avtorji uporabili kvantitativne metode raziskovanja - kot primer navedimo raziskovanje tržne (marketinške) kulture $\mathrm{v}$ različnih podjetjih in ustanovah, $\mathrm{v}$ katerih so uporabili vprašalnik Webster (1995) ter njegove posodobljene in prirejene različice in standardizirani OCAI vprašalnik avtorjev Camerona in Quinna (2006; 20II). V nadaljevanju iskanja odgovorov na zastavljeno vprašanje se bomo tako omejili na raziskave, $\mathrm{v}$ katerih so avtorji preučevali organizacijsko kulturo na splošno, in na raziskave, $\mathrm{v}$ katerih so avtorji preučevali samo organizacijsko kulturo.

Kot prvo področje širitve raziskovanja organizacijske kulture bi izpostavili povečanje preučevanja odnosa med organizacijsko kulturo in 
uspešnostjo podjetja ali druge ustanove. Ne glede na to, da so nekateri raziskovalci preučevali odnos med organizacijsko kulturo in učinkovitostjo podjetja ali druge ustanove (Sackmann 201 I), je po mnenju Ehrharta, Schneiderja in Maceya (2014) čutiti odpor do preučevanja odnosa med organizacijsko kulturo in učinkovitostjo podjetja ali druge ustanove. Avtorji (2014) predpostavljajo, da naj bi vzroki tičali v osredinjenost raziskovalcev na učinkovitost podjetja ali druge ustanove na splošno, kjer so izidi iz raziskav pokazali na omejen vpliv (Alvesson in Berg 1992; Denison 1996; Martin in Frost 1996).

Kot drugo področje širitve raziskovanja organizacijske kulture izpostavljamo uporabo t. i. moderatorjev - to je uporabo dejavnikov, preko katerih naj bi organizacijska kultura imela posreden vpliv na uspešnost podjetja ali druge ustanove. Kot zgleden primer navajamo ugotovitve iz raziskave Gregoryja idr. (2009) o odnosu zaposlenih kot moderatorju vpliva organizacijske kulture na uspešnost ter raziskavo Sørensena (2002) o odnosu nestabilnosti industrijske dejavnosti kot moderatorju učinkov moči organizacijske kulture na uspešnost podjetja ali druge ustanove.

Kot tretje področje širitve raziskovanja organizacijske kulture izpostavljamo priporočilo o sočasni uporabi mešanih metod raziskovanja (kvalitativnih in kvantitativnih). Kot zgleden primer navajamo raziskavo Jermierja idr. (1991), v kateri so raziskovalci izide iz kvantitativne metode raziskave (vprašalniki) dopolnili z rezultati kvalitativne metode zbiranja podatkov (intervjuji).

\section{Povzetek poglavja}

Za razumevanje notranjega okolja v podjetju ali drugi ustanovi je koristno poznavanje tako organizacijske kulture kot organizacijske klime. Med obema konstruktoma obstajajo podobnosti in razlike. Podobnosti med organizacijsko kulturo in organizacijsko klimo so naslednje: ( I) oba konstrukta sta kompleksna, večdimenzionalna in večnivojska; (2) oba konstrukta se fokusirata na makro pogled skupnih učinkov posameznikov in njihovega vedenja ter obnašanja $\mathrm{v}$ organizaciji; (3) z obema konstruktoma se osredinjamo na notranje okolje $\mathrm{v}$ organizaciji in ne na posameznike; (4) z obema konstruktoma se osredinjamo na celotno organizacijo ali na njeno organizacijsko enoto (enoto analize) bolj kot na posameznike; (5) na uveljavljanje obeh konstruktov v organizacii naj bi imeli največji in neposreden vpliv ustanovitelji, lastniki in managerji; (6) oba konstrukta se razlikujeta po moči in vplivu, ki naj bi bila pomembna za razumevanje množice soodvisnih učinkov organizacijske kulture in organizacijske klime v podjetju ali drugi ustanovi; (7) oba konstrukta naj bi bilo mogoče 
(ne vedno) povezati z učinkovitostjo podjetja ali druge ustanove. Prevladujoče razlike med organizacijsko kulturo in organizacijsko klimo so bile naslednje: (I) teoretična izhodišča organizacijske klime naj bi izhajala iz psihologije, za preučevanje so se večinoma uporabljale kvantitative metode zbiranja podatkov, teoretična izhodišča organizacijske kulture pa naj bi izhajala iz antropologije, za preučevanje pa so se večinoma se uporabljale kvalitativne metode zbiranja podatkov; (2) organizacijska kultura naj bi bila usmerjena $\mathrm{v}$ preteklost ali prihodnost, organizacijska klima pa naj bi bila usmerjena na sedanje stanje; (3) organizacijska kultura naj bi se pojavljala na nivoju odnosov in vrednot, je relativno nevidna in $\mathrm{v}$ podzavesti posameznikov; organizacijska klima pa naj bi delovala $\mathrm{v}$ okviru posameznikovega zavedanja, je vidnejša in deluje na nivoju odnosov ter vrednot; (4) organizacijsko kulturo naj bi bilo težje spremeniti kot organizacijsko klimo, vendar oboje ni mogoče izvesti preprosto in hitro; (s) raziskave s področja organizacijske klime so usmerjene v strateške vidike medtem, ko se raziskovalci s področja organizacijske kulture večinoma ne osredinjajo na »usmerjeno « preučevanje.

\section{Literatura}

Alvesson, M., in P. O. Berg. 1992. Corporate Culture and Organizational Symbolism. New York: de Gruyter.

Argyris, C. 1958. »Some Problems in Conceptualizing Organizational Climate: A Case Study of a Bank.« Administrative Science 2uarterly 2 (4): 50I-20.

Cameron, K. S., in R. E. Quinn. 2006. »Diagnosing and Changing Organizational Culture. Based on the Competing Values Framework.« San Francisco: Jossey-Bass.

Cameron, K. S., in R. E. Quinn. 201 r. Diagnosing and Changing Organizational Culture: Based on the Competing Values Framework. San Francisco: Wiley.

Deal, T. E., in A. A. Kennedy. 1982. Corporate Cultures: The rites and Rituals of Corporate Life. Reading: Addison-Wesley.

Denison, D. R. 1996. »What is the Difference between Organizational Culture and Organizational Climate? A Native's Point of View on a Decade of Paradigm Wars.« Academy of Management Journal 2 I (3): 619-654.

Ehrhart, M. G., B. Schneider in W. H. Macey. 2014. Organizational Climate and Culture. New York: Routledge. 
Evan, W. M. 1968. »A System Model of Organizational Climate.« V Organizational climate: Explorations of a concept, ur. R. Tagiuri in G. H. Litwin, I Io-24. Boston: Harvard University.

Fleishman, E. A. 1953. »Leadership Climate, Human Relations Training and Supervisory Behavior.«Personnel Psychology 6 (2): 205-22.

Gregory, B. T., S. G. Harris, A. A. Armenakis in C. L. Shook. 2009. Organizational Culture and Effectiveness: A Study of Values, Attitudes, and Organizational Outcomes. Journal of Business Research 62 (7): 673-679.

Hong, Y., H. Liao, J. Hu in K. Jiang. 2013. »Missing Link in the Service Profit Chain: A Meta-Analytic Review of the Antecedents, Consequences, and Moderators Of Service Climate.« Journal of Applied Psychology 98 (2): $237-67$.

Jermier, J. M., J. W. Slocum, L. W. Fry in J. Gaines. I991. »Organizational Subcultures in a Soft Bureaucracy: Resistance behind the Myth and Façade of an Official Culture.« Organization Science 2 (2): 170-94.

Martin, J., in P. J. Frost. 1996. »The Organizational Culture War Games: A Struggle for Intellectual Dominance.«V Handbook of Organizational Studies, ur. R. Clegg, C. Hardy in W. R. Nord, 599-621. Thousand Oaks: Sage.

Martin, J., in C. J. Siehl. 1983. »Organizational Culture and Counterculture: An Uneasy Symbiosis.« Organizational Dynamics I2 (2): 52-64.

Örtenblad, A., K. Trehan in L. L. Putman. 2016. Exploring Morgan's Metaphors: Theory, Research, and Practice in Organizational Studies. Los Angeles, London, New Delhi, Singapore, Washington, Melbourne: SAGE Publications, Inc.

Ott, J. S. 1989. The Organizational Culture Perspective. Pacific Grove, CA:Brooks-Cole.

Rousseau, D. M. 1990. »Assessing Organizational Culture: The Case for Multiple Methods.«V Organizational Climate qnd Culture, ur. B. Schneider, 153-92. San Francisco: Jossey-Bass.

Sackmann, S. A. 20I I. »Culture and Performance.«V Handbook of Organizational Culture and Climate, ur. N. M. Ashkanasy, C. P. M. Wilderom in M. F. Peterson, I88-224. Thousand Oaks: Sage.

Schein, E. H. 2000. »Sense and Nonsense about Culture and Climate.«V Handbook of Organizational Culture and Climate, ur. N. M. Ashkanasy, C. P. M. Wilderom in M. F. Peterson, xxiii-xxx. Thousand Oaks, CA: Sage.

Schein, E. H. 2010. Organizational Culture and Leadership. San Francisco: Jossey-Bass. 
Schneider, B. 1975. »Organizational Climates: An Essay.« Personnel Psycho$\log y 28$ (4): 447-79.

Schneider, B., M. G. Ehrhart in W. A. Macey. 201 2. »A Funny Thing Happened on the Way to the Future: The Focus on Organizational Competitive Advantage Lost Out.« Industrial and Organizational Psychology: Perspectives on Science and Practice 5 (I): 96-10I.

Schneider, B., J. K. Wheeler in J. F. Cox. 1992. »A Passion for Service: Using Content Analysis to Explicate Service Climate Themes.« Journal of Applied Psychology 77 (5): 705-716.

Sørensen, J. B. 2002. »The Strength of Corporate Culture and the Reliability of Firm Performance.«Administrative Science Quarterly 47 (I): $70-$ 9 I.

Trice, H. M., in J. M. Beyer. 1993. The Cultures of Work Organizations. Englewood Cliffs: Prentice-Hall.

Webster, C. I995. »Marketing Culture and Marketing Effectiveness in Service Firms.« The Journal of Services Marketing, 9 (2): 6-2 I.

Zohar, D., in G. Luria. 2005. »A Multi-Level Model of Safety Climate: Cross-Level Relationships between Organization and Group-Level Climates.« Journal of Applied Psychology 90 (4): 616-28. 
Različni vidiki

organizacijske kulture

in organizacijske klime:

empirične raziskave

v Sloveniji 



\title{
7 \\ Organizacijska kultura \\ v izbrani organizaciji javnega sektorja
}

\author{
Sonja Belac in Mirko Markič
}

Družbeno okolje, v katerem delujejo pridobitne in nepridobitne, javne ali zasebne organizacije, je vse kompleksnejše in turbulentnejše. Spremembe v njem so vsestranske in nepredvidljive, njihova hitrost pa naj bi v prihodnje še naraščala. $V$ razmerah hitrih in dramatičnih sprememb organizacije ne morejo ostati enake za daljše obdobje in pri tem obstati. Izziv zanje ni več, ali se spreminjati, temveč, kako se spreminjati, da bi povečale svojo uspešnost (Cameron in Quinn 2006, 9). Zahtevam dinamičnega družbenega okolja se ne morejo izogniti v nobeni organizaciji, niti v organizacijah $\mathrm{v}$ javni upravi.

$\mathrm{Na}$ nujnost reforme, ki bo pripeljala do sprememb v ustanovah javne uprave, je leta 2008 opozorila tudi OECD v dokumentu »Managing Change in OECD Governments « (Huerta Melchor 2008, 4). Da bi z reformami odgovorili na družbena pričakovanja ob vedno bolj omejenih finančnih sredstvih in političnih pritiskih, v dokumentu izpostavljajo nujo po oblikovanju ustrezne strategije in managementa sprememb. Uspešnost sprememb v organizacijah pa je po Cameronu in Quinnu (2006, 9-I2) odvisna od uspešne spremembe organizacijske kulture. Avtorja na podlagi študij v več tisoč podjetjih in organizacijah ugotavljata, da so v organizacijah po vpeljanih spremembah pogosto $\mathrm{v}$ še slabšem stanju, $\mathrm{v}$ kolikor te ne vključujejo tudi sprememb organizacijske kulture.

Reforme v organizacijah javne uprave so odvisne tudi od prevladujočega pristopa $\mathrm{v}$ teoriji in praksi javne uprave. Tradicionalni pristop je od 8 o. let prejšnjega stoletja spodrival nov javni management (angl. New Public Management - NPM), pojavlja pa se tudi nov pristop. Za njegovo ime še ni soglasja med različnimi avtorji, čeprav v literaturi zasledimo raz- 
lične izraze: nova javna služba (angl. new public service) (Bryson, Crosby in Bloomberg 20I4, 445), vseobsežno/celovito upravljanje (angl. whole-of-government) (Huerta Melchor 2008, Io), novo upravljanje (angl. new governance), dobro upravljanje (angl. good governance) in drugi. Ne glede na vrsto reforme se organizacije $\mathrm{v}$ javni upravi spreminjajo predvsem na podlagi posodobljenega managementa javne uprave, tako da se tradicionalne vrednote spreminjajo $\mathrm{v}$ vrednote nove organizacijske kulture $(\mathrm{Hu}-$ erta Melchor 2008, I4; Pagon, Banutai in Bizjak 2008, 9).

Po pregledu strokovne literature in virov lahko rečemo, da so raziskave s področja organizacijske kulture v javni upravi redke. $\mathrm{Z}$ izvedbo raziskave organizacijske kulture $\mathrm{v}$ izbrani organizaciji javne uprave $\mathrm{z}$ uveljavljenim in standardiziranim vprašalnikom OCAI Camerona in $\mathrm{Qu}-$ inna (2006, 26-28), ki temelji na tipologiji, ki sta jo avtorja imenovala The Competing Values Framework - CVF (Model konkurenčnih vrednot) (Cameron in Quinn 2006, 31), smo tako prispevali k zapolnitvi raziskovalne vrzeli na tem področju.

\section{Namen raziskave}

Namen raziskave je bil ugotoviti obstoječo in želeno organizacijsko kulturo v izbrani organizaciji javne uprave in prisotnost odpora do sprememb ter oblikovati predloge za morebitno izboljšanje.

Iz namena raziskave izhajajo cilji raziskave:

- na populaciji 233 zaposlenih v izbrani organizaciji javne uprave - v Agenciji Republike Slovenije za javnopravne evidence in storitve (AJPES) - ugotoviti obstoječo in želeno organizacijsko kulturo, raziskati, ali ljudje na vodstvenih položajih različno dojemajo organizacijsko kulturo od ostalih zaposlenih, ter ugotoviti, ali zaposleni čutijo odpor do sprememb,

- na podlagi izidov raziskave zasnovati teoretične in praktične smernice za izboljšanje organizacijske kulture v AJPES.

Na podlagi teoretičnih izhodišč, namena in ciljev smo oblikovali hipoteze raziskave.

- Hı: Prevladujoči tip organizacijske kulture je kultura hierarhije.

- $\mathrm{H}_{2}$ : Organizacijska kultura je enaka v vseh organizacijskih enotah.

- $\mathrm{H}_{3}$ : Dojemanje organizacijske kulture vodij je statistično značilno drugačno od dojemanja ostalih zaposlenih.

- $\mathrm{H}_{4}$ : Zaposleni ne čutijo odpora do sprememb. 
$\mathrm{V}$ empiričnem delu raziskave smo $\mathrm{v}$ osnovi uporabili kvantitativno metodo, kot jo opisujejo Easterby Smith, Thorpe in Lowe (2005, 169). Za pridobivanje podatkov in informacij smo uporabili vprašalnik, in sicer že uveljavljen ter standardiziran vprašalnik OCAI Camerona in Quinna (2006, 26-28), ki smo mu dodali še dve vprašanji za ugotavljanje odpora do sprememb, izluščeni iz razmišljanja v delu Huerte Melchorja (Huerta Melchor 2008, 16-20) in delu Pagona, Banutaija in Bizjaka (2008, 20I I). Vse podatke, pridobljene $\mathrm{z}$ anketo, smo ustrezno uredili in obdelali. Najprej smo z metodami opisne statistike preverili lastnosti vzorca in opravili osnovne analize, $s$ katerimi smo določili prevladujočo in želeno organizacijsko kulturo ter odpor do sprememb. Razlike med zaznano obstoječo in želeno organizacijsko kulturo skupno in po posameznih vidikih oziroma vsebinskih področjih organizacijske kulture smo preverili s t-testom dvojic (angl. Paired Samples T-Test). Hipoteze smo preverili $\mathrm{z}$ metodami multivariatne analize: $\mathrm{z}$ analizo variance in $\mathrm{s}$ t-testom za neodvisne vzorce smo preverili razlike v organizacijski kulturi za posamezne organizacijske enote in razlike med vodji ter ostalimi zaposlenimi. $\mathrm{Za}$ obdelavo podatkov smo uporabili programsko opremo SPSS in MS Office Excel.

\section{Opredelitev populacije}

$\mathrm{Na}$ dan 31. I2. 2015 je bilo na AJPES v 13 organizacijskih enotah, centrali in 12 izpostavah v večjih krajih Slovenije zaposlenih 233 delavcev za določen in nedoločen čas, od teh $222,7 \mathrm{~V}$ javni službi in $10,3 \mathrm{v}$ tržni dejavnosti. 78, I \% je bilo žensk, $21,9 \%$ pa moških. Povprečna starost zaposlenega je bila 47 let, $45 \%$ od vseh zaposlenih je bilo starih od 40 do 49 let, $34 \%$ od 50 do 59 let, $18 \%$ od 29 do 39 let in $3 \%$ jih je imelo nad 60 let. I5 \% je imelo srednješolsko izobrazbo, $13 \%$ višješolsko, $27 \%$ visokošolsko, kar $44 \%$ pa univerzitetno ali podiplomsko izobrazbo (»Letno poročilo AJPES za leto $2015 \ll$ ). Po »Pravilniku o notranji organiziranosti in sistematizaciji delovnih mest $\mathrm{v}$ AJPES « vodstvo organizacije sestavljajo direktor, namestnik direktorja in 2 področna sekretarja. Sektorje, službe, izpostave in nekatere oddelke vodijo področni sekretarji ali področni podsekretarji, teh je 32, ostale oddelke pa drugi uslužbenci po pooblastilu direktorja, teh je i3. Zaposlenih na strokovno-tehničnih mestih je 66, ostali, razen direktorja in njegovega namestnika, pa so sodelavci, ki opravljajo naloge javne službe oziroma so na delovnih mestih vodij finančno-računovodske, pravne in kadrovske službe ter službe za informacijske sisteme. V anketiranje smo vključili vse zaposlene sodelavce izbrane organizacije javne uprave. 


\section{Vprašalnik}

Za pridobivanje podatkov in informacij smo uporabili vprašalnik, in sicer že uveljavljen ter standardiziran vprašalnik OCAI Camerona in Quinna (2006, 26-28). Vprašalnik temelji na tipologiji, ki sta jo Cameron in Quinn imenovala $\gg$ The Competing Values Framework - CVF $\ll$ (Model konkurenčnih vrednot) in na podlagi katere sta določila štiri glavne tipe organizacijskih kultur (prav tam, 3I). Za ugotavljanje odpora do sprememb smo $k$ vprašalniku dodali še dve vprašanji, izluščeni iz razmišljanja v delih Huerte Melchorja (Huerta Melchor 2008, 16-20) ter Pagona, Banutaija in Bizjaka (2008, 201 I).

Vprašalnik je sestavljen iz dveh delov. Prvi del vprašalnika se nanaša na standardiziran vprašalnik OCAI, ki je sestavljen iz šestih sklopov $s$ štirimi trditvami, prirejenimi po vprašalniku v knjigi Diagnosing and Changing Organisational Culture (Cameron in Quinn 2006, 26-28), ki ocenjujejo organizacijsko kulturo AJPES. Anketiranci so v stolpcu trenutno stanje razvrstili skupno Ioo točk med trditve posameznega sklopa, tako da so po njihovi presoji kar najbolje odražale trenutno stanje v organizaciji. Enako so ponovili v nadaljevanju v stolpcu želeno stanje, pri čemer so označili tisto, za kar so želeli, da bi v organizaciji veljalo.

PRIMER: Če je nekdo bil mnenja, da trditev A najbolje opisuje stanje $\mathrm{v}$ organizaciji, trditvi $\mathrm{B}$ in $\mathrm{C}$ tudi, a manj kot $\mathrm{A}$, trditev $\mathrm{D}$ pa komaj ustreza opisu stanja, je lahko razdelil točke na naslednji način: $A=55$ točk, $\mathrm{B}$ in $\mathrm{C}=$ vsaka 20 točk, $\mathrm{D}=\varsigma$ točk. To predstavlja skupno Ioo točk.

Temu delu sta dodani dve vprašanji, vezani na odpor do sprememb. Drugi del pa se nanaša na splošne podatke o anketirancu (spol, starost, vrsta zaposlitve, lokacija dela).

\section{Zbiranje podatkov}

Pred izvedbo raziskave smo pridobili pisno soglasje direktorice AJPES. Za zbiranje podatkov in informacij smo uporabili anketni vprašalnik z vprašanji zaprtega tipa in enim kombiniranim vprašanjem. Vse vodje izpostav in vodstvo $\mathrm{v}$ centrali so bili telefonsko obveščeni o tem, da jim bodo $\mathrm{v}$ tajništvo poslane ankete, pojasnjen je bil namen raziskave in odgovorjeno je bilo na vsa vprašanja $\mathrm{v}$ zvezi $\mathrm{z}$ anketo. Anketni vprašalnik $s$ spremnim dopisom za vsakega zaposlenega je bil v izpostavo Maribor posredovan $\mathrm{v}$ skladu $\mathrm{s}$ telefonskim pogovorom $\mathrm{z}$ vodjo izpostave po elektronski pošti I 8. I. 2016, vodja pa je vprašalnike natisnila in jih razdelila vsem sodelavcem. Vprašalniki s spremnim dopisom za vsakega zaposlenega za izpostavo Koper so bili v skladu $\mathrm{z}$ dogovorom $\mathrm{z}$ vodjo izpostave osebno odneseni vodji izpostave Koper 20. I. 2016, ki je vprašalnike raz- 
delil vsem sodelavcem. V ostale izpostave in na centralo so bili vprašalniki s spremnim dopisom za vsakega zaposlenega in s spremnim dopisom za tajništvo posredovani po pošti z navadno pošiljko I9. I. 2016. Tajništva so razdelila ankete ostalim zaposlenim. Anketiranje se je izvajalo en mesec, do 19. 2. 2016 , med tem časom smo določene organizacijske enote spodbudili telefonsko, da nam posredujejo izpolnjene ankete.

\section{Rezultati raziskave}

Sledi analiza strukture vzorca, predstavitev ocene stanja trenutne organizacijske kulture in želene organizacijske kulture ter razlik med percepcijo trenutnega stanja in želeno organizacijsko kulturo, analiza glede na vrsto zaposlitve in lokacijo dela ter analiza odpora do sprememb. Poglavje zaključujemo z razlago izidov in s preverjanjem hipotez ter predlogi za izboljšanje.

\section{Analiza strukture vzorca}

Prejeli smo 102 rešena vprašalnika iz vseh trinajstih organizacijskih enot, med temi je bil eden nepravilno izpolnjen, tako da smo v nadaljnji obravnavi upoštevali samo ıo v prašalnik, kar predstavlja 43,35 \% celotne populacije. V vzorcu je največ anket iz izpostave Ljubljana (2 I,8 \%), centrale $(18,8 \%)$ in izpostave Maribor $(13,9 \%)$, najmanj pa iz izpostave Nova Gorica (I \%), izpostave Postojna (2 \%) in izpostave Trbovlje (2 \%), kar pa ustreza tudi sliki v populaciji, saj je največ zaposlenih AJPES v centrali in izpostavah Ljubljana in Maribor, najmanj pa v izpostavi Postojna, Trbovlje in Krško (»Zapisnik 13. seje kolegija AJPES $2015 \ll, 31$ ). Vprašalnik je izpolnilo 77 \% žensk in $23 \%$ moških v $67,7 \%$, starih od 36 do 55 let, kar ravno tako ustreza sliki celotne populacije (preglednica 7.I). Vodilni zaposleni so v vzorcu zastopani v i6,8 \% ter iz vseh organizacijskih enot z izjemo ene izpostave. Kljub temu, da poznamo populacijsko strukturo in ocenjujemo, da je struktura vzorca podobna populacijski, pa to ni zadosten pogoj, da bi lahko izide raziskave, pridobljene iz vzorca, nekritično posplošili na populacijo. Za posploševanje sta namreč potrebna dva pogoja: reprezentativnost in verjetnost (naključnost vzorca). Ker je naš vzorec priložnostni, lahko ob ocenjeni reprezentativnosti vzorca zgolj trdimo, da so rezultati raziskave morda podobni populacijskim, neposredno posploševanje pa ni možno. 
Preglednica 7.r: Demografski podatki anketiranih oseb

\section{SPREMENLJIVKA}

\section{DESKRIPTOR}

\section{$\%$}

ZAPOSLITEV

vodstveni kader

16,8

\begin{tabular}{lll} 
& nivodstveni kader & 83,2 \\
\hline \multirow{3}{*}{ SPOL } & moški & 23,0 \\
\cline { 2 - 3 } & ženski & 77,0 \\
\hline
\end{tabular}

STAROST

od 25 do 35 let $\quad 9,1$

\begin{tabular}{ll}
\hline od 46 do 55 let & 32,3 \\
\hline več kot 55 let & 23,2 \\
\hline centrala & 18,8 \\
\hline Ljubljana & 21,8 \\
\hline Celje & 5,9 \\
\hline Koper & 6,9 \\
\hline Kranj & 4,0 \\
\hline Krško & 5,0 \\
\hline Maribor & 13,9 \\
\hline Murska Sobota & 5,9 \\
\hline Nova Gorica & 1,0 \\
\hline Novo mesto & 4,0 \\
\hline Postojna & 2,0 \\
\hline Trbovlje & 2,0 \\
\hline Velenje & 8,9 \\
\hline
\end{tabular}

\section{Analiza percepcije trenutne organizacijske kulture}

Rezultati analize kažejo (slika 7.I), da je prevladujoči tip organizacijske kulture v AJPES hierarhija (vrednost $=36,86$ ), sledijo organizacijska kultura tipa klan ali skupina (vrednost $=23,92)$, tipa trg $($ vrednost $=23,78)$ in tipa adhokracija (vrednost $=15,29)$. Pri tem je vrednost posameznega tipa organizacijske kulture pri percepciji trenutnega stanja in želenega stanja izračunana kot povprečna skupna vsota točk po posameznih tipih organizacijskih kultur. Posamezne točke iz vprašalnika OCAI vprašalnika, ki so jih anketiranci dodelili odgovorom A, B, C in D po posameznih šestih sklopih oziroma vidikih ali vsebinskih področjih organizacijske 
kulture, smo namreč ločeno sešteli ter delili s šest (Cameron in Quinn 2006, 26-30).
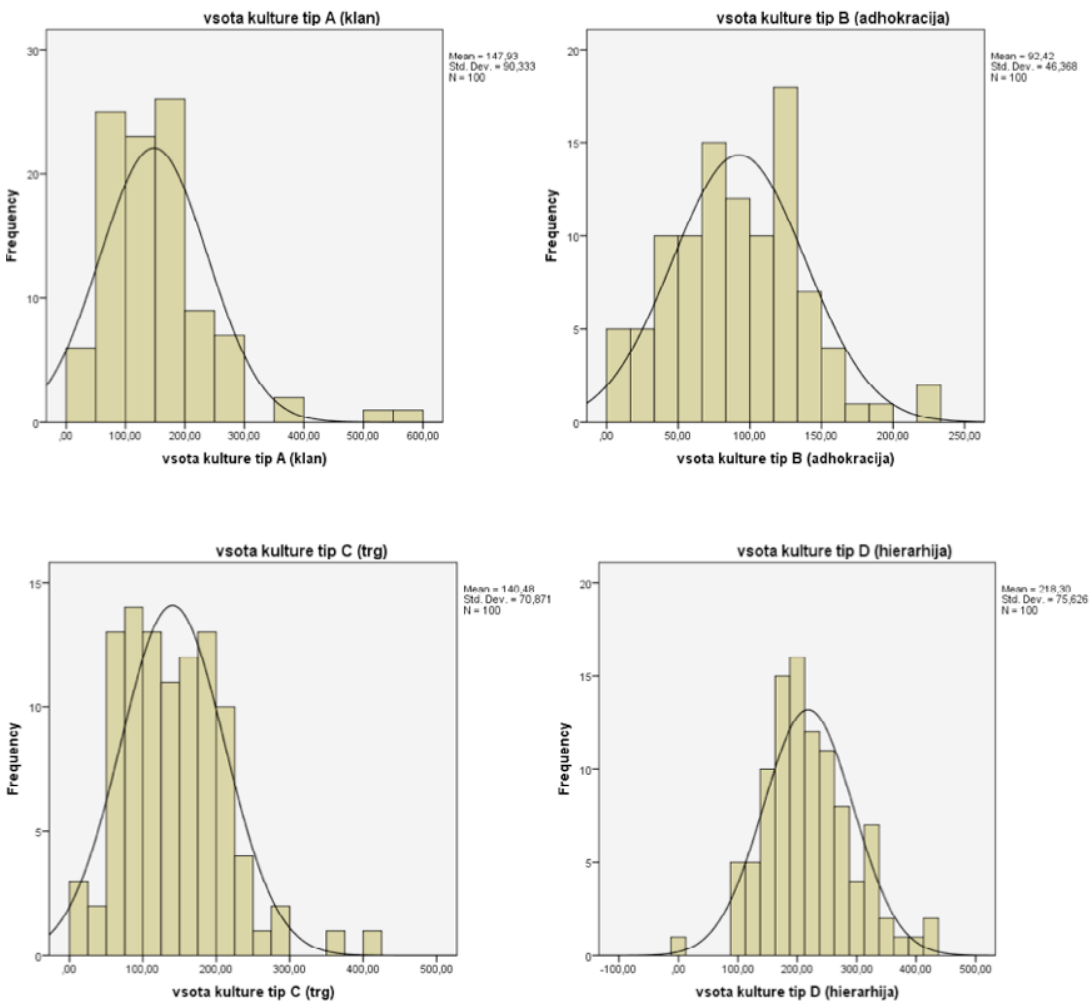

Slika 7.I : Histagrami s prikazom frekvenčne porazdelitve podatkov zaznave trenutnega sta-
nja po posameznih tipih organizacijskih kultur

$\mathrm{Na}$ sliki 7.2 so $s$ histogrami predstavljene frekvenčne porazdelitve podatkov po posameznih tipih organizacijskih kultur za zaznano stanje (spremenljivke, poimenovane vsota kulture tip A, B, C in D). Tako so podatki za hierarhijo in adhokracijo, kar se tiče simetričnosti, blizu normalne porazdelitve, podatki za oceno trenutnega stanja organizacijske kulture tipa klan in tipa trg pa kažejo asimetričnost $\mathrm{v}$ desno (koeficient asimetričnosti za klan $=1,8$ in za trg $=0,7)$. Vse krivulje zaznave trenutnega stanja so nekoliko koničaste (glede na koeficient sploščenosti), bolj zgoščene okrog modusa kot pri normalni porazdelitvi.

Kot kaže preglednica 7.2, organizacijska kultura v AJPES ni usklajena v vseh njenih vidikih oziroma na vsebinskih področjih, saj vodi- 
teljstvo $\mathrm{v}$ organizaciji in način ravnanja $\mathrm{z}$ zaposlenimi kažeta značilnosti drugačne organizacijske kulture - tipa trg in tipa klan. Usklajenost posameznih vidikov organizacijske kulture s prevladujočo skupno organizacijsko kulturo je po Cameronu in Quinnu pomembna, saj so po raziskavah avtorjev organizacije s skladno organizacijsko kulturo uspešnejše (2006, 60). Izidi raziskave kažejo, da je v AJPES prevladujoča taka organizacijska kultura, kot je značilna za klasično obliko javne uprave, glede na Webrova teoretična izhodišča o birokratski upravi. Po oceni zaposlenih je delovno okolje v AJPES zelo nadzorovano in strukturirano, ljudje se morajo pri opravljanju svojega dela držati formalnih postopkov in pravil. Formalna pravila in usmeritve so tisto, kar povezuje zaposlene. Najpomembnejša naloga je vzdrževanje stabilnega delovanja organizacije. AJPES po mnenju zaposlenih namreč poudarja stabilnost in trajnost delovanja, pomembna sta učinkovitost in vzdrževanje nadzora ter delovanja brez motenj. Organizacija svojo uspešnost opredeljuje na osnovi učinkovitosti. Ključno je sistematično načrtovanje dela in $s$ tem čim manjša poraba sredstev. Po mnenju zaposlenih so značilnosti voditeljstva takšne, ki kažejo na tržno naravnanost, saj menijo, da je vodstvo zgled dobrega, agresivnega in na rezultat osredotočenega managementa, način ravnanja z zaposlenimi pa takšen, ki ima povečini značilnosti organizacijske kulture tipa klan, saj so timsko delo, iskanje soglasja in sodelovanje glavne značilnosti stila vodenja v oranizaciji. Sicer pa v obeh vidikih oziroma na vsebinskih področjih organizacijske kulture (voditeljstvo $\mathrm{v}$ organizaciji in način ravnanja) prevladujočima organizacijskima kulturama tesno sledi organizacijska kultura tipa hierarhija.

Preglednica 7.2: Prevladujoči tip organizacijske kulture glede na različne vidike organizacijske kulture

Posamezni vidik organizacijske kulture

Prevladujoči tip organizacijske kulture

temeljne značilnosti delovnega okolja hierarhija

\begin{tabular}{ll}
\hline voditeljstvo v organizaciji & $\operatorname{trg}$ \\
\hline način ravnanja s sodelavci & klan \\
\hline vezi v organizaciji & hierarhija \\
\hline strateški poudarki & hierarhija \\
\hline sodila za uspešnost & hierarhija
\end{tabular}




\section{Želeno stanje}

Zaposleni si želijo po vseh vidikih oziroma vsebinskih prodročjih in skupno (vrednost $=39,47$ ) organizacijsko kulturo tipa klan oziroma skupina. Zanjo velja, da je organizacija prijazno delovno okolje, kjer se udeleženci počutijo kot v družini in si delijo dobro ter zlo. Vodje so mentorji, podpirajo in skrbijo za zaposlene ter so spodbujevalci sodelovanja, organizacijske predanosti in lojalnosti. Pomembne so pripadnost in tradicija ter zavzetost ljudi. Dolgoročno so pomembni razvoj ljudi, povezovanje in moralno delovanje. Uspešnost je odvisna od organizacijske klime in skrbi za ljudi. Poglavitni so timsko delo, sodelovanje in soglasje. Zunanji udeleženci organizacije so v vlogi partnerjev. Na drugem mestu sledi organizacijska kultura tipa hierarhija (vrednost $=27,55)$, potem pa adhokracija $($ vrednost $=18,84)$ in $\operatorname{trg}($ vrednost $=14)$.
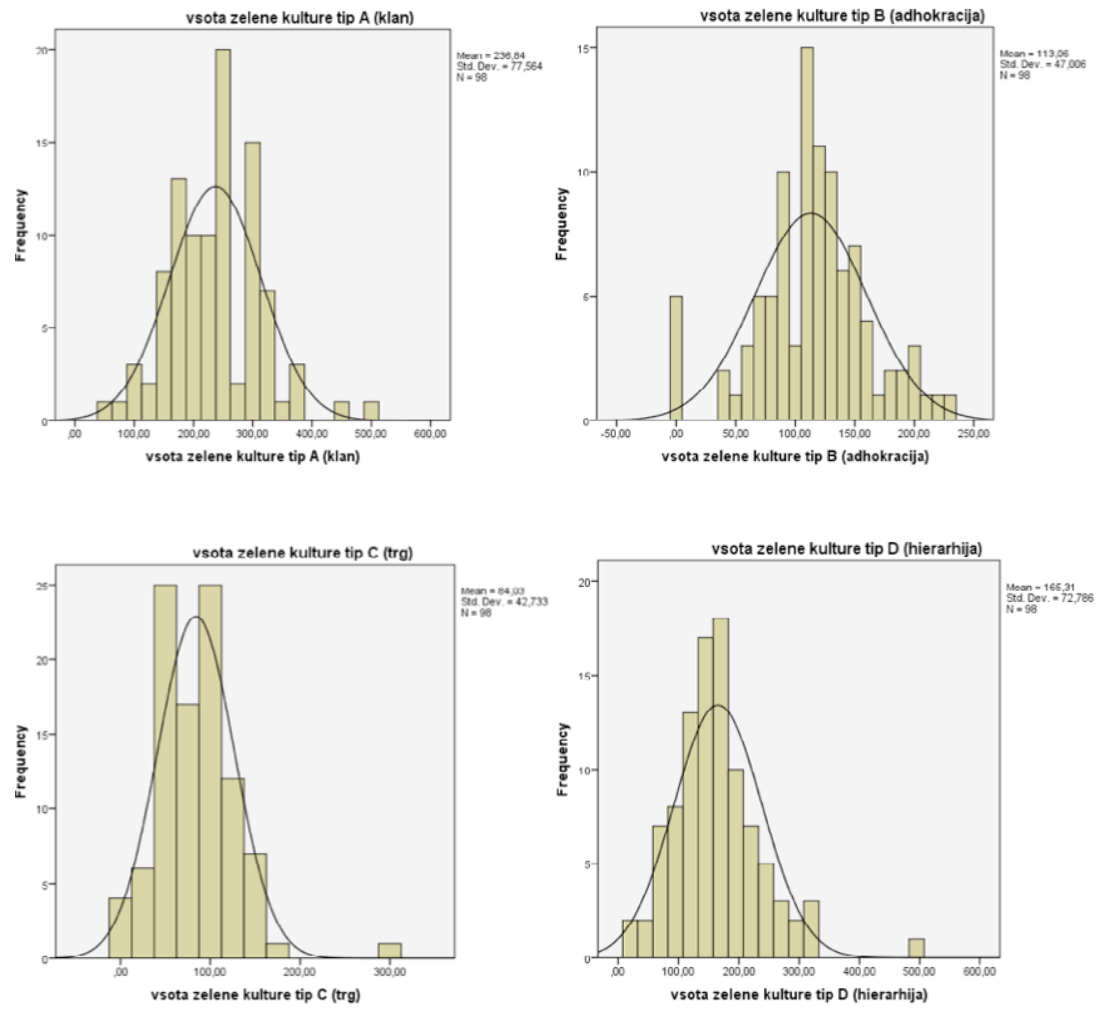

Slika 7.2: Histagrami s prikazom frekvenčne porazdelitve podatkov želenega stanja po posameznih tipih organizacijskih kultur 
Na sliki 7.2 so $s$ histogrami predstavljene frekvenčne porazdelitve podatkov po posameznih tipih organizacijskih kultur za želeno stanje (spremenljivke, poimenovane vsota želene kulture tip A, B, C in D). Tako so podatki za klan in adhokracijo, kar se tiče simetričnosti, blizu normalne porazdelitve, podatki za želeno organizacijsko kulturo tipa hierarhija in tipa trg pa kažejo asimetričnost $\mathrm{v}$ desno (koeficient asimetričnosti za hierarhijo $=1,2$ in za trg = 1,2 ). Vse krivulje želenega stanja so nekoliko koničaste (glede na koeficient sploščenosti), bolj zgoščene okrog modusa kot pri normalni porazdelitvi.

\section{Razlike}

Ko imamo izdelan grafični profil organizacijske kulture in profil posameznih atributov (slike 6 do I I), se lahko lotimo interpretacije z različnih perspektiv, in sicer $\mathrm{z}$ vidika dominantne kulture organizacije, $\mathrm{z}$ vidika odstopanj med trenutno in želeno organizacijsko kulturo, z vidika moči organizacijske kulture, ki je trenutno dominantna, z vidika ujemanja profila posameznih atributov organizacijske kulture tudi glede na različne skupine oziroma organizacijske udeležence, $\mathrm{z}$ vidika primerjave $s$ profilom tipske organizacijske kulture v svoji dejavnosti, z vidika trendov, ki jih avtorja navajata na podlagi svojih raziskav (Cameron in Quinn 2006, 69-7I).

Ugotavljali smo razlike med oceno organizacijske kulture o trenutnem stanju in želeno organizacijsko kulturo. Razlike smo preverjali $s$ t-testom dvojic (Paired - samples t-test). Med percepcijo obstoječe organizacijske kulture in želeno organizacijsko kulturo smo ugotovili statistično značilne razlike pri vseh štirih tipih organizacijskih kultur, in sicer (preglednica 7.3):

- organizacijska kultura tipa klan: anketirane osebe si v prihodnje želijo bistveno več organizacijske kulture tipa klan - razlika je $-15,56$ (vse, kar se razlikuje za Io in več točk, je po Cameronu in Quinnu pomembno odstopanje $(2006,74))(\mathrm{t}=-1 \mathrm{I}, 24$; Sig. = $0,000)$;

- organizacijska kultura tipa adhokracija: anketirane osebe si v prihodnje želijo več inovativnosti, dinamičnosti, ustvarjalnosti in podjetnosti in so pripravljene $\mathrm{v}$ ta namen prevzeti več tveganja $(\mathrm{t}=-4, \mathrm{I} 7$; Sig. $=0,000)$;

- organizacijska kultura tipa trg: anketirane osebe si v prihodnosti želijo občutno manj usmerjenosti na izid in agresivnosti vodstva; 
tekmovalnost, visoke zahteve in dosežki naj ne bodo na prvem mestu $(t=8,80$; Sig. $=0,000)$;

- organizacijska kultura tipa hierarhija: anketirane osebe si v prihodnje želijo manj nadzora, formaliziranosti in strukturiranosti $(\mathrm{t}=7,22 ;$ Sig. $=0,000)$.

Preglednica 7.3: Primerjava obstoječe in želene organizacijske kulture - skupni izid

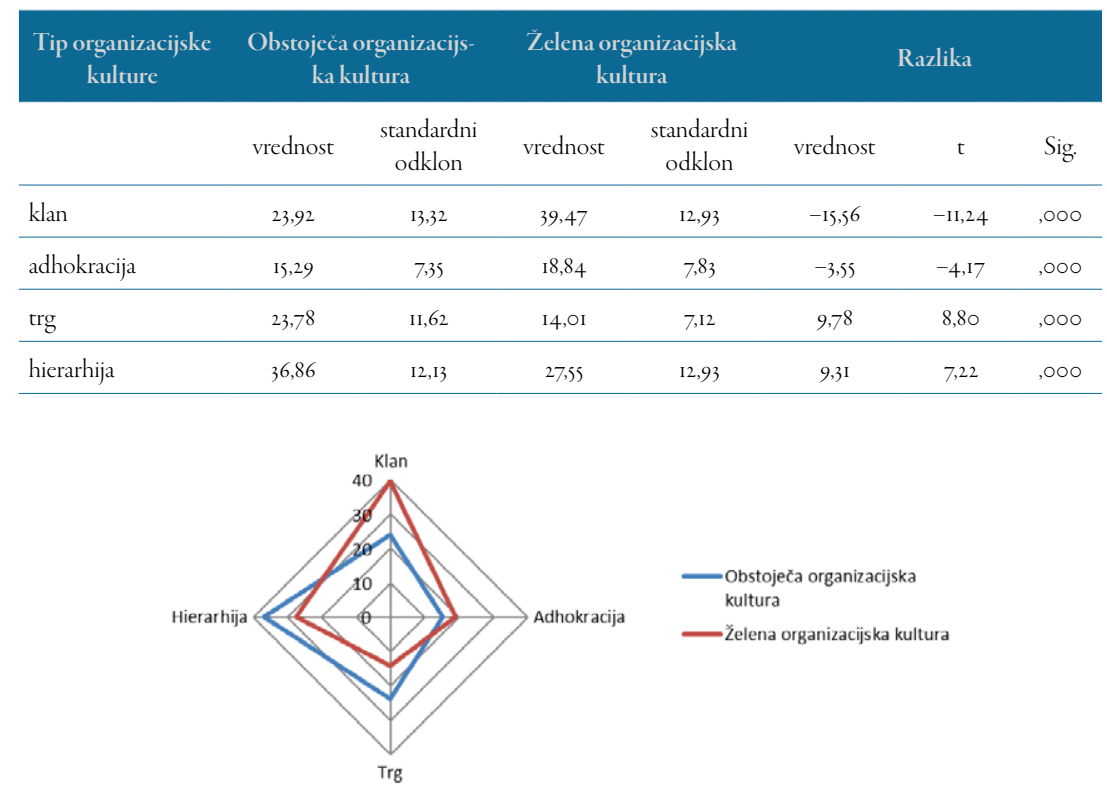

Profil organizacijske kulture AJPES (slika 7.3) je primerljiv tudi s profilom kulture organizacij v javni upravi, ki sta ga predstavila Cameron in Quinn, kjer prevladuje organizacijska kultura tipa hierarhija, organizacijska kultura tipa klan in tipa trg sta zastopani v manjši meri, najmanj pa je prisotna organizacijska kultura tipa adhokracija. Nizka ocena organizacijske kulture tipa adhokracija je po avtorjih običajen pojav. Navajata tudi, da se organizacije skozi čas nagibajo k spodnjima dvema kvadrantoma, ki tudi vztrajata najdlje. Premik iz organizacijske kulture tipa hierarhija in tipa trg $\mathrm{v}$ tip klan in tip adhokracija pa predstavlja za management velik izziv, saj je za to potreben velik napor (Cameron in Quinn 2006, 69-8I). Po Cameronu in Quinnu pa se prevladujoča organizacijska kultura hierarhije $\mathrm{v}$ organizacijah javne uprave ne ujema s prevladujočim novim pristopom $\mathrm{v}$ javni upravi v Sloveniji, to je $\mathrm{z}$ dobrim upravljanjem, kjer 
so v ospredju drugačne vrednote. Sicer pa tipologija konkurenčnih vrednot razkriva sobivanje različnih vrednot, kultur v posamezni organizaciji in omogoča tudi presojo o jakosti posamezne kulture ali pa o uravnoteženosti kultur.

Avtorja navajata, da večje, kot je število točk posameznega tipa organizacijske kulture, večja je jakost, dominantnost tega tipa kulture. Presoja, ali je za organizacijo bolje imeti močan posamezen tip organizacijske kulture ali pa uravnoteženost različnih kultur, je odvisna tudi od zunanjenga okolja, v katerem organizacija deluje. Grafični profil organizacijske kulture AJPES (slika 7.4) kaže na odstopanje organizacijske kulture tipa hierarhija, ostale tri vrste organizacijske kulture pa so zastopane $\mathrm{v}$ manjši meri. Po Malbašiću (2015, XV) so organizacije z uravnoteženimi organizacijskimi vrednotami na splošno uspešnejše od organizacij z neuravnoteženimi vrednotami.

Ugotavljali smo tudi razlike med percepcijo trenutnega stanja in želenim stanjem po posameznih vidikih oziroma vsebinskih področjih organizacijske kulture. Razlike smo preverjali s t-testom dvijic (Paired samples t-test).

Temeljne značilnosti delovnega okolja smo ugotavljali na podlagi odgovorov prvega sklopa vprašanj iz vprašalnika. Izidi prvega sklopa vprašanj, ki se nanašajo na zaznano in želeno organizacijsko kulturo pri temeljnih značilnostih delovnega okolja, so prikazani na sliki 7.4. Po mnenju anketiranih oseb v AJPES prevladuje delovno okolje z značilnostmi organizacijske kulture tipa hierarhija (vrednost $=44,04$ ), za katerega sta značilni nadzorovanost in strukturiranost ter da se ljudje morajo držati formalnih postopkov in pravil pri opravljanju svojega dela. Sledi ji organizacijska kultura tipa trg (vrednost $=22,17)$, tipa klan (vrednost $=$ $21,24)$ in tipa adhokracija (vrednost $=12,45)$.

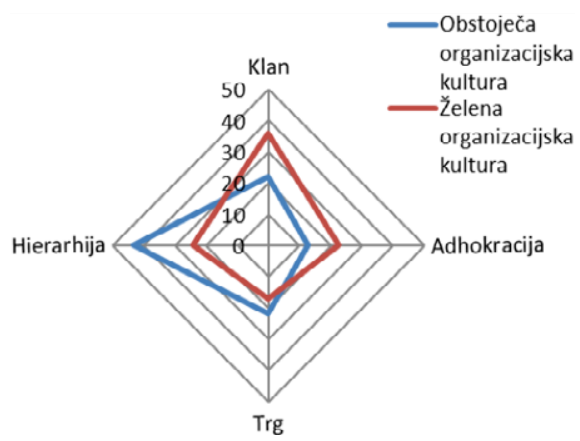

Slika 7.4: Grafični prikaz profila zaznane in želene organizacijske kulture pri temeljnih značilnostih delovnega okolja 
Anketirane osebe si v prihodnje želijo delovnega okolja, v katerem bi prevladovala organizacijska kultura tipa klan (vrednost $=35,86)$ oziroma delovnega okolja, za katerega velja, da je zelo oseben prostor, kjer se ljudje počutijo kot v družini in med seboj zelo dobro sodelujejo. Sledijo organizacijska kultura tipa hierarhija (vrednost $=24,39$ ), tipa adhokracija (vrednost $=22,37)$ in tipa $\operatorname{trg}($ vrednost $=17,07)$.

Pri tem vidiku organizacijske kulture smo med obstoječo in želeno organizacijsko kulturo ugotovili statistično značilne razlike pri vseh štirih tipih organizacijskih kultur:

- organizacijska kultura tipa klan: anketirane osebe si v prihodnje želijo večjega medsebojnega sodelovanja in povezanosti $(t=$ $-7,57$; Sig. = o,o00);

- organizacijska kultura tipa adhokracija: anketirane osebe si v prihodnje želijo več inovativnosti, dinamičnosti, ustvarjalnosti in podjetnosti ter so pripravljene $\mathrm{v}$ ta namen prevzeti več tveganja $(t=-6,99$; Sig. $=0,000)$;

- organizacijska kultura tipa trg: anketirane osebe si v prihodnosti želijo manj usmerjenosti $v$ izid in tekmovalnosti $(t=3,23$; Sig. $=$ $0,002)$;

- organizacijska kultura tipa hierarhija: anketirane osebe si v prihodnje želijo bistveno manj nadzora, strukturiranosti in manj pravil ter postopkov pri opravljanju svojega dela $(t=8,47$; Sig. $=$ $0,000)$.

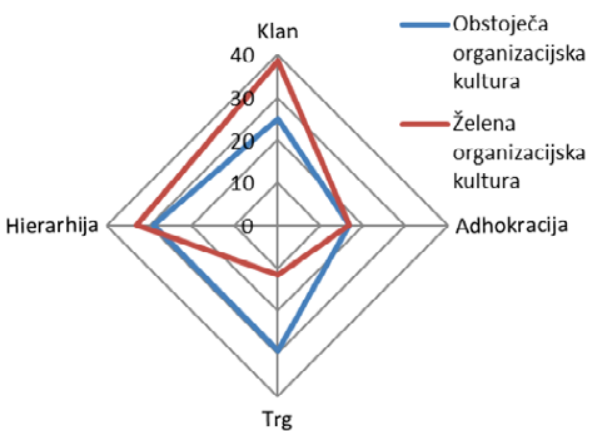

Slika 7.5: Grafični prikaz profila zaznane in želene organizacijske kulture pri voditeljstvu v AJPES

Značilnosti voditeljstva $v$ AJPES smo ugotavljali na podlagi odgovorov drugega sklopa vprašanj iz vprašalnika. Izidi drugega sklopa vpra- 
šanj, ki se nanašajo na zaznano in želeno organizacijsko kulturo pri voditeljstvu v AJPES, so prikazani na sliki 7.5. Po mnenju anketiranih oseb v AJPES prevladuje voditeljstvo z značilnostmi organizacijske kulture tipa $\operatorname{trg}($ vrednost $=29,80)$, za katerega sta značilni usmerjenost na rezultate in agresivnost. Sledijo značilnosti organizacijske kulture tipa hierarhija $($ vrednost $=29,29)$, tipa klan (vrednost $=24,24)$ in adhokracija (vrednost $=16,62)$.

Anketirane osebe si v prihodnje želijo voditeljstva, ki bi v največji meri kazalo značilnosti organizacijske kulture tipa klan (vrednost $=$ 38,43 ) oziroma voditeljstva, ki bi bilo zgled dobrega svetovanja (mentoriranja), podpiranja in skrbi za zaposlene. Sledi voditeljstvo z značilnostmi organizacijske kulture tipa hierarhija (vrednost $=32,98$ ), tipa adhokracija $($ vrednost $=16,72)$ in tipa trg $($ vrednost $=11,62)$.

Pri tem vidiku organizacijske kulture smo med obstoječo in želeno organizacijsko kulturo ugotovili statistično značilne razlike pri naslednjih tipih organizacijskih kultur:

- organizacijska kultura tipa klan: anketirane osebe si v prihodnje želijo večje podpore vodstva, mentorskega odnosa in skrbi za zaposlene $(\mathrm{t}=-7,34$; Sig. = 0,000);

- organizacijska kultura tipa trg: anketirane osebe si v prihodnosti želijo manj usmerjenosti $v$ izid in agresivnega voditeljstva $(t=$ 7,98; Sig. = o,o०o).

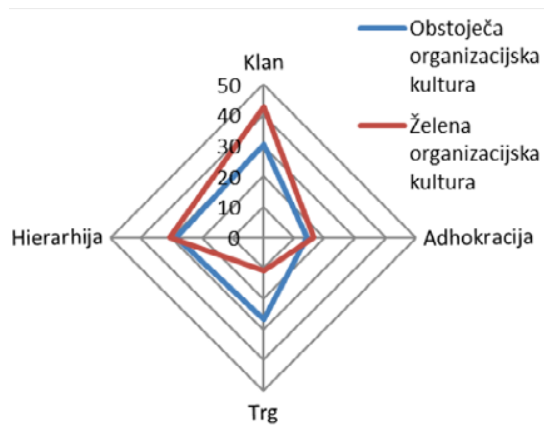

Slika 7.6: Grafični prikaz profila zaznane in želene organizacijske kulture pri ravnanju z zaposlenimi

Značilnosti načina ravnanja s sodelavci smo ugotavljali na podlagi odgovorov tretjega sklopa vprašanj iz vprašalnika. Izidi tretjega sklopa vprašanj, ki se nanašajo na zaznano in želeno organizacijsko kulturo pri 
načinu ravnanja s sodelavci, so prikazani na sliki 7.6. Po mnenju anketiranih oseb v AJPES prevladuje način ravnanja s sodelavci z značilnostmi organizacijske kulture tipa klan (vrednost $=29,80$ ), za katerega so značilni timsko delo, iskanje soglasja in sodelovanje. Sledijo značilnosti organizacijske kulture tipa hierarhija (vrednost $=28,88$ ), tipa trg (vrednost $=$ $27,19)$ in tipa adhokracija (vrednost $=13,92)$.

Anketirane osebe si v prihodnje želijo ravnanja s sodelavci, ki bi v še večji meri kazalo značilnosti organizacijske kulture tipa klan (vrednost $=42,60$ ). Sledi želena organizacijska kultura tipa hierahija (vrednost $=$ $30,4 \mathrm{I})$, tipa adhokracija $($ vrednost $=16,38)$ in tipa trg $($ vrednost $=10,6 \mathrm{I})$.

Pri tem vidiku organizacijske kulture smo med obstoječo in želeno organizacijsko kulturo ugotovili statistično značilne razlike pri naslednjih tipih organizacijskih kultur:

- organizacijska kultura tipa klan: anketirane osebe si v prihodnje želijo še več timskega dela, iskanja soglasja in sodelovanja $(t=$ $-6,84$; Sig. = o,o0o);

- organizacijska kultura tipa trg: anketirane osebe si v prihodnosti želijo manj tekmovalnosti, visokih zahtev in dosežkov $(t=7,29$; Sig. $=0,000)$.

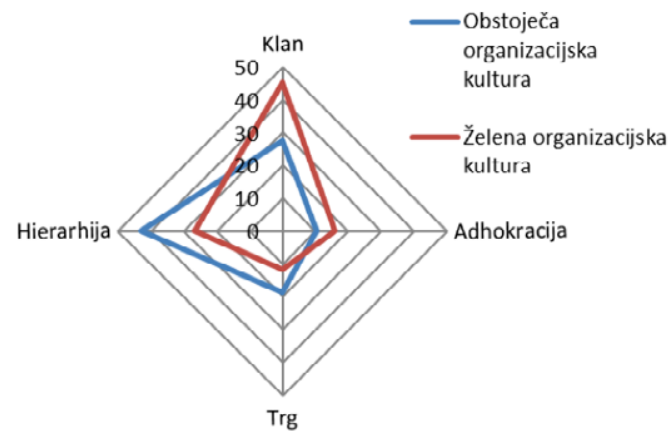

Slika 7.7: Grafični prikaz profila zaznane in želene organizacijske kulture pri vezeh med zaposlenimi

Značilnosti vezi med zaposlenimi smo ugotavljali na podlagi odgovorov četrtega sklopa vprašanj iz vprašalnika. Izidi četrtega sklopa vprašanj, ki se nanašajo na zaznano in želeno organizacijsko kulturo pri vezeh med zaposlenimi v organizaciji, so prikazani na sliki 7.7. Po mnenju anketiranih oseb v AJPES prevladujejo vezi med zaposlenimi z značilnostmi organizacijske kulture tipa hierarhija (vrednost $=43,69$ ), kar pomeni, da so 
tisto, kar povezuje zaposlene, formalna pravila in usmeritve. Sledijo povezovalni dejavniki, ki kažejo značilnosti organizacijske kulture tipa klan (vrednost $=26,82)$, tipa $\operatorname{trg}($ vrednost $=18,94)$ in tipa adhokracija (vrednost $=10,30)$.

Anketirane osebe si v prihodnje želijo vezi med sodelavci, ki bi v največji meri kazale značilnosti organizacijske kulture tipa klan (vrednost = 45,15), kjer sta najpomembnejši povezovalni dejavnik zvestoba in medsebojno zaupanje. Sledi želena organizacijska kultura tipa hierahija (vrednost $=26,57)$, tipa adhokracija $($ vrednost $=16,01)$ in tipa $\operatorname{trg}($ vrednost $=$ II,72).

Pri tem vidiku organizacijske kulture smo med obstoječo in želeno organizacijsko kulturo ugotovili statistično značilne razlike pri vseh štirih tipih organizacijskih kultur:

- organizacijska kultura tipa klan: anketirane osebe si v prihodnje želijo večji poudarek na zvestobi in medsebojnem zaupanju $(\mathrm{t}=$ $-7,78$; Sig. = o,ooo);

- organizacijska kultura tipa adhokracija: anketirane osebe si v prihodnje želijo več zavezanosti inovacijam in razvoju, za kar so pripravljene prevzeti več tveganja $(t=-4,67$; Sig. $=0,000)$;

- organizacijska kultura tipa trg: anketirane osebe si v prihodnosti želijo manj poudarka na doseganju smotrov, ciljev in dosežkih ( $t$ $=4,59$; Sig. = 0,000);

- organizacijska kultura tipa hierarhija: anketirane osebe si v prihodnje želijo manj formalnih pravil in usmeritev $(t=7,60$; Sig. $=0,000)$.

Značilnosti strateških poudarkov smo ugotavljali na podlagi odgovorov petega sklopa vprašanj iz vprašalnika. Izidi petega sklopa vprašanj, ki se nanašajo na zaznano in želeno organizacijsko kulturo pri strateških poudarkih v organizaciji, so prikazani na sliki 7.8. Po mnenju anketiranih oseb v AJPES prevladujejo strateški poudarki z značilnostmi organizacijske kulture tipa hierarhija (vrednost $=32,37$ ), kar pomeni, da se poudarjajo stabilnost in trajnost delovanja, učinkovitost, nadzor in delovanje brez motenj. Sledijo strateški poudarki, ki kažejo značilnosti organizacijske kulture tipa trg (vrednost $=28,59)$, tipa adhokracija (vrednost $=19,95$ ) in tipa klan (vrednost $=18,89$ ).

Anketirane osebe si v prihodnje želijo strateških poudarkov, ki bi v največji meri kazali značilnosti organizacijske kulture tipa klan (vrednost $=34,75)$, kjer se poudarja razvoj zaposlenih, visoko zaupanje, odkritost in 
sodelovanje. Sledijo želena organizacijska kultura tipa hierahija (vrednost $=25)$, tipa adhokracija $($ vrednost $=21,06)$ in tipa trg $($ vrednost $=19,44)$.

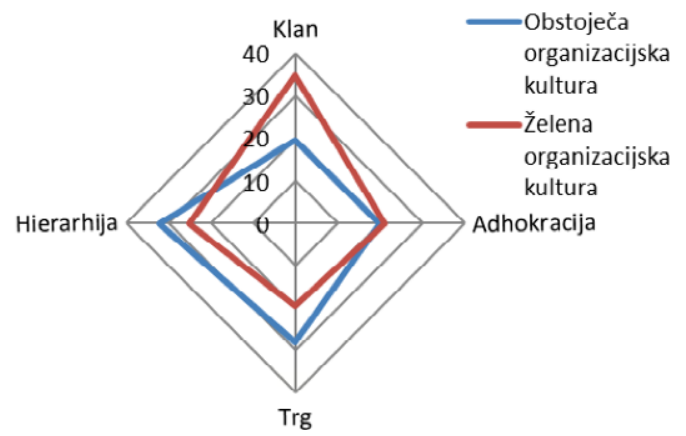

Slika 7.8: Grafični prikaz profila zaznane in želene organizacijske kulture pri strateških poudarkih

Pri tem vidiku organizacijske kulture smo med obstoječo in želeno organizacijsko kulturo ugotovili statistično značilne razlike pri naslednjih tipih organizacijskih kultur:

- organizacijska kultura tipa klan: anketirane osebe si v prihodnje želijo večji poudarek na razvoju zaposlenih in ustvarjanju razmer zaupanja, odkritosti in sodelovanja $(\mathrm{t}=-7,89$; Sig. $=0,000)$;

- organizacijska kultura tipa trg: anketirane osebe si v prihodnosti želijo manj strateških poudarkov, vezanih na konkurenčnost in doseganje smotrov ter ciljev $(t=4,97$; Sig. $=0,000)$;

- organizacijska kultura tipa hierarhija: anketirane osebe si v prihodnje želijo manjši poudarek na strateških usmeritvah, ki se nanašajo na stabilnost, učinkovitost, nadzor in nemoteno delovanje $(t=3,53$; Sig. $=0,00 \mathrm{I})$.

Značilnosti sodil uspešnosti smo ugotavljali na podlagi odgovorov šestega sklopa vprašanj. Izidi šestega sklopa vprašanj, ki se nanašajo na zaznano in želeno organizacijsko kulturo pri sodilih za uspešnost, so prikazani na sliki 7.9. Po mnenju anketiranih oseb v AJPES prevladujejo sodila za uspešnost $\mathrm{z}$ značilnostmi organizacijske kulture tipa hierarhija (vrednost $=42,98)$, kar pomeni, da organizacija opredeljuje svojo uspešnost na osnovi učinkovitosti. Sledijo sodila za uspešnost, ki kažejo značilnosti organizacijske kulture tipa klan (vrednost $=21,92$ ), tipa adhokracija $($ vrednost $=18,48)$ in tipa $\operatorname{trg}($ vrednost $=16,55)$. 
Anketirane osebe si v prihodnje želijo sodil za uspešnost, ki bi v največji meri kazala značilnosti organizacijske kulture tipa klan (vrednost $=38,64$ ), kjer organizacija opredeljuje svojo uspešnost na osnovi razvoja zaposlenih, timskega dela, predanosti zaposlenih in skrbi za ljudi. Sledijo želena organizacijska kultura tipa hierahija (vrednost $=26,2 \mathrm{I})$, tipa adhokracija $($ vrednost $=20,6 \mathrm{I})$ in tipa $\operatorname{trg}($ vrednost $=14,44)$.

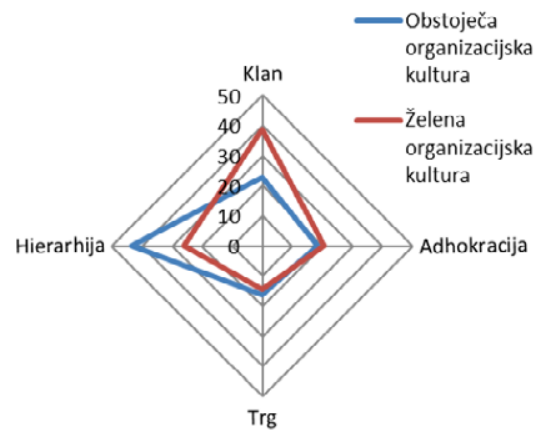

Slika 7.9: Grafični prikaz profila zaznane in želene organizacijske kulture pri sodilih uspešnosti

Pri tem vidiku organizacijske kulture smo med obstoječo in želeno organizacijsko kulturo ugotovili statistično značilne razlike pri naslednjih tipih organizacijskih kultur:

- organizacijska kultura tipa klan: anketirane osebe si v prihodnje želijo uspešnosti organizacije, ki bi temeljila na razvoju zaposlenih, timskem delu, predanosti zaposlenih in skrbi za ljudi $(t=$ $-8,73$; Sig. = o,०००);

- organizacijska kultura tipa hierarhija: anketirane osebe si želijo, $\mathrm{da}$ bi se $\mathrm{v}$ prihodnje uspešnost organizacije manj merila $\mathrm{z}$ učinkovitostjo, $s$ sistematično načrtovanim delom in porabo sredstev $(\mathrm{t}=6,74$; Sig. $=0,000)$.

\section{Analiza glede na vrsto zaposlitve in lokacijo dela}

Analiza je pokazala, da je organizacijska kultura v osmih organizacijskih enotah enaka, in sicer tipa hierarhije, v petih pa drugačna od te. $\mathrm{V}$ izpostavah Koper, Kranj in Velenje anketirani zaposleni zaznavajo organizacijsko kulturo tipa klan, v izpostavah Celje in Nova Gorica pa tipa trg. $V$ vseh petih organizacijskih enotah sledi tip organizacijske kulture hierarhija. Po drugi strani nam ANOVA pokaže, da ni značilnih razlik 
$\mathrm{v}$ dojemanju organizacijske kulture med organizacijskimi enotami (vse vrednosti Sig. nad o,05). Vzrok za tak rezultat je tudi majhno število odgovorov po posameznih organizacijskih enotah.

Iz preglednice 7.4 je razvidno, da je anketirani vodstveni kader manj močno zaznaval organizacijsko kulturo tipa klan, adhokracija in trg v primerjavi z ostalimi zaposleni, medtem ko je organizacijsko kulturo tipa hierarhija zaznaval močneje od ostalih zaposlenih.

Preglednica 7.4: Zaznavanje organizacijske kulture glede na vrsto zaposlitve

\begin{tabular}{|c|c|c|c|c|}
\hline & ZAPOSLITEV & $\mathbf{N}$ & Vrednost & Standardni odklon \\
\hline \multirow{2}{*}{ relativna ocena kulture klan } & vodstveni kader & 17 & 21,13 & 7,31 \\
\hline & nevodstveni kader & 83 & 25,38 & 16,13 \\
\hline \multirow{2}{*}{$\begin{array}{l}\text { relativna ocena kulture ad- } \\
\text { hokracija }\end{array}$} & vodstveni kader & 17 & 13,97 & 6,08 \\
\hline & nevodstveni kader & 83 & 15,70 & 8,02 \\
\hline \multirow{2}{*}{ relativna ocena kulture trg } & vodstveni kader & 17 & 21,94 & II, $8 \circ$ \\
\hline & nevodstveni kader & 83 & $23,7 \mathrm{I}$ & II, 86 \\
\hline \multirow{2}{*}{$\begin{array}{l}\text { relativna ocena kulture hi- } \\
\text { erarhija }\end{array}$} & vodstveni kader & 17 & 42,84 & 13,38 \\
\hline & nevodstveni kader & 83 & 35,06 & 12,10 \\
\hline
\end{tabular}

Glede na t-test je dojemanje organizacijske kulture vodij statistično značilno drugačno od dojemanja ostalih zaposlenih le glede organizacijske kulture hierarhija $($ Sig. $=0,05)$. Pri ostalih tipih kultur pa razlike niso statistično značilne.

\section{Odpor do sprememb}

Preglednica 7.5: Zaznavanje odpora do sprememb

\begin{tabular}{|c|c|c|c|c|}
\hline & & Frekvenca & $\%$ & $\%$ \\
\hline \multirow{6}{*}{ Veljavno } & ne čutim & 27 & 26,7 & 32,9 \\
\hline & neznatno čutim & 32 & 31,7 & 39,0 \\
\hline & čutim & 17 & 16,8 & 20,7 \\
\hline & čutim močneje & 4 & 4,0 & 4,9 \\
\hline & izredno čutim & 2 & 2,0 & 2,4 \\
\hline & skupno & 82 & $8 \mathrm{I}, 2$ & 100,0 \\
\hline Brez podatka & 9 & 19 & $\mathrm{I} 8,8$ & \\
\hline Skupaj & & $\mathrm{IOI}$ & 100,0 & \\
\hline
\end{tabular}


Iz preglednice 7.5 je razvidno, da skoraj petina vprašanih ni odgovorila na vprašanje, v kakšni meri čutijo odpor do sprememb. Razlog gre iskati v občutljivosti vprašanja. Zaradi kočljivega vprašanja menimo, da ni nujno, da so odgovori pokazatelj dejanskega stanja v organizaciji. Na to nas napeljuje dejstvo, da so praktično vsi anketiranci kljub temu odgovarjali na naslednje vprašanje o razlogih za odpor do sprememb (94\% anketiranih je dalo veljavne odgovore).

Glede na preglednico 7.5 je približno tretjina tistih, ki so odgovorili na vprašanje o zaznavanju odpora do sprememb, odgovorila, da ne čuti odpora do sprememb, približno dve tretjini pa ga čuti (39\% neznatno; $20,7 \%$ čuti; $4,9 \%$ čuti močneje in 2,4 \% izredno čuti odpor do sprememb). Vprašanje, ki se je nanašalo na vzroke za odpor do sprememb, je bilo kombiniranega tipa. Ponujenih je bilo namreč pet odgovorov, kjer so anketiranci z od I (sploh ne drži) do 5 (v celoti drži) označili svoje strinjanje z odgovori ter možnost drugega odgovora. Povprečja smo preverili s t-testom za odvisne vzorce. Med vzroki za odpor do sprememb po mnenju anketiranih so v enaki meri prisotne slaba komunikacija, slaba vključenost zaposlenih $\mathrm{v}$ proces sprememb in slaba informiranost o spremembah, $\mathrm{v}$ nekoliko manjši meri pa nepripravljenost za dodatni angažma ter slaba seznanjenost z vizijo, s smotri in cilji AJPES. Možnosti odgovora drugo so se poslužili le štirje vprašani (4\%). Dva od njih sta opozorila na preveliko obremenjenost zaposlenih kot razlog za odpor do sprememb, ostali navedeni razlogi pa so: nemotiviranost, zastarela in nepravična plačna politika, neustrezna sistematizacija delovnih mest, premalo ovrednoten strokovni kader ter preveč kadra na vodstvenih delovnih mestih, pričakovanje boljših rezultatov $\mathrm{z}$ manj zaposlenimi, postavljanje ciljev brez nagrad in brez kazni za njihovo nedoseganje, visoka povprečna starost zaposlenih v določenih službah, nerazumevanje potreb/želja/motivov vsakega zaposlenega.

Ugotovili smo tudi različne vzroke odpora do sprememb v različnih organizacijskih enotah. Pri interpretaciji je treba tudi upoštevati, da je v šestih organizacijskih enotah odgovorilo na to vprašanje po manj kot pet ljudi, v izpostavi Nova Gorica pa nihče. Ugotavljamo, da v izpostavah Kranj, Murska Sobota, Novo mesto in Trbovlje polovica respondentov ne čuti odpora do sprememb, medtem ko ga v različnih jakostih v izpostavi Postojna čutijo vsi respondenti, v izpostavah Ljubljana in Krško $80 \%$ respondentov, v izpostavah Koper in Celje $75 \%$, na centrali 70,5 \%, v izpostavi Velenje $66 \%$ in v izpostavi Maribor $53 \%$ respondentov. Izkazalo se je tudi, da obstajajo razlike pri občutenju odpora do sprememb glede na položaj v službi. Vodstvo ga čuti v $75 \%$, ostali pa v $65,5 \%$. Vodstvo pri 
tem v največjem deležu $(62,5 \%)$ čuti neznaten odpor, medtem ko ga ostali neznatno čutijo le v tretjini primerov, v 22,7 \% pa so navedli, da ga čutijo.

\section{Razlaga rezultatov in preverjanje hipotez}

Rezultati analize kažejo, da je prevladujoči tip organizacijske kulture $\mathrm{v}$ AJPES organizacijska kultura tipa hierarhije ter da bi si zaposleni v bodoče želeli prevladujoče organizacijske kulture tipa klan v vseh njenih vidikih oziroma vsebinskih področjih: $v$ temeljnih značilnostih delovnega okolja, voditeljstvu v organizaciji, načinu ravnanja s sodelavci, vezeh $\mathrm{v}$ organizaciji, strateških poudarkih ter sodilih za uspešnost. Želijo si manj organizacijske kulture tipa hierarhija in trg ter več adhokracije. Ugotavljamo tudi, da zaposleni organizacijsko kulturo dojemajo v vseh organizacijskih enotah enako ter da so statistične razlike v dojemanju organizacijske kulture med vodstvenim kadrom in ostalimi zaposlenimi le glede organizacijske kulture tipa hierarhija. Izidi raziskave kažejo tudi prisotnost odpora do sprememb.

Na podlagi teoretičnih izhodišč, namena in ciljev smo oblikovali štiri hipoteze. Vsako hipotezo smo preverili z ustrezno metodo statistične analize, pri čemer smo $\mathrm{v}$ dveh primerih $\mathrm{v}$ ničelni hipotezi predpostavili enakost, $\mathrm{v}$ alternativni pa razlike ali vplive, izhajajoče iz raziskovalne hipoteze. Na podlagi izidov analiz smo sprejeli odločitev o veljavnosti postavljenih hipotez.

\section{Hipoteza I}

Prva hipoteza (HI), ki smo jo postavili, se je glasila: Prevladujoči tip organizacijske kulture je kultura hierarhije.

Iz rezultatov osnovne analize je mogoče ugotoviti, da je prevladujoči tip organizacijske kulture v AJPES organizacijska kultura tipa hierarhija (vrednost $=36,86$ ), sledijo organizacijska kultura tipa klan ali skupin $($ vrednost $=23,92)$, tipa trg $($ vrednost $=23,78)$ in tipa adhokracija (vred-

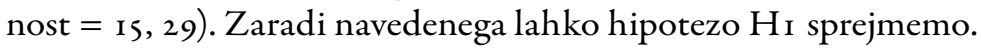

\section{Hipoteza 2}

Druga hipoteza $\left(\mathrm{H}_{2}\right)$, ki smo si jo v nalogi postavili, je bila: Organizacijska kultura je enaka v vseh organizacijskih enotah.

- Ho: Vrednost prevladujoče organizacijske kulture je v vseh organizacijskih enotah enaka.

- Hı: Vrednost prevladujoče organizacijske kulture se razlikuje med organizacijskimi enotami. 
Iz analize je s primerjavo vrednosti ocen posameznih tipov kultur razvidno, da je organizacijska kultura $v$ osmih organizacijskih enotah enaka, in sicer tipa hierarhija, v petih pa drugačna od te. Po drugi strani pa nam ANOVA pokaže, da ni značilnih razlik v dojemanju organizacijske kulture med organizacijskimi enotami (vse vrednosti Sig. nad 0,05). Vzrok za take rezultate je tudi majhno število odgovorov po posameznih organizacijskih enotah. Iz navedenega sledi, da ne moremo zavrniti ničelne hipoteze, kar pomeni, da se $\mathrm{H}_{2}$ potrdi.

\section{Hipoteza 3}

Tretja hipoteza $\left(\mathrm{H}_{3}\right)$, ki smo jo v nalogi postavili, je bila: Dojemanje organizacijske kulture vodij je statistično značilno drugačno od dojemanja ostalih zaposlenih.

- Ho: Prevladujoča organizacijska kultura je enaka v obeh skupinah.

- $\mathrm{H}_{\mathrm{I}}$ : Prevladujoča organizacijska kultura vodij in ostalih zaposlenih je različna.

Za preverjanje ničelne hipoteze smo opravili t-test za neodvisna vzorca (Independent Samples T-Test). Pred tem smo upoštevali rezultate za preizkus enakosti varianc in šele nato rezultate za preizkus enakosti povprečij. Na osnovi Levenovega testa za enakost varianc smo ugotovili, da sta varianci odvisne spremenljivke na vzorcu enaki za vse tipe organizacijskih kultur, z izjemo organizacijske kulture tipa klan, in nato upoštevali pripadajoči izid t-testa. Značilne razlike med skupinama smo ugotovili le v primeru relativne ocene organizacijske kulture tipa hierarhija (sig. = 0,039). Pri ostalih tipih kultur razlik med skupinama nismo zaznali: klan (sig. = 0,096), adhokracija $($ sig. $=0,404)$ in trg $($ sig. $=0,575)$. Navedeno pomeni, da je dojemanje organizacijske kulture vodij statistično značilno drugačno od dojemanja ostalih zaposlenih le glede organizacijske kulture tipa hierarhija, tako da hipotezo $\mathrm{H}_{3}$ lahko sprejmemo.

\section{Hipoteza 4}

Četrta hipoteza ( $\left.\mathrm{H}_{4}\right)$, ki smo jo v nalogi postavili, je bila: Zaposleni ne čutijo odpora do sprememb.

Iz rezultatov osnovne analize izhaja, da je le 32,9 \% tistih, ki so odgovorili na vprašanje o zaznavanju odpora do sprememb, odgovorilo, da ne čutijo odpora do sprememb, $67 \%$ pa ga čuti (39\% neznatno; 20,7 \% čuti; $4,9 \%$ čuti močneje in $2,4 \%$ izredno čuti odpor do sprememb). Ker večina zaposlenih izraža, da čutijo odpor do sprememb, $\mathrm{H}_{4}$ ne potrdimo. 


\section{Predlogi za izboljšanje}

Iz raziskave izhaja, da ima AJPES natančno opredeljeno politiko organizacije - vizijo, poslanstvo, smotre in cilje ter strategijo v skladu z interesi in vrednotami pomembnih udeležencev in $\mathrm{v}$ skladu $\mathrm{z}$ nacionalno politiko, s strategijo razvoja javne uprave in z nacionalnimi predpisi, kar ambiciozno tudi uresničuje. Pestrost vrednot, ki jih goji, je tudi posledica spoznanja, da se AJPES, poleg nudenja javnih storitev, uveljavlja tudi na trgu. Posledično se to zrcali v prisotnosti različnih tipov organizacijskih kultur, kjer pa vseeno prednjači tip hierarhije. Izidi raziskave kažejo na to, da bi si anketiranci v bodoče želeli prevladujoče organizacijske kulture tipa klan $\mathrm{v}$ vseh njenih vidikih oziroma na vsebinskih področjih: $\mathrm{v}$ temeljnih značilnostih delovnega okolja, voditeljstvu v organizaciji, načinu ravnanja s sodelavci, vezeh $\mathrm{v}$ organizaciji, strateških poudarkih ter sodilih za uspešnost. Usklajenost vseh atributov organizacijske kulture dokazano vodi k večji uspešnosti organizacije. Želijo si manj organizacijske kulture tipa hierarhija in trg ter več adhokracije.

Glede na izide raziskave z namenom približanja obstoječe organizacijske kulture želeni organizacijski kulturi predlagamo spremembe po posameznih atributih organizacijske kulture, in sicer:

- pri temeljnih značilnostih delovnega okolja predlagamo zagotovitev delovnega okolja, ki bi omogočalo več medsebojnega sodelovanja in povezanosti, več inovativnosti, dinamičnosti, ustvarjalnosti in podjetnosti ter bistveno manj nadzora, strukturiranosti in manj pravil ter postopkov pri opravljanju svojega dela, manj tekmovalnosti in usmerjenosti v izid;

- pri voditeljstvu v organizaciji predlagamo tako vodenje, ki bi bilo usmerjeno v dajanje zgleda, mentorski odnos, svetovanje zaposlenim pri delu, podpiranje in skrb za zaposlene ter manj $\mathrm{v}$ agresivno vodenje, usmerjeno $v$ izide;

- pri načinu ravnanja s sodelavci, kljub temu, da anketiranci ocenjujejo, da način ravnanja že odraža organizacijsko kulturo tipa klan, predlagamo vztrajanje pri dejavnostih, ki bi omogočale še več timskega dela in sodelovanja, pri tem pa je potrebno paziti, da se ne razvija tekmovalnost in da niso poudarjene visoke zahteve ter dosežki;

- pri vezeh $\mathrm{v}$ organizaciji predlagamo oblikovanje razmer, kjer bi zaposlene povezovali medsebojno zaupanje in zvestoba, zavezanost $\mathrm{k}$ inovacijam in razvoju, ne pa poudarek na dosežkih in do- 
seganje smotrov ter ciljev, zmagovanje kot tudi neformalna pravila in usmeritve;

- pri strateških poudarkih predlagamo večji poudarek na razvoj zaposlenih in ustvarjanje razmer zaupanja, odkritosti in sodelovanja ter manjši poudarek na konkurenčnost in doseganje smotrov ter ciljev in na stabilnost, učinkovitost, nadzor in nemoteno delovanje;

- pri sodilih za uspešnost predlagamo taka merila uspešnosti, ki se nanašajo na razvoj zaposlenih, timsko delo, predanost zaposlenih in skrb za ljudi, manj pa na učinkovitost, sistematično načrtovano delo in manjšo porabo sredstev.

AJPES že sedaj posveča veliko pozornosti zaposlenim, saj so po besedah direktorice ti pomemben most med gospodarstvom in javnim sektorjem, zato bo po njenih besedah organizacija še naprej gojila dober odnos z zaposlenimi, se zavzemala za partnerski odnos z državo ter profesionalen odnos do vseh deležnikov, ki temelji na medsebojnem spoštovanju ter realnih finančnih in zakonskih podlagah. Skrb za razvoj zaposlenih se kaže tudi v izobraževanju, načrtovanju individualnega razvoja v letnih razgovorih, njihovi vključenosti v različne skupine - v letu 2015 je bilo tako izvedenih 13 strokovnih usposabljanj z udeležbo po več kot 20 zaposlenih, zaposleni so vključeni tudi v 26 delujočih projektnih, strokovnih in delovnih skupin za izvajanje strokovnih nalog (»Letno poročilo AJPES za leto $20152016 \ll, 7-9)$. Vse to že sedaj kaže na pravilno naravnanost kadrovske politike. Nenazadnje so anketiranci v raziskavi ocenili, da za način ravnanja s sodelavci že sedaj veljajo značilnosti organizacijske kulture tipa klan. Zaradi navedenega predlagamo vztrajanje pri dobrih praksah pri vodenju kadrovske politike organizacije in njeno dopolnitev s predlaganimi usmeritvami ob konkretizaciji in realizaciji predlogov.

Izidi raziskave kažejo tudi prisotnost odpora do sprememb, saj le 32,9 \% vprašanih ne čuti odpora do sprememb. Med vzroki za odpor do sprememb po mnenju anketiranih so v enaki meri prisotne slaba komunikacija, slaba vključenost zaposlenih v proces sprememb in slaba informiranost o spremembah, v nekoliko manjši meri pa nepripravljenost za dodatni angažma ter slaba seznanjenost $z$ vizijo, s smotri in cilji organizacije. Zaradi navedenega predlagamo zagotavljanje uspešne komunikacije z zaposlenimi z njihovo večjo seznanjenostjo o spremembah in njihovo večjo vključenostjo v proces spreminjanja.

Za spremembo organizacijske kulture predlagamo uporabo šestih korakov, ki jih opisujeta Cameron in Quinn, in sicer doseganje soglasja glede trenutne organizacijske kulture, doseganje soglasja glede želene 
organizacijske kulture, določitev sprememb in tega, kaj je mišljeno s posamezno spremembo, identificiranje pomembnih ponazarjajočih zgodb, razvoj strateškega akcijskega načrta (z ustrezno strategijo komuniciranja) in razvoj izvedbenega načrta (s poudarkom na šestih S-strukturah: simbolih, sistemih, sodelavcih, strategijah, stilih vodenja in sposobnostih vodstva). Namen naštetih korakov je v povečanju vključenosti zaposlenih in $v$ zmanjšanju odpora do sprememb (uspeh sprememb je po avtorjih v veliki meri odvisen od soglasja zaposlenih), poleg tega se tako nazorno predstavi obseg sprememb in določi, česa se ne bo spreminjalo ter aktivnosti, ki bodo pomenile začetek spreminjanja organizacijske kulture. Upoštevajoč Camerona in Quinna predlagamo, da se v organizaciji razvija in zagotovi podporno okolje in pripravljenost na spremembe, za kar priporočajo oblikovanje zavezništva podpornikov, osredotočenost na proces spreminjanja, odgovornost in poročanje o spremembah; zagotovi zadostna informiranost s poudarkom na razlogih za spremembe; zagotovi kriterije in merila uspešnosti pri spreminjanju, da se lahko majhne napredke oziroma želene spremembe izpostavi in nagradi, nezaželeno preteklost brez kritik pokoplje in oblikuje nove simbole, ki bi predstavljali želeno prihodnost (Cameron in Quinn 2006, 69-142).

Stanje v AJPES se sklada tudi s sliko, ki jo razkriva raziskava $\gg$ Leadership Competencies of Successful Change Management «. Njeni zaključki namreč kažejo, da so $\mathrm{v}$ javni upravi prisotni tako tradicionalne vrednote kot vrednote nove kulture kot tudi strah in odpor do sprememb. Rezultati poudarjajo pomen implementacije vrednot nove kulture $\mathrm{v}$ javno upravo in kažejo na to, da je mogoče tradicionalne vrednote nadomestiti z vrednotami nove kulture (Pagon, Banutai in Bizjak 2008, I I-28).

\section{Povzetek ugotovitev raziskave}

Družbeno okolje, $v$ katerem delujejo pridobitne in nepridobitne, javne ali zasebne organizacije, je vse kompleksnejše in turbulentnejše. Izziv za organizacije ni več, ali se spreminjati, temveč, kako se spreminjati, da bi povečale svojo uspešnost. Na nujnost reforme, ki bo pripeljala do sprememb $\mathrm{v}$ ustanovah javne uprave, so opozorili tudi OECD kot ključni motor reformiranja in spreminjanja javne uprave ter drugi, tuji in domači, teoretiki javne uprave, pri čemer $\mathrm{v}$ fokus reforme organizacij $\mathrm{v}$ javni upravi postavljajo organizacijsko kulturo z oblikovanjem ustrezne strategije in managementa sprememb.

Raziskavo smo izvedli na populaciji 233 zaposlenih v izbrani organizaciji javne uprave - v Agenciji Republike Slovenije za javnopravne evidence in storitve (AJPES), z namenom, da bi ugotovili obstoječo in že- 
leno organizacijsko kulturo, raziskali, ali ljudje na vodstvenih položajih organizacijsko kulturo dojemajo različno od ostalih zaposlenih, ter ugotovili, ali v AJPES zaposleni čutijo odpor do sprememb, pri čemer smo si pomagali z uporabo vprašalnika OCAI Camerona in Quinna (2006, 26-28), ki smo mu dodali še dve vprašanji za ugotavljanje odpora do sprememb, izluščeni iz razmišljanja v delih Huerte Melchorja (Huerta Melchor 2008, 16-20) ter dela Pagona, Banutaija in Bizjaka (2008, 201 I).

Rezultati analize kažejo, da je prevladujoči tip organizacijske kulture v AJPES organizacijska kultura tipa hierarhija ter da bi si zaposleni v bodoče želeli prevladujoče organizacijske kulture tipa klan v vseh njenih vidikih oziroma na vsebinskih področjih: $v$ temeljnih značilnostih delovnega okolja, voditeljstvu v organizaciji, načinu ravnanja s sodelavci, vezeh $\mathrm{v}$ organizaciji, strateških poudarkih ter sodilih za uspešnost. Usklajenost vseh atributov organizacijske kulture dokazano vodi $k$ večji uspešnosti organizacije. Želijo si manj organizacijske kulture tipa hierarhija in trg ter več adhokracije. Iz raziskave izhaja, da zaposleni organizacijsko kulturo $\mathrm{v}$ vseh organizacijskih enotah dojemajo enako ter da so statistične razlike v dojemanju organizacijske kulture med vodstvenim kadrom in ostalimi zaposlenimi le, kar zadeva organizacijsko kulturo tipa hierarhija. Izidi raziskave kažejo tudi prisotnost odpora do sprememb. Stanje v AJPES se sklada tudi s sliko, ki jo razkriva raziskava $\gg$ Leadership Competencies of Successful Change Management.« Njeni zaključki namreč kažejo, da so $\mathrm{v}$ javni upravi prisotni tako tradicionalne vrednote in vrednote nove kulture kot tudi strah in odpor do sprememb (Pagon, Banutai in Bizjak 2008, I I-28).

Vse podatke in informacije, pridobljene iz teoretičnega in empiričnega dela raziskave, smo povezali v sklepna spoznanja, ki so nam služila kot osnova za izdelavo predloga za izboljšanje organizacijske kulture $v$ izbrani pravni osebi javnega prava.

\section{Prispevelk knanosti}

$\mathrm{Z}$ izvedbo raziskave organizacijske kulture s pomočjo uveljavljenega in standardiziranega vprašalnika OCAI Camerona in Quinna, ki temelji na enem najpogosteje uporabljenih modelov obravnave vrednot, na modelu konkurenčnih vrednot Camerona in Quinna, v izbrani organizaciji javne uprave smo prispevali $\mathrm{k}$ zapolnitvi raziskovalne vrzeli na tem področju.

Oblikovali smo štiri raziskovalne hipoteze. Vsako hipotezo smo preverili z ustrezno metodo statistične analize in na podlagi izidov analiz sprejeli odločitev o veljavnosti postavljenih hipotez. Dokazali smo, da je 
prevladujoči tip organizacijske kulture $v$ izbrani organizaciji javne uprave hierarhija, s čimer smo potrdili prvo hipotezo. Drugo hipotezo, ki pravi, da je organizacijska kultura enaka v vseh organizacijskih enotah izbrane organizacije, smo ravno tako potrdili. Ugotovili smo tudi, da je v izbrani organizaciji javne uprave dojemanje organizacijske kulture vodij statistično značilno drugačno od dojemanja ostalih zaposlenih le, kar zadeva organizacijsko kulturo tipa hierarhija, zaradi česar smo potrdili tudi tretjo hipotezo. Četrto hipotezo, ki je predpostavljala, da zaposleni v izbrani organizaciji ne čutijo odpora do sprememb, smo ovrgli, saj smo v raziskavi ugotovili nasprotno.

$\mathrm{Na}$ podlagi izidov raziskave smo zasnovali teoretične in praktične smernice za izboljšanje organizacijske kulture v AJPES, s čimer smo dosegli cilj raziskave. Predlogi se nanašajo na potrebne spremembe za dosego želene organizacijske kulture po posameznih vidikih oziroma vsebinskih področjih organizacijske kulture. Predlagali smo tudi vztrajanje pri dobrih praksah pri vodenju kadrovske politike organizacije in njeno dopolnitev s predlaganimi usmeritvami po posameznih vidikih organizacijske kulture ob konkretizaciji in realizaciji predlogov. Za spremembo organizacijske kulture smo predlagali uporabo šestih korakov, ki jih opisujeta Cameron in Quinn ob razvijanju in zagotavljanju podpornega okolja in pripravljenosti na spremembe. Izhajajoč iz izidov raziskave smo za zmanjšanje odpora do sprememb predlagali zagotavljanje uspešne komunikacije $\mathrm{z}$ zaposlenimi $\mathrm{z}$ večjo seznanjenostjo zaposlenih o spremembah in njihovo večjo vključenostjo $\mathrm{v}$ proces spreminjanja.

Z izvedbo raziskave smo tako prišli do novih empiričnih spoznanj, ki bodo koristna tako za teoretike in raziskovalce kot tudi praktike $v$ javnih ustanovah.

\section{Predlogi za nadaljnje raziskave}

Kljub temu, da se upravljanje strukturno spreminja od hierarhičnega upravljanja do omrežij oziroma kot proces od klasičnega pristopa do novega pristopa $v$ javni upravi, čemur sledi tudi upravna kultura, pa žal tega ne moremo $\mathrm{z}$ gotovostjo trditi za kulturo posamezne organizacije $\mathrm{v}$ javni upravi, saj na tem področju v Sloveniji nismo zasledili raziskav. Raziskava, ki smo jo opravili v izbrani organizaciji javne uprave, kaže, da je trenutni tip organizacijske kulture še vedno hierarhija in da si zaposleni želijo organizacijske kulture tipa skupina oziroma klaa. Glede na to, da posamezna organizacija $\mathrm{v}$ javni upravi predstavlja subkulturo upravne kulture, bi si bilo potrebno prizadevati za spremembo posameznih organizacijskih 
kultur in tako povzročiti spremembe tudi od spodaj navzgor - na državno raven oziroma upravno-kulturo.

Zaradi pomanjkanja tovrstnih raziskav $\mathrm{v}$ javni upravi predlagamo, da bi se opravile raziskave $\mathrm{v}$ organizacijah javne uprave na področju organizacijske kulture $\mathrm{z}$ namenom ugotoviti, ali ta podpira druge sestavine politike organizacije in ali je prisoten odpor do sprememb. $Z$ oblikovanjem primerne organizacijske kulture, $s$ strateškim managementom in $\mathrm{z}$ managementom sprememb bodo tudi reforme privedle do želenih sprememb ter tudi pripomogle $\mathrm{k}$ spremembi upravne kulture in organizacijske kulture.

Predlagamo:

- izvedbo raziskav s področja organizacijske kulture in odpora do sprememb, in sicer v organizacijah državne uprave, organizacijah lokalne samouprave in nosilcih javnih pooblastil ter izvajalcih javnih služb in skupno za javno upravo (s čimer bi tudi ugotovili, v kakšni meri so prisotni tradicionalne vrednote, vrednote nove kulture ter strah in odpor do sprememb), na način, da bi bila možna primerjava posamezne organizacije s splošnim profilom;

- periodično izvajanje raziskav zaradi možnosti ugotavljanja približevanja vrednotam novega pristopa oziroma načelom dobrega upravljanja, ki so zapisani $v \gg$ Politiki napredka in kakovosti sodobne javne uprave $\ll$;

- izvedbo raziskav z uporabo enake metode raziskovanja oziroma uporabo vprašalnika OCAI, saj tipe upravljanja in pristope v javni upravi upravno-kulturo razvrščamo na podlagi enakih uveljavljenih miselnih shem, kot to velja za model konkurenčnih vrednot (pa vendar bi bilo tudi to trditev potrebno podkrepiti z več dokazi), s čimer bi omogočili primerljivost na vseh ravneh;

- izvedbo raziskav vpliva organizacijske kulture na izbrane finančne in nefinančne kazalnike uspešnosti organizacije $v$ javni upravi;

- izvedbo raziskav organizacijske kulture z drugimi vprašalniki, kot so npr. Organizational Culture Inventory - OCI (Cooke in Lafferty), Denison Organizational Scale - DOCS (Denison), Organizational Description Questionnaire - ODQ (Bass in Avolio), Time-At-Work Questionnaire (Schriber in Gutek), Person-Organization Fit Scale (Bretz in Hudje), Competing Value Scale (Meyer, Hecht, Gill in Toplonytsky) (po Zakrajšek in Žuntar 2012, 2-17), in primerjavo rezultatov; 
- izvedbo raziskav s področja organizacijske kulture in odpora do sprememb $\mathrm{v}$ organizacijah javne uprave $\mathrm{v}$ tujini ter primerjavo izidov $\mathrm{z}$ izidi domačih organizacij;

- redno izvajanje raziskav s tega področja v izbrani organizaciji javne uprave, $s$ čimer bi bilo možno primerjati rezultate in na ta način ugotoviti napredek oziroma spremembe, ki so posledica ukrepov za uskladitev organizacijske kulture s strategijo, ter zmanjšati odpor do sprememb.

\section{Literatura}

AJPES. 2015. »Zapisnik I3. seje Kolegija AJPES.« Številka: or3-13/2015-2. Interno gradivo, AJPES.

AJPES. 2016a. »Letno poročilo AJPES za leto 2015.《 Številka: 007-15/20162. Interno gradivo, AJPES.

AJPES. 2016b. »Program dela AJPES za leto 2016.« Številka: 070-3/2016-I. Interno gradivo, AJPES.

Bryson, J. M., B. C. Crosby in L. Bloomberg. 2014. »Public Value Governance: Moving beyond Traditonal Public Administration and the New Public Management.« Public Administration Reviw 74 (4): 445-46.

Cameron, K. S., in R. E. Quinn. 2006. Diagnosing and Changing Organizational Culture. San Francisco: Jossey-Bass.

Esterby-Smith, M., R. Thorpe in A. Lowe. 2004. Raziskovanje v managementu. Fakulteta za management Koper Univerze na Primorskem.

Huerta Melchor, O. 2008. »Managing Change in OECD Governments: An Introductionary Framework.« OECD Working Papers on Public Governance, št. I 2. France: OECD Publishing.

Malbašić, I. 2015. »Vpliv uravnoteženih organizacijskih vrednot na poslovanje.« Doktorska disertacija, Univerza v Mariboru.

Pagon, M., E. Banutai in U. Bizjak. 2008. »Leadership Competenies for Succesful Change Management.« Študijsko poročilo, Univerza v Mariboru.

Pagon, M., E. Banutai in U. Bizjak. 20I I. »Organizational Culture in European Public Administration Institutions: New and Traditional Values, Fear, and Resistance to Change.« http://www.academia.edu/78894I5/Organizational_Culture_in_European_Public_Administration_Institutions_ New_and_Traditional_Values_Fear_and_Resistance_to_Change.

Zakrajšek, T., in S. Žuntar. 20I 2. Izbrani vprašalniki za uporabo na področju psibologije dela in organizacije. Organizacijska kultura. Ljubljana: Univerza v Ljubljani, Filozofska fakulteta. 



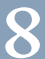 \\ Organizacijska kultura v slovenskih gledališčih
}

\author{
Petra Setničar in Mirko Markič
}

V zadnjem obdobju je zanimanje za organizacijsko kulturo naglo naraslo in posledica je porast raziskav organizacijske kulture $\mathrm{v}$ različnih organizacijah in panogah. V slovenskih gledališčih organizacijska kultura še ni bila preučevana, zato smo se odločili raziskati, kakšen tip organizacijske kulture prevladuje, ali je prevladujoči tip skladen pri večini dimenzij in ali obstajajo razlike v dojemanju organizacijske kulture med posameznimi sektorji. Raziskali smo tudi povezanost tipov kulture in zadovoljstva zaposlenih z delom in delovnimi razmerami.

\section{Populacija in vzorec}

Populacija so zaposleni v slovenskih gledališčih, in sicer na dan 3I. I2. 2014 je bilo skupaj 527 zaposlenih (AJPES b. l.). Vprašalnik smo razposlali po elektronski pošti, nekaterim pa smo ga razdelili osebno. Dosegli smo povprečno odzivnost, tj. $31 \%$. Flere (2000, I28) namreč ugotavlja, da se običajno na ankete odzove $20-40 \%$ ljudi.

Po podatkih Statističnega urada RS (b. 1.) je bilo januarja 2016 v kulturni, razvedrilni in rekreacijski dejavnosti v RS skupaj zaposlenih I 4.28 I oseb, od tega 50,6 \% (7.227) moških in 49,6 \% (7.054) žensk. Pri naših anketirancih pa je razmerje v prid ženskam, saj se je na anketo odzvalo 54,8 \% (9I) žensk in 45,2 \% (75) moških.

Gledališča so razdeljena na tri organizacijske enote, sektorje: umetniškega, tehničnega in splošnega. $\mathrm{Na}$ anketo je odgovorilo 69 zaposlenih iz umetniškega sektorja, kar predstavlja 41,6 \% vseh anketirancev, 55 zapo- 
slenih iz splošnega sektorja, kar je 33,r \% anketirancev, in 42 zaposlenih iz tehničnega sektorja, kar je 25,3\% anketiranih.

Največ anketirancev je bilo iz razreda med 40 in 50 let, odgovorilo jih je $65(39,2 \%)$, sledijo tisti med 50 in 60 let, ki jih je odgovorilo $42(25,3$ $\%), v$ razredu med 30 in 40 let jih je odgovorilo 34 (20,5\%), I2 (7,2\%) jih je odgovorilo v razredu med 20 in 30 let in $13(7,6 \%)$ tistih nad 60 let.

Preglednica 8.r: Demografska struktura anketirancev

\begin{tabular}{lcc} 
& Frekvenca & Delež (\%) \\
\hline ženski & Spol & \\
\hline moški & 91 & 54,8 \\
\hline Skupaj & 75 & 45,2 \\
\hline & 166 & 100,0
\end{tabular}

\begin{tabular}{lcc} 
splošni & 55 & 33,1 \\
\hline tehnični & 42 & 25,3 \\
\hline umetniški & 69 & 41,6 \\
\hline & 166 & 100,0
\end{tabular}

\section{Starost v letih}

\begin{tabular}{lcc} 
nad 20 do 30 let & I2 & 7,2 \\
\hline nad 30 do 40 let & 34 & 20,5 \\
\hline nad 40 do 50 let & 65 & 39,2 \\
\hline nad 50 do 60 let & 42 & 25,3 \\
\hline nad 60 let & 13 & 7,8 \\
\hline Skupaj & 166 & 100,0
\end{tabular}

Izobrazba

\begin{tabular}{lcc} 
I. do IV. stopnja & 27 & 16,3 \\
\hline V.stopnja & 42 & 25,3 \\
\hline VI. stopnja & 15 & 9,0 \\
\hline VII. stopnja aliveč & 82 & 49,4 \\
\hline Skupaj & 166 & 100,0
\end{tabular}


Delovna doba v organizaciji v letih

\begin{tabular}{lcc} 
do io let & 6I & 36,8 \\
\hline nad io do 20 let & 59 & 35,5 \\
\hline nad 20 do 30 let & 29 & 17,5 \\
\hline nad 30 & 17 & 10,2 \\
\hline Skupaj & 166 & 100,0 \\
\hline
\end{tabular}

Skoraj polovico $(49,4 \%)$ odgovorov smo prejeli od anketirancev z najmanj VII. stopnjo izobrazbe, sledijo tisti s V. stopnjo izobrazbe $(25,3 \%)$, nato tisti z najnižjo izobrazbo (I. do IV. stopnja), ki jih je bilo I6,3 \%, VI. stopnjo izobrazbe pa ima $9 \%$ anketirancev. Takšna struktura je posledica dejstva, da je bilo največ anketirancev iz umetniškega sektorja, v katerem je visoka izobrazba pogoj za zaposlitev. Visoko izobrazbo ima tudi veliko zaposlenih iz splošnega sektorja, v tehničnem sektorju pa prevladuje nižja izobrazba.

Glede na delovno dobo, ki so jo anketiranci preživeli v organizaciji, prevladujeta razreda do io let delovne dobe v organizaciji $(36,8 \%)$ in nad Io do 20 let $(35,5 \%)$. Iz razreda nad 20 do 30 let je odgovorilo $17,5 \%$ anketiranih in $10,2 \%$ tistih $\mathrm{z}$ več kot 30 let delovne dobe $\mathrm{v}$ organizaciji.

\section{Opis instrumenta}

$\mathrm{V}$ raziskavi smo uporabili metode, značilne za kvantitativno raziskovanje, kot jih opisujejo Easterby-Smith, Thorpe in Lowe (2005, 163-68). Kot način zbiranja kvantitativnih podatkov je bil uporabljen anketni vprašalnik zaprtega tipa, zasnovan na osnovi strokovne literature in na osnovi vprašalnikov, uporabljenih $\mathrm{v}$ dosedanjih raziskavah, ki ga sestavljajo trije vsebinski sklopi. Prvi sklop se je nanašal na demografska vprašanja (spol, sektor, starost, izobrazba in delovna doba v organizaciji), ki smo jih predstavili s pomočjo deskriptivne statistike.

$\mathrm{V}$ drugem delu vprašalnika smo ugotavljali zadovoljstvo z delom in delovnimi razmerami. Poslužili smo se vprašalnika, ki ga za ugotavljanje zadovoljstva zaposlenih uporabila Kragelj (2010), pri čemer smo uporabili 39 od njengovih 40 vprašanj. Zanesljivost vprašalnika, natančneje njegovo notranjo konsistentnost, smo preverili s Cronbachovim alfa testom. Test je pokazal, da je vrednost Cronbachovega koeficienta alfa 0,9 I 7 , kar pomeni odlično zanesljivost oziroma notranjo konsistentnost vprašalnika. 
Tretji del pa je bil standardiziran vprašalnik OCAI, ki sta ga razvila Cameron in Quinn (2006); z njim smo analizirali prevladujoči tip organizacijske kulture (prav tam, 23) v izbranih gledališčih in ugotovili želeni tip organizacijske kulture (prav tam, 23).

Zanj smo se odločili predvsem zaradi njegove praktičnosti, časovne ustreznosti in veljavnosti. Vprašalnik OCAI nam na osnovi ustreznih merskih karakteristik nudi vpogled $\mathrm{v}$ delovanje organizacije in njene značilne vrednote ter pokaže razkorak med sedanjo in želeno organizacijsko kulturo. Je prosto dostopen in preprost za vrednotenje. Uporabimo ga lahko na vseh nivojih organizacije (Zakrajšek in Žuntar 2012/2013).

Vprašalnik OCAI (Cameron in Quinn 2006, 23-30) je razdeljen na šest sklopov, ki predstavljajo šest dimenzij organizacijske kulture: glavne značilnosti organizacije, stil vodenja, ravnanje z zaposlenimi, lepilo organizacije, strateški poudarki in merilo uspeha.

Vsak sklop (dimenzija) vsebuje štiri trditve, ki opredeljujejo določen tip organizacijske kulture (prav tam, 23-30):

- A - kultura klana,

- B - kultura adhokracije,

- C - kultura trga in

- D - kultura hierarhije.

Anketiranec med te štiri trditve pri vsaki dimenziji razdeli dvakrat po Ioo točk, in sicer (v skladu s priporočili avtorjev) (prav tam, 25) najprej za sedanje stanje, $v$ drugem koraku pa še za želeno stanje.

$\mathrm{Na}$ osnovi seštevka točk posameznih alternativ (posebej za sedanje in posebej za želeno stanje) smo ugotavljali povprečje alternativ, ki je določilo prevladujoči tip organizacijske kulture.

Vprašalnik OCAI temelji na ipsativnem vrednotenju: anketiranci razporedijo točke med posamezne alternative, pri čemer je vsota točk (Ioo) točno določena. To pomeni, da so postavke soodvisne, kar lahko vpliva na rezultat, zato naj bi bili na to pozorni (Zakrajšek in Žuntar 2012/2013).

Teoretično osnovo za standardizirani vprašalnik OCAI (The Organizational Culture Assessment Instrument) predstavlja model konkurenčnih vrednost (CVF - The Competing Values Framework), ki sta ga Cameron in Quinn razvila na osnovi raziskav 39 pomembnih kazalnikov učinkovitosti organizacij (Cameron in Quinn 2006). Posamezne tipe kulture, kot sta jih opredelila avtorja (prav tam), podrobneje opisujemo v poglavju 2.5.2. 
Anketo smo izvedli v začetku leta 2016. Anketni vprašalnik smo po gledališčih razposlali po elektronski pošti, kjer pa je bilo to mogoče, smo ga še osebno razdelili, pri čemer smo sodelavce tudi osebno poprosili, da izpolnijo vprašalnik, in $s$ tem zagotovo dosegli večjo odzivnost, kot bi jo sicer. Anketo je izpolnilo I 66 od 527 zaposlenih.

Anketi smo priložili tudi spremno besedilo, s katerim smo na kratko pojasnili namen raziskave in dali navodila za izpolnjevanje, zagotovili anonimnost in se zahvalili za sodelovanje.

\section{Analiza in interpretacija raziskave}

V prvem delu poglavja predstavljamo rezultate odgovorov po metodologiji OCAI. V nadaljevanju opišemo način analize rezultatov raziskave ter nato analiziramo rezultate in preverjanje hipotez.

\section{Vprašalnik OCAI}

\section{Dimenzija glavne značilnosti organizacije}

V tem sklopu oziroma pri tej dimenziji so zaposleni odgovarjali na vprašanja o glavnih značilnostih organizacije. Pri sedanjem stanju prevladuje organizacijska kultura hierarhije, in sicer za 2,6 točke pred kulturo klana in za 4,6 točke pred kulturo trga; to kaže, da zaposleni kot glavno značilnost organizacije dojemajo strukturiranost in ravnanje po pravilih. Glede na to, da po rezultatih irganizacijski kulturi hierarhije tesno sledi organizacijska kultura klana, zaposleni po drugi strani organizacijo dojemajo kot oseben prostor. $\mathrm{V}$ prihodnosti si zaposleni želijo še mnogo več kulture klana ( 34,5 točke), tj. da bi bila organizacija v prihodnosti še bolj orientirana $\mathrm{k}$ zaposlenim in do njih še prijaznejša. Želijo si tudi več kulture adhokracije, tj. bolj dinamične in podjetniško naravnane organizacije, mnogo manj pa kulture hierarhije. Na osnovi preučene teorije lahko razložimo, da si zaposleni želijo predvsem usmerjenosti kulture navznoter in prevladovanja značilnosti, kot so varnost, sodelovanje in zaupanje, ter manj formalnih pravil. 
A Organizacija je oseben prostor. Je kot razširjena družina. Zaposleni veliko zadev delijo z organizacijo.

C Organizacija je usmerjena k rezultatom. Glavna skrb je opraviti vse naloge. Zaposleni so tekmovalni, stremijo k dosežkom.

$24,7 \quad 24,2$

D Organizacija ima močen sistem kontrole in je strukturirana. Zaposleni se ravnajo po formalnih pravilih.

Slika 8. I nam kaže zelo velik razkorak pri kulturi hierarhije, ki sedaj prevladuje, zaposleni pa bi si je v prihodnje želeli mnogo manj. Manj, kot bi si zaposleni želeli, pa sta prisotni kulturi klana in adhokracije. Vidimo pa, da ni razkoraka pri kulturi trga.
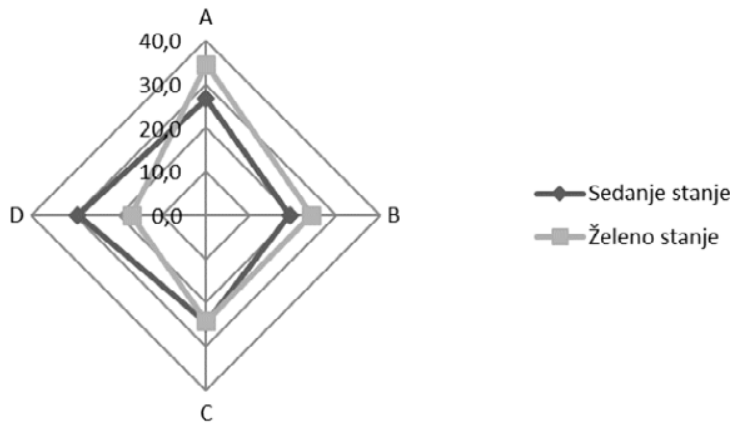

- -Želeno stanje

Slika 8. : Glavne značilnosti organizacije

\section{Dimenzija stil vodenja}

Pri dimenziji stil vodenja zaposleni obstoječo organizacijsko kulturo dojemajo kot kulturo trga $(34,4)$, ki prevladuje pred kulturo hierarhije. To pomeni, da vodenje temelji predvsem na smiselnosti in usmerjenosti $\mathrm{k}$ uresničevanju ciljev ter na koordiniranju, organiziranju in zagotavljanju tekoče učinkovitosti. Najmanj prisotni pri tej dimenziji sta organizacijska kultura adhokracije $(\mathrm{I} 4, \mathrm{I})$ in organizacijska kultura klana $(2 \mathrm{I}, 2)$, ki pa je hkrati tudi najbolj zaželena organizacijska kultura $(33,4)$; to pome- 
ni, da si zaposleni želijo bolj mentorskega vodenja, pomoči in svetovanja. Najmanj zaželena organizacijska kultura za prihodnost je kultura trga, ki se je zaposleni želijo bistveno manj.

Preglednica 8.3: Stil vodenja

\begin{tabular}{|c|c|c|c|}
\hline & 2. STIL VODENJA & Sedanje stanje & Želeno stanje \\
\hline A & $\begin{array}{l}\text { Vodenje organizacije temelji na vzgledu, mentorstvu, svetovan- } \\
\text { ju, skrbi. }\end{array}$ & 21,2 & 33,4 \\
\hline B & $\begin{array}{l}\text { Vodenje organizacije temelji na podjetništvu, inovativnosti in prip- } \\
\text { ravljenosti prevzemanja tveganja. }\end{array}$ & $14, \mathrm{I}$ & 25,2 \\
\hline C & $\begin{array}{l}\text { Vodenje organizacije temelji na smiselnosti. Je agresivno in usmerje- } \\
\text { no k uresničevanju ciljev. }\end{array}$ & 34,4 & 17,5 \\
\hline D & $\begin{array}{l}\text { Vodenje organizacije temelji na koordiniranju, organiziranju in zag- } \\
\text { otavljanju gladko tekoče učinkovitosti. }\end{array}$ & 30,3 & 23,9 \\
\hline & Skupaj & 100 & 100 \\
\hline
\end{tabular}

Iz slike 8.2 razberemo, da obstaja velik razkorak med sedanjo in želeno organizacijsko kulturo pri stilu vodenja, in sicer kar pri treh tipih kulture: kulturi klana in kulturi adhokracije, ki si ju zaposleni v prihodnosti želijo več, ter pri kulturi trga, ki si je zaposleni v prihodnosti želijo bistveno manj.
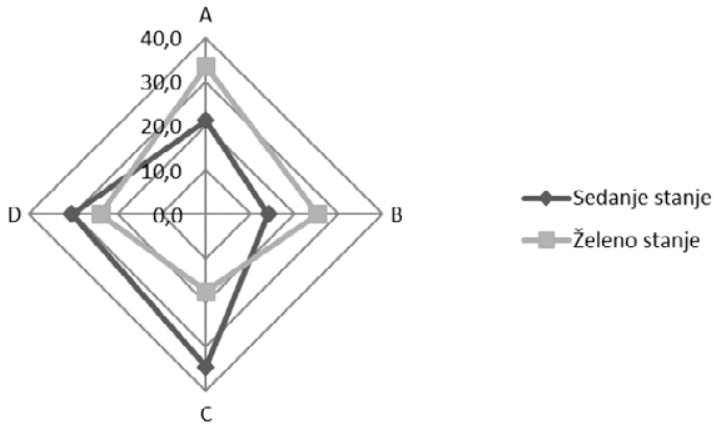

- - Želeno stanje

Slika 8.2: Stil vodenja

\section{Dimenzija raunanje z zaposlenimi}

Zaposleni so odgovorili, da pri dimenziji ravnanje z zaposlenimi prevladuje organizacijska kultura klana, kar pomeni, da način vodenja temelji na timskem delu, iskanju soglasja in vključevanju. Dokaj tesno sledi 
organizacijska kultura hierarhije, kar kaže na to, da v organizaciji skrbijo za zagotavljanje varnosti zaposlitve, udobnost, predvidljivost in stabilnost medsebojnih odnosov. $V$ prihodnosti si zaposleni želijo še več že sedaj prevladujoče organizacijske kulture klana in tudi več organizacijske kulture adhokracije, kar pomeni, da si pri načinu vodenja želijo več individualnega prevzemanja tveganja in inovativnosti. Želijo pa si mnogo manj prisotnosti organizacijske kulture hierarhije.

Preglednica 8.4: Ravnanje z zaposlenimi

\begin{tabular}{|c|c|c|c|}
\hline & 3. RAVNANJEZZAPOSLENIMI & Sedanje stanje & Želeno stanje \\
\hline A & $\begin{array}{l}\text { Način vodenja temelji na timskem delu, iskanju soglasja in vkl- } \\
\text { jučevanju. }\end{array}$ & 30,0 & 35,7 \\
\hline B & $\begin{array}{l}\text { Način vodenja temelji na individualnem prevzemanju tveganja, ino- } \\
\text { vativnosti, svobodi in izvirnosti. }\end{array}$ & 19,9 & 25,0 \\
\hline $\mathrm{C}$ & $\begin{array}{l}\text { Način vodenja temelji na veliki konkurenčnosti, visokih zahtevah } \\
\text { in dosežkih. }\end{array}$ & 22,8 & 20,3 \\
\hline D & $\begin{array}{l}\text { Način vodenja temelji na težnjah po zagotavljanju varnosti zapos- } \\
\text { litve, udobnosti, predvidljivosti ter stabilnosti medsebojnih } \\
\text { odnosov. }\end{array}$ & 27,3 & 19,0 \\
\hline & Skupaj & 100 & 100 \\
\hline
\end{tabular}

Iz slike 8.3 je razvidno, da pri dimenziji ravnanje z zaposlenimi obstaja največji razkorak pri kulturi hierarhije, ki si je zaposleni v prihodnosti želijo mnogo manj. Najmanjši razkorak pa se kaže pri kulturi trga.

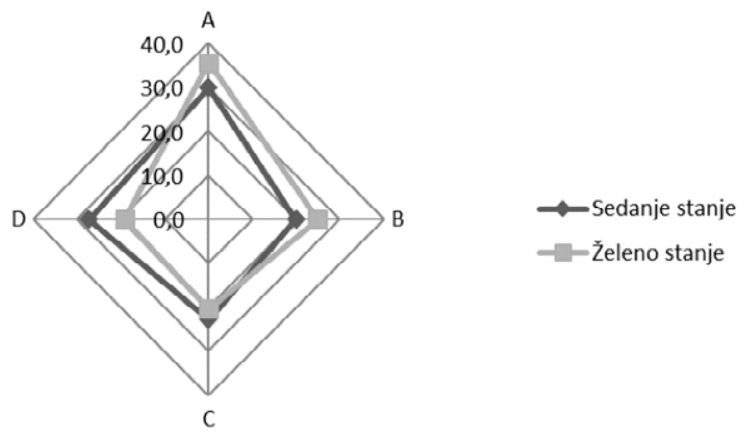

Slika 8.3: Ravnanje z zaposlenimi 


\section{Dimenzija povezovalne sile organizacije}

Pri tej dimenziji prevladuje organizacijska kultura klana $(27,0)$ pred kulturo trga $(24,7)$ in kulturo hierarhije $(24,7)$, najmanj prisotna je organizacijska kultura adhokracije $(22,0)$. To pomeni, da organizacijo povezujeta lojalnost in medsebojno zaupanje. Zaposleni so organizaciji predani. Po drugi strani pa tesno sledi organizacijska kultura trga $(26,3)$, kar pomeni, da organizacijo povezujejo tudi pretekli dosežki ter uresničevanje zastavljenih ciljev in dosežkov. Nekoliko manj so prisotna formalna pravila in zavezanost $\mathrm{k}$ napredku, ki pa bi si je zaposleni želeli več.

Preglednica 8.5: Povezovalne sile organizacije

\begin{tabular}{|c|c|c|c|}
\hline & 4. POVEZOVALNE SILE ORGANIZACIJE & Sedanje stanje & Želeno stanje \\
\hline A & $\begin{array}{l}\text { Organizacijo držita skupaj lojalnost in medsebojno zaupanje. } \\
\text { Zaposleni so organizaciji predani. }\end{array}$ & 27,0 & $38, \mathrm{I}$ \\
\hline B & Organizacijo drži skupaj zavezanost k napredku in inovativnosti. & 22,0 & 28,8 \\
\hline $\mathrm{C}$ & $\begin{array}{l}\text { Organizacijo držijo skupaj pretekli dosežki ter uresničevanje } \\
\text { zastavljenih ciljev in dosežkov. }\end{array}$ & 26,3 & $2 \mathrm{I}, \mathrm{I}$ \\
\hline $\mathrm{D}$ & $\begin{array}{l}\text { Organizacijo povezujejo predvsem formalna pravila in sama politi- } \\
\text { ka organizacije. V organizaciji je pomembno izogibanje nepredvidl- } \\
\text { jivim dogodkom. }\end{array}$ & 24,7 & $\mathrm{I} 2, \mathrm{O}$ \\
\hline & Skupaj & 100 & 100 \\
\hline
\end{tabular}

Iz grafa na sliki 8.4 lahko razberemo, da pri tej dimenziji obstaja velik razkorak med sedanjo in želeno organizacijsko kulturo pri vseh dimenzijah, še posebej pa pri kulturi hierarhije, ki si je zaposleni v prihodnosti želijo bistveno manj. Vidimo, da si zaposleni želijo več kulture klana in kulture adhokracije, kar pomeni več prožnosti in samostojnosti.

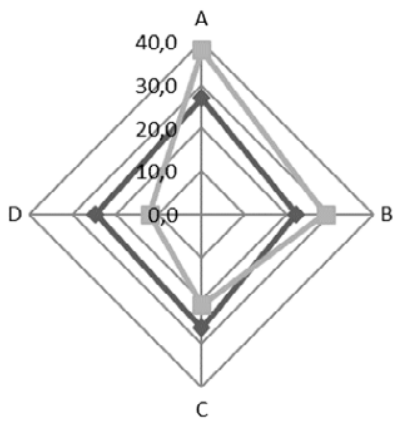




\section{Dimenzija strateški poudarki}

Iz preglednice 8.6 je razvidno, da pri dimenziji strateški poudarki prevladuje organizacijska kultura tipa hierarhija, kar pomeni, da organizacija poudarja stalnost in stabilnost, učinkovitost, kontrolo in tekoče izvajanje dejavnosti. Sledi organizacijska kultura trga - poudarjanje doseganja visoko zastavljenih ciljev in prevlade na trgu. $\mathrm{V}$ prihodnosti si zaposleni pri strateških poudarkih močno želijo organizacijske kulture klana, kar pomeni poudarek na razvoju zaposlenih, zaupanju, odprtosti in sodelovanju.

Preglednica 8.6: Strateški poudarki

A Organizacija poudarja razvoj zaposlenih. V njej prevladujejo visoka stopnja zaupanja, odprtost in sodelovanje.

19,9 40,1

Organizacija poudarja pridobivanje novih virov in iskanje novih

B priložnosti. Preizkušanje novih stvari in iskanje novih priložnosti sta pomembni vrednoti.

C Organizacija poudarja tekmovalnost in dosežke. Najpomembnejša sta doseganje visoko zastavljenih ciljev in prevladovanje na trgu.

D Organizacija poudarja stalnost in stabilnost. Pomembni so učinkovitost, kontrola in tekoče izvajanje dejavnosti. Skupaj

$22,5 \quad 24,2$

24,5

17,7

33, I 18,0

\begin{tabular}{rrr}
\hline Skupaj & 100 & 100
\end{tabular}

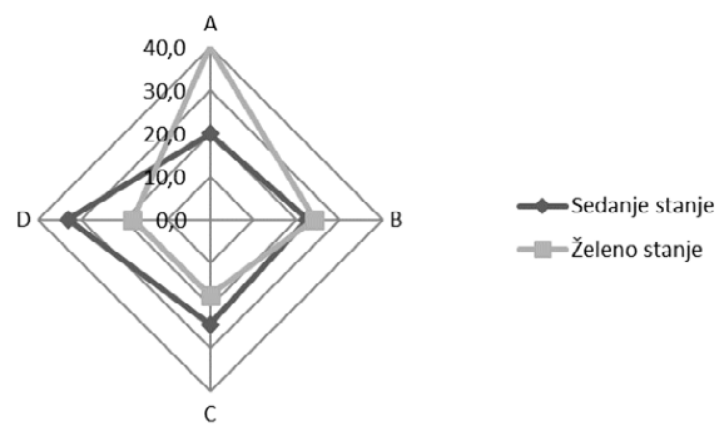

Slika 8.5: Strateški poudarki

Slika 8.5 kaže, da pri strateških poudarkih prevladuje organizacijska kultura tipa hierarhija, ki si je v prihodnosti zaposleni želijo manj. Največji razkorak med sedanjim in želenim stanjem pa se kaže pri kulturi tipa klan (poudarjanje razvoja zaposlenih, zaupanje in sodelovanje), ki si 
je zaposleni močno želijo v prihodnosti. Mnogo manj pa si želijo kulture hierarhije.

\section{Dimenzija merilo uspeha}

Pri tej dimenziji močno prevladuje organizacijska kultura tipa hierarhija $(35,5)$. Sledita organizacijska kultura adhokracije $(24,4)$ in organizacijska kultura trga $(22,2)$. Najmanj prisotna je organizacijska kultura klana $(\mathrm{r} 8,3)$, ki pa si je zaposleni v prihodnosti želijo mnogo več. Merila uspeha naj bodo razvoj zaposlenih, timsko delo, pripadnost zaposlenih in skrb za zaposlene (kultura klana), manj pa učinkovitost in nizki stroški delovanja (kultura hierarhije) ter prevlada na trgu (kultura trga).

Preglednica 8.7: Merilo uspeha

\section{MERILO USPEHA}

\begin{tabular}{|c|c|c|c|}
\hline A & $\begin{array}{l}\text { Organizacija opredeljuje svojo uspešnost na podlagi razvoja zaposlenih, } \\
\text { timskega dela, pripadnosti zaposlenih ter skrbi za zaposlene. }\end{array}$ & 18,3 & 36,8 \\
\hline B & $\begin{array}{l}\text { Organizacija se opredeljuje kot uspešna, kadar ima unikatne in najnove- } \\
\text { jše storitve. Izmišljuje si nove stvari in je vodilna pri razvoju storitev na } \\
\text { svojem področju. }\end{array}$ & $24, \mathrm{I}$ & 26,5 \\
\hline C & $\begin{array}{l}\text { Organizacija opredeljuje svoj uspeh po prevladi na trgu in one- } \\
\text { mogočanju konkurenčnih organizacij. Ključno je prevladovanje na trgu. }\end{array}$ & 22,2 & 15,4 \\
\hline D & $\begin{array}{l}\text { Organizacija opredeljuje svojo uspešnost na podlagi učinkovitosti. } \\
\text { Točnost, tekoč urnik in nizki stroški delovanja so bistvenega pomena. }\end{array}$ & 35,4 & $2 \mathrm{I}, 3$ \\
\hline & Skupaj & 100 & 100 \\
\hline
\end{tabular}

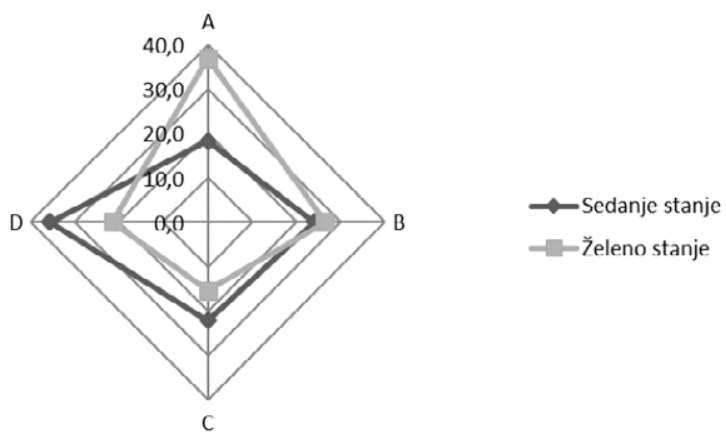

Slika 8.6: Merilo uspeha

Iz slike 8.6 razberemo velik razkorak med sedanjo in želeno prevladujočo organizacijsko kulturo v organizaciji, saj trenutno pri dimenziji 
merilo uspeha močneje prevladuje organizacijska kultura tipa hierarhija, medtem ko si zaposleni v prihodnosti močno želijo kulture tipa klan.

\section{Skupni rezultat - prevladujoči tip sedanje in želene organizacijske kulture}

$\mathrm{V}$ nadaljevanju prikazujemo prevladujoči tip sedanje in želene organizacijske kulture. Izračunali smo ga tako, da smo kumulativno povprečje posamezne dimenzije, ki smo ga dobili s pomočjo predloge za točkovanje vprašalnika OCAI (Cameron in Quinn 2006, 29), delili s številom anketirancev (I66). Rezultate smo preverili še z enim izračunom: sešteli smo povprečja posameznih odgovorov (A, B, C in D) iz vseh dimenzij, posebej za sedanje stanje in posebej za želeno stanje, in vsako dobljeno vsoto delili s šest.

$\mathrm{Na}$ osnovi kumulativne povprečne vrednosti vseh šestih dimenzij sedanjega stanja ugotavljamo, da v slovenskih gledaliških ustanovah prevladuje organizacijska kultura tipa hierarhija (30,1\%), sledi organizacijska kultura trga (25,8\%); obeh si zaposleni v prihodnosti želijo bistveno manj. Močno pa si želijo kulture klana $(36,5 \%)$ in tudi nekoliko več kulture adhokracije (25,6\%).

Preglednica 8.8: Tip organizacijske kulture - sedanje in želeno stanje v organizaciji

\section{Tip organizacijske kulture}

\begin{tabular}{llcc} 
A & Kultura klana & 23,8 & 36,5 \\
\hline B & Kultura adhokracije & 20,3 & 25,6 \\
\hline C & Kultura trga & 25,8 & 19,4 \\
\hline D & Kultura hierarhije & 30,1 & 18,5 \\
\hline & Skupaj & 100 & 100 \\
\hline
\end{tabular}
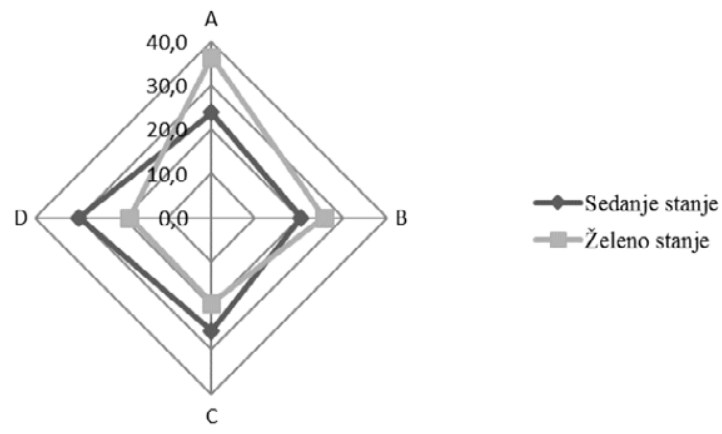

- Želeno stanje 
Slika 8.7 nam prikazuje velik razkorak med sedanjim in želenim stanjem organizacijske kulture pri vseh tipih kulture. Zaposleni si v prihodnosti želijo manj kulture hierarhije in kulture trga. Močno pa si želijo kulture klana in tudi nekoliko več kulture adhokracije. Iz grafa vidimo, da si zaposleni v slovenskih gledališčih želijo bolj integrirane in navznoter usmerjene organizacije.

\section{Opis analize izidov raziskave}

Demografske podatke smo analizirali s pomočjo deskriptivne statistike. Za ugotavljanje sedanjega in želenega tipa organizacijske kulture smo po navodilih metodologije OCAI (Cameron in Quinn 2006, 29), s pomočjo predpisane predloge za točkovanje, iz trditev izračunali povprečne vrednosti po posameznih dimenzijah, ki so nam pokazale sedanji in prevladujoči tip organizacijske kulture. Rezultate smo prikazali v preglednicah in grafično s polarnimi grafi.

Podatki, ki smo jih pridobili na podlagi anketnega vprašalnika OCAI, so spremenljivke, pri katerih se, kot posledica uporabe lestvice $s$ konstantno vsoto (anketiranci pri vsaki dimenziji razdelijo ıoo točk med štiri trditve), pojavlja medsebojna povezanost/soodvisnost med spremenljivkami - pokazateljicami prevladujoče organizacijske kulture. Tako smo uporabili neparametrični preizkus dvojic - Wilcoxonov preizkus predznačenih rangov, in sicer pri prvi hipotezi na ravni vseh dimenzij hkrati (celovita ocena organizacijske kulture), pri drugi hipotezi pa smo postopek ponovili šestkrat - za vsako dimenzijo posebej. Pri tretji hipotezi smo preučevali razlike vseh relevantnih spremenljivk naenkrat med sektorji s pomočjo diskriminantne analize.

Ugotavljali smo tudi povezanost tipov kulture $\mathrm{z}$ dejavniki zadovoljstva $\mathrm{z}$ delom in delovnimi razmerami. $\mathrm{V}$ ta namen smo pri četrti hipotezi najprej s pomočjo faktorske analize izračunali faktorje - dejavnike zadovoljstva. Nato smo za ugotavljanje povezanosti med posameznimi tipi organizacijske kulture (za sedanje in želeno stanje) in dejavniki zadovoljstva $\mathrm{z}$ delom izer delovnimi razmerami izvedli korelacijsko analizo $s$ Pearsonovim korelacijskim koeficientom ( $\mathrm{r}$ ).

Na osnovi izidov raziskave smo oblikovali predloge, ki bi v prihodnosti lahko prinesli pozitivne spremembe organizacijske kulture, saj smo iz odgovorov zaznali, da si zaposleni v prihodnosti želijo spremembe organizacijske kulture. Predvsem si želijo več značilnosti kulture klana in mnogo manj značilnosti kulture hierarhije. 


\section{Interpretacija rezultatov raziskave}

Glede na teoretična izhodišča in rezultate naše raziskave po metodologiji OCAI lahko iz analize kumulativnih povprečij OCAI zaključimo, da v slovenskih gledališčih prevladuje organizacijska kultura tipa hierarhija, kar pomeni, da so slovenska gledališča strukturira in $\mathrm{v}$ njih prevladuje ravnanje po pravilih. Ustanove poudarjajo stalnost in stabilnost, učinkovitost, kontrolo in tekoče izvajanje dejavnosti. Svojo uspešnost opredeljujejo na osnovi učinkovitosti, točnosti, tekočega urnika in nizkih stroškov delovanja, kar pa po našem mnenju niti ni tako presenetljivo, saj gre za javni sektor.

Ugotavljamo tudi, da si zaposleni v slovenskih gledališčih želijo, da bi bila organizacija bolj usmerjena k zaposlenim, do njih prijaznejša, da bi se $\mathrm{v}$ njej počutili kot $\mathrm{v}$ neke vrste razširjeni družini. Vodenje naj temelji na mentorstvu, vzgledu, timskem delu, iskanju soglasja in vključevanju (kultura klana). Želijo si tudi nekoliko bolj podjetniško naravnane organizacije (kultura adhokracije). Organizacijo naj bolj kot formalna pravila in sama politika organizacije (kultura hierarhije) ter pretekli dosežki in uresničevanje zastavljenih ciljev (kultura trga) povezujejo medsebojno zaupanje in predanost zaposlenih (kultura klana) ter inovativnost in zavezanost k napredku (kultura adhokracije).

Zaposleni si želijo, da bi organizacija strateško poudarjala razvoj zaposlenih, zaupanje in sodelovanje (kultura klana), manj pa tekmovalnost in dosežke (kultura trga) ter učinkovitost in tekoče poslovanje (kultura hierarhije). Merilo uspeha naj bodo razvoj zaposlenih, timsko delo, pripadnost zaposlenih in skrb za zaposlene (kultura klana) ter manj učinkovitost in nizki stroški delovanja (kultura hierarhije) in prevlada na trgu (kultura trga).

\section{Preverjanje hipotez}

Hipoteza I: Vizbranih gledališčih prevladuje organizacijska kultura tipa klan.

$S$ pomočjo Wilcoxonovega preizkusa predznačenih rangov smo preverjali statistično pomembno prevlado kulture tipa klan (A).

Najprej smo združili trditve $\mathrm{v}$ štiri vsebinske sklope ustrezno $\mathrm{s}$ štirimi tipi organizacijskih kultur, v skladu z izvirno metodologijo OCAI in s pomočjo programa SPSS izračunali osnovno statistiko (preglednica 8.9) in izračunali povprečne range, pripadajoče posameznemu tipu kulture (preglednica 8.10). 
Preglednica 8.9: Povprečne vrednosti obstoječih tipov kulture

\begin{tabular}{|c|c|c|c|c|c|c|}
\hline \multirow{2}{*}{ Tip kulture } & \multicolumn{2}{|c|}{$\mathbf{N}$} & \multirow{2}{*}{ Povprečje } & \multirow{2}{*}{ Mediana } & \multirow{2}{*}{ Modus } & \multirow{2}{*}{$\begin{array}{l}\text { Stan-dardni } \\
\text { odklon }\end{array}$} \\
\hline & Veljavni & Manjkajoči & & & & \\
\hline A & 166 & $\circ$ & 23,83 & 22,08 & 31,67 & II, 27 \\
\hline B & 166 & $\circ$ & 20,32 & 20,00 & 12,50 & 6,74 \\
\hline C & 166 & $\circ$ & 25,80 & 25,00 & 15,00 & $\mathrm{IO}, \mathrm{I3}$ \\
\hline D & 166 & 0 & 30,05 & 26,67 & $20,83 \mathrm{a}$ & 11,76 \\
\hline
\end{tabular}

Opomba: a - modusov je več; prikazana je najmanjša vrednost.

Vidimo, da je povprečje rangov tipa kulture B (adhokracija) v 9I primerih nižje od povprečij rangov tipa kulture A (klan), 66 jih je višjih in 9 enakih. Pri primerjavi tipa kulture $\mathrm{C}-\mathrm{A}$ vidimo, da je 68 povprečij rangov C (trg) nižjih od povprečij rangov tipa A (klan), 96 je višjih in dva sta enaka kot pri tipu kulture A (klan). Pri primerjavi povprečij rangov tipov kulture D - A vidimo, da je 68 povprečij rangov tipa D (hierarhija) nižjih, 96 je višjih in dva sta enaka povprečjem rangom tipa kulture A (klan).

Preglednica 8.ı: Povprečni rangi posameznih tipov kulture

\begin{tabular}{|c|c|c|c|c|}
\hline \multicolumn{5}{|c|}{ Rangi } \\
\hline & & $\mathbf{N}$ & Povprečje rangov & Vsota rangov \\
\hline \multirow{4}{*}{$B-A$} & Negativni & 9ra & 91,09 & 8289,00 \\
\hline & Pozitivni & $66 b$ & 62,33 & 4114,00 \\
\hline & Izenačeni & $9 \mathrm{c}$ & & \\
\hline & Skupaj & 166 & & \\
\hline \multirow{4}{*}{$\mathrm{C}-\mathrm{A}$} & Negativni & $68 \mathrm{~d}$ & 92,90 & 6317,00 \\
\hline & Pozitivni & $96 \mathrm{e}$ & 75,14 & 7213,00 \\
\hline & Izenačeni & $2 f$ & & \\
\hline & Skupaj & 166 & & \\
\hline \multirow{4}{*}{$\mathrm{D}-\mathrm{A}$} & Negativni & $68 \mathrm{~g}$ & 72,10 & 4903,00 \\
\hline & Pozitivni & $96 \mathrm{~h}$ & 89,86 & 8627,00 \\
\hline & Izenačeni & $2 \mathrm{i}$ & & \\
\hline & Skupaj & 166 & & \\
\hline
\end{tabular}

Preverili smo še statistično pomembno prevlado kulture klan (A). Vse druge tipe kulture (B - adhokracija, $\mathrm{C}-\operatorname{trg}$ in $\mathrm{D}$ - hierarhija) primerja- 
mo $s$ tipom kulture klan (A). Hipotezo smo preverjali z Wilcoxonovim preizkusom predznačenih rangov (Preglednica 8.II). Preizkus izračuna razlike v povprečjih med pari vrednosti. Če je p-vrednost pod o,05, razlike obstajajo. Hipotezo bomo potrdili, če bo p-vrednost manjša od o,o5 pri vseh treh tipih kulture, ki jih primerjamo s tipom kulture A.

Preglednica 8.1 I: Testna statistika - prevladujoči tip kulture

\begin{tabular}{lccc} 
& $\mathrm{B}-\mathrm{A}$ & $\mathrm{C}-\mathrm{A}$ & $\mathrm{D}-\mathrm{A}$ \\
$\mathrm{Z}$ & $-3,662 \mathrm{~b}$ &,$- 736 \mathrm{C}$ & $-3,058 \mathrm{C}$ \\
\hline $\begin{array}{l}\text { Asomptimatična } \\
\text { p-vrednost (2-stranska) }\end{array}$ &, 000 &, 462 &, 002 \\
\hline
\end{tabular}

Vidimo, da je p-vrednost le v dveh primerih manjša od o,o5, zato ne moremo govoriti o prevladi kulture tipa klan (A). Hipotezo I zavrnemo.

Hipoteza 2: Tip organizacijske kulture je skladen pri večini dimenzij.

Hipotezo smo prav tako preverjali z Wilcoxonovim preizkusom predznačenih rangov, pri čemer smo postopek izvedli za vsako dimenzijo posebej. Primerjali smo vse tipe kulture, vsakega posebej, z vsemi dimenzijami, in ugotavljali razlike v povprečjih. Če rezultati omenjenega preizkusa potrdijo statistično pomembno prevlado izbranega tipa organizacijske kulture pri štirih dimenzijah ali več, lahko hipotezo potrdimo.

Za vsako dimenzijo posebej smo izračunali range (preglednice 8.I2, 8.1 4, 8.16, 8.1 8, 8.20 in 8.22) in izvedli testno statistiko (preglednice 8.13, $8.15,8.17,8.19,8.21$ in 8.23$)$. 
Preglednica 8.12: Rangi - glavne značilnosti organizacije

\begin{tabular}{|c|c|c|c|c|}
\hline \multicolumn{5}{|c|}{ Rangi } \\
\hline & & $\mathrm{N}$ & $\begin{array}{c}\text { Povprečje } \\
\text { rangov }\end{array}$ & Vsota rangov \\
\hline \multirow{4}{*}{ A - glavne značilnosti organizacije } & Negativni & 69 & 89,96 & 6207,00 \\
\hline & Pozitivni & 97 & 78,91 & 7654,00 \\
\hline & Izenačeni & $\circ$ & & \\
\hline & Skupaj & 166 & & \\
\hline \multirow{4}{*}{ B - glavne značilnosti organizacije } & Negativni & 33 & 67,45 & 2226,00 \\
\hline & Pozitivni & 129 & 85,09 & 10977,00 \\
\hline & Izenačeni & 4 & & \\
\hline & Skupaj & 166 & & \\
\hline \multirow{4}{*}{$\mathrm{C}$ - glavne značilnosti organizacije } & Negativni & 75 & 83,31 & 6248,00 \\
\hline & Pozitivni & 82 & 75,06 & 6155,00 \\
\hline & Izenačeni & 9 & & \\
\hline & Skupaj & 166 & & \\
\hline \multirow{4}{*}{ D - glavne značilnosti organizacije } & Negativni & 93 & 92,95 & 8644,50 \\
\hline & Pozitivni & 67 & 63,22 & 4235,50 \\
\hline & Izenačeni & 61 & & \\
\hline & Skupaj & 166 & & \\
\hline
\end{tabular}

Iz preglednice 8.13 vidimo, da pri dimenziji Glavne značilnosti organizacije pri tipih kulture $A$ in $C$ razlike v povprečjih ne obstajajo ( $\mathrm{p}$ $>0,05)$. Prevladujeta tipa $\mathrm{B}(\mathrm{p}<0,05, \mathrm{Z}=-7,325)$ in $\mathrm{D}(\mathrm{p}<0,05, \mathrm{Z}=$ $-3,760)$.

Preglednica 8. I3: Testna statistika - glavne značilnosti organizacije

\begin{tabular}{lcccc} 
& $\begin{array}{c}\mathrm{A}- \\
\text { glavne znaćilnosti } \\
\text { organizacije }\end{array}$ & $\begin{array}{c}\mathrm{B}- \\
\text { glavne značilnosti } \\
\text { organizacije }\end{array}$ & $\begin{array}{c}\mathrm{C}- \\
\text { glavne znaćilnosti } \\
\text { organizacije }\end{array}$ & $\begin{array}{c}\mathrm{D}- \\
\text { glavne značilnosti } \\
\text { organizacije }\end{array}$ \\
\hline $\mathrm{Z}$ & $-1,168 \mathrm{~b}$ & $-7,325 \mathrm{~b}$ &,$- 082 \mathrm{C}$ & $-3,760 \mathrm{c}$ \\
\hline $\begin{array}{l}\text { Asomptimatična } \\
\text { P-vrednost } \\
(2-\text { stranska) }\end{array}$ &, 243 &, 000 &, 935 &, 000 \\
\hline
\end{tabular}


Organizacijska kultura in organizacijska klima

Preglednica 8. 4 4: Rangi - stil vodenja

\begin{tabular}{|c|c|c|c|c|}
\hline \multicolumn{5}{|c|}{ Rangi } \\
\hline & & $\mathbf{N}$ & Povprečje rangov & Vsota rangov \\
\hline \multirow{4}{*}{ A - stil vodenja } & Negativni & 97 & 79,02 & 7665,00 \\
\hline & Pozitivni & 69 & 89,80 & 6196,00 \\
\hline & Izenačeni & $\circ$ & & \\
\hline & Skupaj & 166 & & \\
\hline \multirow{4}{*}{ B - stil vodenja } & Negativni & 129 & 85,14 & 10983,00 \\
\hline & Pozitivni & 33 & 67,27 & 2220,00 \\
\hline & Izenačeni & 4 & & \\
\hline & Skupaj & 166 & & \\
\hline \multirow{4}{*}{$\mathrm{C}$-stil vodenja } & Negativni & 82 & 74,18 & 6082,50 \\
\hline & Pozitivni & 74 & 83,29 & 6163,50 \\
\hline & Izenačeni & 10 & & \\
\hline & Skupaj & 166 & & \\
\hline \multirow{4}{*}{ D - stil vodenja } & Negativni & 67 & 63,59 & 4260,50 \\
\hline & Pozitivni & 93 & 92,68 & 8619,50 \\
\hline & Izenačeni & 61 & & \\
\hline & Skupaj & 166 & & \\
\hline
\end{tabular}

Pri dimenziji Stil vodenja pri tipih kulture A in C (preglednica 8.15) razlike v povprečjih ne obstajajo $(\mathrm{p}>0,05)$. Prevladujeta tipa $\mathrm{B}(\mathrm{p}<0,05$, $\mathrm{Z}=-7,335)$ in $\mathrm{D}(\mathrm{p}<0,05, \mathrm{Z}=-3,717)$.

Preglednica 8.1 5: Testna statistika - stil vodenja

\begin{tabular}{lcccc} 
& $\begin{array}{c}\mathrm{A}- \\
\text { stil } \\
\text { vodenja }\end{array}$ & $\begin{array}{c}\mathrm{B}- \\
\text { stil } \\
\text { vodenja }\end{array}$ & $\begin{array}{c}\mathrm{C}- \\
\text { stil } \\
\text { vodenja }\end{array}$ & $\begin{array}{c}\mathrm{D}- \\
\text { stil } \\
\text { vodenja }\end{array}$ \\
\hline $\mathrm{Z}$ & $-\mathrm{-1,185 \textrm {b }}$ & $-7,335 \mathrm{~b}$ &,$- 072 \mathrm{C}$ & $-3,717 \mathrm{c}$ \\
\hline $\begin{array}{l}\text { Asomptimatična } \\
\text { p-vrednost } \\
\text { (2-stranska) }\end{array}$ &, 236 &, 000 &, 943 &, 000 \\
\hline
\end{tabular}


Preglednica 8.1 6: Rangi - ravnanje z zaposlenimi

\begin{tabular}{|c|c|c|c|c|}
\hline \multicolumn{5}{|c|}{ Rangi } \\
\hline & & $\mathbf{N}$ & Povprečje rangov & Vsota rangov \\
\hline \multirow{4}{*}{ A - ravnanje z zaposlenimi } & Negativni & 97 & 78,85 & 7648,50 \\
\hline & Pozitivni & 69 & 90,04 & 6212,50 \\
\hline & Izenačeni & ○ & & \\
\hline & Skupaj & 166 & & \\
\hline \multirow{4}{*}{ B - ravnanje z zaposlenimi } & Negativni & 128 & 84,71 & 10843,50 \\
\hline & Pozitivni & 33 & 66,59 & 2197,50 \\
\hline & Izenačeni & 5 & & \\
\hline & Skupaj & 166 & & \\
\hline \multirow{4}{*}{$\mathrm{C}$ - ravnanje z zaposlenimi } & Negativni & 82 & 75,06 & 6155,00 \\
\hline & Pozitivni & 75 & 83,31 & 6248,00 \\
\hline & Izenačeni & 9 & & \\
\hline & Skupaj & 166 & & \\
\hline \multirow{4}{*}{ D - ravnanje z zaposlenimi } & Negativni & 66 & 63,95 & 4221,00 \\
\hline & Pozitivni & 94 & 92,12 & 8659,00 \\
\hline & Izenačeni & 61 & & \\
\hline & Skupaj & 166 & & \\
\hline
\end{tabular}

Pri dimenziji Ravnanje z zaposlenimi pri tipih kulture A in C (preglednica 8.17) razlike v povprečjih ne obstajajo ( $p>0,05)$. Prevladujeta tipa $\mathrm{B}(\mathrm{p}<0,05, \mathrm{Z}=-7,304)$ in $\mathrm{D}(\mathrm{p}<0,05, \mathrm{Z}=-3,785)$.

Preglednica 8.17: Testna statistika - ravnanje z zaposlenimi

\begin{tabular}{lcccc} 
& $\begin{array}{c}\mathrm{A}- \\
\text { ravnanje zzapos- } \\
\text { lenimi }\end{array}$ & $\begin{array}{c}\mathrm{B}- \\
\text { ravnanje z zapos- } \\
\text { lenimi }\end{array}$ & $\begin{array}{c}\mathrm{C}- \\
\text { ravnanje z } \\
\text { zaposlenimi }\end{array}$ & $\begin{array}{c}\mathrm{D}- \\
\text { ravnanje z } \\
\text { zaposlenimi }\end{array}$ \\
\hline $\mathrm{Z}$ & $-\mathrm{I}, \mathrm{159 \textrm {b }}$ & $-7,304 \mathrm{~b}$ &,$- 082 \mathrm{C}$ & $-3,785 \mathrm{C}$ \\
\hline $\begin{array}{l}\text { Asomptimatična } \\
\begin{array}{l}\text { P-vrednost } \\
(2 \text {-stranska) }\end{array}\end{array}$ &, 247 &, 000 & &, 000 \\
\hline
\end{tabular}


Organizacijska kultura in organizacijska klima

Preglednica 8.18: Rangi - povezovalne sile organizacije

\begin{tabular}{|c|c|c|c|c|}
\hline \multicolumn{5}{|c|}{ Rangi } \\
\hline & & $\mathbf{N}$ & Povprečje rangov & Vsota rangov \\
\hline \multirow{4}{*}{ A - povezovalne sile organizacije } & Negativni & 97 & 78,91 & 7654,00 \\
\hline & Pozitivni & 69 & 89,96 & 6207,00 \\
\hline & Izenačeni & $\circ$ & & \\
\hline & Skupaj & 166 & & \\
\hline \multirow{4}{*}{ B - povezovalne sile organizacije } & Negativni & 129 & 85,09 & 10977,00 \\
\hline & Pozitivni & 33 & 67,45 & 2226,00 \\
\hline & Izenačeni & 4 & & \\
\hline & Skupaj & 166 & & \\
\hline \multirow{4}{*}{$\mathrm{C}$ - povezovalne sile organizacije } & Negativni & 82 & 75,06 & 6155,00 \\
\hline & Pozitivni & 75 & $83,3 \mathrm{I}$ & 6248,00 \\
\hline & Izenačeni & 9 & & \\
\hline & Skupaj & 166 & & \\
\hline \multirow{4}{*}{ D - povezovalne sile organizacije } & Negativni & 67 & 63,22 & 4235,50 \\
\hline & Pozitivni & 93 & 92,95 & 8644,50 \\
\hline & Izenačeni & 61 & & \\
\hline & Skupaj & 166 & & \\
\hline
\end{tabular}

Pri dimenziji Povezovalne sile organizacije pri tipih kulture A in C (preglednica 8.19) razlike v povprečjih ne obstajajo $(\mathrm{p}>0,05)$. Prevladujeta tipa $\mathrm{B}(\mathrm{p}<0,05, \mathrm{Z}=-7,325)$ in $\mathrm{D}(\mathrm{p}<0,05, \mathrm{Z}=-3,760)$.

Preglednica 8.19: Testna statistika - povezovalne sile organizacijc

\begin{tabular}{lcccc} 
& $\begin{array}{c}\text { A-povezovalne sile } \\
\text { organizacije }\end{array}$ & $\begin{array}{c}\mathrm{B} \text { - povezovalne sile } \\
\text { organizacije }\end{array}$ & $\begin{array}{c}\mathrm{C} \text { - povezovalne sile } \\
\text { organizacije }\end{array}$ & $\begin{array}{c}\mathrm{D} \text { - povezovalne sile } \\
\text { organizacije }\end{array}$ \\
\hline $\mathrm{Z}$ & $-\mathrm{I}, 168 \mathrm{~b}$ & $-7,325 \mathrm{~b}$ &,$- 082 \mathrm{C}$ & $-3,760 \mathrm{C}$ \\
\hline $\begin{array}{l}\text { Asomptimatična } \\
\text { p-vrednost } \\
(2 \text {-stranska) }\end{array}$ &, 243 &, 000 &, 935 &, 000 \\
\hline
\end{tabular}


Preglednica 8.20: Rangi - strateški poudarki

\begin{tabular}{|c|c|c|c|c|}
\hline \multicolumn{5}{|c|}{ Rangi } \\
\hline & & $\mathbf{N}$ & Povprečje rangov & Vsota rangov \\
\hline \multirow{4}{*}{ A - strateški poudarki } & Negativni & 96 & 79,67 & 7648,00 \\
\hline & Pozitivni & 70 & 88,76 & 6213,00 \\
\hline & Izenačeni & $\circ$ & & \\
\hline & Skupaj & 166 & & \\
\hline \multirow{4}{*}{ B - strateški poudarki } & Negativni & 129 & 85,09 & 10977,00 \\
\hline & Pozitivni & 33 & 67,45 & 2226,00 \\
\hline & Izenačeni & 4 & & \\
\hline & Skupaj & 166 & & \\
\hline \multirow{4}{*}{ C-strateški poudarki } & Negativni & 82 & 74,82 & 6135,00 \\
\hline & Pozitivni & 75 & 83,57 & 6268,00 \\
\hline & Izenačeni & 9 & & \\
\hline & Skupaj & 166 & & \\
\hline \multirow{4}{*}{ D - strateški poudarki } & Negativni & 67 & 63,21 & 4235,00 \\
\hline & Pozitivni & 93 & 92,96 & 8645,00 \\
\hline & Izenačeni & 6 & & \\
\hline & Skupaj & 166 & & \\
\hline
\end{tabular}

Pri dimenziji Strateški poudarki pri tipih kulture A in C (preglednica 8.2I) razlike v povprečjih ne obstajajo $(\mathrm{p}>0,05)$. Prevladujeta tipa $\mathrm{B}(\mathrm{p}<$ $0,05, Z=-7,325)$ in $\mathrm{D}(\mathrm{p}<0,05, \mathrm{Z}=-3,76 \mathrm{I})$.

Preglednica 8.21: Testna statistika - strateški poudarki

\begin{tabular}{|c|c|c|c|c|}
\hline & $\begin{array}{c}\text { A - } \\
\text { strateški poudarki }\end{array}$ & $\begin{array}{c}\text { B - } \\
\text { strateški poudarki }\end{array}$ & $\begin{array}{c}\text { C- } \\
\text { strateški poudarki }\end{array}$ & $\begin{array}{c}\text { D - } \\
\text { strateški poudarki }\end{array}$ \\
\hline Z & $-1,158 b$ & $-7,325 \mathrm{~b}$ &,$- 117 \mathrm{c}$ & $-3,76 \mathrm{Ic}$ \\
\hline $\begin{array}{l}\text { Asomptimat } \\
\text { p-vrednost } \\
\text { (2-stranska) }\end{array}$ & ,247 & , , & 907, & , \\
\hline
\end{tabular}


Organizacijska kultura in organizacijska klima

Preglednica 8.22: Rangi - merilo uspeha

\begin{tabular}{|c|c|c|c|c|}
\hline \multicolumn{5}{|c|}{ Rangi } \\
\hline & & $\mathbf{N}$ & Povprečje rangov & Vsota rangov \\
\hline \multirow{4}{*}{ A - merilo uspeha } & Negativni & 97 & 78,91 & 7654,00 \\
\hline & Pozitivni & 69 & 89,96 & 6207,00 \\
\hline & Izenačeni & $\circ$ & & \\
\hline & Skupaj & 166 & & \\
\hline \multirow{4}{*}{ B - merilo uspeha } & Negativni & 129 & 85,09 & 10977,00 \\
\hline & Pozitivni & 33 & 67,45 & 2226,00 \\
\hline & Izenačeni & 4 & & \\
\hline & Skupaj & 166 & & \\
\hline \multirow{4}{*}{$\mathrm{C}$ - merilo uspeha } & Negativni & 82 & 75,06 & 6155,00 \\
\hline & Pozitivni & 75 & 83,31 & 6248,00 \\
\hline & Izenačeni & 9 & & \\
\hline & Skupaj & 166 & & \\
\hline \multirow{4}{*}{ D - merilo uspeha } & Negativni & 67 & 63,22 & 4235,50 \\
\hline & Pozitivni & 93 & 92,95 & 8644,50 \\
\hline & Izenačeni & 6 & & \\
\hline & Skupaj & 166 & & \\
\hline
\end{tabular}

Pri dimenziji Merilo uspeha pri tipih kulture A in C (preglednica 8.23) razlike $v$ povprečjih ne obstajajo $(\mathrm{p}>0,05)$. Prevladujeta tipa $\mathrm{B}(\mathrm{p}<$ $0,05, \mathrm{Z}=-7,325)$ in $\mathrm{D}(\mathrm{p}<0,05, \mathrm{Z}=-3,760)$.

Preglednica 8.23: Testna statistika - merilo uspeha

\begin{tabular}{lcccc} 
& $\begin{array}{c}\text { A - } \\
\text { merilo uspeha }\end{array}$ & $\begin{array}{c}\mathrm{B}- \\
\text { merilo uspeha }\end{array}$ & $\begin{array}{c}\mathrm{C}- \\
\text { merilo uspeha }\end{array}$ & $\begin{array}{c}\mathrm{D}- \\
\text { merilo uspeha }\end{array}$ \\
\hline $\mathrm{Z}$ & $-1,168 \mathrm{~b}$ & $-7,325 \mathrm{~b}$ &,$- 082 \mathrm{C}$ & $-3,760 \mathrm{C}$ \\
\hline $\begin{array}{l}\text { Asomptimatična } \\
\text { p-vrednost } \\
(2 \text {-stranska) }\end{array}$ &, 243 & & &, 000 \\
\hline
\end{tabular}

Vidimo, da je tip kulture skladen pri vseh šestih dimenzijah. Pri tipu kulture $A$ in $C$ razlike v povprečjih ne obstajajo ( $p>0,05)$. Prevladujeta tipa $B$ in D pri vseh dimenzijah $(\mathrm{p}<0,05)$. Hipotezo 2 potrdimo. 
Hipoteza 3: Obstaja razlika v dojemanju tipa organizacijske kul-

ture med splošnim, tehničnim in umetniškim sektorjem.

$S$ pomočjo diskriminantne analize smo preverili statistično pomembnost razlik v tipu zaznane organizacijske kulture med vsemi tremi sektorji.

Diskriminantna analiza je metoda v multivariatni analizi, $s$ katero se poiščejo linearne kombinacije opazovanih spremenljivk, ki ločujejo vnaprej določene skupine tako, da je napaka pri uvrščanju v skupine najmanjša. Iskali smo razsežnost podatkov, ki najbolje pojasnjuje razlike med skupinami.

Vse trditve, A, B, C, D, v vseh dimenzijah smo združili v eno vrednost in izračunali povprečje.

Preglednica 8.24: Vrednosti OCAI - sedanje stanje

\begin{tabular}{ccccccc}
\multirow{2}{*}{$\begin{array}{c}\text { Tip } \\
\text { kulture }\end{array}$} & Veljavni & Manjkajoči & Povprečje & Mediana & Modus & $\begin{array}{c}\text { Standardni } \\
\text { odklon }\end{array}$ \\
\cline { 2 - 3 } A & 166 & 0 & 23,83 & 22,08 & 31,67 & 11,27 \\
\hline B & 166 & 0 & 20,32 & 20,00 & 12,50 & 6,74 \\
\hline C & 166 & 0 & 25,80 & 25,00 & 15,00 & 10,13 \\
\hline D & 166 & 0 & 30,05 & 26,67 & 20,83 & 11,76 \\
\hline
\end{tabular}

Najvišje povprečje $(30,05)$ je pri kulturi hierarhije, sledi organizacijska kultura trga $(25,80)$, nato organizacijska kultura klana $(23,83)$, najnižje povprečje pa se kaže pri organizacijski kulturi adhokracije $(20,32)$ preglednica 8.24. Standardni odkloni/odstopanja od povprečja so velika.

Gledališča so razdeljena na tri organizacijske enote - sektorje: umetniški, tehnični in splošni. Ti nastopajo kot faktorji, tipi kulture pa kot neodvisne spremenljivke (preglednica 26). 
Organizacijska kultura in organizacijska klima

\section{Preglednica 8.25: Statistika skupin}

\begin{tabular}{|c|c|c|c|c|c|}
\hline & \multirow{2}{*}{ Sektor } & \multirow{2}{*}{ Povprečje } & \multirow{2}{*}{$\begin{array}{c}\text { Standardni } \\
\text { odklon }\end{array}$} & \multicolumn{2}{|c|}{$\mathbf{N}$} \\
\hline & & & & Brez uteži & Uteži \\
\hline \multirow{4}{*}{ Umetniški } & A & 20,83 & 9,07 & 55 & 55,00 \\
\hline & $\mathrm{B}$ & 21,06 & 4,28 & 55 & 55,00 \\
\hline & $\mathrm{C}$ & 29,79 & 10,40 & 55 & 55,00 \\
\hline & $\mathrm{D}$ & 28,32 & 8,78 & 55 & 55,00 \\
\hline \multirow{4}{*}{ Tehnični } & $\mathrm{A}$ & 25,40 & 13,00 & 42 & 42,00 \\
\hline & B & 19,58 & 7,77 & 42 & 42,00 \\
\hline & $\mathrm{C}$ & 26,23 & $1 \mathrm{II}, 72$ & 42 & 42,00 \\
\hline & $\mathrm{D}$ & 28,79 & 12,29 & 42 & 42,00 \\
\hline \multirow{4}{*}{ Splošni } & $\mathrm{A}$ & 25,25 & $\mathrm{II}, 4 \mathrm{O}$ & 69 & 69,00 \\
\hline & B & 20,18 & 7,66 & 69 & 69,00 \\
\hline & $\mathrm{C}$ & 22,37 & 7,43 & 69 & 69,00 \\
\hline & $\mathrm{D}$ & 32,20 & 13,24 & 69 & 69,00 \\
\hline \multirow{4}{*}{ Skupaj } & A & 23,83 & II, 27 & 166 & 166,00 \\
\hline & $\mathrm{B}$ & 20,32 & 6,74 & I 66 & 166,00 \\
\hline & $\mathrm{C}$ & 25,80 & $\mathrm{IO}, \mathrm{I3}$ & I 66 & 166,00 \\
\hline & $\mathrm{D}$ & 30,05 & 11,76 & 166 & 166,00 \\
\hline
\end{tabular}

$\mathrm{V}$ preglednici 8.25 vidimo, da so standardni odkloni/odstopanja od povprečja kar velika.

Preglednica 8.26: Test enakosti povprečja skupin

\begin{tabular}{cccccc} 
& Wilksova lambda & F & dfi & df2 & p-vrednost \\
\hline A & 965 & 2,972 & 2 & 163 &, 054 \\
\hline B & 993 &, 594 & 2 & 163 &, 553 \\
\hline C & 900 & 9,081 & 2 & 163 &, 000 \\
\hline D & 9976 & 2,014 & 2 & 163 &, 137 \\
\hline
\end{tabular}

Idealen rezultat bi bil, če bi bil test Wilksove lambde statistično značilen za vse tipe kulture. P-vrednost mora biti manjša od o,05. To je le pri tipu kulture C.

Poglejmo še znotrajskupinsko matriko. Višje vrednosti pomenijo, da so tipi kulture med seboj močno povezani (preglednica 8.27). 
Preglednica 8.27: Znotrajskupinska matrika

\begin{tabular}{cccccc}
\multicolumn{2}{c}{ Tip kulture } & A & B & C & D \\
& A & I,000 &, 444 &,- 608 &,- 706 \\
\cline { 2 - 5 } Korelacija & B &, 444 & 1,000 & -477 &,- 607 \\
\cline { 2 - 6 } & C &,- 608 &,- 477 & 1,000 &, 028 \\
\cline { 2 - 6 } & D &,,- 706 &,- 607 &, 028 & 1,000 \\
\hline
\end{tabular}

Preglednica 8.28: Log dejavniki

\begin{tabular}{|c|c|c|}
\hline Sektor & Rang & Log dejavniki \\
\hline Umetniški & 3 & 11,196 \\
\hline Tehnični & 3 & I2,995 \\
\hline Splošni & 3 & $\mathrm{I} 2,314$ \\
\hline Znotraj skupin & 3 & 12,410 \\
\hline
\end{tabular}

Log dejavniki nam kažejo, da so vrednosti med sektorji zelo podobne; vidimo, da med skupinami ni bistvenih razlik.

Testiramo še ničelno hipotezo o enakosti kovariančne matrike.

Preglednica 8.29: Testni rezultati

\begin{tabular}{|c|c|c|}
\hline \multicolumn{2}{|c|}{ Kvadrat M } & 48,05 \\
\hline \multirow{4}{*}{$\mathrm{F}$} & Aproksimatičnost & 3,89 \\
\hline & $d f_{I}$ & 12,00 \\
\hline & $\mathrm{df}_{2}$ & 91618,77 \\
\hline & p-vrednost & ০,০০ \\
\hline
\end{tabular}

Ugotovimo, da je p-vrednost pod o,05, in potrdimo ničelno hipotezo o enakosti kovariančne matrike. Med sektorji ni razlike. Hipotezo 3 zavrnemo. Sektorji nimajo pomembnega vpliva. 


\begin{tabular}{cccc} 
& & Sektor & \\
\cline { 2 - 4 } & Umetniški & Tehnični & Splošni \\
\hline $\mathrm{A}$ &, 425 &, 464 &, 429 \\
\hline $\mathrm{B}$ &, 738 &, 649 &, 641 \\
\hline $\mathrm{C}$ &, 862 &, 823 &, 754 \\
\hline (Konstanta) & $-26,139$ & $-24,143$ & $-21,420$ \\
\hline
\end{tabular}

Vidimo pa, da ne moremo govoriti o statistični značilnosti med tipi kulture in sektorji, ker so p-vrednosti višje od o,05. Sektorji nimajo pomembnega vpliva.

Hipoteza 4: Obstaja statistično značilna povezanost med tipi organizacijske kulture in dejavniki zadovoljstva pri delu in $z$ delovnimi razmerami.

$S$ pomočjo faktorske analize smo izračunali faktorje - dejavnike zadovoljstva. Za analizo povezanosti med posameznimi tipi organizacijske kulture (za sedanje in želeno stanje) in dejavnikov zadovoljstva smo izvedli korelacijsko analizo s Pearsonovim korelacijskim koeficientom (r).

Preglednica 8.31: Osnovna statistika

\begin{tabular}{lccc}
\multicolumn{1}{c}{ Trditve } & Povprečje & Standardni odklon & N \\
\hline Vodje oddelkov so primerno usposobljeni za svoje delo. & 3,64 & 0,64 & 165 \\
\hline Moj neposredno nadrejeni dobro opravlja svoje naloge. & 3,32 & 0,84 & 165 \\
\hline Kakovost vodenja je dobra. & 3,32 & 0,83 & 165 \\
\hline $\begin{array}{l}\text { Vodje posredujejo dovolj povratnih informacij o delu } \\
\text { zaposlenih. }\end{array}$ & 3,18 & 0,87 & 165 \\
\hline $\begin{array}{l}\text { Pretok informacij od vodij do zaposlenih poteka dobro. } \\
\text { Nadrejeni mi dajejo primerne informacije o tem, kaj naj }\end{array}$ & 3,25 & 0,72 & 165 \\
\hline bi delal(a). & 3,30 & 0,88 & 165 \\
\hline $\begin{array}{l}\text { Seznanjen sem s tem, katerim vidikom mojega dela daje- } \\
\text { jo predpostavljeni največji poudarek pri oceni moje de- } \\
\text { lovne uspešnosti. }\end{array}$ & 3,14 & 1,13 & 165 \\
\hline Za dobro opravljeno delo sem ustrezno pohvaljen(a). & 3,02 & 1,09 & 165 \\
\hline Nagrajevanje je pravično. & 2,84 & 1,08 & 165 \\
\hline Če naredim kaj narobe, sem opozorjen. & 4,32 & 0,71 & 165 \\
\hline \begin{tabular}{l} 
Za svoje delo prejemam ustrezno plačilo. \\
\hline
\end{tabular} & 3,08 & 0,75 & 165 \\
\hline
\end{tabular}


Vodja me za moj trud pri delu (predlogi za izboljšave/inovativnost) zna pohvaliti.

$3,32 \quad 1,01 \quad 16$

S sodelavci se dobro razumem.

Svojega nadrejenega cenim in spoštujem.

$3,99 \quad 0,63 \quad 165$

Moji predpostavljeni mi izkazujejo primerno spoštovanje.

3,76

$0,86 \quad 165$

Z nadrejenim se dobro razumem.

Za naš oddelek so značilni sodelovanje, pomoč in tovarištvo.

\begin{tabular}{|c|c|c|c|}
\hline $\begin{array}{l}\text { V našem oddelku je pogosto opaziti neizrečene zamere in } \\
\text { užaljenost. }\end{array}$ & 2,39 & 0,98 & 165 \\
\hline V našem oddelku je pogosto opaziti zavist med sodelavci. & 2,54 & $\mathrm{I}, \mathrm{O} 3$ & 165 \\
\hline $\begin{array}{l}\text { V našem oddelku je pogosto mogoče zaznati nepripravl- } \\
\text { jenost za sodelovanje. }\end{array}$ & 2,28 & 0,90 & 165 \\
\hline V našem oddelku prevladuje dobro razpoloženje. & 3,54 & 0,89 & 165 \\
\hline Za naš oddelek je značilno dobro timsko delo. & 3,59 & 0,85 & 165 \\
\hline Imam možnosti za usposabljanje na področju svojega dela. & 2,73 & $\mathrm{I}, 20$ & 165 \\
\hline Delo je enolično, dolgočasno, premalo zanimivo. & 2,06 & 0,98 & 165 \\
\hline $\begin{array}{l}\text { Inovativnost, izboljšave in ustvarjalnost so na oddelku zaže- } \\
\text { lene. }\end{array}$ & 3,32 & 1,26 & 165 \\
\hline Menim, da sem premalo usposobljen(a) za svoje delo. & 1,98 & $\mathrm{I}, \mathrm{O} 3$ & 165 \\
\hline Strokovna usposabljanja so dovolj pogosto organizirana. & $2,4 \mathrm{I}$ & 1,02 & 165 \\
\hline $\begin{array}{l}\text { Pri delu imam na voljo sredstva, ki so potrebna, da ga do- } \\
\text { bro opravim. }\end{array}$ & 3,71 & 1,09 & 165 \\
\hline $\begin{array}{l}\text { Delo mi omogoča, da pokažem svoje sposobnosti in znan- } \\
\text { je. }\end{array}$ & 3,77 & 0,67 & 165 \\
\hline Delo me veseli in mi daje osebno zadovoljstvo. & 3,93 & 0,75 & 165 \\
\hline $\begin{array}{l}\text { Po opravljenem delu imam občutek, da sem nekaj } \\
\text { dosegel/-la. }\end{array}$ & 3,85 & 0,84 & 165 \\
\hline Količina in obseg dela, ki ga opravljam, sta zame primerna. & $3,4 \mathrm{I}$ & 0,84 & 165 \\
\hline Razpored delovnega časa je ustrezen. & 3,35 & $\mathrm{I}, 00$ & 165 \\
\hline Z delom, ki ga opravljam, sem zadovoljen/-na. & 4,16 & 0,66 & 165 \\
\hline $\begin{array}{l}\text { Tam, kjer je to mogoče, lahko odločam o tem, kako in kaj } \\
\text { bom naredil(a). }\end{array}$ & $4, \infty 0$ & 0,74 & 165 \\
\hline O načinu razrešitve problemov odloča vodja sam. & 3,13 & 0,92 & 165 \\
\hline $\begin{array}{l}\text { O načinu razrešitve problemov odloča vodja skupaj s } \\
\text { sodelavci. }\end{array}$ & 3,51 & 0,84 & 165 \\
\hline Delovni pogoji za moje delo so primerni. & 3,53 & 0,84 & 165 \\
\hline Moja služba negativno vpliva na moje življenje. & 2,44 & 0,98 & 165 \\
\hline
\end{tabular}


Povprečne vrednosti odgovorov na trditve nam kažejo, da so zaposleni ocenili, da najbolj drži trditev, da so opozorjeni, če naredijo kaj narobe $(4,32)$, in da so $z$ delom, ki ga opravljajo, zadovoljni $(4,16)$, ter da tam, kjer je mogoče, lahko odločajo o tem, kaj in kako bodo naredili $(4,00)$. Najmanj pa držijo trditve, da so premalo usposobljeni za svoje delo $(\mathrm{I}, 98)$, da je delo enolično, dolgočasno in premalo zanimivo $(2,06)$. Ugotovimo lahko, da so zaposleni srednje zadovoljni z delom in delovnimi razmerami, saj je povprečna ocena vseh odgovorov 3,29 (na lestvici od I do 5).

V faktorsko analizo smo vključili 39 spremenljivk. Zanima nas, če so mogoče indikatorji za kakšne latentne spremenljivke. Na osnovi diagrama lastnih vrednosti (slika ıo), ki je eden od načinov za določitev števila faktorjev, sklepamo, da gre za tri faktorje. Faktorski model je identifikabilen, saj je predpostavljenih faktorjev veliko manj kot spremenljivk.

$S$ pomočjo faktorske analize smo spremenljivkam določili skupne faktorje. Faktorska analiza določi, katera od 39 vprašanj imajo toliko skupnega, da jih lahko obravnavamo kot en sklop oziroma en faktor.

Preglednica 8.32: Komponentna matrika

\begin{tabular}{|c|c|c|c|}
\hline \multicolumn{4}{|l|}{ Komponentna matrika } \\
\hline & \multicolumn{3}{|c|}{ Komponentna } \\
\hline & Faktor I & Faktor 2 & Faktor 2 \\
\hline Vodje oddelkov so primerno usposobljeni za svoje delo. &, 459 &,- 439 &,- 246 \\
\hline Moj neposredno nadrejeni dobro opravlja svoje naloge. & 599 &, 094 &,- 236 \\
\hline Kakovost vodenja je dobra. &, 779 &, 072 &,- 321 \\
\hline Vodje posredujejo dovolj povratnih informacij o delu zaposlenih. & .558 &,- 278 & 408 \\
\hline Pretok informacij od vodij do zaposlenih poteka dobro. & ,633 &,- 390 &, 322 \\
\hline Nadrejeni mi dajejo primerne informacije o tem, kaj naj bi delal(a). &, 778 & ,019 &,- 113 \\
\hline $\begin{array}{l}\text { Seznanjen sem s tem, katerim vidikom mojega dela dajejo predpostavl- } \\
\text { jeni največji poudarek pri oceni moje delovne uspešnosti. }\end{array}$ &, 711 & 407 &,- 093 \\
\hline Za dobro opravljeno delo sem ustrezno pohvaljen(a). &, 733 &, 367 &, 052 \\
\hline Nagrajevanje je pravično. &, 497 &, 500 &,$- \mathrm{OOI}$ \\
\hline Če naredim kaj narobe, sem opozorjen. &, 195 &, 268 & .537 \\
\hline Za svoje delo prejemam ustrezno plačilo. &, 529 &, $\mathrm{II7}$ &,- 213 \\
\hline
\end{tabular}




\section{Komponentna matrika}

Komponentna

Faktor 1 Faktor $2 \quad$ Faktor 2

Vodja me za moj trud pri delu (predlogi za izboljšave/inovativnost) zna pohvaliti.

\begin{tabular}{|c|c|c|c|}
\hline S sodelavci se dobro razumem. &, 413 &,- 696 &,- 228 \\
\hline Svojega nadrejenega cenim in spoštujem. & 647 &,- 138 &,- 395 \\
\hline Moji predpostavljeni mi izkazujejo primerno spoštovanje. &, 813 &, 038 &,- 377 \\
\hline Znadrejenim se dobro razumem. &, $75^{8}$ &, 223 &,- 266 \\
\hline Za naš oddelek so značilni sodelovanje, pomoč in tovarištvo. & .556 &,- 269 &, 443 \\
\hline V našem oddelku je pogosto opaziti neizrečene zamere in užaljenost. &, 244 &,- 046 & ,646 \\
\hline V našem oddelku je pogosto opaziti zavist med sodelavci. &, 522 &,- 236 &, 582 \\
\hline $\begin{array}{l}\text { V našem oddelku je pogosto mogoče zaznati nepripravljenost za } \\
\text { sodelovanje. }\end{array}$ & 416 &,- 186 &, 687 \\
\hline V našem oddelku prevladuje dobro razpoloženje. & 600 &,- 415 &, 327 \\
\hline Za naš oddelek je značilno dobro timsko delo. &, 557 &,- 520 &, 304 \\
\hline Imam možnosti za usposabljanje na področju svojega dela. &, 400 &, 664 &,- 152 \\
\hline Delo je enolično, dolgočasno, premalo zanimivo. &,- 325 &, 208 &, $\mathrm{137}$ \\
\hline Inovativnost, izboljšave in ustvarjalnost so na oddelku zaželene. & ,680 &,$- \mathrm{OIO}$ &, 334 \\
\hline Menim, da sem premalo usposobljen(a) za svoje delo. &,- 020 & .550 &, 260 \\
\hline Strokovna usposabljanja so dovolj pogosto organizirana. &, 013 & ,676 &, 177 \\
\hline Pri delu imam na voljo sredstva, ki so potrebna, da ga dobro opravim. & 364 &, $55^{\mathrm{I}}$ &, 462 \\
\hline Delo mi omogoča, da pokažem svoje sposobnosti in znanje. & 655 &, 177 &, 043 \\
\hline Delo me veseli in mi daje osebno zadovoljstvo. &, 372 &,- 238 &,- 204 \\
\hline Po opravljenem delu imam občutek, da sem nekaj dosegel/-la. &, 632 &, 075 &, 062 \\
\hline Količina in obseg dela, ki ga opravljam, sta zame primerna. &, $24 \mathrm{I}$ &, 600 &, 006 \\
\hline Razpored delovnega časa je ustrezen. & , 189 &,- 188 &,- 566 \\
\hline Z delom, ki ga opravljam, sem zadovoljen/-na. &, 488 & .555 &,- 127 \\
\hline $\begin{array}{l}\text { Tam, kjer je to mogoče, lahko odločam o tem, kako in kaj bom nare- } \\
\operatorname{dil}(\text { a). }\end{array}$ &, 723 &, 089 &,- 266 \\
\hline O načinu razrešitve problemov odloča vodja sam. &, 585 &,- 399 & ,129 \\
\hline O načinu razrešitve problemov odloča vodja skupaj s sodelavci. &, 622 &, 062 & $40 \mathrm{I}$ \\
\hline Delovni pogoji za moje delo so primerni. &, 430 &,- 322 &,- 525 \\
\hline Moja služba negativno vpliva na moje življenje. &, 226 &,- 015 &,$- 45^{8}$ \\
\hline
\end{tabular}

Dobljene rešitve (preglednica 8.32) ne moremo dobro interpretirati, zato smo za ocenjevanje faktorskih uteži uporabili rotacije. Namen teh je 
poenostavitev faktorskega modela. Faktorska rotacija je postopek, s katerim se določa nove skupne faktorje zaradi pridobitve enostavne strukture in poenostavitve razlage skupnih faktorjev. Dobljena rešitev ravno tako dobro predstavlja podatke. Uporabimo jo, če skupnih faktorjev ne moremo smiselno interpretirati. Izvedli smo pravokotno rotacijo. Rotirane faktorske uteži (po Varimaxu) prikazuje preglednica 8.33.

Preglednica 8.33: Pravokotna rotacija faktorjev zadovoljstva zaposlenih

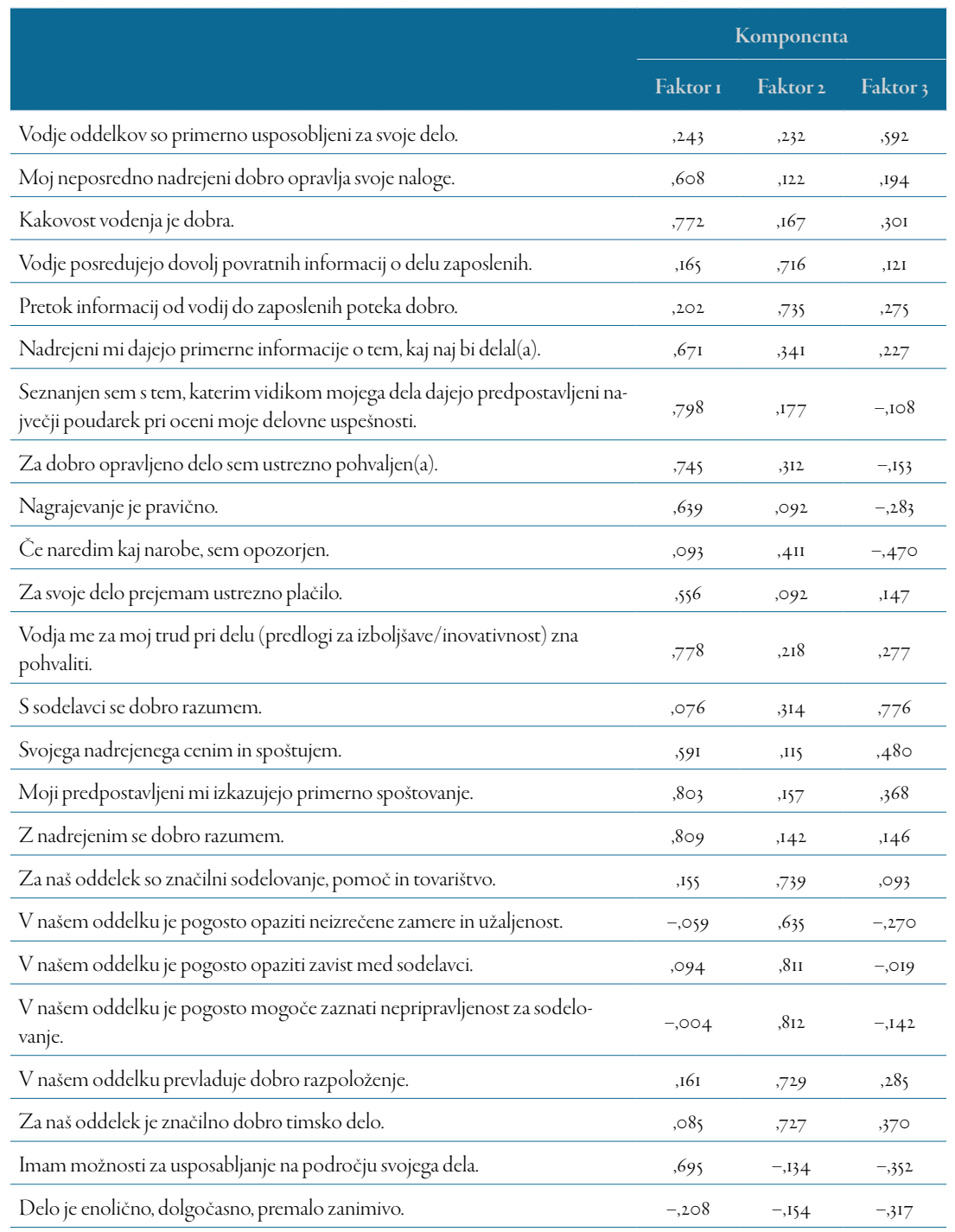




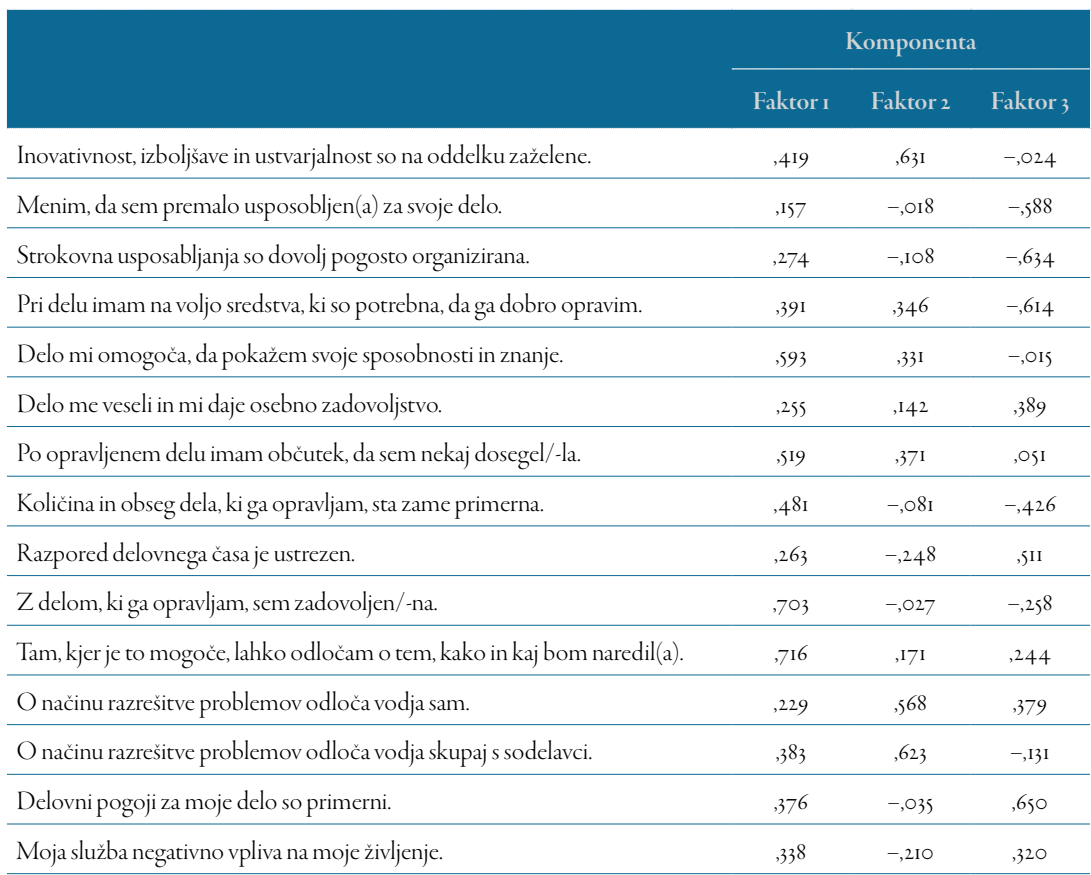

Trditve smo uvrstili v tisto skupino (faktor), kjer je vrednost faktorske uteži največja.

Prvi faktor smo poimenovali vodenje, nagrajevanje in delovni pogoji. Zanj so razvidne visoke faktorske uteži, da moj neposredno nadrejeni dobro opravlja svoje naloge $(0,608)$, da je kakovost vodenja dobra $(0,772)$, da nadrejeni zaposlenim dajejo primerne informacije o tem, kaj naj bi delali $(0,67 \mathrm{I})$, da so zaposleni seznanjeni $s$ tem, katerim vidikom njihovega dela dajejo predpostavljeni največji poudarek pri oceni delovne uspešnosti $(0,798)$, da so zaposleni za dobro opravljeno delo ustrezno pohvaljeni $(0,745)$, da je nagrajevanje pravično $(0,639)$, da za svoje delo prejema ustrezno plačilo $(0,556)$, da vodja zaposlene za njihov trud pri delu (predlogi za izboljšave/inovativnost) zna pohvaliti $(0,778)$, da zaposleni svojega nadrejenega cenijo in spoštujejo (0,59I), da predpostavljeni sodelavcem izkazujejo primerno spoštovanje $(0,803)$, da se $\mathrm{z}$ nadrejenim dobro razumejo $(0,809)$, da imajo možnosti za usposabljanje na področju svojega dela $(0,695)$, da imajo pri delu na voljo sredstva, ki so potrebna, da ga dobro opravijo $(0,39 \mathrm{I})$, da jim delo omogoča, da pokažejo svoje sposobnosti in znanje (0,593), da imajo po opravljenem delu občutek, da so nekaj dosegli (0,519), da sta količina in obseg dela, ki ga opravljajo, zanje primerna $(0,48 \mathrm{I})$, da so z delom, ki ga opravljajo, zadovoljni $(0,703)$, da tam, kjer 
je to mogoče, lahko zaposleni sami odločajo o tem, kako in kaj bodo naredili (o,716), da služba negativno vpliva na življenje zaposlenih $(0,338)$.

Drugi faktor smo poimenovali sodelovanje in odnosi. Vanj so se uvrstile naslednje spremenljivke z visokimi faktorskimi utežmi: vodje posredujejo dovolj povratnih informacij o delu zaposlenih $(0,716)$, pretok informacij od vodij do zaposlenih poteka dobro $(0,735)$, če naredim kaj narobe, sem opozorjen $(0,4 \mathrm{II})$, za naš oddelek so značilni sodelovanje, pomoč in tovarištvo $(0,739)$, v našem oddelku je pogosto opaziti neizrečene zamere in užaljenost $(0,635)$, v našem oddelku je pogosto opaziti zavist med sodelavci $(0,8 \mathrm{II})$, v našem oddelku je pogosto mogoče zaznati nepripravljenost za sodelovanje $(0,8 \mathrm{I} 2)$, v našem oddelku prevladuje dobro razpoloženje $(0,729)$, za naš oddelek je značilno dobro timsko delo $(0,727)$, inovativnost, izboljšave in ustvarjalnost so na oddelku zaželene (o,63I), o načinu razrešitve problemov odloča vodja sam $(0,568)$, o načinu razrešitve problemov odloča vodja skupaj s sodelavci $(0,623)$.

Tretji faktor smo poimenovali motiviranost za delo. Vanj so se uvrstile naslednje spremenljivke $\mathrm{z}$ najvišjimi faktorskimi utežmi: vodje oddelkov so primerno usposobljeni za svoje delo $(0,592)$, s sodelavci se dobro razumem (o,776), delo me veseli in mi daje osebno zadovoljstvo (o,389), razpored delovnega časa je ustrezen $(0,5 \mathrm{II})$, delovni pogoji za moje delo so primerni $(0,650)$.

Preglednica 8.34: Korelacije med faktorji pri pravokotni rotaciji

\begin{tabular}{lccc}
\multicolumn{1}{c}{ Komponenta } & Faktor I & Faktor 2 & Faktor 3 \\
Faktor 1 &, 799 &, 556 &, 229 \\
\hline Faktor 2 &, 483 &,- 366 &,- 796 \\
\hline Faktor 3 &,- 358 &, 746 &,- 561 \\
\hline
\end{tabular}

Za testiranje naše hipoteze, da obstaja statistično značilna povezanost med tipi organizacijske kulture in dejavniki zadovoljstva pri delu ter z delovnimi razmerami, smo izvedli korelacijsko analizo s Pearsonovim korelacijskim koeficientom (r). Ugotavljali smo povezanost med spremenljivkami: tipi kulture (A - klan, B - adhokracija, C - trg, D - hierarhija) in dejavniki zadovoljstva (faktor I - vodenje, nagrajevanje in delovni pogoji, faktor 2 - sodelovanje in odnosi, faktor 3 - motiviranost za delo), in sicer dvakrat; prvič za sedanje stanje zaznanih tipov organizacijske kulture in drugič za želeno stanje tipov organizacijske kulture.

Iz preglednice 8.35 , ki prikazuje Pearsonov korelacijski koeficient, njegovo stopnjo značilnosti in število veljavnih enot, vidimo, da med 
spremenljivkami dejavniki zadovoljstva $\mathrm{z}$ delom in delovnimi razmerami ter tipi organizacijske kulture - sedanje stanje ni povezanosti. Pearsonov koeficient povezanosti je neznačilen, saj p-vrednosti presegajo vrednosti 0,05 .

Preglednica 8.35: Povezanost dejavnikov zadovoljstva in tipov organizacijske kulture - sedanje stanje

\begin{tabular}{|c|c|c|c|c|c|}
\hline & & A & B & $\mathrm{C}$ & D \\
\hline \multirow{3}{*}{ Faktor I } & Pearsonov koeficient korelacije &, 038 & ,124 &,- 146 & ,018 \\
\hline & Asimp.p-vrednost (2-stranska) &, 632 & ,II3 &, 062 &, 814 \\
\hline & $\mathrm{N}$ & 165 & 165 & 165 & 165 \\
\hline \multirow{3}{*}{ Faktor 2} & Pearsonov koeficient korelacije &,- 070 &,- 059 & , 888 &, 025 \\
\hline & Asimp.p-vrednost (2-stranska) &, 371 &, 455 &, 263 &, 751 \\
\hline & $\mathrm{N}$ & 165 & 165 & 165 & 165 \\
\hline \multirow{3}{*}{ Faktor 3} & Pearsonov koeficient korelacije &,- 031 &,- 025 &,- 005 &, 048 \\
\hline & Asimp.p-vrednost (2-stranska) & 690 &, 747 & ,951 &, 537 \\
\hline & $\mathrm{N}$ & 165 & 165 & 165 & 165 \\
\hline
\end{tabular}

Enak test smo naredili še za ugotavljanje povezanosti med dejavniki zadovoljstva $\mathrm{z}$ delom in delovnimi razmerami ter tipi organizacijske kulture za želeno stanje.

Preglednica 8.36: Povezanost dejavnikov zadovoljstva in tipov organizacijske kulture - želeno stanje

\begin{tabular}{|c|c|c|c|c|c|}
\hline & & A & B & $\mathrm{C}$ & D \\
\hline \multirow{3}{*}{ Faktor I } & Pearsonov koeficient korelacije &, 016 &, $168^{*}$ &,- 163 &,$- \mathrm{OI} 4$ \\
\hline & Asimp. p-vrednost (2-stranska) &, 836 &, 032 &, 036 & 855 \\
\hline & $\mathrm{N}$ & 165 & 165 & 165 & 165 \\
\hline \multirow{3}{*}{ Faktor 2} & Pearsonov koeficient korelacije &, 084 &, 056 &,- 076 &,- 114 \\
\hline & Asimp.p-vrednost (2-stranska) &, $28 \mathrm{I}$ &, 479 &, 334 & , 145 \\
\hline & $\mathrm{N}$ & 165 & 165 & 165 & 165 \\
\hline \multirow{3}{*}{ Faktor 2} & Pearsonov koeficient korelacije &, 032 &,$- \mathrm{IO} 2$ &, 027 &, 023 \\
\hline & Asimp.p-vrednost (2-stranska) & $68 \mathrm{I}$ &, $\mathrm{I} 9 \mathrm{I}$ &, 732 &, 771 \\
\hline & $\mathrm{N}$ & 165 & 165 & 165 & 165 \\
\hline
\end{tabular}

Pearsonov koeficient je statistično značilen, kjer p-vrednost ne presega vrednosti o,05. Vidimo, da je to pri povezanosti faktorja I - vode- 
nje, nagrajevanje in delovni pogoji in tipov kulture C (kultura trga) ter B (kultura adhokracije), kjer pa gre le za neznatno povezanost (na lestvici od o do I, kjer o pomeni, da ni povezanosti, ০,or-০,or 9 pomeni neznatno povezanost, $, 0,02-0,039$ pomeni šibko povezanost, ..., ০,०9-0,99 pomeni močno povezanost, I pomeni popolno povezanost).

Ugotavljamo, da ne obstaja statistično značilna povezanost med tipi organizacijske kulture (A - klan, B - adhokracija, C - trg, D - hierarhija) in dejavniki zadovoljstva (faktor I - vodenje, nagrajevanje in delovni pogoji, faktor 2 - sodelovanje in odnosi, faktor 3 - motiviranost za delo).

Hipotezo 4 , da obstaja statistično značilna povezanost med tipi organizacijske kulture in dejavniki zadovoljstva pri delu in z delovnimi razmerami, zavrnemo.

\section{Ugotovitve iz raziskave}

V raziskavi smo na vzorcu 166 zaposlenih v slovenskih gledališčih po metodologiji OCAI ugotavljali sedanji in želeni prevladujoči tip organizacijske kulture. Ugotavljali smo, ali je prevladujoči tip organizacijske kulture (sedanji) skladen pri večini dimenzij in ali obstajajo razlike $\mathrm{v}$ dojemanju organizacijske kulture med posameznimi organizacijskimi enotami, sektorji. Ugotavljali smo tudi statistično povezanost med tipi kulture in dejavniki zadovoljstva z delom in delovnimi razmerami. $S$ tem smo dosegli drugi cilj naše raziskave.

Ker organizacijska kultura v slovenskih gledališčih še ni bila raziskovana, smo se lahko oprli le na nekatere raziskave v drugih institucijah javnega sektorja (Kragelj 20ıо; Skinder Savić 2013; Bačovnik Komprej 20I4), ki so ugotovile prevlado kulture klana. Na tej osnovi smo postavili hipotezo, da v slovenskih gledališčih prevladuje organizacijska kultura tipa klan. Razlike $v$ povprečjih kažejo, da ne moremo potrditi hipoteze, da prevladuje organizacijska kultura tipa klan. Hipotezo smo zavrnili.

Povprečja, izračunana po metodologiji OCAI, kažejo, da zaposleni zaznavajo največ kulture tipa hierarhija (30,05 \%), ki si je v prihodnosti želijo bistveno manj ( $18,6 \%$ ), si pa zaposleni v prihodnosti močno želijo kulture klana $(36,5 \%)$.

Drugo hipotezo, da je organizacijska kultura skladna pri večini dimenzij, smo postavili na osnovi raziskav o skladnosti kulture (Prša 20ı; Lučič 20I4; Sršen 20I4), iz katerih smo razbrali, da tip kulture ni popolnoma skladen pri vseh dimenzijah, je pa skladen pri večini dimenzij.

Ugotovili smo, da lahko potrdimo hipotezo, da je tip organizacijske kulture skladen pri večini dimenzij. 
Tretjo hipotezo, da obstaja razlika v dojemanju organizacijske kulture med sektorji, smo postavili na osnovi raziskav, ki so ugotovile, da obstaja razkorak med dojemanjem organizacijske kulture med managerji in ostalimi zaposlenimi (Uršič Kern 2012; Otrin 2015) oziroma obstajajo razlike v dojemanju tipa organizacijske kulture med poklicnimi skupinami (Skinder Savić 2013) in tudi med različnimi poslovnimi enotami (Prša 2oı). Hipoteza, da obstaja razlika v dojemanju organizacijske kulture med sektorji, je bila zavrnjena. Sektorji nimajo pomembnega vpliva.

Ugotavljamo, da so zaposleni v slovenskih gledališčih srednje zadovoljni z delom in delovnimi razmerami $(3,29-$ na lestvici od I do 5$)$ in da ne obstaja statistično značilna povezanost med tipi organizacijske kulture (A - klan, B - adhokracija, C - trg, D - hierarhija) ter dejavniki zadovoljstva (faktor I - vodenje, nagrajevanje in delovni pogoji, faktor 2 - sodelovanje in odnosi, faktor 3 - motiviranost za delo).

\section{Predlogi za izboljšave}

Izidi raziskave kažejo, da sta $\mathrm{v}$ slovenskih gledaliških ustanovah najprisotnejši organizacijski kulturi tipa hierarhija in tipa trg, medtem ko si zaposleni v prihodnje kot skupno prevladujočo organizacijsko kulturo močno želijo organizacijsko kulturo tipa klan in manj prisotnosti zdaj prevladujočih tipov organizacijske kulture. Te ugotovitve terjajo razmislek o spreminjanju organizacijske kulture. Ustrezna organizacijska kultura namreč lahko bistveno pripomore $k$ povečanju uspešnosti organizacije, medtem ko ji neustrezna organizacijska kultura lahko škodi.

Prepričani smo, da bi sprememba organizacijske kulture prinesla koristi vsem zaposlenim $\mathrm{v}$ gledališčih. Izsledki naše raziskave bi lahko bili osnova za spreminjanje organizacijske kulture v gledaliških ustanovah. Priporočamo, da se pred spreminjanjem organizacijske kulture naredijo še dodatne analize v vsaki posamezni ustanovi (npr. z drugo metodo ali instrumentom, da bo možna primerjava izidov s sedanjo raziskavo) in da se na tej osnovi pripravi načrt spreminjanja za vsako ustanovo posebej. Pri sami izvedbi spreminjanja pa je pomembno, da se spremembe organizacijske kulture uvajajo postopoma in s soglasjem ter da se o njih sproti in jasno obvešča vse vpletene. Na ta način bo manj možnosti, da se bodo zaposleni upirali spremembam ali jih celo onemogočili.

Spreminjanje organizacijske kulture je možno npr. z zamenjavo simbolov, obredov in zgodb, z razbijanjem legend, rahljanjem subkultur (npr. $s$ kolobarjenjem sodelavcev in managerjev ter $\mathrm{z}$ načrtnim kadrovanjem) in s podpiranjem tistih sodelavcev, ki poosebljajo želene vrednote (Tavčar 2000, II 4 ). 
Ocenjujemo, da je prevladovanje organizacijske kulture tipa hierarhija posledica dejstva, da so gledališča del javnega sektorja, kjer so še vedno bolj kot inovativnost in podjetniška naravnanost pomembni sistem kontrole, zagotavljanje izvajanja formalnih pravil ter izpolnjevanje načrtovanih smotrov in ciljev, kjer vodenje temelji na zagotavljanju gladko tekoče učinkovitosti, ravnanje z zaposlenimi pa na varnosti zaposlitve in stabilnosti medsebojnih odnosov. Veljalo bi razmisliti o ukrepih za zmanjšanje nepotrebnih formalnih pravil, o večji podjetniški naravnanosti gledališč, o spodbujanju timskega dela in o zagotavljanju takšnih pogojev, ki bodo spodbujali inovativnost. Ukrepe za spodbujanje inovativnosti predlagamo predvsem na področjih delovnih procesov in ponudbe prijaznejših storitev za obiskovalce.

Vodenje ustanov naj temelji na vzgledu, mentorstvu, svetovanju in skrbi za zaposlene in naj bo podjetniško naravnano, manj usmerjeno zgolj $\mathrm{k}$ uresničevanju smotrov in ciljev organizacije.

Način vodenja naj temelji na timskem delu, iskanju soglasja in individualnem prevzemanju tveganja.

Ustanove naj poudarjajo vrednote, kot so razvoj zaposlenih, zaupanje, odprtost in sodelovanje. Manj naj poudarjajo tekmovalnost, dosežke, učinkovitost in kontrolo.

Ustanove naj bi pri svojem merilu uspeha uravnovesile zahteve financerjev po učinkovitosti in nizkih stroških delovanja ter želje zaposlenih, da bi njihove organizacije opredeljevale svoj uspeh na osnovi razvoja zaposlenih in skrbi zanje. Ocenjujemo, da je takšno ravnovesje mogoče doseči, saj se bodo z zmanjšanjem obremenjenosti zaposlenih zmanjšali tudi nekateri stroški v ustanovah.

Gledališče naj bi - kar je tudi želja zaposlenih - povezovali lojalnost, medsebojno zaupanje in predanost organizaciji (kultura klana), mnogo manj pa formalna pravila in sama politika organizacije (hierarhija). Ustanove naj ustvarijo tako vzdušje, kjer prevladuje zaupanje. Lojalnost in predanost zaposlenih organizaciji naj bi ustanove dosegle preko zadovoljstva zaposlenih.

Priporočamo, da se redno izvaja analize zadovoljstva zaposlenih z delom in delovnimi razmerami in da se izvede potrebne ukrepe za povečanje zadovoljstva zaposlenih. Gledališča naj bi z ustreznim kadrovskim načrtom vlagala v razvoj zaposlenih, $\mathrm{z}$ ustreznimi ukrepi izboljševala delovno okolje zaposlenih (tehnološko in prostorsko posodabljanje) ter zagotavljala sredstva za stimulacijo delovne uspešnosti zaposlenih in njihovo motiviranje. 


\section{Prispevek k znanosti}

Prispevek k znanosti, ki temelji na empirični raziskavi, je predvsem v tem, da gre za prvo raziskavo organizacijske kulture v gledališčih v Republiki Sloveniji. Najbistvenejše ugotovitve so, da organizacijska kultura ni enaka kot v drugih organizacijah, da je skladna, da ne obstaja razlika v dojemanju organizacijske kulture med organizacijskimi enotami (sektorji) in da tipi organizacijske kulture niso povezani z dejavniki zadovoljstva z delom in delovnimi razmerami. V empiričnem delu povzemamo spoznanja, ki so vezana na preučevane ustanove - gledališča nacionalnega pomena, ne izključujemo pa možnosti, da naša spoznanja v določeni meri veljajo tudi za vsa druga, manjša gledališča in druge ustanove. Na ta način smo prišli do novih spoznanj, ki v določeni meri spreminjajo dosedanja spoznanja. Ugotovili smo, da v slovenskih gledališčih (za razliko od izidov raziskav, na katere smo se oprli pri postavljanju hipotez) prevladuje organizacijska kultura tipa hierarhija, da različne organizacijske enote (sektorji) nimajo pomembnega vpliva na zaznani tip organizacijske kulture ter da dejavniki zadovoljstva $z$ delom in delovnimi razmerami niso povezani s tipi organizacijske kulture.

$\mathrm{Z}$ zasnovo predlogov za izboljšanje smo prispevali $\mathrm{k}$ managerski stroki in praksi na področju organizacijske kulture in zadovoljstva zaposlenih z delom in delovnimi razmerami. Pridobljeni rezultati, ugotovitve in sklepi so dobra osnova za preučitev sistematičnejšega pristopa $\mathrm{k}$ spreminjanju organizacijske kulture v gledališčih in bi bili lahko osnova pri oblikovanju organizacijske kulture ter $\mathrm{v}$ pomoč poslovodstvom gledališč pri spreminjanju in oblikovanju organizacijske kulture.

\section{Predlogi za nadaljnje raziskovanje}

Verjamemo, da smo z raziskavo prispevali pomemben kamenček v mozaik razumevanja organizacijske kulture $\mathrm{v}$ slovenskih gledaliških ustanovah. Za nadaljnje raziskovanje predlagamo predvsem naslednje metodološke in vsebinske usmeritve:

- redno izvajanje raziskav in analiz organizacijske kulture v gledališčih,

- uporaba druge metodologije zbiranja in analiziranja podatkov ter informacij o organizacijski kulturi v obravnavanih ustanovah,

- primerjava izidov posameznih raziskav in evalvacija napredka oziroma sprememb, 
- izvedba raziskave po posameznih slovenskih gledališčih, ki bi omogočila primerjavo med samimi gledališči,

- redno izvajanje raziskav in analiz zadovoljstva zaposlenih z delom ter delovnimi razmerami,

- izvedba raziskave o organizacijski kulturi v tujih/sosednjih državah in primerjava rezultatov,

- primerjalna raziskava organizacijske kulture v zasebnih in državnih gledališčih,

- raziskava vpliva organizacijske kulture na druge finančne in nefinančne kazalnike uspešnosti,

- večje število anketiranih,

- uporaba drugega instrumenta, npr. izvedba intervjuja ipd.,

- uporaba kvalitativne metodologije in primerjava dobljenih rezultatov.

\section{Literatura}

AJPES (Agencija Republike Slovenije za javnopravne evidence in storitve). B. l. Vstopna stran. Dostop 30. marca 2016. http://www.ajpes.si/.

Cameron, K. S., in R. E. Quinn. 2006. Diagnosing and Changing Organizational Culture. San Francisco: Jossey Bass A Wiley Imprint.

Easterby-Smith, M., R. Thorpe in A. Lowe. 2007. Raziskovanje v managementu. Koper: Univerza na Primorskem, Fakulteta za management.

Flere, S. 2000. Sociološka metodologija: temelji družboslovnega raziskovanja. Maribor: Univerza v Mariboru, Pedagoška fakulteta.

Kragelj, J. 2010. Organizacijska kultura zaposlenih v zdravstveni negi v bolniśnici. Magistrska naloga, Koper: Univerza na Primorskem, Fakulteta za management.

Statistični urad Republike Slovenije. B. 1. Vstopna stran. Dostp I. marca 2016. http://pxweb.stat.si/.

Tavčar, M. I. 2000. Kulture, etika in olika managementa. Kranj: Moderna organizacija.

Zakrajšek, T., in S. Žuntar. 2012/2013. »Izbrani vprašalniki za uporabo na področju psihologije dela in organizacije: Organizacijska kultura.« https://psihologijadela.files. wordpress.com /2014/03/organizacijska-kulturai.pdf. 


\title{
Organizacijska kultura
}

in finančna dodana vrednost

v tujih podjetjih v Sloveniji

\author{
Benjamin Kmetec in Mirko Markič
}

V zadnjem desetletju se v podjetjih in drugih organizacijah soočajo z novimi izzivi pri zagotavljanju sedanje in prihodnje uspešnosti. Poleg nevarnosti, ki jih prinaša globalna konkurenčnost, se pojavljajo tudi številne nove priložnosti (Whitelock 2002, 344). V tistih podjetjih, ki jih želijo izkoristiti v svojo korist, naj bi se nenehno spreminjali v skladu s spremembami v družbenem in poslovnem okolju oziroma spremembe tudi povzročali (Hrastelj 1990, 422). V tej globalni konkurenčnosti ima organizacijska kultura $\mathrm{z}$ zakoreninjeno temeljno osnovo v nenapisanih $\gg$ pravilih igre « ali temeljnih predpostavkah na nezavedni ravni zelo velik pomen (Schein 1997, 17). Prav zaradi navedenega imajo kulturološki in organizacijski dejavniki čedalje večji vpliv na poslovanje podjetij v modernem in globaliziranem mednarodnem poslovnem okolju.

Kultura v organizaciji nastaja kot posledica skupinskega življenja. Skupna pot razreševanja problemov, iskanja odgovorov na številna vprašanja organizacijskega delovanja ustvarja zgodovino organizacije in oblikuje njeno kulturo (Mesner-Andolšek 1995, 132). Organizacijska kultura je v organizacijski teoriji relativno mlad pojem. Kot teoretični pojem se je začel uveljavljati šele od 70 . letih prejšnjega stoletja najprej. V realnosti pa se je pomembnost tega pojava pokazala že, ko so Japonci pričeli s svojim gospodarskim čudežem. Američani so začeli iskati vzvode zanj, vendar ne tehnološka prednost, znanje, kapital ali optimiranje logistike niso dali zadovoljivega odgovora na japonski čudež. Šele po natančnem preučevanju japonskih organizacij so odkrili vrsto posebnosti v organizacijskih strukturah in združbah kot celotah (Kavčič 2005, 4). Organizacijska kultura je prisotna v vseh družbah. Razvojnim zamislim daje zalet ali pa 
jih zatre že v kali. V mnogih organizacijah sistemske spremembe potekajo več let, najmanj od tri do pet. Glavni razlogi za tako dolgotrajne sistemske spremembe so kompleksnost in nejasnost organizacijske kulture ter močan vpliv organizacijske kulture na spremembe v organizacijah (Alvesson in Sveningsson 2008).

Glede na (bodisi ugoden bodisi neugoden) vpliv organizacijske kulture na uspešnost organizacije velja omeniti velik pomen oblikovanja močne organizacijske kulture. Kot trdita Kotter in Heskett (1992, IOI2), ima organizacija izoblikovano močno organizacijsko kulturo takrat, ko govorimo o skladnosti metod dela in vrednosti pri vseh managerjih ob hkratni visoki stopnji sprejemanja oziroma poistovetenja zaposlenih z vrednotami.

Dodano vrednost je mogoče izračunati za izdelovalna in tudi za storitvena podjetja. Podjetniško uspešnost nam kaže informacija o tem, koliko enot proizvoda odpade na enega zaposlenega v določeni časovni enoti. Govorimo o dodani vrednosti na zaposlenega (DVZ). DVZ je ključni kazalnik kakovosti poslovanja $\mathrm{v}$ podjetju ali drugi organizaciji, njegove organiziranosti, tehnološke strukture in managementa (Pečnik 2008, 33):

- merila donosnosti (EPS - Earnings per Share; ROI - Return on Investment; ROA - Return on Assets; ROE - Return on Equity; ROCE - Return On Capital Employed),

- merila denarnega toka (DCF - Discounted Cash Flow; ROGI - Return on Gross Investment; CFROI - Cash-Flow Return on Investment),

- merila vrednosti (EVA - Economic Value Added; MVA - Market Value Added; CVA - Cash Value Added; SVA - Shareholder Value Added).

\section{Namen raziskave}

Namen raziskave je ugotoviti, kakšna je prevladujoča organizacijska kultura $\mathrm{v}$ tujih podjetjih $\mathrm{v}$ Sloveniji in kakšna usmerjenost $\mathrm{k}$ posameznim kulturam se kaže na različnih ravneh organiziranosti, ter podati predloge za izboljšanje.

\section{Opredelitev vzorca in potek raziskave}

Vzorec raziskave zajema mikro, mala, srednje velika in velika (ZGD-I, Uradni list $R S$ št. 42/2006) slovenska podjetja s tujim kapitalom s peti$\mathrm{mi}$ ali več zaposlenimi. Kriteriji za omejitev izbranih podjetij iz podatkovne baze Bizi.si so bili: lastništvo tujega kapitala; letni promet, večji 
od 520.000 EUR; število zaposlenih; pravni status (d. d., d. o. o., d. n. o., k. d.). Po teh kriterijih je bilo izbranih 437 podjetij v Republiki Sloveniji. Pričakovali smo 25-40-odstotno stopnjo odgovorov (Flere 2000, I8). Stopnja odgovora po zaključenem anketiranju je bila $47 \%$ (od 237 klikov na anketo je bilo v celoti izpolnjenih I 13 anketnih vprašalnikov). Če opredelimo odzivnost glede na povprečno število zaposlenih tujih notranjih povezanih podjetij (SURS 2010), je ta veliko manjša.

Glavno oviro pri našem delu je predstavljala neodzivnost posameznikov, ki so zaposleni v tujih podjetjih, saj smo odgovore zbirali slabih deset mesecev. Na koncu smo dobili i I $3 \mathrm{v}$ celoti izpolnjenih anket, ki so bile primerne za obdelavo podatkov.

\section{Vprašalnik}

Za potrebe empiričnega dela magistrske naloge smo uporabili tipologijo po Cameronu in Quinnu (1999), tako imenovani OCAI-vprašalnik, $\gg$ The Competing Values Framework - CVF « (model konkurenčnih vrednot). Cameron in Quinn sta na podlagi merskega inštrumenta določila štiri glavne tipe organizacijskih kultur.

Vprašalnik smo izbrali, ker meri različne dimenzije organizacijske kulture. Omogoča hkraten prikaz dejanskega in želenega stanja organizacijske kulture v podjetju. $\mathrm{V}$ vprašalniku smo uporabili zaprta in odprta vprašanja. Na koncu smo dodali tudi nekaj demografskih vprašanj (glej prilogo I).

Vprašalnik meri naslednje dimenzije:

- splošne karakteristike podjetja,

- vodenje v organizaciji,

- sistem ravnanja z zaposlenimi,

- lepilo organizacije,

- strateške poudarke,

- kriterije uspeha.

Vsak izmed šestih sklopov vsebuje štiri trditve, ki merijo točno določen tip organizacijske kulture. Tipi so za lažjo prepoznavo in obdelavo označeni s črkami. Črka A predstavlja kulturo klana, črka B ad hoc kulturo, črka C kulturo trga, črka D pa kulturo hierarhije.

Izpolnjevanje vprašalnika poteka tako, da je pri vsakem izmed šestih sklopov anketirani med štiri izbrane trditve posameznega sklopa razdelil Ioo točk, in sicer po principu največ točk trditvi, ki najbolje opisuje dejansko stanje, dokler se ni vseh roo točk porazdelilo med vse štiri trdi- 
tve posameznega sklopa. Postopek se je ponovil še za trditve, ki opisujejo želeno stanje.

\section{Zbiranje podatkov}

Izmed različnih metod zbiranja podatkov smo se odločili za spletno zbiranje podatkov (Web Survey), ki je v primerjavi z drugimi načini anketiranja hitreje izvedljivo in omogoča dostop do vprašalnika kjer koli in kadar koli. Je tudi cenejši način zbiranja podatkov in omogoča nadzor nad posameznim odgovorom.

Podjetja, na katera smo se obrnili s prošnjo reševanja ankete, smo zbrali tako, da smo posameznim podjetjem, ki so ustrezala našim izbranim karakteristikam, po elektronski pošti poslali povabilo k izpolnitvi vprašalnika $z$ razlago in namenom anketiranja ter povezavo do spletnega vprašalnika. Zaradi omejenega odziva smo osebno poklicali v podjetja in jih povabili k sodelovanju. Anketiranje je bilo s pomočjo programskega orodja FluidSurveys.si izvedeno v času od oktobra 2010 do avgusta 20I I. Nekaj anketnih vprašalnikov smo zaradi neznanja uporabe interneta posredovali v fizični obliki ter jih nato vnesli v programsko orodje FluidSurvey.si, da smo podatke nadalje lažje statistično obdelovali.

Podatke za statistično obdelavo in določanje uspešnosti podjetij smo napravili na podlagi podatkovne baze Bizi. Podatke analiziranih podjetij smo za vsako podjetje posebej izpisovali v Excelovo podatkovno preglednico in na tak način prišli do izidov raziskovalnega vzorca. Uspešnost podjetja smo enačili na podlagi računovodskega podatka poslovnega izida.

\section{Obdelava podatkov}

V kvantitativnem delu empirične študije smo zbrane primarne podatke statistično obdelali s programskim paketom SPSS (Statistical Package for the Social Sciences). Podrobnejša analiza postavk vprašalnika je opisana v poglavju Izidi raziskave. Podatke, ki smo jih pridobili s pomočjo spletne ankete, smo opisno (deskriptivno) analizirali. To pomeni, da smo za intervalne spremenljivke izračunali povprečno oceno $(\mathrm{M})$ in standardni odklon (SD).

Preden smo se lahko lotili analiz podatkov, smo morali podatke ustrezno pripraviti. Ker so udeleženci raziskave med štiri trditve posameznega sklopa razdelili soo točk, smo želeli ugotoviti, koliko točk so anketirani pripisali posamezni trditvi in posledično posameznemu tipu organizacijske kulture. 


\section{Izidi raziskave}

Poglavje Izidi raziskave je razdeljeno na več delov. Na začetku poglavja bomo predstavili dejansko kulturo $\mathrm{v}$ podjetjih, $\mathrm{v}$ katerih so anketirani zaposleni. Sledi predstavitev želene kulture ter primerjava med dejansko in želeno kulturo. Izide bomo prikazali tudi po posameznih sklopih in glede na spol, starost, zaposlitveno dobo, tip zaposlitve ter delovno mesto, ki ga zasedajo anketirani. Sledili bosta korelacijska analiza, kjer bomo predstavili povezanost med posameznimi tipi organizacijske kulture, ter faktorska analiza, s pomočjo katere bomo ugotavljali, s koliko skupnimi faktorji lahko predstavimo organizacijsko kulturo in kateremu področju organizacijske kulture dajejo anketirani največ poudarka. S pomočjo regresijske analize bomo preverjali vpliv različnih vidikov (spol, starost itd.) na organizacijsko kulturo. Tik pred koncem poglavja bomo predstavili še preverjanje hipotez.

\section{Normalnost porazdelitve}

Pred analizo izvedenih spremenljivk smo preverili, ali so spremenljivke, ki jih bomo uporabili, normalno porazdeljene (glej preglednico 9.I: Test normalne porazdelitve). Ugotavljamo, da sta izvedeni spremenljivki kultura klana in ad hoc kultura normalno porazdeljeni. Pravimo, da so spremenljivke normalno porazdeljene, ko so porazdeljene po Gaussovi krivulji. Kadar temu ni tako, pravimo, da spremenljivke niso normalno porazdeljene. Spremenljivki kultura trga in kultura hierarhije nista normalno porazdeljeni.

Preglednica 9.1: Test normalne porazdelitve

\begin{tabular}{|c|c|c|c|}
\hline & \multicolumn{2}{|c|}{ Kolmogorov-Smirnov(a) } & \multirow{2}{*}{ Stopnja značilnosti } \\
\hline & Statistika & Stopnja prostosti & \\
\hline Kultura klana & $0,07 \mathrm{I}$ & II3 & 0,200 \\
\hline Ad hoc kultura & 0,097 & $\mathrm{II} 3$ & ०,OII \\
\hline Kultura trga & 0,134 & $\mathrm{II} 3$ & 0,000 \\
\hline Kultura hierarhije & 0,106 & II3 & 0,003 \\
\hline
\end{tabular}

\section{Analiza strukture vzorca}

V raziskavi je sodelovalo II 3 anketiranih. Od tega 43 ( $38 \%)$ moških in $70(62 \%)$ žensk. Povprečna starost anketiranih je 36 let. Anketirani so v podjetju v povprečju zaposleni sedem let in imajo redno obliko zaposlitve $(84 \%)$. 


\begin{tabular}{|c|c|c|c|}
\hline & & $\mathbf{N}$ & $\operatorname{Delež}(\%)$ \\
\hline \multirow{2}{*}{ Spol } & Ženski & 70 & 61,9 \\
\hline & Moški & 43 & $38, \mathrm{I}$ \\
\hline \multirow{4}{*}{ Starost } & $20-29$ & 24 & 21,2 \\
\hline & $30-39$ & 56 & 49,6 \\
\hline & $40-49$ & 25 & $22, \mathrm{I}$ \\
\hline & $50+$ & 8 & 7,1 \\
\hline \multirow{5}{*}{ Področje dela } & Spodnji management & 8 & 7,1 \\
\hline & Srednji management & $2 \mathrm{I}$ & 18,6 \\
\hline & Strokovnjak & 15 & 13,3 \\
\hline & Vršni management & 15 & 13,3 \\
\hline & Zaposleni & 54 & 47,8 \\
\hline \multirow{3}{*}{$\mathrm{V}$ podjetju ste zaposleni } & Redno & 95 & $84, \mathrm{I}$ \\
\hline & $\begin{array}{l}\text { Preko študentske na- } \\
\text { potnice }\end{array}$ & 6 & 5,3 \\
\hline & Druge oblike zaposlitve & 12 & 10,6 \\
\hline
\end{tabular}

Preglednica 9.3: Demografska struktura vzorca 2

\begin{tabular}{lccccc} 
& N & M & Me & Mo & SD \\
Delovna doba & I13 & 6,9 & 5,0 & 5 & 6,5 \\
\hline Starost & I13 & 35,9 & 34,0 & 34 & 8, I \\
\hline
\end{tabular}

Polovica anketiranih je starih med 30 in 39 let. Dobra petina jih je starih med 20 in 29 let $(2 \mathrm{I} \%)$ in prav tako dobra petina med 40 in 49 let. $7 \%$ anketiranih je starih 50 let ali več.

Slaba polovica (48 \%) je v podjetju zaposlenih, I9 \% je zaposlenih na položaju srednji management, po $13 \%$ je zaposlenih v vršnem managementu in na položaju strokovnjaka, 7 \% pa na položaju spodnjega managementa. Večina je redno zaposlena, $5 \%$ je zaposlenih preko študentske napotnice, Io \% pa ima kakšno drugo obliko zaposlitve (pogodba za določen čas itd.).

\section{Dejansko stanje}

Preden se lotimo razlage rezultatov, na hitro predstavimo, kaj nam posamezen tip organizacijske kulture vsebinsko predstavlja. Po tipologiji Camerona in Quinna (1999, 30-33) ločimo štiri različne dimenzije (ek- 
stravertiranost, introvertiranost, stabilnost in fleksibilnost), na podlagi katerih določamo štiri različne tipe organizacijskih kultur (prav tam, 33-38):

- Kultura klana je dobila ime zaradi podobnosti družinskemu tipu organizacije.

- Ad hoc kultura je ena najodzivnejših organizacijskih kultur v turbulentnem družbenem oziroma poslovnem okolju 2r. stoletja. Osnovne predpostavke te kulture so se razvijale na popolnoma drugačen način od preostalih opisanih tipov kultur in temeljijo na inovativnosti: biti prvi v razvoju neke razrešitve, kajti to je tisto, kar vodi k uspehu.

- Kultura trga je zelo priljubljena postala v poznih šestdesetih letih 2o. stoletja, ko so se začeli v podjetjih soočati z novimi konkurenčnimi izzivi.

- Kultura hierarbije; do šestdesetih let 20. stoletja je skoraj vsaka knjiga o študiju managementa in organizacije temeljila na Webrovi predpostavki hierarhije oziroma birokracije kot idealni obliki organizacije, ki je omogočila stabilne, učinkovite in visokokakovostne izdelke ter storitve.

Zanimalo nas je, katera je prevladujoča organizacijska kultura v podjetjih, kjer so anketirani zaposleni. Anketirani so morali med vse tipe organizacijskih kultur razdeliti Ioo točk. Če so vse organizacijske kulture ovrednotili enako, so vsaki izmed njih dodelili 25 točk. Vsaka organizacijska kultura, ki so ji anketirani dodelili več kot 25 točk, predstavlja morebitno prevladujočo organizacijsko kulturo. $S$ pomočjo t-testa (glej prilogo 4, tabela I), smo preverili, ali se vrednost indeksa organizacijskih kultur razlikuje od 25 točk in na ta način še statistično preverili prevladujočo organizacijsko kulturo.

V preglednici 9.4 so prikazani rezultati dejanske organizacijske kulture. Vidimo, da sta s po 27 točkami prevladujoči kulturi tipa kultura trga in kultura hierarhije - razlika med številom točk, ki je bil dodeljen tipu kulture ( 27 točk), in testno vrednostjo ( 25 točk) - pomembni pri stopnji tveganja io \%. T-test nam tudi pove, da je tip kulture ad hoc kultura manj zaznan kot prevladujoč tip kulture v podjetjih, kjer so anketirani zaposleni (2I točk). 
Organizacijska kultura in organizacijska klima

Preglednica 9.4: Deskriptivni podatki o dejanskem stanju organizacijske kulture

\begin{tabular}{lccccc} 
& N & M & SD & Minimum & Maksimum \\
\hline Kultura klana & I17 & 25 & I2 & 0 & 67 \\
\hline Ad hoc kultura & I17 & 21 & 8 & 0 & 53 \\
\hline Kultura trga & I17 & 27 & 13 & 0 & 71 \\
\hline Kultura hierarhije & 117 & 27 & II & $\circ$ & 75 \\
\hline
\end{tabular}

Preglednica 9.5: Deskriptivni podatki o dejanskem stanju organizacijske kulture

\begin{tabular}{|c|c|c|c|c|c|c|}
\hline & & $\mathbf{N}$ & $\mathbf{M}$ & SD & Minimum & Maksimum \\
\hline \multirow{4}{*}{$\begin{array}{l}\text { Splošne karakteris- } \\
\text { tike podjetja }\end{array}$} & Kultura klana & 113 & 20 & 16 & $\circ$ & 100 \\
\hline & Ad hoc kultura & 113 & 26 & 16 & $\circ$ & 100 \\
\hline & Kultura trga & 113 & 27 & 15 & $\circ$ & 80 \\
\hline & Kultura hierarhije & 113 & 26 & 20 & $\circ$ & 100 \\
\hline \multirow{4}{*}{$\begin{array}{l}\text { Vodenje v organi- } \\
\text { zaciji }\end{array}$} & Kultura klana & 113 & 23 & 16 & $\circ$ & 100 \\
\hline & Ad hoc kultura & 113 & 20 & 12 & $\circ$ & 50 \\
\hline & Kultura trga & 113 & 29 & 21 & $\circ$ & 100 \\
\hline & Kultura hierarhije & $\mathrm{II} 3$ & 28 & 17 & $\circ$ & 100 \\
\hline \multirow{4}{*}{$\begin{array}{l}\text { Sistem ravnanja z } \\
\text { zaposlenimi }\end{array}$} & Kultura klana & 113 & 28 & 19 & $\circ$ & 100 \\
\hline & Ad hoc kultura & 113 & 20 & 15 & $\circ$ & 100 \\
\hline & Kultura trga & 113 & 28 & 23 & $\circ$ & 100 \\
\hline & Kultura hierarhije & 113 & 23 & 16 & $\circ$ & 100 \\
\hline \multirow{4}{*}{ Lepilo organizacije } & Kultura klana & 113 & 28 & 19 & $\circ$ & 100 \\
\hline & Ad hoc kultura & II3 & 24 & 14 & $\circ$ & 60 \\
\hline & Kultura trga & 113 & 23 & 19 & $\circ$ & 100 \\
\hline & Kultura hierarhije & 113 & 24 & 17 & $\circ$ & 100 \\
\hline \multirow{4}{*}{ Strateški poudarki } & Kultura klana & II3 & 23 & 15 & $\circ$ & 70 \\
\hline & Ad hoc kultura & II3 & 23 & I5 & $\circ$ & 100 \\
\hline & Kultura trga & 113 & 27 & 20 & $\circ$ & 100 \\
\hline & Kultura hierarhije & 113 & 27 & I8 & $\circ$ & 100 \\
\hline \multirow{4}{*}{ Kriteriji uspeha } & Kultura klana & 113 & 24 & I8 & $\circ$ & 80 \\
\hline & Ad hoc kultura & 113 & 15 & II & $\circ$ & 50 \\
\hline & Kultura trga & 113 & 28 & I8 & ० & 100 \\
\hline & Kultura hierarhije & II3 & 32 & 22 & $\circ$ & 100 \\
\hline
\end{tabular}


V poglavju Izhodišča raziskave smo omenili, da je uporabljeni merski inštrument sestavljen iz šestih sklopov (splošne karakteristike podjetja, vodenje $\mathrm{v}$ organizaciji, sistem ravnanja z zaposlenimi, lepilo organizacije, strateški poudarki, kriteriji uspeha). Poglejmo, katero organizacijsko kulturo anketirani občutijo kot prevladujočo v podjetjih, kjer so zaposleni, glede na posamezni tematski sklop. V prvem sklopu, splošne karakteristike podjetja, prevladuje kultura trga ( 27 točk), sledita ad hoc kultura in kultura hierarhije s po 26 točkami; z 20 točkami je na zadnjem mestu kultura klana. V drugem sklopu, vodenje $\mathrm{v}$ organizaciji, je prevladujoča kultura trga (29 točk), sledijo kultura hierarhije ( 28 točk), kultura klana (23 točk) in ad hoc kultura (20 točk). V tretjem sklopu, sistem ravnanja z zaposlenimi, anketirani kot prevladujočo kulturo zaznajo kulturo klana (29 točk), sledijo kultura trga (27 točk), kultura hierarhije ( 23 točk) in ad hoc kultura (2o točk). V četrtem sklopu, lepilo organizacije, prevladuje kultura klana ( 28 točk), sledijo kultura hierarhije (24 točk), ad hoc kultura ( 24 točk) in kultura trga ( 23 točk). V petem sklopu, strateški poudar$\mathrm{ki}$, prevladujeta dve kulturi - trga in hierarhije ( 27 točk), sledita kultura klana in ad hoc kultura s po 23 točkami. V zadnjem, šestem sklopu, kriterij uspeha, anketirani kot prevladujočo organizacijsko kulturo $\mathrm{v}$ podjetjih, kjer so zaposleni, zaznavajo kulturo hierarhije ( 32 točk), sledijo kultura trga ( 28 točk), kultura klana ( 24 točk) in ad hoc kultura (Is točk).

Vsaka organizacijska kultura, ki so ji anketirani dodelili več kot 25 točk, predstavlja morebitno organizacijsko kulturo, ki si jo anketirani želijo v podjetjih, v katerih so zaposleni. S pomočjo t-testa smo preverili, ali se vrednost indeksa organizacijskih kultur razlikuje od 25 točk, in na ta način še statistično preverili prevladujočo organizacijsko kulturo po posameznih sklopih.

Ugotovili smo, da je v prvem (splošne karakteristike podjetja s 27 točkami) in v drugem sklopu (vodenje v organizaciji z 29 točkami) prevladujoča kultura tipa kultura trga. $V$ tretjem sklopu, sistem ravnanja z zaposlenimi, in v četrtem sklopu, lepilo organizacije, z 28 točkami prevladuje kultura klana. V šestem sklopu, kriterij uspeha, anketirani kot prevladujočo organizacijsko kulturo v podjetju, kjer so zaposleni, izpostavljajo kulturo hierarhije ( 32 točk). T-test (glej prilogo 4, tabela 2) potrdi, da so razlike med številom točk in testno vrednostjo pomembne. $V$ petem sklopu, strateški poudarki, prevladujeta dve kulturi - trga in hierarhije (27 točk), vendar razlike niso pomembne, tako da ne moremo reči, da anketirani ti dve kulturi vidijo kot prevladujoči. Ravni tveganja za takšno zaključevanje so med o in ro \% tveganja oziroma kot je navedeno pri stopnji značilnosti. 


\section{Želeno stanje}

V tem poglavju predstavljamo rezultate želene organizacijske kulture anketiranih $\mathrm{v}$ podjetjih, $\mathrm{v}$ katerih so zaposleni.

Zanimalo nas je, kateri tip kulture si anketirani v podjetjih, kjer so zaposleni, želijo v prihodnje. Dodatno nas je zanimalo, ali se želena organizacijska kultura razlikuje glede na posamezen sklop vprašalnika. Anketirani so morali tudi v tem delu vprašalnika med vse tipe organizacijskih kultur razdeliti roo točk. Če so vse organizacijske kulture ovrednotili enako, so jim dodelili 25 točk. Vsaka organizacijska kultura, ki so ji anketirani dodelili več kot 25 točk, predstavlja morebitno prevladujočo organizacijsko kulturo. $S$ pomočjo t-testa smo preverili, ali se vrednost indeksa organizacijskih kultur razlikuje od 25 točk, in na ta način še statistično preverili prevladujočo organizacijsko kulturo.

Iz preglednice 9.6 je razvidno, da si anketirani v podjetjih, kjer so zaposleni, v prihodnosti želijo kulture klana ( 37 točk). Sledijo ad hoc kultura ( 26 točk), kultura hierarhije ( 2 točk) in kultura trga ( 17 točk). T-test potrdi, da so pri tipu kulture klana, trga in hierarhije razlike med številom točk in testno vrednostjo ( 25 točk) pomembne. Anketirani si v podjetjih, kjer so zaposleni, želijo kulture klana.

Preglednica 9.6: Deskriptivni podatki o želenem stanju organizacijske kulture

\begin{tabular}{lccccc} 
& N & M & SD & Minimum & Maksimum \\
Kultura klana & 117 & 37 & 12 & 10 & 75 \\
\hline Ad hoc kultura & 117 & 26 & 7 & 10 & 50 \\
\hline Kultura trga & 117 & 17 & 8 & 0 & 43 \\
\hline Kultura hierarhije & 117 & 21 & 9 & 0 & 70 \\
\hline
\end{tabular}

Tudi tukaj je bil uporabljeni merski inštrument sestavljen iz šestih sklopov (splošne karakteristike podjetja, vodenje v organizaciji, sistem ravnanja z zaposlenimi, lepilo organizacije, strateški poudarki, kriteriji uspeha). Poglejmo rezultate o želeni organizacijski kulturi po posameznih sklopih.

Iz preglednice 9.7 je razvidno, da je $\mathrm{v} v$ seh sklopih prevladujoča organizacijska kultura klana. $V$ prvem sklopu, splošne karakteristike podjetja, s 35 točkami, v drugem sklopu, vodenje v organizaciji, s 34 točkami, $\mathrm{v}$ tretjem sklopu, sistem ravnanja z zaposlenimi, z 38 točkami, $\mathrm{v}$ četrtem sklopu, lepilo organizacije, s 37 točkami, v petem sklopu, strateški poudarki, s 35 točkami, in v šestem sklopu, kriterij uspeha, z 39 točkami. Anketirani si v podjetjih, kjer so zaposleni, želijo organizacijsko kulturo kla- 
na. T-test potrdi (glej prilogo 4, tabela 3), da je razlika med številom točk pri indeksu kultura klana in testno vrednostjo ( 25 točk) pomembna za vseh šest sklopov.

Anketirani si v podjetjih, kjer so zaposleni, v prihodnosti želijo organizacijsko kulturo, ki je podobna družinskemu tipu organizacije. Ta tendenca morebiti izhaja iz dejstva, da so takšne organizacije usmerjene navznoter in se v njih goji skrben odnos do zaposlenih. Vodje $v$ takšnih organizacijah igrajo predvsem vlogo mentorja; včasih je ta odnos tudi starševski, kar zaposlenim nudi psihološko varnost. Prav tako je poudarek na složnosti in vzdušju, osebni razvoj posameznika stoji na prvem mestu. Kultura klana se odraža tudi v složnosti, timskem delu, soglasju, kar skupaj privede do harmonizacije okolja, kakršnega si zaposleni po naravnem vzgibu najbolj želijo.

Preglednica 9.7: Deskriptivni podatki o želenem stanju organizacijske kulture po sklopih

\begin{tabular}{|c|c|c|c|c|c|c|}
\hline & & $\mathbf{N}$ & $\mathbf{M}$ & SD & Minimum & Maksimum \\
\hline \multirow{4}{*}{$\begin{array}{l}\text { Splošne karakteris- } \\
\text { tike podjetja }\end{array}$} & Kultura klana & $\mathrm{II3}$ & 35 & $2 \mathrm{I}$ & $\circ$ & 100 \\
\hline & Ad hoc kultura & I13 & 27 & 17 & $\circ$ & 100 \\
\hline & Kultura trga & $\mathrm{I13}$ & 20 & II & $\circ$ & 50 \\
\hline & Kultura hierarhije & 113 & 18 & 14 & $\circ$ & 70 \\
\hline \multirow{4}{*}{$\begin{array}{l}\text { Vodenje v orga- } \\
\text { nizaciji }\end{array}$} & Kultura klana & 113 & 34 & 16 & $\circ$ & 100 \\
\hline & Ad hoc kultura & 113 & 26 & 15 & $\circ$ & 100 \\
\hline & Kultura trga & $\mathrm{II3}$ & 16 & 10 & $\circ$ & 50 \\
\hline & Kultura hierarhije & $\mathrm{II} 3$ & 25 & 13 & $\circ$ & 70 \\
\hline \multirow{4}{*}{$\begin{array}{l}\text { Sistem ravnanja z } \\
\text { zaposlenimi }\end{array}$} & Kultura klana & 113 & 38 & 16 & 10 & 100 \\
\hline & Ad hoc kultura & $\mathrm{II3}$ & 24 & 12 & $\circ$ & 70 \\
\hline & Kultura trga & $\mathrm{II} 3$ & 15 & 10 & $\circ$ & 50 \\
\hline & Kultura hierarhije & 113 & 22 & 14 & $\circ$ & 70 \\
\hline \multirow{4}{*}{ Lepilo organizacije } & Kultura klana & I13 & 37 & 17 & IO & 100 \\
\hline & Ad hoc kultura & 113 & 27 & 12 & $\circ$ & 50 \\
\hline & Kultura trga & 113 & 16 & II & $\circ$ & 50 \\
\hline & Kultura hierarhije & 113 & 20 & 12 & $\circ$ & 70 \\
\hline \multirow{4}{*}{ Strateški poudarki } & Kultura klana & $\mathrm{II} 3$ & 35 & I5 & $\circ$ & 80 \\
\hline & Ad hoc kultura & 113 & 28 & I5 & $\circ$ & 100 \\
\hline & Kultura trga & 113 & 17 & 12 & $\circ$ & 100 \\
\hline & Kultura hierarhije & $\mathrm{II} 3$ & 20 & 13 & $\circ$ & 70 \\
\hline
\end{tabular}




\begin{tabular}{|c|c|c|c|c|c|c|}
\hline & & $\mathbf{N}$ & M & SD & Minimum & Maksimum \\
\hline \multirow{4}{*}{ Kriteriji uspeha } & Kultura klana & 113 & 39 & 18 & $\circ$ & 100 \\
\hline & Ad hoc kultura & $\mathrm{II} 3$ & 21 & 13 & $\circ$ & 70 \\
\hline & Kultura trga & 113 & 18 & 12 & $\circ$ & 60 \\
\hline & Kultura hierarhije & 113 & 22 & 16 & $\circ$ & 100 \\
\hline
\end{tabular}

\section{Razlike}

V tem poglavju predstavljamo razlike med dejansko in želeno organizacijsko kulturo v podjetjih, kjer so anketirani zaposleni.

V predhodnih poglavjih smo omenili, da anketirani kot prevladujočo organizacijsko kulturo v podjetjih, kjer so zaposleni, občutijo kulturo hierarhije ( 27 točk) in kulturo trga ( 27 točk). Sledita kultura klana (25 točk) in ad hoc kultura (2 I točk). Anketirani si v podjetjih, kjer so zaposleni, želijo kulture klana ( 37 točk), sledi ad hoc kultura ( 26 točk), kultura hierarhije (2 I točk) in kultura trga ( 17 točk).

Splošne želje, vrednote, ki se odražajo v kulturi organizacije, v kateri želijo zaposleni delati, so odvisne od položaja, osebnih interesov in socialno-družbene percepcije posameznika.

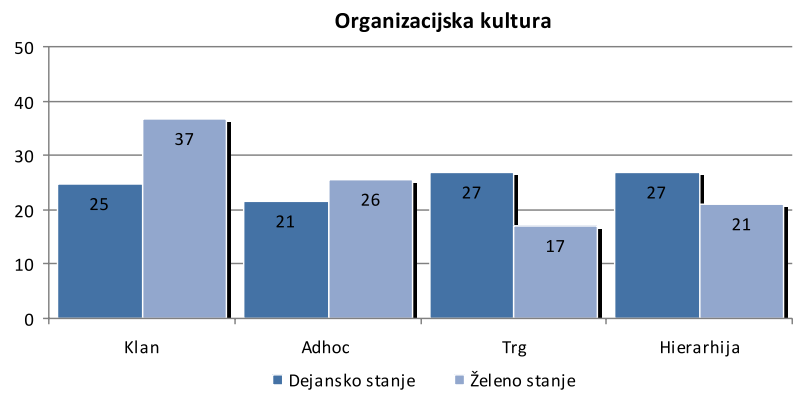

Slika 9.I: Vrednosti spremenljivk posameznega tipa organizacijske kulture

V predhodnih poglavjih smo predstavili deskriptivne podatke za spremenljivke, ki merijo dejansko in želeno stanje organizacijske kulture v podjetjih. Statistično pomembnost razlik med dejanskim in želenim stanjem organizacijske kulture smo preverili s pomočjo t-testa. Primerjali smo pare spremenljivk, ki merijo dejansko in želeno stanje. Preverili smo, ali med posameznimi pari spremenljivk obstaja korelacija. Med pari spremenljivk zaznamo šibke korelacije. Razvidno je, da so razlike med dejanskim in želenim stanjem statistično pomembne, kar nakazuje stopnja značilnosti, ki je pri vseh štirih parih spremenljivk manjša od o,05. S t-te- 
stom smo potrdili, da obstajajo razlike med percepcijo dejanske organizacijske kulture in želeno organizacijsko kulturo v podjetjih, kjer so anketirani zaposleni.

Preglednica 9.8: Deskriptivni podatki o želenem stanju organizacijske kulture po sklopih

\begin{tabular}{lllll} 
& & N & Korelacija & Stopnja značilnosti \\
Par A - kultura klana & Dejansko stanje - Želeno stanje & $\mathrm{II3}$ & 0,174 & 0,065 \\
\hline Par B - ad hoc kultura & Dejansko stanje - Želeno stanje & $\mathrm{II} 3$ & 0,260 & 0,005 \\
\hline Par C - kultura trga & Dejansko stanje - Želeno stanje & $\mathrm{II} 3$ & 0,190 & 0,044 \\
\hline $\begin{array}{l}\text { Par D - kultura hier- } \\
\text { arhije }\end{array}$ & Dejansko stanje - Želeno stanje & $\mathrm{II3}$ & 0,184 & $0,05 \mathrm{I}$
\end{tabular}

Razloge za razkorak med dejanskim in želenim stanjem lahko iščemo v razhajanju mnenj vodstva podjetij in zaposlenih o tem, kakšna naj bo organizacijska kultura v podjetju. Vodstvo in zaposleni na želeno kulturo organizacije gledajo z drugih zornih kotov; videnje načeloma izhaja iz različnih zasledovanj ciljev, pristojnosti in odgovornosti posameznih skupin.

Analizirali smo tudi, ali se mnenje anketiranih o prevladujoči organizacijski kulturi v podjetjih, kjer so zaposleni, razlikuje glede na posamezen vsebinski sklop in ali so razlike med dejanskim in želenim stanjem pomembne. $V$ predhodnih poglavjih smo predstavili deskriptivne podatke za spremenljivke, ki merijo dejansko in želeno stanje. Sedaj predstavljamo samo kulture $\mathrm{z}$ največjim številom točk po posameznem sklopu. V prvem sklopu, splošne karakteristike podjetja, prevladuje kultura trga ( 27 točk). V drugem sklopu, vodenje v organizaciji, je prevladujoča kultura trga (29 točk). V tretjem sklopu, sistem ravnanja z zaposlenimi, anketirani kot prevladujočo kulturo zaznajo kulturo klana (29 točk). V četrtem sklopu, lepilo organizacije, prevladuje kultura klana (28 točk). V petem sklopu, strateški poudarki, prevladujeta dve organizacijski kulturi - kultura trga in kultura hierarhije (27 točk). V zadnjem, šestem sklopu, kriterij uspeha, anketirani kot prevladujočo organizacijsko kulturo v podjetjih, kjer so zaposleni, zaznavajo kulturo hierarhije ( 32 točk). Pri vseh sklopih se kot prevladujoča organizacijska kultura, ki si jo anketirani v podjetjih, kjer so zaposleni, želijo v prihodnje, izpostavi kultura klana. 

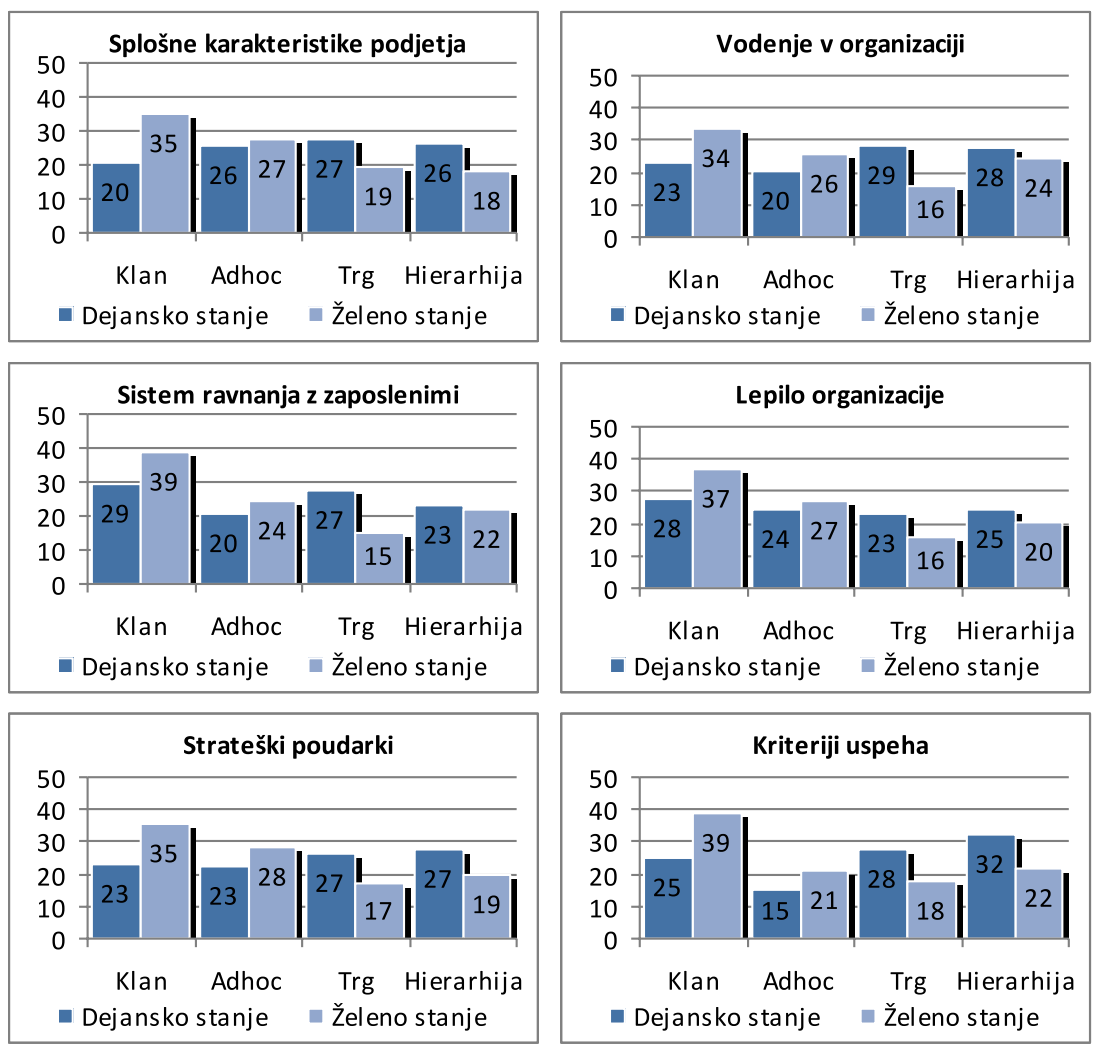

Slika 9.2: Vrednosti spremenljivk posameznega tipa organizacijske kulture

$S$ pomočjo Pearsonovega korelacijskega koeficienta (glej preglednico 9.9) smo preverjali korelacije med pari spremenljivk, ki merijo dejansko in želeno organizacijsko kulturo. Med pari spremenljivk, kjer obstajajo srednje močne korelacije, je stopnja značilnosti označena s krepkim tiskom.

Iz grafov razberemo, da obstajajo razlike med dejanskim in želenim stanjem organizacijske kulture $\mathrm{v}$ podjetjih, kjer so anketirani zaposleni. S pomočjo t-testa (glej prilogo 4 , tabela 6 ), smo primerjali posamezne pare spremenljivk (tiste, ki merijo dejansko organizacijsko kulturo $\mathrm{v}$ podjetjih, s tistimi, ki merijo želeno) in dokazovali, da so razlike med dejanskim in želenim stanjem organizacijske kulture po posameznih sklopih pomembne. Stopnja značilnosti je manjša od o,o5. Izjemo predstavljajo par spremenljivk v sklopu splošne karakteristike podjetja, ki meri ad hoc kulturo, par spremenljivk v sklopu vodenje v organizaciji, ki meri kulturo hierarhije, in par spremenljivk v sklopu sistem ravnanja z zaposle- 
nimi, ki meri kulturo hierarhije. Med temi pari spremenljivk razlike med dejanskim in želenim stanjem niso pomembne.

Preglednica 9.9: Pearsonov koeficient korelacije za pare spremenljivk štirih organizacijskih kultur po sklopih

\begin{tabular}{|c|c|c|c|c|}
\hline & & $\mathbf{N}$ & Korelacija & Stopnja značilnosti \\
\hline \multirow{4}{*}{$\begin{array}{l}\text { Splošne karakteris- } \\
\text { tike podjetja }\end{array}$} & Kultura klana & $\mathrm{II} 3$ & O,IOI & 0,286 \\
\hline & Ad hoc kultura & $\mathrm{II3}$ & 0,275 & 0,003 \\
\hline & Kultura trga & 113 & 0,164 & 0,082 \\
\hline & Kultura hierarhije & 113 & $-0,007$ & 0,940 \\
\hline \multirow{4}{*}{$\begin{array}{l}\text { Vodenje v organi- } \\
\text { zaciji }\end{array}$} & Kultura klana & $\mathrm{II} 3$ & 0,130 & 0,170 \\
\hline & Ad hoc kultura & $\mathrm{II3}$ & 0,128 & 0,176 \\
\hline & Kultura trga & $\mathrm{II3}$ & 0,115 & 0,226 \\
\hline & Kultura hierarhije & 113 & 0,112 & 0,239 \\
\hline \multirow{4}{*}{$\begin{array}{l}\text { Sistem ravnanja z } \\
\text { zaposlenimi }\end{array}$} & Kultura klana & 113 & 0,272 & 0,004 \\
\hline & Ad hoc kultura & $\mathrm{II} 3$ & 0,140 & 0,138 \\
\hline & Kultura trga & $\mathrm{II} 3$ & 0,117 & 0,215 \\
\hline & Kultura hierarhije & $\mathrm{II3}$ & 0,040 & 0,677 \\
\hline \multirow{4}{*}{ Lepilo organizacije } & Kultura klana & 113 & 0,152 & 0,107 \\
\hline & Ad hoc kultura & $\mathrm{II} 3$ & 0,343 & 0,000 \\
\hline & Kultura trga & $\mathrm{II} 3$ & 0,049 & 0,603 \\
\hline & Kultura hierarhije & $\mathrm{II} 3$ & 0,159 & 0,092 \\
\hline \multirow{4}{*}{ Strateški poudarki } & Kultura klana & $\mathrm{II} 3$ & 0,317 & 0,001 \\
\hline & Ad hoc kultura & 113 & 0,258 & 0,006 \\
\hline & Kultura trga & $\mathrm{II} 3$ & $-0,076$ & 0,422 \\
\hline & Kultura hierarhije & $\mathrm{II} 3$ & 0,244 & 0,009 \\
\hline \multirow{4}{*}{ Kriteriji uspeha } & Kultura klana & $\mathrm{II} 3$ & 0,248 & $0,0 \circ 8$ \\
\hline & Ad hoc kultura & 113 & 0,253 & 0,007 \\
\hline & Kultura trga & $\mathrm{II} 3$ & 0,312 & 0,001 \\
\hline & Kultura hierarhije & $\mathrm{II} 3$ & 0,360 & 0,000 \\
\hline
\end{tabular}

Vse to kaže, da so med dejanskim in želenim stanjem pomembna razhajanja. Želja po spremembi organizacijske kulture se lahko kaže v razhajanjih trenutnih in bodočih želenih koristi posameznikov in njihove identifikacije znotraj podjetja.

$\mathrm{Na}$ podlagi strokovne literature lahko predvidevamo želeno spremembo zgolj na objektivnih temeljih raziskave, ki smo jo opravili. Želeno 
spremembo kulture lahko vidimo $\mathrm{v}$ relativno mladih tujih podjetij, kjer si zaposleni na podlagi svojih predhodnih organizacijsko-kulturnih izkušenj želijo pretekli vzorec organizacijske kulture ter, kot rečeno, želenih individualnih koristi, ki jih pričakujejo od organizacije.

\section{Korelacijska matrika}

Korelacijska matrika je $\mathrm{v}$ pomoč pri ocenjevanju povezanosti med posameznimi spremenljivkami, ki določajo tip organizacijske kulture pri preučevanem vzorcu. Odločili smo se, da korelacijsko matriko naredimo samo med štirimi dimenzijami, med glavnimi štirimi tipi organizacijske kulture, saj nas zanima, ali obstajajo povezave med njimi. Na ta način bomo raziskali, ali so si organizacijske kulture med seboj podobne ali se popolnoma razlikujejo.

Preglednica 9.1 o: Korelacijska matrika

\begin{tabular}{|c|c|c|c|c|c|}
\hline & & Kultura klana & Ad hoc kultura & Kultura trga & $\begin{array}{r}\text { Kultura } \\
\text { hierarhije }\end{array}$ \\
\hline \multirow{3}{*}{ Kultura klana } & $\begin{array}{l}\text { Pearsonov koeficient } \\
\text { korelacije }\end{array}$ & I & 0,117 & $-0,760$ & $-0,318$ \\
\hline & Stopnja značilnosti & & 0,215 & 0,000 & 0,001 \\
\hline & $\mathrm{N}$ & 113 & 113 & $\mathrm{II} 3$ & II3 \\
\hline \multirow{3}{*}{ Ad hoc kultura } & $\begin{array}{l}\text { Pearsonov koeficient } \\
\text { korelacije }\end{array}$ & 0,117 & I & $-0,2 \mathrm{II}$ & $-0,634$ \\
\hline & Stopnja značilnosti & 0,215 & & 0,025 & 0,000 \\
\hline & $\mathrm{N}$ & 113 & 113 & 113 & $\mathrm{II} 3$ \\
\hline \multirow{3}{*}{ Kultura trga } & $\begin{array}{l}\text { Pearsonov koeficient } \\
\text { korelacije }\end{array}$ & $-0,760$ & $-0,2 \mathrm{II}$ & I & $-0,152$ \\
\hline & Stopnja značilnosti & 0,000 & 0,025 & & 0,108 \\
\hline & $\mathrm{N}$ & 113 & 113 & $\mathrm{II} 3$ & $\mathrm{II3}$ \\
\hline \multirow{3}{*}{$\begin{array}{l}\text { Kultura hier- } \\
\text { arhije }\end{array}$} & $\begin{array}{l}\text { Pearsonov koeficient } \\
\text { korelacije }\end{array}$ & $-0,318$ & $-0,634$ & $-0,152$ & I \\
\hline & Stopnja značilnosti & ०,००I & 0,000 & 0,108 & \\
\hline & $\mathrm{N}$ & $\mathrm{II} 3$ & $\mathrm{II} 3$ & $\mathrm{II} 3$ & $\mathrm{II} 3$ \\
\hline
\end{tabular}

** Korelacija je signifikantna na stopnji o,o I (2-tailed).

* Korelacija je signifikantna na stopnji o,os (2-tailed).

Iz preglednice 9.Io lahko razberemo, da obstajajo povezanosti med posameznimi organizacijskimi kulturami. S pomočjo Pearsonovega koeficienta korelacije lahko statistično značilno linearno korelacijo pri manj 
kot I-odstotnem tveganju potrdimo $\mathrm{z}$ izmerjeno vrednostjo - 0,760 , in sicer med spremenljivkama, ki merita kulturo klana in kulturo trga. $Z$ vrednostjo -0,634 jo potrdimo tudi med spremenljivkama, ki merita ad hoc kulturo in kulturo hierarhije. Ti korelaciji sta močni. Srednje močno povezavo $\mathrm{z}$ vrednostjo - $0,3 \mathrm{I} 8$ potrdimo med kulturo hierarhije in kulturo klana. Pri manj kot 5-odstotnem tveganju lahko z vrednostjo -0,2 I I potrdimo šibko korelacijo med spremenljivkama ad hoc kultura in kultura trga. Korelacija med kulturo klana in kulturo trga je razumljiva, saj obe kulturi delno temeljita na sodelovanju, katerega odraz je uspeh podjetja, pri čemer se $\mathrm{v}$ prvem primeru kaže tudi uresničevanje ciljev posameznika v sodelovanju v skupini, v drugem pa se uresničevanje ciljev posameznika kaže s pomočjo oziroma s primerjanjem uspeha z drugimi v skupini. Povezanost med ad hoc in kulturo hierarhije se kaže na eni strani v organiziranosti obvladljivosti, nekonfliktnosti, po drugi strani pa v želji po kreativnosti, tveganju in izvirnosti.

Iz korelacijske matrike lahko razberemo število močnejših korelacijskih »težišč«. Težišče v našem primeru predstavlja statistično značilno korelacijo med organizacijskimi kulturami, ki jo zaznamo. V našem primeru razberemo dve korelacijski težišči. Glede na rezultate korelacijske matrike lahko za prvo in drugo težišče potrdimo močno negativno povezavo (spremenljivk organizacijske kulture). Med ostalimi spremenljivkami se ne kažejo povezave, kar pomeni, da pri njih ne moremo pričakovati večjega vpliva splošnih (skupnih) faktorjev, temveč jih lahko pripišemo specifičnim faktorjem.

\section{Faktorska analiza}

Ali so preučevane organizacijske kulture med seboj povezane ali ne? $S$ faktorsko analizo smo preverili, ali na podlagi teorije organizacijske kulture tudi dejansko korelirajo med seboj oziroma tvorijo ustrezne faktorje.

Faktorsko analizo smo sprva poskušali narediti s pomočjo metode glavnih osi (PAF - Principal Axis Factoring), vendar postopek ni konvergiral. To pomeni, da omenjene analize teh podatkov ni bilo moč narediti s statističnega vidika. Zato smo jo naredili s pomočjo metode PCA (PCA - Principal Component Analysis) na štirih spremenljivkah in z rotacijo (varimax). Omenjeno metodo statistični paket SPSS samodejno predpostavi in jo prevajamo kot analizo glavnih komponent.

Prvi pogoj za izvedbo faktorske analize je zadostna soodvisnost med spremenljivkami. Ali podatki temu pogoju zadostijo, izračunamo s pomočjo korelacijske matrike. To smo storili že $\mathrm{v}$ prejšnjem poglavju in ugotovili, da spremenljivke med seboj korelirajo. Vrednosti korelacijskih ko- 
eficientov zavzemajo vrednosti med 0,15 in 0,76 (glej preglednico 9.10). Večja ko je vrednost korelacijskega koeficienta, večja je verjetnost, da boste spremenljivki razvrščeni $\mathrm{v}$ isti faktor. Na podlagi rezultatov korelacijske matrike smo predpostavili, da je linearno povezanost med spremenljivkami, ki merijo organizacijsko kulturo, možno pojasniti z dvema skupnima faktorjema.

Iz preglednice 9.II s celotno pojasnjeno varianco (Total Variance Explained) razberemo, kako se varianca razdeli med vse možne (štiri) faktorje. Da je faktor ustrezen, je treba zadostiti kriteriju višine pojasnjene variance. Da je nek faktor še ustrezen, mora biti izračun lastne vrednosti večji od $\mathrm{I}, \mathrm{O} . \mathrm{Z}$ dvema skupnima faktorjema lahko pojasnimo $86 \%$ celotne variabilnosti vrednosti spremenljivk, ki merijo tipe organizacijske kulture. Pri tem gledamo razdelek, ki prikazuje lastne vrednosti rotacije. Vidimo tudi, da se delež pojasnjene variance brez rotacije in z njo v skupnem seštevku ne razlikuje.

Preglednica 9. I : Celotna pojasnjena varianca

\begin{tabular}{ccccccccccc} 
& \multicolumn{2}{c}{ Začetne lastne vrednosti } & \multicolumn{2}{c}{ Izluščene lastne vrednosti } & \multicolumn{2}{c}{ Lastne vrednosti rotacije } \\
\cline { 2 - 9 } Faktor & Vrednost $\begin{array}{c}\% \text { vari- } \\
\text { ance }\end{array}$ & $\begin{array}{c}\text { Kumula- } \\
\text { tiva }(\%)\end{array}$ & Vrednost & $\begin{array}{c}\% \text { vari- } \\
\text { ance }\end{array}$ & $\begin{array}{c}\text { Kumula- } \\
\text { tiva }(\%)\end{array}$ & Vrednost & $\begin{array}{c}\% \text { vari- } \\
\text { ance }\end{array}$ & $\begin{array}{c}\text { Komula- } \\
\text { tiva }(\%)\end{array}$ \\
\hline I & 2,0 & 49,0 & 49,0 & 2,0 & 49,0 & 49,0 & 1,8 & $44, \mathrm{I}$ & $44, \mathrm{I}$ \\
\hline 2 & 1,5 & 36,7 & 85,7 & 1,5 & 36,7 & 85,7 & 1,7 & 41,6 & 85,7 \\
\hline 3 & 0,6 & 14,3 & 100,0 & & & & & & \\
\hline 4 & 0,0 & 0,0 & 100,0 & & & & & & \\
\hline
\end{tabular}

Iz matrike faktorskih uteži (preglednica 9.I2) je razvidno, da sta $\mathrm{v}$ prvi faktor zajeti spremenljivki kultura trga in kultura klana, $v$ drugi faktor pa spremenljivki kultura hierarhije in ad hoc kultura.

Preglednica 9.12: Faktorske uteži (rotacija)

\begin{tabular}{lcc} 
& \multicolumn{2}{c}{ Vrednosti rotiranih faktorskih uteži } \\
\hline Kultura trga & I. faktor & 2. faktor \\
\hline Kultura klana & $-0,959$ & \\
\hline Kultura hierarhije & 0,909 & $-0,935$ \\
\hline Ad hoc kultura & & 0,863 \\
\hline
\end{tabular}


Pri poimenovanju faktorjev se navezujemo na interpretacijo Camerona in Quinna (1999) in njuno poimenovanje tipov organizacijske kulture. Prvi faktor izpostavlja kulturo trga in kulturo klana. Kjer prevladuje kultura klana, si zaposleni pomagajo in zaupajo. Vodstvo in zaposleni sodelujejo, poudarjeni sta predanost in zvestoba združbi. V zameno pa družba skrbi za zaposlene, za njihovo izobraževanje in razvoj. Na drugi strani je v podjetjih, kjer prevladuje kultura trga, povsem drugače, pomembni so rezultati. Med zaposlenimi vlada tekmovalnost. Vodstvo želi doseči zastavljene cilje, izločiti konkurenco in biti vodilni na trgu. Prvi faktor imenujemo usmeritev $v$ odnose, ki so lahko usmerjeni navzven ali navznoter.

Drugi faktor izpostavlja kulturo hierarhije in ad hoc kulturo. Kultura hierarhije temelji na formalnih pravilih in kontroli. Pomembni sta organizacija in koordiniranje, tako da delo poteka tekoče. Izogibajo se nepredvidljivim situacijam in tudi konfliktom. Vodstvo in zaposleni cenijo zanesljivost in stabilnost. Zadovoljni so z obstoječim stanjem. Za ad hoc kulturo je značilno, da je združba dinamična, vodstvo in zaposleni so pripravljeni tvegati. Cenjeni sta inovativnost in izvirnost, saj se želijo na trgu predstaviti z vedno novimi proizvodi. Zato spodbujajo ustvarjalnost, iščejo vedno nove vire in nove priložnosti. Drugi faktor imenujemo usmeritev $v$ organizacijo dela, ki je lahko organizirana in hierarhična ali neorganizirana in ad hoc.

\section{Model regresijske analize}

S pomočjo regresijske analize smo poskušali odgovoriti na vprašanje, ali na izbiro prevladujočega tipa organizacijske kulture (odvisna spremenljivka) vplivajo spol, starost, delovna doba, tip zaposlitve in področje dela (neodvisne spremenljivke). Preverili smo tudi, katera izmed demografskih spremenljivk (spol, starost, delovna doba, tip zaposlitve in področje dela) najbolj vpliva na izbiro prevladujočega tipa organizacijske kulture. Za posamezen tip kulture imamo na voljo izvedeno spremenljivko. Tako smo za preverjanje našega vprašanja naredili štiri regresijske analize in z njihovo pomočjo poskušali ugotoviti, ali neodvisne spremenljivke vplivajo na izbiro prevladujočega tipa organizacijske kulture.

$S$ prvim regresijskim modelom smo preverjali, ali neodvisne spremenljivke vplivajo na odvisno spremenljivko kultura klana. Prvi regresijski model je smiseln, saj se statistično prilega podatkom, in sicer je značilen pri ničodstotni stopnji tveganja. Statistika $F$ znaša 4,425 pri statistični značilnosti ०,০০ . Determinacijski koeficient $\mathrm{R}^{2}$, ki je normaliziran glede na število neodvisnih spremenljivk, znaša 0,133 . To pomeni, da z neodvisnimi spremenljivkami pojasnimo ${ }_{13,3} \%$ celotne variance odvisne spre- 
menljivke. Standardni regresijski koeficienti $\beta$-e so statistično pomembni $(\mathrm{p}<0,05)$ za štiri neodvisne spremenljivke (spol, starost, tip zaposlitve in področje dela). Pri statistični značilnosti $(\mathrm{p}=0,022)$ in vrednosti beta koeficienta $(\beta)-0,207$ lahko trdimo, da moški v večji meri izbirajo kulturo klana za prevladujočo kulturo v podjetjih, kjer so zaposleni. Pri statistični značilnosti $(p=0,022)$ in vrednosti beta koeficienta $(\beta) 0,279$ lahko trdimo, da starejši kot so anketirani, bolj izbirajo kulturo klana za prevladujočo kulturo v podjetjih, kjer so zaposleni. Pri statistični značilnosti ( $\mathrm{p}$ $=0,03 \mathrm{I})$ in vrednosti beta koeficienta $(\beta)$-0,222 lahko trdimo, da anketirani, ki so redno zaposleni, v večji meri menijo, da je prevladujoča kultura $\mathrm{v}$ podjetjih, kjer so zaposleni, kultura klana. Zaposleni, ki nimajo redne oblike zaposlitve, so nasprotnega mnenja. Pri statistični značilnosti ( $\mathrm{p}=$ $0,025)$ in vrednosti beta koeficienta $(\beta)$ - 0,2 ro lahko trdimo, da anketirani, ki zasedajo osnovno raven zaposlitve, $v$ večji meri menijo, da je prevladujoča kultura v podjetjih, kjer so zaposleni, kultura klana. Zaposleni na višjih položajih so nasprotnega mnenja. Delovna doba anketiranih na izbor nima vpliva.

$\mathrm{Z}$ drugim regresijskim modelom smo preverjali, ali neodvisne spremenljivke vplivajo na odvisno spremenljivko ad hoc kultura. Drugi regresijski model ni smiseln, saj se statistično ne prilega podatkom. Statistika F znaša samo 0,236 in ni statistično pomembna $(\alpha=0,946)$.

$S$ tretjim regresijskim modelom smo preverjali, ali neodvisne spremenljivke vplivajo na odvisno spremenljivko kultura trga. Tretji regresijski model je smiseln, saj se statistično prilega podatkom, in sicer je značilen pri 6,4-odstotni stopnji tveganja. Statistika F znaša 2,160 pri statistični značilnosti o,o64. Determinacijski koeficient $\mathrm{R}^{2}$, ki je normaliziran glede na število neodvisnih spremenljivk, znaša 0,049 . To pomeni, da z neodvisnimi spremenljivkami pojasnimo $4,9 \%$ celotne variance odvisne spremenljivke. Standardni regresijski koeficienti $\beta$-e so statistično pomembni za dve odvisni spremenljivki.

Pri statistični značilnosti $(p=0,097)$ in vrednosti beta koeficienta (ß) o, 177 lahko trdimo, da anketirani, ki nimajo rednih oblik zaposlitve, $\mathrm{v}$ večji meri menijo, da je prevladujoča kultura v podjetjih, kjer so zaposleni, kultura trga. Zaposleni, ki imajo redno obliko zaposlitve, so nasprotnega mnenja. Pri statistični značilnosti $(\mathrm{p}=0,037)$ in vrednosti beta koeficienta $(\beta)$-o,20s lahko trdimo, da anketirani, ki zasedajo osnovno raven zaposlitve, $v$ večji meri menijo, da je prevladujoča kultura v podjetjih, kjer so zaposleni, kultura trga. Zaposleni na višjih položajih so nasprotnega mnenja. Ostale demografske spremenljivke (spol, starost in delovna doba) na izbor prevladujoče organizacijske kulture nimajo vpliva. 
$S$ četrtim regresijskim modelom smo preverjali, ali neodvisne spremenljivke vplivajo na odvisno spremenljivko kultura hierarhije. Četrti regresijski model ni smiseln, saj se statistično ne prilega podatkom. Statistika F znaša 1,537 in ni statistično pomembna $(\alpha=0,184)$.

V preglednici 9.13, ki predstavlja regresijsko analizo, so predstavljeni osnovni podatki vseh štirih regresijskih analiz (vrednost koeficientov b, standardna napaka koeficienta in bete).

Preglednica 9.1 3: Regresijska analiza

\begin{tabular}{|c|c|c|c|c|}
\hline & & B & SE B & $\beta$ \\
\hline \multirow{6}{*}{$\begin{array}{l}\text { Model I } \\
\text { Odvisna spremenljivka: } \\
\text { Kultura klana }\end{array}$} & Konstanta & 25 & 9 & \\
\hline & Spol & -5 & 2 & $-0,207$ \\
\hline & Starost & $\circ$ & $\circ$ & 0,279 \\
\hline & Delovna doba & $\circ$ & $\circ$ & $-0,077$ \\
\hline & Tip zaposlitve & -5 & 2 & $-0,222$ \\
\hline & Področje dela & 2 & I & 0,210 \\
\hline \multirow{6}{*}{$\begin{array}{l}\text { Model } 2 \\
\text { Odvisna spremenljivka: } \\
\text { Ad hoc kultura }\end{array}$} & Konstanta & $2 \mathrm{I}$ & 6 & \\
\hline & Spol & $\circ$ & 2 & 0,001 \\
\hline & Starost & $\circ$ & $\circ$ & 0,127 \\
\hline & Delovna doba & $\circ$ & $\circ$ & $-0,027$ \\
\hline & Tip zaposlitve & -1 & 2 & $-0,072$ \\
\hline & Področje dela & $\circ$ & I & $-0,035$ \\
\hline \multirow{6}{*}{$\begin{array}{l}\text { Model }_{3} \\
\text { Odvisna spremenljivka: } \\
\text { Kultura trga }\end{array}$} & Konstanta & 28 & 9 & \\
\hline & Spol & I & 2 & 0,050 \\
\hline & Starost & $\circ$ & $\circ$ & $-0,144$ \\
\hline & Delovna doba & $\circ$ & $\circ$ & 0,020 \\
\hline & Tip zaposlitve & 4 & 3 & 0,177 \\
\hline & Področje dela & -2 & I & $-0,205$ \\
\hline \multirow{6}{*}{$\begin{array}{l}\text { Model }_{4} \\
\text { Kultura hierarhije }\end{array}$} & Konstanta & 26 & 8 & \\
\hline & Spol & 4 & 2 & 0,171 \\
\hline & Starost & $\circ$ & $\circ$ & $-0,237$ \\
\hline & Delovna doba & $\circ$ & $\circ$ & 0,082 \\
\hline & Tip zaposlitve & 2 & 2 & 0,094 \\
\hline & Področje dela & $\circ$ & I & 0,029 \\
\hline
\end{tabular}


Zaključimo lahko, da na izbiro kulture klana vplivajo tako spol in starost kot tip zaposlitve in področje dela. Na izbiro kulture trga pa vpliva področje dela. Na ostala dva tipa organizacijske kulture ni vidnega vpliva neodvisnih spremenljivk.

\section{Uspešnost tujih podjetij v Sloveniji}

V sklopu našega raziskovanja smo analizirali uspešnost podjetij, ki zajemajo vzorec raziskave. Definicijo uspešnosti smo oblikovali na podlagi pozitivnega ali negativnega poslovnega izida. Omejitev določanja uspešnosti podjetij je več, vendar lahko kljub omejitvam dobimo nek splošen vpogled $\mathrm{v}$ podjetja v tuji lasti. Omejitve, s katerimi smo se soočali pri definiciji uspešnosti podjetij raziskovalnega vzorca, so naslednje:

- neupoštevanje panožne opredelitve podjetij;

- pri tujih podjetjih, ki so v Sloveniji sorazmerno mlada, se del investicij neposredno odraža v poslovnem izidu, kar tega neupravičeno negativno prikazuje;

- morebitna strukturna razčlenjenost podjetij lahko prikazuje nerealen poslovni izid (znotraj skupine podjetij se lahko oblikuje več pravnih oseb - npr. zaradi ločevanja operativnega poslovanja od premoženja podjetja).

V vzorec analize podjetij je bilo vključenih 396 podjetij.

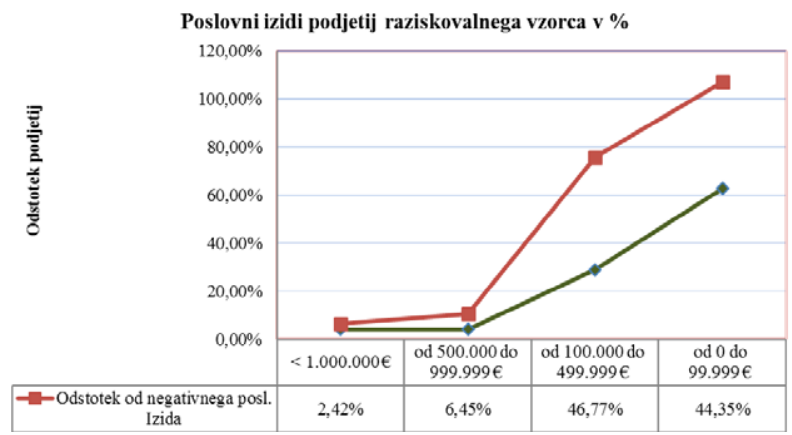

Slika 9.3: Poslovni izid podjetij raziskovalnega vzorca v \%

Graf (slika 9.3) prikazuje porazdelitev negativnega in pozitivnega poslovnega izida, razdeljeno po kategoriji razpona višine poslovnega izida. Pri podjetjih, ki ustvarijo pozitivni poslovni izid, v primerjavi s tistimi podjetji, ki ustvarijo negativni poslovni izid, se kaže največja odstotkovna razlika pri podjetjih, ki ustvarijo pozitivni poslovni izid, več- 
ji od 1.000 .000 EUR, in podjetjih, ki ustvarijo poslovni izid do 500.000 EUR. Zanimivo bi bilo ugotoviti, ali se podjetja iz skupine z najnižjim poslovnim izidom sčasoma premikajo $\mathrm{v}$ skupine $\mathrm{z}$ višjim pozitivnim poslovnim izidom.

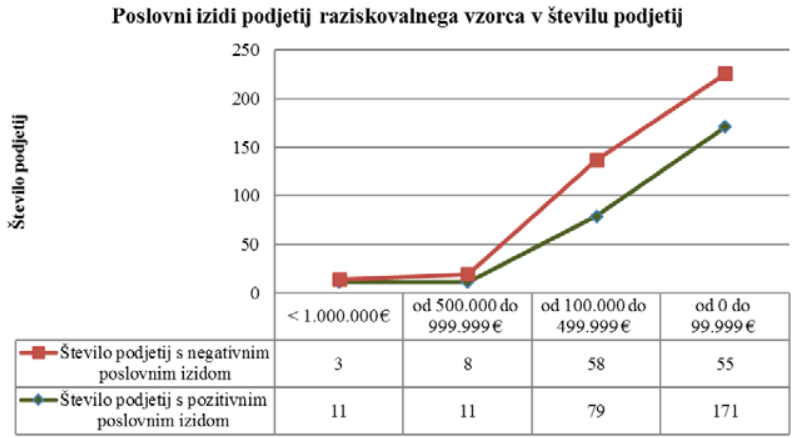

Slika 9.4: Poslovni izid podjetij raziskovalnega vzorca v številu podjetij

\section{Preverjanje hipotez}

HI: V slovenskih podjetjih s tujim lastništvom je prevladujoča or-

ganizacijska kultura tipa trg.

V poglavju Analiza tipa organizacijske kulture smo dokazali, da sta $\mathrm{v}$ našem vzorcu po mnenju anketiranih prevladujoči kar dve organizacijski kulturi, in sicer kultura hierarhije in kultura trga (obe s po 27 točk).

Nadalje smo preverjali, katera je prevladujoča organizacijska kultura anketiranih v podjetju, kjer so zaposleni, glede na posamezen tematski sklop. V prvem sklopu (splošne karakteristike podjetja) prevladuje kultura trga (27 točk). V drugem sklopu (vodenje v organizaciji) je prevladujoča kultura trga (29 točk). V tretjem sklopu (sistem ravnanja z zaposlenimi) anketirani kot prevladujočo kulturo zaznajo kulturo klana (29 točk). $\mathrm{V}$ četrtem sklopu (lepilo organizacije) prevladuje kultura klana (28 točk). $\mathrm{V}$ petem sklopu (strateški poudarki) prevladujeta dve kulturi - trga in hierarhije (27 točk). V zadnjem, šestem sklopu (kriterij uspeha) anketirani kot prevladujočo organizacijsko kulturo v podjetju, kjer so zaposleni, zaznavajo kulturo hierarhije ( 32 točk).

Hipoteze ne moremo potrditi v celoti, saj sta na splošno kot prevladujoči organizacijski kulturi navedena dva tipa kulture. Ker pa je eden izmed njiju kultura trga, lahko hipotezo $\mathrm{H}_{\mathrm{I}}$ delno potrdimo.

Hipoteza je bila postavljena na podlagi makroekonomskega videnja delovanja podjetij na trgu. Rezultate lahko interpretiramo na način, da vodstvo podjetja želi s pomočjo značilnosti kulture hierarhije s striktno 
organizacijsko urejenostjo doseči učinkovitejše delovanje organizacije v ekonomskem okolju, ki se odraža v kulturi trga.

H2: V slovenskih podjetjih s tujim lastništvom si zaposleni izrazi-

teje želijo organizacijsko kulturo tipa klan.

$\mathrm{V}$ poglavju Analiza tipa organizacijske kulture smo dokazali, da si v našem vzorcu anketirani v podjetjih, kjer so zaposleni, v prihodnje želijo kulture klana ( 37 točk). Glede na posamezen tematski sklop smo preverili tudi, katera je organizacijska kultura, ki si jo anketirani v podjetju, kjer so zaposleni, želijo v prihodnje. Pri vseh sklopih se kot prevladujoča organizacijska kultura, ki si jo anketirani v podjetju, kjer so zaposleni, želijo v prihodnje, izpostavi kultura klana. Hipotezo $\mathrm{H}_{2}$ potrdimo. Kultura klana najbolj potrdi željo zaposlenih po harmoničnem sodelovanju, kjer je tudi zaznava zaposlenih po dodani vrednosti največja.

$\mathrm{H}_{3}$ : $V$ slovenskih podjetjih s tujim lastništvom si zaposleni na vodstvenih položajih želijo drugačen tip organizacijske kulture, kot si ga želijo ostali zaposleni.

$\mathrm{V}$ poglavju Analize glede na spol, starost, zaposlitveno dobo, tip zaposlitve in delovno mesto smo prikazali rezultate prevladujočega tipa kulture, ki si ga anketirani v podjetjih, kjer so zaposleni, želijo v prihodnje. S pomočjo t-testa smo preverjali, ali lahko potrdimo tretjo hipotezo.

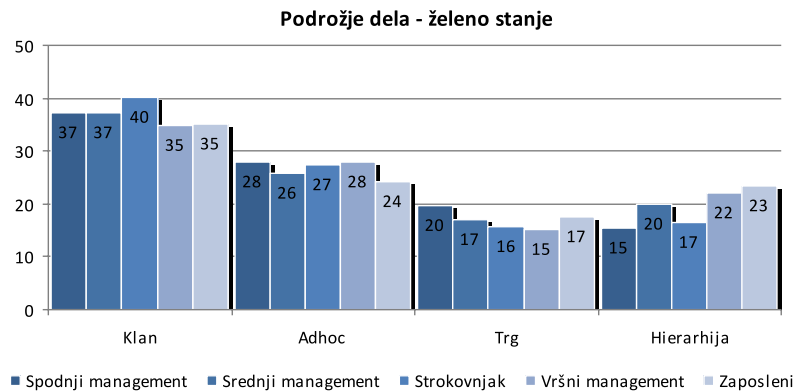

Slika 9.5: Ocena želene organizacijske kulture po področju dela

\section{Sklepi iz raziskave}

Glavni sklep empiričnega dela raziskave je, da si anketirani, ki so zaposleni v slovenskih podjetjih s tujim kapitalom, želijo kulture klana, kot prevladujoči kulturi v podjetju pa dojemajo kulturo trga in kulturo hierarhije. Ad hoc kultura med anketiranimi ni izpostavljena.

Anketirani delajo v okolju, kjer prevladujejo stabilnost, kontrola in uspešnost. $\mathrm{V}$ organizacijah, $\mathrm{v}$ katerih so zaposleni, je poslovna politika 
usmerjena v trženje, merilo uspeha je tržni delež. Poudarjeni sta konkurenčnost in produktivnost. Primarna dejavnost organizacij je izpolnitev cilja. Štejeta ugled in uspešnost. Organizacije imajo značilnosti tudi birokratske organizacije (delitev dela, hierarhična ureditev položajev, formalno in strukturirano delovno okolje, zapisana vodila).

Anketirani pa si v prihodnje želijo biti zaposleni v delovnem okolju, ki je prijazno, deluje kot velika družina, oziroma v okolju, kjer je poudarjen in omogočen osebni razvoj zaposlenih. $V$ takšnih delovnih sredinah vodilni skrbijo za zaposlene. Za uspešnost organizacije so pomembni dejavniki, kot so: spodbujajoče okolje za delo, timsko delo, medsebojno sodelovanje, dolgoročni osebni razvoj, razvita morala.

Vprašanje, ki se nam poraja, je, ali je kultura klana res organizacijska kultura, ki je primerna za vsako podjetje in ki lahko pripelje do uspešnega podjetja.

Kulturo klana bi lahko izpostavili kot družinsko ali prijateljsko delovanje znotraj organizacije, ki pri ljudeh psihološko sproži največ pozitivnih asociacij. Omenjena kultura podjetja uspešno deluje v panogah, kjer je zahtevano tesno sodelovanje, kreativnost ipd. V primeru velikih podjetij, kjer kompleksnost in delovanje podjetij navzven obsega veliko širino delovanja, struktura klana ne bi zmogla zagotoviti učinkovitega in uspešnega delovanja.

Pri raziskavi uspešnosti podjetij pa ne moremo popolnoma potrditi niti zavrniti trditve, da so tuja podjetja, ki v Sloveniji poslujejo $s$ tujo organizacijsko kulturo, uspešnejša od domačih, slovenskih podjetij. Na podlagi naše raziskave, $v$ katero je bilo zajetih 396 slovenskih podjetij s tujim lastništvom, se kaže tudi uspešnost le-teh. Pokaže se, da približno dve tretjini podjetij posluje s pozitivnim poslovnim izidom.

Potrditev uspešnosti teh podjetij, merjene na podlagi poslovnega izida, pa potrjuje tudi Modic (20I2), ki pravi, da lahko sodeč po rezultatih slovenska podjetja $v$ tuji lasti označimo za nekajkrat donosnejša od ostalega dela slovenskega gospodarstva. Prav tako meni, da je leto neuspešno zaključila manj kot desetina velikih »tujih« družb. Zanimiv je tudi podatek, da »tuje « družbe bolj kot obseg prihodkov zanima ustvarjanje dobička.

\section{Predviden prispevek k znanosti}

Prispevek k znanosti lahko opredelimo že v izhodišču glede na trenutno gospodarsko stanje v širšem okolju. Veliko podjetij se zaradi gospodarske krize ni uspelo odzvati na način, da bi ohranila oziroma izoblikovala svoj gospodarski položaj, pri čemer pomembno vlogo odigra tudi organizacij- 
ska kultura. Na to lahko navežemo misel, da imajo dolgoročno možnosti preživetja le tiste kulturne vsebine in oblike, ki so uspešne pri reševanju problemov. Organizacija lahko propade zaradi prepočasnega prilagajanja organizacijske kulture novim razmeram ali pa, če do prilagajanja sploh ne pride.

Kljub hudemu udarcu za slovensko gospodarstvo v zadnjih dveh letih opažamo razvoj in širitev tujih družb v Sloveniji, ki tako rekoč plavajo proti toku (UniCredit, Hofer, Lidl, Eurospin idr.). Te organizacije odlikuje organizacijska kultura, ki bistveno vpliva na možnost razvoja tudi v zaostrenih gospodarskih razmerah. Iz rezultatov ankete lahko razberemo tendence organizacijskih kultur tujih podjetij v Sloveniji. Te bi bilo v nadaljnji raziskavi smiselno primerjati s tendenčnimi organizacijskimi kulturami slovenskih podjetij in opozoriti na morebitne potrebne spremembe.

Splošne raziskave organizacijske kulture tujih podjetij v Sloveniji nismo zasledili. Omeniti velja naše razmišljanje o dodani vrednosti z vidika nadaljnjih raziskovalnih dejavnosti, katerih cilj bi lahko bila preučitev »uspešne « organizacijske kulture za slovenski gospodarski prostor.

Omejitev raziskave - (ne)reprezentativnost vzorca: porazdelitev po spolu in starosti je posledica naključno izbranega vzorca. Vzorec prav tako ni reprezentativen za slovenska podjetja s tujim kapitalom. Vse interpretacije se tako nanašajo na naš vzorec in jih ni mogoče posploševati na slovensko populacijo, zaposleno $v$ slovenskih podjetjih $s$ tujim kapitalom. Zaradi zanimivosti obravnavane teme in rezultatov predlagamo, da se nadaljnje podobne raziskave osredotočijo na reprezentativen vzorec slovenskih podjetij in zaposlenih $\mathrm{v}$ njih.

\section{Literatura}

Alvesson, M., in S. Sveningsson. 2008. Changing Organizational Culture Cultural Change Work in Progress. New York: Routledge.

Cameron, K. S., in R. E. Quinn. 1999. Diagnosing and Changing Organisational Culture. Reading: Addinson Wesley.

Kavčič, B. 2005. Organizacijska kultura. Celje: Visoka komercialna šola.

Kotter, J. P., in J. L. Heskett. 1992. Corporate Culture and Performance. New York: The Free Press.

Mesner-Andolšek, D. 1995. Organizacijska kultura. Ljubljana: GV založba.

Pečnik, B. 2008. »Organizacijska kultura hotelskega podjetja v slovenski Istri.« Magistrska naloga, Univerza na Primorskem. 
Schein, E. H. 1997. The Corporate Culture Survival Guide. San Francisco: Jossey-Bass.

SURS - Statistični urad Republike Slovenije. 2010. »Tuja notranja povezana podjetja, Slovenija, 2010 - končni podatki.« http://www.stat.si/novica_prikazi.aspx?id= 5030 .

Whitelock, J. 2002. »Theories Of Internationalisation and Their Impact on Market Entry.« International Marketing Review I9 (4): 342-47.

»Zakon o gospodarskih družbah (ZGD-I).« Uradni list $R S$, št. 42/2006. 



\title{
IO
}

\section{Organizacijska kultura}

v izbranih slovenskih srednje

velikih in velikih podjetjih

v Sloveniji

\author{
Tadeja Skok Matko in Mirko Markič
}

Definicij organizacijske kulture je veliko, vendar pa iz vseh lahko razberemo, da je to pomembna sestavina poslovanja organizacij in da je nujna za uspešnost poslovanja organizacij. Schein (1991, 247) organizacijsko kulturo definira na sledeči način: »Kultura je: vzorec skupnih temeljnih predpostavk, ki jih je iznašla, odkrila in razvila neka skupina, ko se je učila spopadati s problemi zunanje adaptacije in notranje integracije, in ki so se pokazale dovolj dobre, da jih je sprejela kot veljavne, zato naučijo nove člane skupine $\mathrm{v}$ odnosu do teh problemov zaznavati, misiti in čutiti po tem vzorcu.«

Prav tako kot je veliko definicij organizacijske kulture, je tudi več njenih tipologij (tipologija organizacijskih kultur Charlesa Handyja, tipologija Terrencea E. Deala in Allana A. Kennedyja, tipologija Manfreda Ketsa de Vriesa in Dannyja Millerja, tipologija R. E. Quinna in M. R. McGratha, tipologija Carterja McNamara ter tipologija Kima S. Camerona in Roberta E. Quinna) (Kavčič 201 I, 64-7I).

$\mathrm{Na}$ drugi strani pa smo preučevali zdravstveni absentizem. Pojmi »zdravstveni absentizem《, »začasna zadržanost od dela iz zdravstvenih razlogov《, »bolniški stalež« in »bolniška « so sinonimi, ki označujejo čas, ko zaposleni ne dela zaradi bolezni, poškodbe ali nege družinskega člana, pri čemer naj bi njegova nezmožnost za delo (ali zmanjšana delovna sposobnost) trajala omejen čas (Vučković 20IO, IO).

Zdravstveni absentizem je pomemben zaradi številnih negativnih posledic. Te so prisotne tako pri samih zaposlenih (na prvem mestu nižji dohodek, pa tudi manjše možnosti napredovanja, nezadovoljstvo v delovnem okolju, izguba delovnih navad in spretnosti itd.) kot pri delodajalcih 
(neposredni stroški za plačila nadomestil, stroški za nadomestne sodelavce, zmanjšana produktivnost itd.) in na ravni nacionalnega gospodarstva kot celote (nižji bruto domači proizvod) (Vučković 20ı,, Io).

Zavod za zdravstveno zavarovanje Slovenije (ZZZS) beleži v Sloveniji letno med Io in I milijonov izgubljenih delovnih dni, kar pomeni, da dnevno od dela izostane, zaradi bolezni ali poškodbe, približno med 38.500 in 39.000 zaposlenih (Vučkovič 2010, 17). Skupni letni strošek zaradi absentizma v Sloveniji se ocenjuje na 750 do 800 milijonov evrov (Strmec 2012, 3).

Najpogostejši vzrok za izostanek od dela so bolezni mišično-kostnega sistema in vezivnega tkiva, sledijo poškodbe in zastrupitve izven dela, nato pa bolezni dihal, poškodbe in zastrupitve pri delu ter duševne in vedenjske motnje (Vučkovič 20ı, 17).

Zaposleni naj bi bili ključni vir (tudi zmožnost, kapital ipd.) organizacije, o čemer se prepričamo, če preletimo vrednote, ki jih $\mathrm{v}$ podjetjih in drugih organizacijah navajajo v svojih predstavitvah. V vsaki je namreč omenjena pomembnost zaposlenih. Tam, kjer se zares zavedajo pomena zaposlenih za uspeh organizacije, se trudijo ustvariti pozitivno delovno vzdušje, kar zajema varno ter zdravju prijazno delovno okolje, dobre medosebne odnose in stimulativno delo, saj ti dejavniki prinašajo zdrave in zadovoljne zaposlene, ki so zaradi tega tudi manj na bolniškem dopustu.

\section{Namen raziskave}

Namen raziskave je bil ugotoviti, ali posamezen tip organizacijske kulture (hierarhija, trg, klan in adhokracija) statistično značilno vpliva na odstotek bolniškega staleža $\mathrm{v}$ velikem in $\mathrm{v}$ srednje velikem podjetju. Najprej smo ugotavljali posamezen tip organizacijske kulture, nato pa smo pridobili podatke, iz katerih smo izračunali odstotek bolniškega staleža. V ta namen smo izvedli empirično raziskavo na populaciji 230 srednje velikih in velikih gospodarskih družb v Sloveniji.

\section{Postopek in vzorec}

Raziskavo smo opravljali v času od I5. januarja 2014 do 30. junija 2014.

Z vprašalnikom smo pridobili podatke, iz katerih smo določili organizacijsko kulturo, in podatke o bolniški odsotnosti, iz katerih smo izračunali odstotek bolniškega staleža.

Namen empirične raziskave je bil preveriti naslednje hipoteze: 
- Hı: Prevladujoča organizacijska kultura tipa trg ima signifikantno negativen vpliv na odstotek bolniškega staleža zaposlenih v podjetju.

- H2: Prevladujoča organizacijska kultura tipa klan ima signifikantno pozitiven vpliv na odstotek bolniškega staleža zaposlenih $\mathrm{v}$ podjetju.

Vzorec smo oblikovali s pomočjo javno dostopne baze podjetij, ki so v poslovnem imeniku http://www.bizi.si/iskanje/ (I5. I. 20I4). V navedeni bazi je bilo po klasifikaciji za velika podjetja (več kot 50 zaposlenih) delujočih I.309 podjetij, omejili smo se na gospodarske družbe brez javnih zavodov. Vsa ta podjetja smo najprej kontaktirali po telefonu, poskusili priti v stik z vodji kadrovskih služb in jih prosili za sodelovanje v raziskavi. Vodje kadrovskih služb smo si izbrali, ker imajo dovolj znanja, da lahko odgovorijo na prvi del vprašalnika in s tem določijo organizacijsko kulturo podjetja, istočasno pa imajo tudi vse podatke o bolniških odsotnostih. Vprašalnik skupaj s spremnim dopisom pa smo nato posredovali po elektronski pošti. V spremnem dopisu smo razložili namen ankete, ocenili čas, potreben za izvedbo ankete, dali zagotovilo za varnost podatkov in njihovo uporabo, navedli kontaktno osebo za dodatna vprašanja in rok za vrnitev izpolnjene ankete.

Od I.309 gospodarskih družb, ki smo jih osebno kontaktirali po telefonu, je v anketiranje privolilo 340 vodij kadrovskih služb, ki smo jim nato poslali anketni vprašalnik po elektronski pošti, in od 340 poslanih anketnih vprašalnikov smo dobili vrnjenih 70 vprašalnikov.

Podatke, pridobljene $\mathrm{z}$ anketiranjem, smo najprej oblikovali v MS Excelovi tabeli. Tako pripravljene podatke smo nato prenesli v programsko orodje IBM SPSS Statistics 22, kjer smo jih podrobneje statistično obdelali. Opravili smo analizo variance, s katero smo primerjali \% BS pri posameznem tipu organizacijske kulture. Dobljeni rezultat smo še enkrat preverili $z$ analizo variance za indeks onesposabljanja. Nato pa smo naredili še t-preskus, $s$ katerim smo preverjali odvisnost med dejavnostjo podjetja (podjetja smo razdelili na izdelovalna in storitvena) in odstotkom bolniškega staleža.

\section{Opis merskega instrumenta}

Kot orodje raziskave smo uporabili vprašalnik zaprtega tipa. S prvim delom vprašalnika smo ugotavljali tip organizacijske kulture organizacije, ki ji pripada anketiranec. Za prvi del vprašalnika smo uporabili vprašalnik avtorjev Camerona in Quinna iz knjige Diagnosing and Changing 
Organizational Culture (2006, 26-28). Prvi del vprašalnika je sestavljen iz šestih sestavin, ki ugotavljajo: I) prevladujoče značilnosti organizacije, 2) vodenje organizacije, 3) management zaposlenih, 4) organizacijsko povezanost, 5) strateške usmeritve in 6) kriterije uspešnosti. Vsaka od teh šestih sestavin je sestavljena iz štirih trditev $(A, B, C, D)$ in med te trditve je moral anketiranec razdeliti Ioo točk največ točk se pripiše tisti trditvi, ki najbolj ustreza stanju v podjetju. Nato pa smo sešteli točke, ki pripadajo trditvam A, B, C in D: tisti anketni vprašalniki, ki so imeli največ točk pri trditvah $A$, pripadajo tipu organizacijske kulture klan; tista podjetja, ki imajo največ točk pri trditvah pod oznako B pripadajo organizacijski kulturi tipa adhokracija; podjetja, ki imajo največ točk pri trditvah pod oznako C, pripadajo organizacijski kulturi tipa trg; podjetja, ki imajo največ točk pri trditvah pod oznako D, imajo organizacijsko kulturo tipa hierarhija. Ugotavljali smo samo prevladujoči tip obstoječe organizacijske kulture v podjetju in ne tudi željene organizacijske kulture, kot je vprašalnik prvotno zasnovan.

Drugi del vprašalnika je bil namenjen pridobivanju podatkov o bolniški odsotnosti, iz katerih smo lahko izračunali odstotek bolniškega staleža (odstotek bolniškega staleža je odstotek izgubljenih delovnih dni na enega zaposlenega sodelavca) in indeks onesposabljanja (to je število izgubljenih delovnih dni na enega zaposlenega). Spraševali smo tudi po številu primerov bolniške odsotnosti, da bi lahko izračunali resnost (povprečno trajanje ene odsotnosti z dela zaradi bolezni, poškodbe ali drugega zdravstvenega razloga) vendar tega podatka nismo dobili od $39 \%$ anketiranih, zato ga nismo mogli uporabiti v statistični analizi.

$S$ tretjim delom vprašalnika smo pridobili podatke o podjetju, in sicer: povprečno število zaposlenih v letu 2013 ter dejavnost in starost podjetja.

\section{Analiza in interpretacija raziskave}

\section{Demografski podatki podjetij}

Od 67 anketiranih podjetij jih je 59,7\% (40) v izdelovalni dejavnosti in $40,3 \%(27)$ v storitveni dejavnosti. 19,4 \% anketiranih podjetij deluje do 20 let, $25 \%$ jih deluje med $2 \mathrm{I}$ in 40 let in prav tako $25 \%$ jih deluje med $4 \mathrm{I}$ in 60 let. Od 6I do 80 let delujočih podjetij je I I,9\%, od 8I do roo let delujočih podjetij je 7,5\%, 4,5\% anketiranih podjetij deluje med IOI in I 20 let, po $3 \%$ pa deluje med 121 in 140 let, med $14 \mathrm{I}$ in 160 let ter med $16 \mathrm{I}$ in I 80 let. Po številu zaposlenih je med anketiranimi 35,8 \% takšnih, ki sodijo med srednje velika podjetja (od 50 do I50 zaposlenih), preostalih 64,2 $\%$ anketiranih podjetij pa sodi med velika podjetja z nad 300 zaposlenimi. 
Dejavnost podjetja

\begin{tabular}{|c|c|c|}
\hline Izdelovalna dejavnost & 40 & 59,70 \\
\hline Storitvena dejavnost & 27 & 40,30 \\
\hline Skupaj & 67 & 100 \\
\hline \multicolumn{3}{|c|}{ Starost podjetja v letih } \\
\hline $\mathrm{I}-20$ & 13 & 19,40 \\
\hline $2 \mathrm{I}-40$ & 16 & 23,88 \\
\hline $4 I-60$ & 16 & 23,88 \\
\hline $6 \mathrm{I}-80$ & 8 & $\mathrm{II}, 94$ \\
\hline $8 \mathrm{I}-\mathrm{I00}$ & 5 & 7,46 \\
\hline $10 I-120$ & 3 & 4,48 \\
\hline $12 I-140$ & 2 & 2,99 \\
\hline $141-160$ & 2 & 2,99 \\
\hline $161-180$ & 2 & 2,99 \\
\hline Skupaj & 67 & 100 \\
\hline \multicolumn{3}{|c|}{ Śtevilo zaposlenih } \\
\hline $50-150$ & 24 & 35,82 \\
\hline $15 \mathrm{I}-300$ & 28 & 41,79 \\
\hline $301-500$ & 4 & 5,97 \\
\hline $501-750$ & 5 & 7,46 \\
\hline $75^{-1.050}$ & 2 & 2,99 \\
\hline $1.05 \mathrm{I}-\mathrm{I} .400$ & 4 & 5,97 \\
\hline Skupaj & 67 & 100 \\
\hline
\end{tabular}

\section{Analiza organizacijske kulture}

Obstoječo organizacijsko kulturo v podjetjih, ki so sodelovala v raziskavi, smo ugotavljali z vprašalnikom OCAI, ki loči štiri prevladujoče tipe organizacijskih kultur: hierarhijo, trg, klan in adhokracijo. Tako smo glede na prevladujoči tip organizacijske kulture dobili štiri skupine podjetij. Od 67 anketiranih podjetij jih ima $37,3 \%$ (25) organizacijsko kulturo tipa trg, 35,8 \% (24) organizacijsko kulturo tipa klan, 13,4 \% (9) organizacijsko kulturo tipa hierarhija in prav toliko tipa adhokracija. 


\begin{tabular}{lcc} 
& Frekvenca & Delež $(\mathrm{v} \%)$ \\
\hline Hierarhija & Organizacijska kultura & \\
\hline $\operatorname{Trg}$ & 9 & 13,43 \\
\hline Klan & 25 & 37,31 \\
\hline Adhokracija & 24 & 35,82 \\
\hline Skupaj & 9 & 13,43 \\
\hline & 67 & 100 \\
\hline
\end{tabular}

Trditve, ki se nanašajo na organizacijsko kulturo, so anketirani ocenili z ocenami od o do Ioo tako, da so Ioo točk razdelili med štiri trditve in najvišjo oceno dali tisti trditvi, ki najbolje opisuje razmere v njihovi organizaciji.

Preglednica 10.3: Prevladujoče značilnosti organizacije
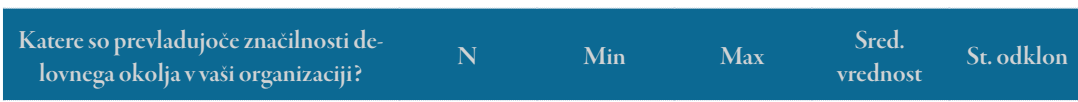

Delovno okolje v naši organizaciji je zelo oseben prostor. Je kot razširjena družina. Ljudje med seboj dobro sodelujejo.

$\begin{array}{lllll}67 & 0 & 100 & 28,03 & 24,38\end{array}$

Delovno okolje v naši organizaciji je zelo dinamično in podjetniško naravnano. Ljudje so se pripravljeni izpostaviti in prevzeti tveganje.

Delovno okolje v naši organizaciji je zelo usmerjeno k doseganju rezultatov. $\mathrm{Na}$ jpomembnejše je dokončati nalogo. Ljudje so zelo tekmovalni in naravnani $\mathrm{k}$ doseganju ciljev.

Delovno okolje v naši organizaciji je zelo nadzorovano in strukturirano. Ljudje se morajo d opravljanju svojega dela ržati 67 $\circ$ 100 20,25 formalnih postopkov in pravil pri.

Prvi sklop trditev ugotavlja glavne značilnosti organizacije. Najnižja povprečna ocena je bila izračunana pri trditvi Delovno okolje v naši organizaciji je zelo usmerjeno $k$ doseganju rezultatov. Najpomembnejše je dokončati nalogo. Ljudje so zelo tekmovalni in naravnani k doseganju ciljev. Sledi trditev z izračunano srednjo vrednostjo 20,25: Delovno okolje v naši organizaciji je zelo dinamično in podjetniško naravnano. Ljudje so se prip- 
ravljeni izpostaviti in prevzeti tveganje. Srednja vrednost 28,03 je izračunana pri trditvi Delovno okolje v naši organizaciji je zelo oseben prostor. Je kot razširjena družina. Ljudje med seboj dobro sodelujejo. Najvišja srednja vrednost 32,2 I pa je izračunana pri trditvi Delovno okolje v naši organizaciji je zelo nadzorovano in strukturirano. Ljudje se morajo pri opravljanju svojega dela držati formalnih postopkov in pravil.

Preglednica I0.4: Vodenje organizacije

\begin{tabular}{lccccc} 
Kakšno je vodstvo vaše organizacije? & N & Min & Max & $\begin{array}{c}\text { Sred. } \\
\text { vrednost }\end{array}$ & St. odklon \\
$\begin{array}{l}\text { Menim, da je vodstvo v naši organizaciji } \\
\text { zgled dobrega svetovanja (mentoriranja), } \\
\text { podpiranja in skrbi za zaposlene. }\end{array}$ & 67 & 0 & 70 & 27,13 & 18,984 \\
\hline $\begin{array}{l}\text { Menim, da je vodstvo v naši organizaciji } \\
\text { zgled dobrega podjetništva, inoviranja in } \\
\text { sprejemanja tveganja. }\end{array}$ & 67 & 0 & 100 & 25,33 & 18,638 \\
\hline $\begin{array}{l}\text { Menim, da je vodstvo v naši organizaciji } \\
\text { zgled dobrega, agresivnega in na rezultat } \\
\text { osredotočenega managementa. }\end{array}$ & 67 & 0 & 100 & 21,8 & 23,058 \\
\hline $\begin{array}{l}\text { Menim, da je vodstvo v naši organizaci- } \\
\text { ji zgled, kako z dobro koordinacijo in or- } \\
\text { ganiziranjem dela doseči splošno učinko- } \\
\text { vitost. }\end{array}$ & 67 & & & & \\
\hline
\end{tabular}

Drugi sklop ugotavlja stil vodenja $\mathrm{v}$ organizaciji in najnižji srednja vrednost 21,8 je izračunana pri trditvi Menim, da je vodstvo $v$ naši organizaciji zgled dobrega, agresivnega in na rezultat osredotočenega managementa. Srednja vrednost 25,33 je izračunana pri trditvi Menim, da je vodstvo $v$ naši organizaciji zgled dobrega podjetništva, inoviranja in sprejemanja tveganja. Naslednja srednja vrednost je zelo blizu prejšnji in sicer 25,74, izračunana pa je pri trditvi Menim, da je vodstvo v naši organizaciji zgled, kako z dobro koordinacijo in organiziranjem dela doseči splošno učinkovitost. Najvišja srednja vrednost 27,13 pa je izračunana pri trditvi Menim, da je vodstvo v naši organizaciji zgled dobrega svetovanja (mentoriranja), podpiranja in skrbi za zaposlene. 


\section{Kakšen je stil vodenja zaposlenih v vaši or-} ganizaciji?

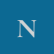

Min

Max

Sred. vrednost

St. odklon

Timsko delo, iskanje konsenza in sodelovanje so glavne značilnosti stila vodenja v naši organizaciji.

Tveganje posameznika, inovativnost, svoboda in edinstvenost so glavne značilnosti stila vodenja v naši organizaciji.

Izrazita tekmovalnost, visoke zahteve in dosežki so glavne značilnosti stila vodenja v naši organizaciji.

Skrb za varnost zaposlitve, prilagodljivost in stabilnost v medosebnih odnosih so glavne značilnosti stila vodenja v naši organizaciji.

Preglednica ı 0.6: Organizacijska povezanost

67

67

67
0

39,1

22,296

\section{N} jiv celoto?
Kaj povezuje zaposlene v vaši organizacijiv celoto?

Tisto, kar povezuje zaposlene, sta zvestoba in medsebojno zaupanje zaposlenih. Zavezanost tej organizaciji je visoka.

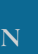

Min

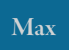

\section{Sred. vred- nost}

St. odklon

100

36,56

26,308

Tisto, kar povezuje zaposlene, je zavezanost inovacijam in razvoju. Tveganje je naše osnovno vodilo.

67

$\circ$

(1)

67

35

II, 23

9,817

Tisto, kar povezuje zaposlene, je poudarek na dosežkih in doseganju ciljev. Agresivnost in zmagovanje sta naši glavni značilnosti.

67

$\circ$

55

14,34

14,648

Tisto, kar povezuje zaposlene, so formalna pravila in usmeritve. Najpomembnejša naloga je vzdrževanje stabilnega delovanja organizacije.

Tretji sklop identificira sistem ravnanja z zaposlenimi in najnižja srednja vrednost 15,49 je pri trditvi Izrazita tekmovalnost, visoke zahteve in dosežki so glavne značilnosti stila vodenja $v$ naši organizaciji. 18,2 je srednja vrednost pri trditvi Tveganje posameznika, inovativnost, svoboda in edinstvenost so glavne značilnosti stila vodenja $v$ naši organizaciji. $\mathrm{Na}-$ slednja srednja vrednost, 26,97, je izračunana pri trditvi Skrb za varnost zaposlitve, prilagodljivost in stabilnost v medosebnih odnosih so glavne značilnosti stila vodenja v naši organizaciji. Najvišjo srednjo vrednost 39, I pa 
ima trditev Timsko delo, iskanje konsenza in sodelovanje so glavne značilnosti stila vodenja $v$ naši organizaciji.

Četrti sklop ugotavlja, kaj je tisto, kar povezuje zaposlene, in najnižja srednja vrednost, I I,23, je izračunana pri trditvi Tisto, kar povezuje zaposlene, je zavezanost inovacijam in razvoju. Tveganje je naše osnovno vodilo. Srednja vrednost 14,34 je izračunana pri trditvi Tisto, kar povezuje zaposlene, je poudarek na dosežkih in doseganju ciljev. Agresivnost in zmagovanje sta naši glavni značilnosti. Sledi izračunana srednja vrednost 36,56 pri trditvi Tisto, kar povezuje zaposlene, sta zvestoba in medsebojno zaupanje zaposlenih. Zavezanost tej organizaciji je visoka. Najvišja srednja vrednost 38,03 pa je izračunana pri trditvi Tisto, kar povezuje zaposlene, so formalna pravila in usmeritve. Najpomembnejša naloga je vzdrževanje stabilnega delovanja organizacije.

Preglednica i0.7: Strateške usmeritve

\begin{tabular}{|c|c|c|c|c|c|}
\hline $\begin{array}{l}\text { Kakšne so strateške usmeritve v vaši orga- } \\
\text { nizaciji? }\end{array}$ & $\mathbf{N}$ & Min & Max & $\begin{array}{c}\text { Sred. } \\
\text { vrednost }\end{array}$ & St. odklon \\
\hline $\begin{array}{l}\text { Organizacija poudarja razvoj zaposlen- } \\
\text { ih. Značilni so visoko zaupanje, odkritost in } \\
\text { sodelovanje. }\end{array}$ & 67 & $\circ$ & 70 & 20,82 & 17,611 \\
\hline $\begin{array}{l}\text { Organizacija poudarja razvoj novih program- } \\
\text { ov in ustvarjanje novih izzivov. Preizkušanje } \\
\text { novih stvari in iskanje priložnosti je cenjeno. }\end{array}$ & 67 & $\circ$ & 55 & 18,28 & 13,475 \\
\hline $\begin{array}{l}\text { Organizacija poudarja konkurenčnost in dose- } \\
\text { ganje rezultatov. Najpomembnejše je dosegan- } \\
\text { je zastavljenih ciljev in biti boljši od organizacij } \\
\text { s podobnimi programi. }\end{array}$ & 67 & $\circ$ & $8 \circ$ & 29,02 & 20,511 \\
\hline $\begin{array}{l}\text { Organizacija poudarja stabilnost in trajnost de- } \\
\text { lovanja. Pomembno je biti učinkovit, obdržati } \\
\text { nadzor in delovati brez motenj. }\end{array}$ & 67 & $\circ$ & 100 & 31,89 & 21,334 \\
\hline
\end{tabular}

Sklop strateške usmeritve ima najnižjo srednjo vrednost $\mathrm{I} 8,28$ pri trditvi Organizacija poudarja razvoj novih programov in ustvarjanje novih izzivov. Preizkušanje novih stvari in iskanje priložnosti je cenjeno. Sledi srednja vrednost 20,82 pri trditvi Organizacija poudarja razvoj zaposlenih. Značilni so visoko zaupanje, odkritost in sodelovanje. 29,02 je srednja vrednost, izračunana pri trditvi Organizacija poudarja konkurenčnost in doseganje rezultatov. Najpomembnejš je doseganje zastavljenih ciljev in biti boljši od organizacij s podobnimi programi. Najvišjo srednjo vrednost v petem sklopu, 31,89, ima trditev Organizacija poudarja stabilnost 
in trajnost delovanja. Pomembno je biti učinkovit, obdržati nadzor in delovati brez motenj.

Preglednica I o.8: Kriteriji uspešnosti

\begin{tabular}{lccccc}
\multicolumn{1}{c}{ Kateri so kriteriji uspešnosti? } & N & Min & Max & $\begin{array}{c}\text { Sred. } \\
\text { vrednost }\end{array}$ & St. odklon \\
$\begin{array}{l}\text { Organizacija opredeljuje svojo uspešnost na os- } \\
\text { novi razvoja zaposlenih, timskega dela, predanosti } \\
\text { zaposlenih in skrbi za ljudi. }\end{array}$ & 67 & 0 & 100 & 25,82 & 23,562 \\
\hline $\begin{array}{l}\text { Organizacija opredeljuje svojo uspešnost na os- } \\
\text { novi edinstvenosti in modernosti svojih program- } \\
\text { ov. Organizacija »orje ledino«. }\end{array}$ & 67 & 0 & 40 & 11,56 & II,816 \\
$\begin{array}{l}\text { Organizacija opredeljuje svojo uspešnost na os- } \\
\text { novi prehitevanja konkurenčnih organizacij. Kl- } \\
\text { jučno je konkurenčno, k trgu usmerjeno vodenje. }\end{array}$ & 67 & 0 & 100 & 24,67 & 22,133 \\
\hline $\begin{array}{l}\text { Organizacija opredeljuje svojo uspešnost na os- } \\
\text { novi učinkovitosti. Ključno je sistematično načr- } \\
\text { tovanje dela in s tem čim manjša poraba sredstev. }\end{array}$ & 67 & 0 & 100 & 37,95 & 26,792 \\
\hline
\end{tabular}

Zadnji sklop ugotavljanja organizacijske kulture identificira kriterije uspešnosti in najnižjo srednjo vrednost, I I,56, ima trditev Organizacija opredeljuje svojo uspešnost na osnovi edinstvenosti in modernosti svojih programov. Organizacija »orje ledino«. Naslednja srednja vrednost, 24,67, je izračunana pri trditvi Organizacija opredeljuje svojo uspešnost na osnovi prehitevanja konkurenčnih organizacij. Ključno je konkurenčno, $k$ trgu usmerjeno vodenje. Sledi srednja vrednost 25,82 pri trditvi Organizacija opredeljuje svojo uspeřnost na osnovi razvoja zaposlenih, timskega dela, predanosti zaposlenih in skrbi za ljudi. Najvišja srednja vrednost zadnjega sklopa znaša 37,95, in sicer pri trditvi Organizacija opredeljuje svojo uspeřnost na osnovi učinkovitosti. Ključno je sistematično načrtovanje dela in s tem čim manjša poraba sredstev.

Na podlagi analize trditev instrumenta OCAI smo grafično ponazorili (slika ı.. I) povprečno strukturo organizacijske kulture podjetij, ki so sodelovali v raziskavi. Ugotavljamo, da sta v slovenskih srednje velikih in velikih organizacijah prevladujoči organizacijski kulturi tipa klan s povprečno oceno 29,95 in hierarhija s povprečno oceno 31,09, ki sta skoraj enako močno zastopani. Slabše pa sta zastopana tipa organizacijske kulture adhokracija s povprečno oceno I5,66 in trg s povprečno oceno 20,I6. 


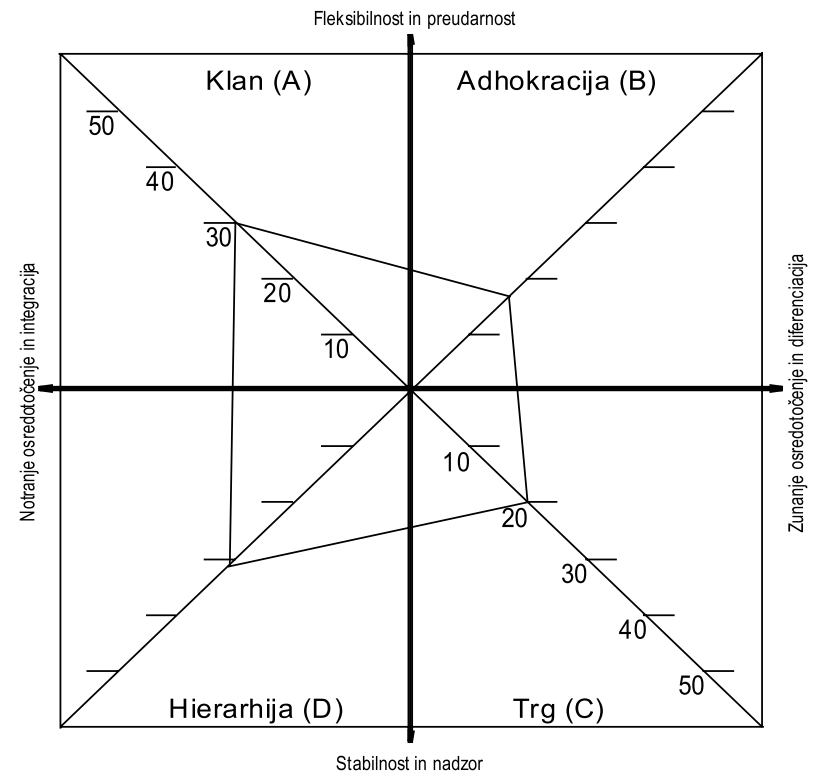

Slika ı. I: Povprečje strukture organizacijskih kultur podjetij, ki so sodelovala v raziskavi

\section{Analiza odstotka bolniškega staleža glede na tip organizacijske kulture}

Nadalje pa smo ugotavljali odstotek bolniškega staleža (\% BS), ki je odstotek izgubljenih delovnih dni na enega zaposlenega. Odstotek bolniškega staleža smo izračunali s formulo:

\footnotetext{
$\% \mathrm{BS}=\frac{\text { število izgubljenih delovnih } \mathrm{dni} \times \mathrm{I} 100}{\text { povprečno število zaposlenih } \mathrm{x} 312}$
}

Podatek o številu izgubljenih delovnih dni ter o povprečnem številu zaposlenih smo pridobili z drugim delom vprašalnika. Spraševali smo po podatkih za leto 2013 . Podatek o številu izgubljenih delovnih dni ter povprečno število zaposlenih smo vnesli $v$ Excelovo tabelo in $\mathrm{z}$ vstavljeno zgornjo formulo izračunali odstotek bolniškega staleža za vsa anketirana podjetja.

Nato pa smo opravili deskriptivne statistike odstotka bolniškega staleža za skupine podjetij z istim tipom prevladujoče organizacijske kulture. Rezultati so razvidni iz preglednice io.9. Razberemo lahko, da je povprečni odstotek bolniškega staleža najvišji pri podjetjih z organizacijsko kulturo klan, in sicer 3,706 odstotkov, najnižji povprečni odstotek bol- 
niškega staleža pa je v podjetjih z organizacijsko kulturo tipa adhokracija, 2,999 odstotkov. Pri organizacijski kulturi tipa adhokracija so bili podatki o odstotku bolniškega staleža tudi najhomogenejšii, najmanj homogeni pa so bili podatki o odstotku bolniškega staleža pri organizacijski kulturi tipa trg.

Preglednica 10.9: Deskriptivne statistike indeksa onesposabljanja pri skupinah podjetij z enakim prevladujočim tipom organizacijske kulture

\begin{tabular}{lllllll}
$\begin{array}{c}\text { Tip organizacijske kul- } \\
\text { ture }\end{array}$ & N & Min & Max & $\begin{array}{c}\text { Sred. } \\
\text { vrednost }\end{array}$ & Mediana & St. odklon \\
Hierarhija & 9 & I & 21,04 & 10,357 & 10,336 & 6,012 \\
\hline $\operatorname{Trg}$ & 25 & 0,4 & 21,42 & 10,683 & 8,092 & 5,853 \\
\hline Klan & 24 & 5,12 & 21,2 & 11,564 & 11,471 & 4,588 \\
\hline Adhokracija & 9 & 4,56 & 13,83 & 9,355 & 9,161 & 3,512 \\
\hline Skupaj & 67 & 11,08 & 77,49 & 41,959 & 39,06 & 19,965 \\
\hline
\end{tabular}

\section{Analiza odstotka bolniškega staleža glede na dejavnost podjetja}

Naredili smo tudi deskriptivne statistike odstotka bolniškega staleža glede na dejavnost podjetja in ugotovili, da se povprečni odstotek bolniškega staleža malo razlikuje glede na to, ali gre za podjetja, v katerih se ukvarjajo z izdelovalno, ali za tista, $\mathrm{v}$ katerih se ukvarjajo $s$ storitveno dejavnostjo. Nekoliko višji, in sicer za o, I odstotek, je povprečni odstotek bolniškega staleža v storitvenih organizacijah.

Preglednica ı o. I o: Deskriptivne statistike odstotka bolniškega staleža glede na dejavnost podjetja

\begin{tabular}{lcccccc} 
Dejavnost podjetja & N & Min & Max & Sred. vrednost & Mediana & St. odklon \\
Izdelovalna podjetja & 40 & 1,46 & 6,79 & 3,399 & 3,304 & 1,508 \\
\hline Storitvena podjetja & 27 & 0,13 & 6,86 & 3,498 & 3,256 & 1,79 \\
\hline Skupaj & 67 & 1,59 & 13,65 & 6,897 & 6,56 & 3,298 \\
\hline
\end{tabular}

\section{Preverjanje hipotez}

HI: Prevladujoča organizacijska kultura tipa trg ima signifikantno negativen vpliv na odstotek bolniškega staleža zaposlenih v podjetju.

Prvo hipotezo smo preverili z analizo variance dveh neodvisnih vzorcev: primerjali smo odstotek bolniškega staleža organizacij, ki imajo prevladujočo organizacijsko kulturo tipa trg, z odstotkom bolniškega sta- 
leža pri ostalih organizacijah (preglednica IO.I I). Na osnovi značilnostne ravni, kjer je vrednost večja od o,os $(p=0,134)$, potrjujemo ničelno hipotezo in trdimo, da ni statistično značilnih razlik med odstotkom bolniškega staleža pri organizacijah z organizacijsko kulturo tipa trg v primerjavi z odstotkom bolnišniškega staleža pri organizacijah, ki imajo drugačen tip organizacijske kulture (hierarhija, klan, adhokracija). Tudi primerjava indeksa onesposobljenosti pri organizacijah z organizacijsko kulturo trg in organizacijah $z$ drugimi tipi organizacijske kulture prinaša podoben rezultat $(\mathrm{p}=0, \mathrm{i} 74)$. Na podlagi teh rezultatov trdimo, da organizacijska kultura tipa trg nima vpliva na odstotek bolniškega staleža v slovenskih srednje velikih in velikih gospodarskih družbah.

Preglednica ı. I I: Primerjava variance odstotka bolniškega staleža organizacij z organizacijsko kulturo tipa trg z varianco odstotka bolniškega staleža organizacij z drugačnim tipom organizacijske kulture

\begin{tabular}{|c|c|c|c|c|c|}
\hline \multicolumn{6}{|c|}{ Statistične skupine } \\
\hline \multicolumn{2}{|c|}{ SKUPINA_TRG } & $\mathbf{N}$ & Povp. vrednost & St. odklon & St. napaka \\
\hline \multirow{2}{*}{ ODS_BS } &,$\infty \circ$ & 42 & 3,4484 & 1,46205 &, 22560 \\
\hline & 1,00 & 25 & 3,4240 & 1,87598 &, 37520 \\
\hline \multirow{2}{*}{$\mathrm{IO}$} &,$০ ০$ & 42 & 10,8320 & 4,70221 &, 72557 \\
\hline & 1,00 & 25 & 10,6827 & 5,85289 & $\mathrm{I}, \mathrm{I} 7058$ \\
\hline
\end{tabular}

\begin{tabular}{|c|c|c|c|c|c|c|c|c|c|c|}
\hline \multicolumn{11}{|c|}{ Test neodvisnih vzorcev } \\
\hline & & \multicolumn{2}{|c|}{$\begin{array}{l}\text { Levenov test enako- } \\
\text { stivarianc }\end{array}$} & \multicolumn{7}{|c|}{ T-test enakosti povprečij } \\
\hline & & \multirow[b]{2}{*}{ F } & \multirow[b]{2}{*}{$\mathrm{P}$} & \multirow[b]{2}{*}{$\mathrm{t}$} & \multirow[b]{2}{*}{ df } & \multirow[b]{2}{*}{$\mathrm{p}$ (2-str.) } & \multirow{2}{*}{$\begin{array}{c}\text { Raz- } \\
\text { lika med } \\
\text { povp. } \\
\text { vrednos- } \\
\text { tma }\end{array}$} & \multirow{2}{*}{$\begin{array}{l}\text { St. napa- } \\
\text { ka raz- } \\
\text { like }\end{array}$} & \multicolumn{2}{|c|}{$95 \%$ interval zaupanja } \\
\hline & & & & & & & & & $\begin{array}{c}\text { Spodnja } \\
\text { meja }\end{array}$ & $\begin{array}{l}\text { Zgornja } \\
\text { meja }\end{array}$ \\
\hline \multirow{2}{*}{ ODS_BS } & $\begin{array}{l}\text { Predpostavljene } \\
\text { enake variance }\end{array}$ & 2,306 & ,134 & .059 & 65 & .953 &, 02442 & ,41104 &.,- 79648 & .84532 \\
\hline & $\begin{array}{l}\text { Predpostavljene ra- } \\
\text { zlične variance }\end{array}$ & & & , 056 & 41,329 & .956 &, 02442 & , 43780 &,- 85952 & .90836 \\
\hline \multirow{2}{*}{ IO } & $\begin{array}{l}\text { Predpostavljene } \\
\text { enake variance }\end{array}$ & 1,886 &, 174 & ,I15 & 65 & 909 & 14930 & 1,30270 & $-2,45238$ & 2,75097 \\
\hline & $\begin{array}{l}\text { Predpostavljene ra- } \\
\text { zlične variance }\end{array}$ & & &, 108 & 42,327 & 914 & , 14930 & 1,37721 & $-2,62939$ & 2,92798 \\
\hline
\end{tabular}




\section{H2: Prevladujoča organizacijska kultura tipa klan ima signifi-}

kantno pozitiven vpliv na odstotek bolniškega staleža zaposlenih v podjetju.

Drugo hipotezo smo prav tako preverili z analizo variance dveh neodvisnih v vzorcev: primerjali smo odstotek bolniškega staleža organizacij, ki imajo prevladujočo organizacijsko kulturo tipa klan, z odstotkom bolniškega staleža pri ostalih organizacijah (preglednica IO.I2). Na osnovi značilnostne ravni, kjer je vrednost večja od o,o5 $(p=0,389)$, potrjujemo ničelno hipotezo in trdimo, da ni statistično značilnih razlik med odstotkom bolniškega staleža pri organizacijah z organizacijsko kulturo tipa klan v primerjavi z odstotkom bolnišniškega staleža pri organizacijah, ki imajo drugačen tip organizacijske kulture (hierarhija, trg, adhokracija). Tudi primerjava indeksa onesposobljenosti pri organizacijah z organizacijsko kulturo klan in organizacijah z drugimi tipi organizacijske kulture prinaša podoben rezultat $(\mathrm{p}=0,345)$. Na podlagi teh rezultatov trdimo, da organizacijska kultura tipa klan nima statistično značilnega vpliva na odstotek bolniškega staleža v slovenskih srednje velikih in velikih gospodarskih družbah.

Preglednica ı. I2: Primerjava variance odstotka bolniškega staleža organizacij z organizacijsko kulturo tipa klan z varianco odstotka bolniškega staleža organizacij z drugačnim tipom organizacijske kulture

\begin{tabular}{lccccc}
\multicolumn{5}{c}{ Statistične skupine } \\
& $\begin{array}{c}\text { SKUPINA_ } \\
\text { KLAN }\end{array}$ & N & Povp. vrednost & St. odklon & St. napaka \\
\cline { 2 - 6 } ODS_BS & 43 & 3,2902 & 1,68822 &, 25745 \\
\hline \multirow{2}{*}{ IO } & 1,00 & 24 & 3,7064 & 1,47061 &, 30019 \\
\hline & 1,00 & 43 & 10,3366 & 5,39327 &, 82247 \\
\hline
\end{tabular}




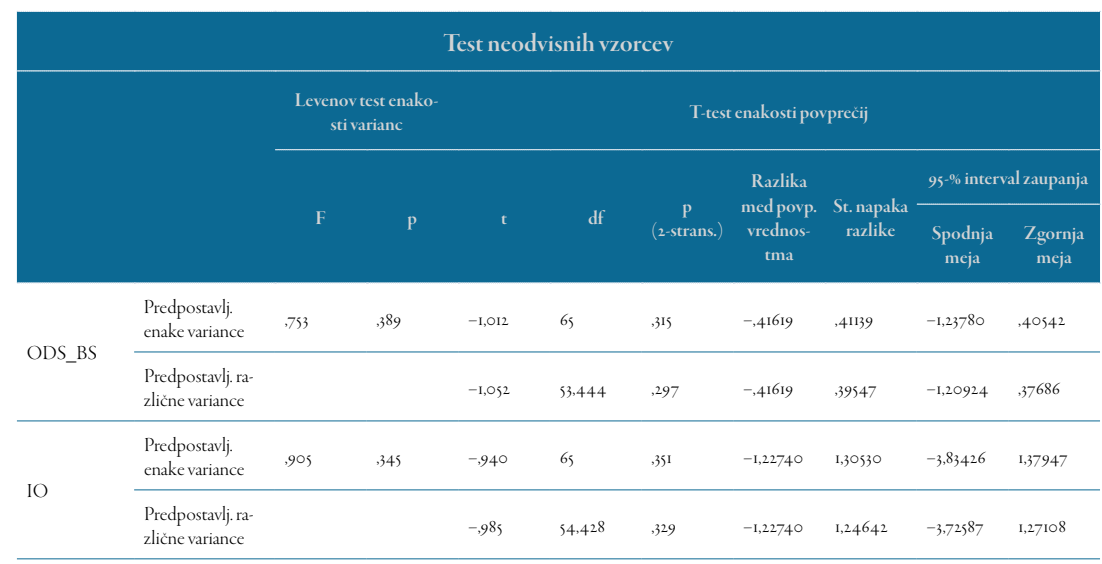

Sklepi iz raziskave

Z empirično raziskavo smo ugotovili, da tipi organizacijske kulture po Cameronu in Quinnu ne vplivajo na odstotek bolniškega staleža.

Pri izvedbi raziskave smo uporabili kvantitativno raziskavo, kot jo opredeljujejo Easterby-Smith, Thorpe in Lowe (2005). Kot pripomoček za pridobivanje podatkov in informacij smo uporabili vprašalnik. Populacijo v naši raziskavi predstavlja I.309 gospodarskih družb v Sloveniji z več kot 50 zaposlenimi. Nato smo po vrsti kontaktirali vsa ta podjetja in uspelo nam je dobiti 340 elektronskih naslovov vodij kadrovskih služb, ki smo jim smeli posredovati vprašalnik. Od 340 poslanih vprašalnikov smo dobili vrnjenih 67 vprašalnikov, za katere menimo, da posredujejo pravilne informacije. Od posredovanih vprašalnikov smo torej dobili vrnjenih I9,7 I \%, in to je v območju od is do $40 \%$ pričakovanega deleža vrnjenih vprašalnikov, kot ga navaja Flere (2000, I08), glede na vsa kontaktirana podjetja pa je v raziskavi sodelovalo 5, i 2 \% podjetij. Na tako pridobljenih podatkih in informacijah smo opravili statistično analizo s programskim paketom IBM SPSS.22. Osnovne izide smo predstavili tabelarično in opisno. Za ponazoritev pridobljenih podatkov smo uporabili deskriptivno statistiko, za preverjanje hipotez pa analizo variance (ANOVA). Statistično značilne rezultate smo obravnavali pri stopnji značilnosti o,05.

Cilj je bil preveriti naslednje hipoteze:

- $H_{\text {I }}$ Prevladujoča organizacijska kultura tipa trg ima signifikantno negativen vpliv na odstotek bolniškega staleža zaposlenih v podjetju. 
- H2: Prevladujoča organizacijska kultura tipa klan ima signifikantno pozitiven vpliv na odstotek bolniškega staleža zaposlenih v podjetju.

Hipotezo smo preverili z analizo variance, kjer smo primerjali aritmetično sredino odstotka bolniškega staleža organizacij z organizacijsko kulturo $\operatorname{trg} \mathrm{z}$ organizacijami, ki imajo drugačno prevladujočo organizacijsko kulturo, in organizacij z organizacijsko kulturo klan $s$ preostalimi organizacijami. Tudi F-test je pokazal, da ni statistično značilnih razlik v odstotku bolniškega staleža med skupinami podjetij glede na njihov tip organizacijske kulture in tako smo zavrnili obe postavljeni hipotezi. Ker ni statistično značilnih razlik v odstotku bolniškega staleža med skupinami podjetij z različnimi tipi prevladujočih organizacijskih kultur, ne moremo trditi, da imajo $\mathrm{v}$ podjetjih $\mathrm{z}$ organizacijsko kulturo tipa trg višji odstotek bolniškega staleža kot podjetja z drugim tipom organizacijske kulture; prav tako ne moremo trditi, da imajo v podjetjih z organizacijsko kulturo tipa klan nižji odstotek bolniškega staleža kot v podjetjih z drugačnim tipom organizacijske kulture. Na podlagi naše raziskave trdimo, da sta organizacijska kultura in odstotek bolniškega staleža povsem neodvisni spremenljivki.

\section{Predlogi za izboljšave}

\section{Ugotavljanje organizacijske kulture in njeno spreminjanje}

Pomembno je, da se organizacije zavedajo pomena organizacijske kulture za svojo uspešnost. Zato je potrebno identificiranje obstoječe organizacijske kulture in opredelitev željene organizacijske kulture ter nato spreminjanje obstoječe organizacijske kulture v željeno. Na absentizem vplivajo delovni pogoji, stres in zadovoljstvo zaposlenih, zato bi morale organizacije svojo organizacijsko kulturo razvijati v smeri, ki bi zaposlenim dajala večjo motivacijo za delo ter povzročala njihovo zadovoljstvo. Anketirani so delovno okolje v srednje velikih in velikih gospodarskih družbah ocenili kot zelo nadzorovano in strukturirano, sodelavci se morajo pri opravljanju svojega dela držati formalnih postopkov in pravil, zaposlene povezujejo formalna pravila. Najpomembnejše strateške usmeritve so učinkovitost, obdržati nadzor in delovati brez motenj. Glede na to, da so anketirane organizacije svoj kriterij uspešnosti v največji meri opredelile s trditvijo Organizacija opredeljuje svojo uspešnost na osnovi učinkovitosti. Ključno je sistematično načrtovanje dela in stem čim manjša poraba sredstev, sklepamo, da večji del slovenskih srednje velikih in velikih gospodarskih organizacij svojo uspešnost gradi na veliki delovni obreme- 
nitvi vsakega zaposlenega sodelavca, za minimalno zakonsko določeno plačilo. Orodja za doseganje učinkovitosti pa so nadzor in pravila. Hierarhična organizacijska kultura, ki je skupaj s klansko organizacijsko kulturo prevladujoča $\mathrm{v}$ slovenskih srednje velikih in velikih gospodarskih družbah, ni več primerna za današnje nestabilno gospodarsko okolje, ker zavira ustvarjalnost in povzroča nezadovoljstvo zaposlenih sodelavcev.

\section{Povečati pomen varnosti in zdravja pri delu}

Gspan in Jug $(1993,5)$ opozarjata, da v Sloveniji ni podatkov o tem, kolikšno ekonomsko škodo povzročajo poškodbe pri delu, bolezni zaradi dela in posledične invalidnosti. In ker nimamo podatkov o škodi zaradi slabega varstva pri delu, ne moremo objektivno oceniti, ali je vlaganje $v$ varnost in zdravje pri delu ekonomsko upravičeno ali ne.

Pridružujemo se mnenju avtorjev, da je vlaganje $\mathrm{v}$ varnost in zdravje pri delu v Sloveniji slabo načrtovano in velikokrat neučinkovito, pa tudi motiviranost za varnost in zdravje na delovnem mestu je nizka tako pri delodajalcih kot pri zaposlenih, predvsem zaradi nepoznavanja direktnih ekonomskih učinkov izvajanja posameznih ukrepov varstva pri delu. Zato bi bilo v Sloveniji potrebno uveljaviti enoten model ekonomskega vrednotenja učinkov ukrepov varnosti in zdravja pri delu, saj bi s tem lahko ugotovili, kateri ukrepi so učinkoviti in kje so učinkoviti ter ali so ekonomsko upravičeni.

\section{Raziskati vzroke za najpogostejše odsotnosti z dela in oblikovati ucinkovite preventivne ukrepe}

Glede na to, da smo na podlagi podatkov Inštituta za javno zdravje ugotovili, da je v Sloveniji največ odsotnosti zaradi poškodb in zastrupitev pri delu ter izven dela, lahko trdimo, da dosedanji način izvajanja izobraževanj in izpitov iz varnosti in zdravja pri delu ni učinkovit. Vsaka organizacija bo morala identificirati vse možne poškodbe in zastrupitve pri delu, ker se tveganja za poškodbe razlikujejo od organizacije do organizacije. Vrsta poškodb pri delu je v veliki meri odvisna od dejavnosti, ki jo organizacija izvaja, zato so posplošena izobraževanja o varnosti in zdravju pri delu premalo. Vsaka organizacija, bi morala vsaj enkrat letno organizirati poglobljeno izobraževanje o možnih poškodbah in zastrupitvah pri njenem delu, možnih načinih, kako lahko pride do posamezne poškodbe ali zastrupitve, ter vse možnih posledicah posamezne poškodbe in varnostnih ukrepih, s katerimi lahko preprečimo morebitne poškodbe. Zavod za zdravstveno zavarovanje Slovenije pa bi lahko organiziral kampanjo, ki bi opozarjala na nevarnosti in posledice poškodb pri delu doma, 
saj se ljudje v domačem okolju premalo zavedajo nevarnosti in zato so tudi manj pazljivi pri domačih opravilih.

Naslednji vzrok za bolniško odsotnost zaposlenih pa so bolezni mišično-kostnega sistema in vezivnega tkiva, ki pa je posledica sedečega dela. Nekatere organizacije že izvajajo nekajminutno telovadbo med delovnim časom, vendar pa so takšna podjetja redke izjeme. Menimo, da bi tovrstne aktivnosti lahko pripomogle k zmanjšanju bolezni mišično-kostnega sistema in vezivnega tkiva, vendar pa bi jih bilo potrebno zakonsko določiti, ker drugače ne bodo množično zaživele.

\section{Prispevek k znanosti}

Izvedli smo terensko raziskavo in ugotavljali vpliv tipa organizacijske kulture na zdravstveni absentizem v velikih in srednje velikih gospodarskih družbah v RS. Ker doslej tovrstne raziskave v RS še ni bilo, prinašajo rezultati naše raziskave nova znanja in spoznanja ter prispevajo k znanosti. Kot prvi v RS smo ugotovili, da tipi organizacijske kulture, hierarhija, trg, klan in adhokracija, na vplivajo statistično značilno na odstotek bolniškega staleža v velikih in srednje velikih gospodarskih družbah. Prav tako smo prišli do novih spoznanj tudi glede na dejavnosti, ki smo jih razdelili na izdelovalno in storitveno dejavnost: ugotovili smo, da dejavnost, ki jo opravljajo v gospodarskih družbah, ne vpliva statistično značilno na odstotek bolniškega staleža. Na podlagi teh ugotovitev smo mnenja, da rezultati raziskave prispevajo k novim teoretičnim, raziskovalnim ter praktičnim spoznanjem na področju managementa in organizacijske kulture ter njunega vpliva na zdravstveni absentizem.

\section{Predlogi za nadaljnje raziskovanje}

Navajamo naslednje predloge za nadaljnje raziskovanje:

- V empirično raziskavo je potrebno vključiti organizacije iz javnega sektorja npr. zdravstva, šolstva in sociale ter državne uprave.

- Organizacijsko kulturo in njen vpliv na zdravstveni absentizem $\mathrm{v}$ posamezni ustanovi naj bi ocenjevalo več sodelavcev, ker bi na ta način prišli do verodostojnejših informacij.

- Za pridobivanje podatkov o obstoječi organizacijski kulturi s pomočjo vprašalnika naj bi uporabili tudi vprašalnike drugih avtorjev in jih nato medsebojno primerjali.

- Pridobivanje podatkov o bolniški odsotnosti, na podlagi katerih se izračuna odstotek bolniškega staleža, naj izhaja iz uradno in 
formalno razpoložljivih evidenc pooblaščenih organizacij in ne iz osebne ocene.

- Raziskavo o stanju organizacijske kulture in njenega vpliva na zdravstveni absentizem naj bi ponovno opravili v času gospodarske rasti in rezultate primerjali z rezultati iz časa gospodarske krize.

\section{Literatura}

Cameron, K. S., in R. E. Quinn. 2006. Diagnosing and Changing Organizational Culture. Based on the Competing Values Framework. San Francisco: Jossey-Bass.

Easterby-Smith, M., R. Thorpe in A. Lowe. 2007. Raziskovanje v managementu. Koper: Univerza na Primorskem, Fakulteta za management.

Flere, S. 200o. Sociološka metodologija: temelji družboslovnega raziskovanja. Maribor: Pedagoška fakulteta, Univerza v Mariboru.

Gspan, P., in A. Jug. 1993. Ekonomski učinki varstva pri delu. Ljubljana: Zavod Republike Slovenije za varnost pri delu.

Kavčič, B. 20I I. Organizacijska kultura. Celje: Fakulteta za komercialne in poslovne vede.

Schein, E. H. I99I. »What Is Culture?« V Reframing Organizational Culture, ur. Peter J. Frost, Larry F. Moore, Meryl Reis Louis, Craig C. Lundberg in Joanne Martin, 243-53. London: Sage.

Strmec, M. 20I 2. Absentizem (preprečevanje, obvladovanje in zmanjševanje). Priročnik s primeri dobrih praks. Novo mesto: Gospodarska zbornica Dolenjske in Bele krajine.

Vučković, R. 2010. Obvladovanje zdravstvenega absentizma - izziv za družbo. Zdravstveni absentizem v Sloveniji. Zbornik primerov iz prakse I4 slovenskih podjetij. Ljubljana: Zavod za zdravstveno zavarovanje Slovenije. 



\title{
I I \\ Organizacijska klima \\ v slovenskih zdraviliščih
}

\author{
Nataša Kežman in Mirko Markič
}

Po pregledu raziskav in prispevkov zgoraj navedenih avtorjev smo ugotovili, da organizacijska klima vpliva na počutje zaposlenih. Počutje zaposlenih in njihovo zadovoljstvo pa pomembno vplivata na izide (uspešnost) njihovega dela in na odnos do strank. Neustrezna organizacijska klima pri zaposlenih povzroča slabo počutje, sodelavci so na delovnem mestu nezadovoljni, vse to pa se odraža v rezultatih njihovega dela in odnosu do strank. Zdraviliški turizem je ena izmed najstabilnejših pojavnih oblik turizma, saj je zdravljenje nujna potreba. Zdraviliški turizem definira skupnost odnosov in pojavov, ki s spremembo kraja bivanja spodbujajo, stabilizirajo in po potrebi vzpostavljajo telesno, duševno in socialno dobro počutje z uporabo zdravstvenih storitev (Gojčič 2005, 76).

$\mathrm{V}$ storitvenih organizacijah, kot so npr. zdraviliške, je zadovoljstvo gostov izjemnega pomena. Še tako kakovostna storitev, ki ni izvedena na pravilen način, ne prinese želenega rezultata - zadovoljstva gosta. Zavedali naj bi se, da se samo zadovoljni gost vrne, je ponovno pripravljen koristiti storitve zdravilišča, to pa organizaciji prinaša konkurenčno prednost (Gojčič 2005, 79).

Če se zavedamo, da so zaposleni v turizmu v neposrednem stiku z gosti (turisti), naj bi se zavedali tudi njihovega pomena za organizacijo. V vseh turističnih podjetjih, v katerih si prizadevajo za dvig uspešnosti, naj bi se zavedali, da kakovostno storitev lahko izvaja le primerno motivirano osebje. Manager naj bi ustvarjal ugodno vzdušje za sodelavce, kar je enako pomembno, kot ustvariti ugodno vzdušje za goste (Brezovec, 2000, I 19).

Pozitivno spodbujanje izrabljanja človeških virov poganja razvoj turizma, vpliva na kakovost storitev, omogoča premagovanje konkurence in 
posledično osvajanje trgov ter zagotavlja cvetočo prihodnost te dejavnosti (Florjančič in Jesenko, 1997, 65).

V slovenskih zdraviliško-turističnih centrih do sedaj še ni bilo opravljene raziskave o vplivu organizacijske klime na dodano vrednost, temveč se je vršni management pri prepoznavanju organizacijske klime zanašal zgolj na lastna znanja, izkušnje in občutke. Temeljni problem je, da še ni bilo opravljene raziskave o vplivu organizacijske klime na dodano vrednost $\mathrm{v}$ slovenskih zdraviliščih. Zaradi nujnosti celostnega razumevanja vpliva organizacijske klime na poslovno uspešnost želimo raziskati stanje $\mathrm{v}$ slovenskih zdraviliščih ter pomen in vpliv posameznih dejavnikov organizacijske klime glede na prihodek na zaposlenega $\mathrm{v}$ poslovanju izbranih slovenskih zdravilišč.

\section{Namen raziskave}

Namen kvantitativne raziskave je ugotoviti vpliv dimenzij organizacijske klime na donosnost $\mathrm{v}$ slovenskih zdraviliščih in nakazati možne rešitve za izboljšanje stanja.

\section{Metodologija}

Uporabili smo kvantitativno metodologijo raziskovanja; za pridobivanje podatkov in informacij o vplivu organizacijske klime na donosnost obravnavanih zdravilišč smo uporabili standardizirani vprašalnik SiOK.

Vprašalnik je vseboval:

- lestvico za oceno organizacijske klime - 69 vprašanj,

- oceno zadovoljstva z delom - i I vidikov zadovoljstva.

Vprašanja iz standardiziranega vprašalnika SIOK smo združili po apriornih dejavnikih ter jih v sami analizi v PSPP označili z okrajšavami, kot je prikazano v nadaljevanju:

I. Dejavnik organiziranosti

- Trditev št. 20. V organizaciji so pristojnosti in odgovornosti medsebojno uravnotežene na vseh nivojih - DO I

- Trditev št. 30. Odločitve naših vodij se sprejemajo pravočasno $\mathrm{DO}_{2}$

- Trditev št. 37. V naši organizaciji so zadolžitve jasno opredeljene $-\mathrm{DO}_{3}$

- Trditev št. 4r. Zaposleni razumemo svoj položaj v organizacijski shemi podjetja $-\mathrm{DO}_{4}$ 
- Trditev št. 52. Zaposleni imajo jasno predstavo o tem, kaj se od njih pričakuje pri delu - $\mathrm{DO}_{5}$

2. Strokovna usposobljenost in učenje

- Trditev št. 38. Organizacija zaposlenim nudi potrebno usposabljanje za dobro opravljanje dela - SUI

- Trditev št. 23. Zaposleni se učimo drug od drugega - SU2

- Trditev št. 58. Pri nas so zaposleni le ljudje, ki so usposobljeni za svoje delo $-\mathrm{SU}_{3}$

- Trditev št. 64. Sistem usposabljanja je dober - SU4

- Trditev št. 19. Pri usposabljanju se upoštevajo tudi želje zaposlenih - SUs

3. Odnos do kakovosti

- Trditev št. 9. Zaposleni po svoji moči prispevamo $\mathrm{k}$ doseganju standardov kakovosti - OKI

- Trditev št. I4. Druge sodelavce in oddelke obravnavamo kot svoje cenjene stranke - $\mathrm{OK}_{2}$

- Trditev št. 27. Naši oddelki imajo jasno zastavljene standarde in cilje kakovosti - $\mathrm{OK}_{3}$

- Trditev št. 43. Zaposleni se čutimo odgovorne za kakovost našega dela $-\mathrm{OK}_{4}$

- Trditev št. 6I. Kakovost dela in količina sta pri nas enako pomembni - OKs

4. Nagrajevanje

- Trditev št. 5. Uspešnost se praviloma vrednoti po dogovorjenih ciljih in strategijah $-\mathrm{N}_{\mathrm{I}}$

- Trditev št. 39. Tisti, ki so bolj obremenjeni z delom, so tudi ustrezno stimulirani - $\mathrm{N}_{2}$

- Trditev št. 24. Za slabo opravljeno delo sledi ustrezna graja oziroma kazen $-\mathrm{N}_{3}$

- Trditev št. 56. Zaposleni prejemamo plačo, ki je vsaj enakovredna ravni plač na tržišču - $\mathrm{N}_{4}$

- Trditev št. 62. Razmerja med plačami zaposlenih v podjetju so ustrezna $-\mathrm{N}_{5}$

5. Notranje komuniciranje in informiranje

- Trditev št. I 2. Vodstvo zaposlenim informacije posreduje na razumljiv način - KI 
- Trditev št. 33. O tem, kaj se dogaja v drugih enotah, dobimo dovolj informacij - $\mathrm{K}_{2}$

- Trditev št. 50. Naši nadrejeni nam dajejo dovolj informacij za dobro opravljanje našega dela $-\mathrm{K}_{3}$

- Trditev št. 57. Delovni sestanki so redni - $\mathrm{K}_{4}$

- Trditev št. 53. V naši organizaciji se vodje in sodelavci pogovarjamo sproščeno, prijateljsko in enakopravno - Ks

6. Notranji odnosi

- Trditev št. I6. V naši organizaciji cenimo delo svojih sodelavcev - NOI

- Trditev št. I 8. Konflikte rešujemo v skupno korist - $\mathrm{NO}_{2}$

- Trditev št. 36. Ljudje si medsebojno zaupajo - $\mathrm{NO}_{3}$

- Trditev št. 54. Odnosi med zaposlenimi so dobri - $\mathrm{NO}_{4}$

- Trditev št. 6o. V naši organizaciji med seboj mnogo bolj sodelujemo kot tekmujemo - NOs

7. Vodenje

- Trditev št. 3. Zaposleni smo samostojni pri opravljanju svojega dela - VI

- Trditev št. 7. Nadrejeni sprejemajo utemeljene pripombe na svoje delo - V2

- Trditev št. 2 I. Vodje se pogovarjajo s podrejenimi o rezultatih dela $-\mathrm{V}_{3}$

- Trditev št. 34. Vodje nas vzpodbujajo k sprejemanju večje odgovornosti za naše delo $-\mathrm{V}_{4}$

- Trditev št. 44. V naši organizaciji odpravljamo ukazovalno vedenje $-V_{5}$

\section{Pripadnost organizaciji}

- Trditev št. I. Naša ciljna organizacija ima velik ugled v okolju POI

- Trditev št. 17. Zaposleni ne bi zapustili organizacije, če bi se zaradi poslovnih težav znižala plača $-\mathrm{PO}_{2}$

- Trditev št. 32. Zaposlitev v naši organizaciji je varna oziroma zagotovljena $-\mathrm{PO}_{3}$

- Trditev št. 35. Ponosni smo, da smo zaposleni v naši organizaciji $-\mathrm{PO}_{4}$

- Trditev št. 55. Zaposleni zunaj organizacije pozitivno govorimo o njej - POs 
9. Poznavanje poslanstva in vizije ter ciljev

- Trditev št. 4. Naša organizacija ima jasno oblikovano poslanstvo - dolgoročni razlog obstoja in delovanja - PPI

- Trditev št. I I. Politika in cilji organizacije so jasni vsem zaposlenim - $\mathrm{PP}_{2}$

- Trditev št. 40. Pri postavljanju ciljev poleg vodij sodelujemo tudi ostali zaposleni $-\mathrm{PP}_{3}$

- Trditev št. 42. Cilje organizacije sprejemamo za svoje - PP4

Io. Motivacija in zavzetost

- Trditev št. I3. V naši organizaciji so postavljene zelo visoke zahteve glede delovne uspešnosti - $\mathrm{MZ}_{\mathrm{I}}$

- Trditev št. Is. V naši organizaciji vodje cenijo dobro opravljeno delo $-\mathrm{MZ}_{2}$

- Trditev št. 28. Zaposleni v naši organizaciji smo zavzeti za svoje delo $-\mathrm{MZ}_{3}$

- Trditev št. 59. V naši organizaciji smo pripravljeni na dodaten napor, kadar se to pri delu zahteva $-\mathrm{MZ}_{4}$

- Trditev št. 63. Dober delovni rezultat se v naši organizaciji hitro opazi in je pohvaljen - MZs

I I. Razvoj kariere

- Trditev št. 6. Kriteriji za napredovanje so jasni vsem zaposlenim - RKI

- Trditev št. 26. Naši vodilni vzgajajo svoje naslednike - RK2

- Trditev št. 3 I. Imamo sistem napredovanja, ki omogoča, da najboljši zasedejo najboljše položaje - $\mathrm{RK}_{3}$

- Trditev št. 45. Zaposleni na vseh nivojih imamo realne možnosti za napredovanje - $\mathrm{RK}_{4}$

- Trditev št. 49. Zaposleni v naši organizaciji smo zadovoljni z dosedanjim osebnim razvojem - RKs

I 2. Inovativnost, iniciativnost

- Trditev št. 8. Zaposleni v naši organizaciji se zavedamo nujnosti sprememb - II

- Trditev št. 22. V organizaciji se pričakuje, da predloge za izboljšave dajejo vsi - ne le naši vodje - I2

- Trditev št. 48. Zaposleni smo pripravljeni prevzeti tveganje za uveljavitev svojih vzpodbud $-\mathrm{I}_{3}$ 
- Trditev št. 46. Napake med preizkušanjem novih načrtov dela so v naši organizaciji sprejemljive $-\mathrm{I}_{4}$

- Trditev št. 5 r. Naše izdelke in storitve stalno izboljšujemo in posodabljamo - Is

13. Zadovoljstvo

- Trditev št. 65. Zadovoljstvo z delom - $Z_{\mathrm{I}}$

- Trditev št. 66. Zadovoljstvo z vodstvom organizacije - $Z_{2}$

- Trditev št. 67. Zadovoljstvo s sodelavci - $Z_{3}$

- Trditev št. 68. Zadovoljstvo z neposredno nadrejenimi - $Z_{4}$

- Trditev št. 69. Zadovoljstvo z možnostmi za napredovanje - Z5

- Trditev št. 70. Zadovoljstvo s plačo - Z6

- Trditev št. 7 I. Zadovoljstvo s statusom v organizaciji $-Z_{7}$

- Trditev št. 72. Zadovoljstvo z delovnimi pogoji (oprema, prostori) $-\mathrm{Z} 8$

- Trditev št. 73. Zadovoljstvo z možnostmi za izobraževanje - Z9

- Trditev št. 74. Zadovoljstvo s stalnostjo zaposlitve - $Z_{\text {IO }}$

- Trditev št. 75. Zadovoljstvo z delovnim časom - Z I I

Apriornim dimenzijam organizacijske klime so dodana še vprašanja o zadovoljstvu zaposlenih: s sodelavci, s stalnostjo zaposlitve, z delovnim časom, s samim delom, $\mathrm{z}$ neposredno nadrejenim, z možnostmi za izobraževanje, z delovnimi pogoji (oprema, prostori), s statusom v organizaciji, z vodstvom organizacije, $\mathrm{z}$ možnostmi napredovanja, s plačo.

Pri analizi smo upoštevali še prihodek na zaposlenega za posamezno zdravilišče v Sloveniji. S kazalnikom pokažemo, koliko skupnih prihodkov na zaposlenega so v organizaciji ustvarili v opazovanem letu. Večja vrednost kazalnika kaže na poslovno uspešnejšo organzacijo. Analizirali smo kazalnik prihodkov na zaposlenega, saj so nekatera zdravilišča v analiziranem obdobju izkazovala izgubo in bi to predstavljalo težavo v nadaljnji analizi s pomočjo programa SPSS.

Ker v raziskavi nismo želeli izpostavljati nobenega izmed analiziranih zdravilišč, jih ne predstavljamo z imeni, ampak smo vsakemu izmed izbranih zdravilišč namenili kodno oznako od A do M, kjer je A poslovno najuspešnejše zdravilišče, $M$ pa najmanj uspešno zdravilišče.

\section{Populacija in vzorec}

Vzorec je sestavljen iz I 3 zdraviliško-turističnih centrov v Republiki Sloveniji, ki izpolnjujejo zahtevane pogoje za pridobitev statusa državno verificiranega zdravilišča, kar jim omogoča vključevanje v javno zdravstveno 
mrežo Slovenije. Osnovni vzorec za anketiranje je zajemal 360 zaposlenih $\mathrm{v}$ izbranih zdraviliško-turističnih centrih, ki sodijo med največje v Sloveniji. Vseh zdraviliško-turističnih centrov, ki delujejo v Sloveniji in jih je po podatkih Slovenske turistične organizacije 17 , nismo mogli zajeti, saj bi to predstavljalo prevelik obseg za samo magistrsko delo. Obenem pa 360 zaposlenih predstavlja dovolj velik in reprezentativen vzorec. Pričakovana stopnja odzivnosti je bila $20-40 \%$ odgovorov tistih, ki jim je bil poslan vprašalnik (Flere 2000, I28).

\section{Postopki zbiranja podatkov}

Metodi zbiranja podatkov sta standardizirani anketni vprašalnik SiOK, ki je predstavljen v prilogi ter opisan $\mathrm{v}$ predhodnih poglavjih, in baza $\mathrm{iBON}^{\circledR}$ za leto $201 \mathrm{I}$, ki omogoča dostop do finančnih podatkov za slovenska naravna zdravilišča. Vprašalnik je bil poslan po e-pošti. Anketo smo opravljali v začetku leta 2013, od začetka januarja 2013 do sredine meseca februarja 2013. Med anketiranjem nismo naleteli na težave, anketirani so bili pripravljeni sodelovati v anketi, pri čemer smo jim zagotovili, da bo anketa anonimna in da se bodo rezultati uporabili samo za potrebe te magistrske naloge.

Meritev organizacijske klime je potekala skupinsko in anonimno, kar pomeni, da nas niso zanimali podatki na nivoju posameznika, ampak na nivoju celote oziroma posameznih organizacijskih enot. Znotraj podjetja smo s pomočjo enostavnega slučajnega vzorčenja zagotovili reprezentativen vzorec - organizacijo v malem glede na parametre raziskovanja (spol, starost, staž, nivo v organizaciji, stopnja izobrazbe).

\section{Rezultati raziskave}

\section{Demografske značilnosti anketiranih in razvrstitev slovenskih zdravilišč glede na pribodek na zaposlenega}

V raziskavi je sodelovalo 6r \% žensk in 39 \% moških. Največje število anketirancev spada v starostno skupino od 30 do 40 let, to je $48 \%$, temu sledi starostna skupina do 30 let, anketirancev je $23 \%$, najmanj anketirancev pa je starih nad so let, $8 \%$, iz česar lahko sklepamo, da so v slovenskih zdraviliščih naklonjeni zaposlovanju mladih. Med anketiranimi prevladujejo izvajalci nalog, delež teh je $82 \%$, ostali so enakomerno razdeljeni, 2 I \% je vršnih in srednjih managerjev, samostojnih strokovnih kadrov in operativnih vodij. Glede na čas zaposlitve v organizaciji prevladujejo tisti, ki imajo ro do 20 let delovne dobe, sledijo jim tisti z do 5 leti delovne dobe, najmanj pa je takih, ki imajo nad 20 let delovne dobe $\mathrm{v}$ izbranem 
zdravilišču. Glede na strokovno izobrazbo sicer prevladuje srednja strokovna izobrazba, vendar pa ni zanemarljiv delež niti tistih, ki imajo višjo ali visoko izobrazbo. Podatki so prikazani v preglednici i r.I. Prikazani so deleži za posamezeni dejavnik.

Preglednica i i.r: Demografske značilnosti anketiranih

\begin{tabular}{|c|c|c|c|c|c|c|c|c|c|}
\hline \multicolumn{2}{|c|}{ Starost } & \multicolumn{2}{|c|}{ Spol } & \multicolumn{2}{|c|}{ Nivo v organizaciji } & \multicolumn{2}{|c|}{ Delovni staž } & \multicolumn{2}{|c|}{ Strokovna izobrazba } \\
\hline do 30 let & $23,0 \%$ & moški & $39,0 \%$ & izvajalci & $82,0 \%$ & do 2 leti & $12,0 \%$ & $\begin{array}{l}\text { poklic- } \\
\text { našola ali } \\
\text { manj }\end{array}$ & $5,0 \%$ \\
\hline 30 do 40 let & $48,0 \%$ & ženski & $61,0 \%$ & $\begin{array}{l}\text { srednji in } \\
\text { vršni man- } \\
\text { agerji }\end{array}$ & $7,0 \%$ & 2 do 5 let & $28,0 \%$ & srednja šola & $48,0 \%$ \\
\hline 40 do 50 let & $21,0 \%$ & & & $\begin{array}{l}\text { samosto- } \\
\text { jni strokovni } \\
\text { sodelavci }\end{array}$ & $6,0 \%$ & 5 do ro let & $10,0 \%$ & višja śola & $18,0 \%$ \\
\hline nad so let & $8,0 \%$ & & & $\begin{array}{l}\text { operativni } \\
\text { vodje }\end{array}$ & $8,0 \%$ & 10 do 20 let & $44,0 \%$ & visoka ali več & $29,0 \%$ \\
\hline
\end{tabular}

Preglednica I 1.2: Razvrstitev slovenskih zdravilišč glede na prihodek na zaposlenega

\begin{tabular}{lccc} 
Zdraviliščc & Čsti prihodki (vEUR) & $\begin{array}{c}\text { Povprečno št. Zaposlenih } \\
\text { A }\end{array}$ & $\begin{array}{c}\text { Prihodek na zaposlenega } \\
\text { (v EUR) }\end{array}$ \\
\hline B & 17684047 & 206 & $85.844,88$ \\
\hline C & 32784592 & 460 & $71.270,85$ \\
\hline D & 10857674 & 172 & $63.126,01$ \\
\hline E & 7914589 & 129 & $61.353,40$ \\
\hline F & 7503467 & 123 & $61.003,79$ \\
\hline G & 25052092 & 440 & $56.936,57$ \\
\hline H & 11581363 & 213 & $54.372,59$ \\
\hline I & 31308151 & 614 & $50.990,47$ \\
\hline$J$ & 18119531 & 381 & $47.557,82$ \\
\hline K & 7931301 & 167 & $47.492,82$ \\
\hline L & 20122352 & 461 & $43.649,35$ \\
\hline M & 4486840 & 105 & $42.731,80$ \\
\hline Povprečje & 5811150 & 152 & $38.231,25$ \\
\hline & & & $55.537,58$ \\
\hline
\end{tabular}

Vir: iBON"2013. 
Iz preglednice I I.2 vidimo, da imajo $\mathrm{v}$ šestih slovenskih zdraviliščih prihodek na zaposlenega večji od povprečja vseh slovenskih zdravilišč, v sedmih zdraviliščih pa je prihodek na zaposlenega manjši od povprečja. $\mathrm{V}$ najmanj uspešnem slovenskem zdravilišču je prihodek na zaposlenega več kot za enkrat manjši kot v najboljših dveh.

\section{Analiza dejavnikov organizacijske klime}

Podatke smo analizirali s pomočjo računalniških orodij Excel in PSPP, ki je prostokodna različica programa SPSS in je brezplačno dostopna vsakomur. Omogoča ista opravila kot verzija SPSS. Najprej smo meritve iz vprašalnika razvrstili glede na število apriornih dimenzij (kategorij) klime skladno z raziskavo $\mathrm{SiOK}$, in sicer: organiziranost, strokovna usposobljenost in učenje, odnos do kakovosti, nagrajevanje, notranje komuniciranje in informiranje, notranji odnosi, vodenje, pripadnost organizaciji, poznavanje poslanstva in vizije ter ciljev, motivacija in zavzetost, razvoj kariere, inovativnost in iniciativnost, zadovoljstvo pri delu kot posebna kategorija z enajstimi vprašanji, ki meri zadovoljstvo posameznika $\mathrm{z}$ različnimi vidiki njegovega dela.

$\mathrm{Z}$ razvrščanjem in urejanjem izidov meritev smo oblikovali frekvenčne porazdelitve meritev tako po posameznih vprašanjih kot skupno po apriornih kategorijah organizacijske klime. S frekvenčno porazdelitvijo smo prikazali pogostnost vrednosti, ki jih je zavzela posamezna ocena.

Najvišje povprečne ocene pri vseh dejavnikih smo dobili v zdraviliščih, pri katerih smo ugotovili, da imajo največji povprečni letni prihodek na zaposlenega. $V$ primeru analize dejavnika organiziranosti vidimo, da so najboljše ocene v povprečju dali zaposleni v Termah A in Termah B.

\section{Organiziranost}

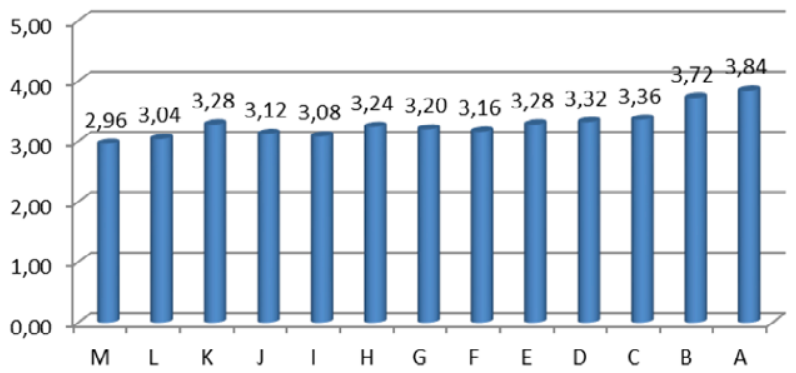


$\mathrm{V}$ primeru dejavnika strokovnega usposabljanja in izobraževanja so najboljše ocene prisodili zaposleni v Termah B, ki jim zopet sledijo zaposleni iz Term A. Zaposleni v Termah $M$ in Termah L najslabše ocenjujejo te dejavnike.

\section{Strokovna usposobljenost, učenje}

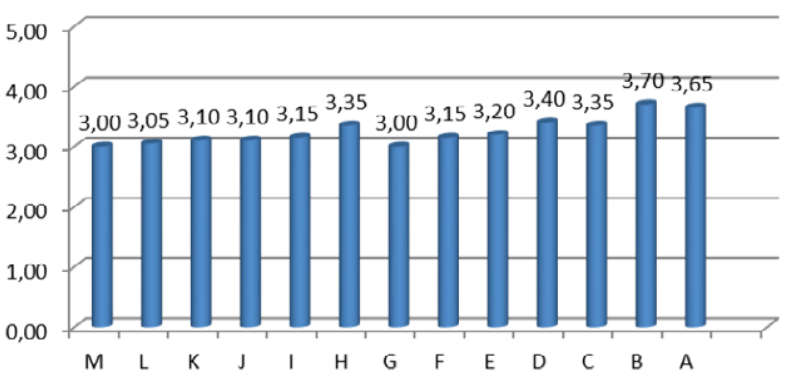

Slika I I.2: Strokovna usposobljenost in učenje

Tudi v primeru odnosa do kakovosti sta na prvih mestih Terme B in Terme A, pri čemer pa moramo poudariti, da so v tem primeru srednje vrednosti nekoliko bolj izenačene, nobeno izmed zdravilišč ne izstopa posebej. Najslabšo oceno so pri tem dejavniku prisodili zaposleni v Termah G.

\section{Odnos do kakovosti}

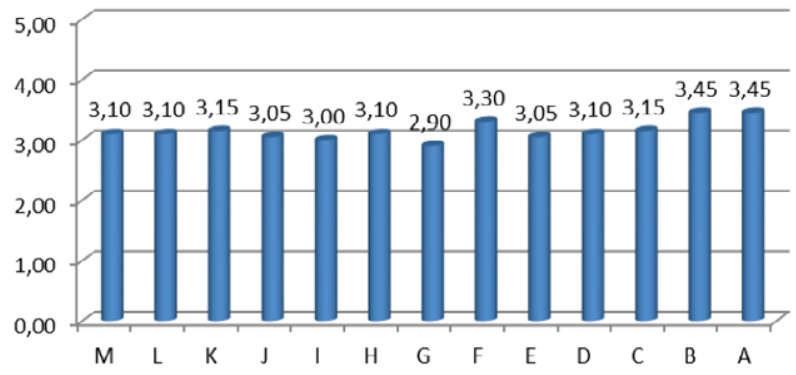

Slika I 1.3: Odnos do kakovosti

S sistemom nagrajevanja so najbolj zadovoljni zaposleni v Termah B, ki jim sledijo zaposleni v Termah A. Preostala zdravilišča so pri tem de- 
javniku nekako izenačena, nobeno ne izstopa niti v pozitivnem niti v negativnem smislu.

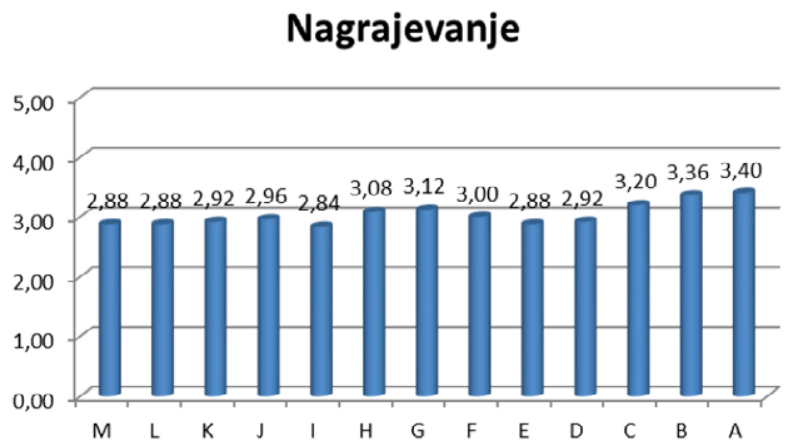

Slika i 1.4: Nagrajevanje

Prav tako so s področjem komuniciranja najbolj zadovoljni zaposleni v Termah B, zopet pa so na drugem mestu Terme A. Najslabše to področje ocenjujejo zaposleni v Termah G, ki jim sledijo Terme J.

Notranje komuniciranje

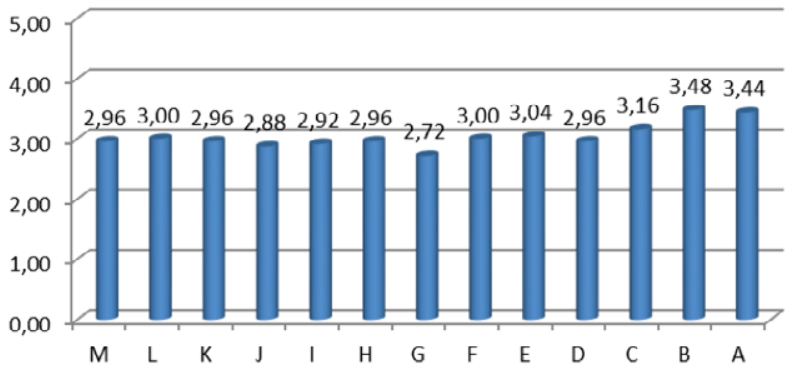

Slika i I.5: Notranje komuniciranje

Kot že v nekaj primerih pred tem, tudi notranje odnose najboljše ocenjujejo zaposleni v Termah B, ki jim sledijo zaposleni iz Term A. Lahko pa rečemo, da so vsi anketirani dokaj zadovoljni s tem področjem, saj nobeno izmed zdravilišč ne izstopa $\mathrm{v}$ negativnem smislu, torej so povprečne ocene enake ali preko 3 . 


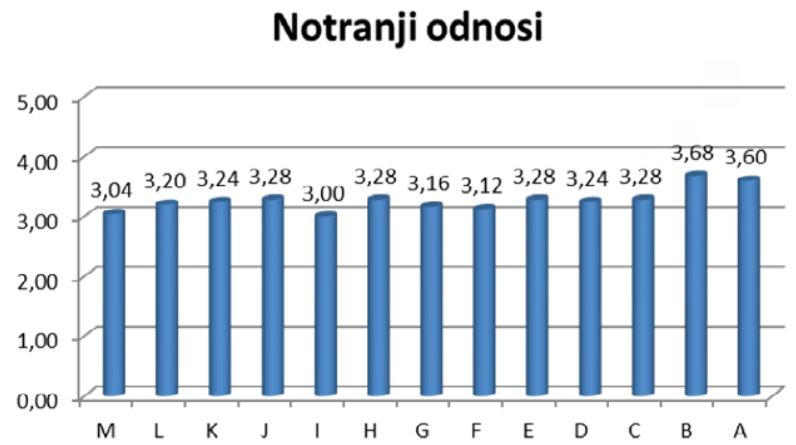

Slika 1 1.6: Notranji odnosi

Tudi s področjem vodenja so anketirani očitno kar zadovoljni, saj je tudi v tem primeru povprečna ocena preko 3 . Pri čemer pa so $s$ tem področjem najbolj zadovoljni zaposleni $\mathrm{v}$ dveh najuspešnejših zdraviliščih glede na prihodek na zaposlenega, in sicer v Termah A in B.

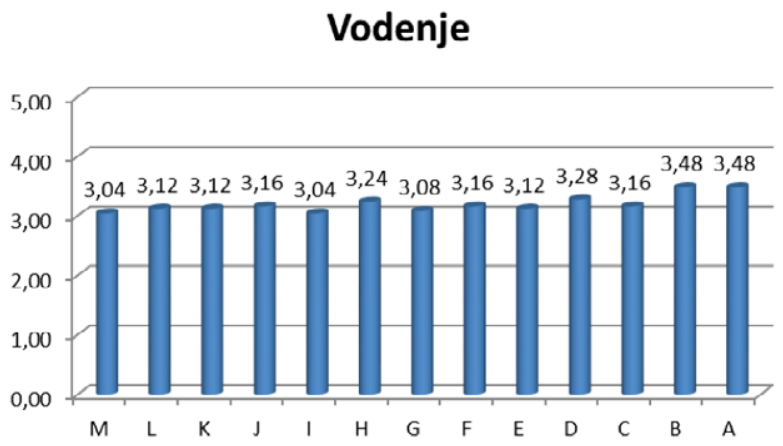

Slika i 1.7: Vodenje

Pripadnost organizaciji je po našem mnenju kar pomemben dejavnik $\mathrm{v}$ organizacijski klimi in kulturi. Glede na izmerjene ocene vidimo, da so anketirani s tem področjem dokaj zadovoljni. Kljub temu da nekoliko izstopata oceni za Terme A in Terme B, lahko rečemo, da so tudi ostali dokaj zadovoljni. 


\section{Pripadnost organizaciji}

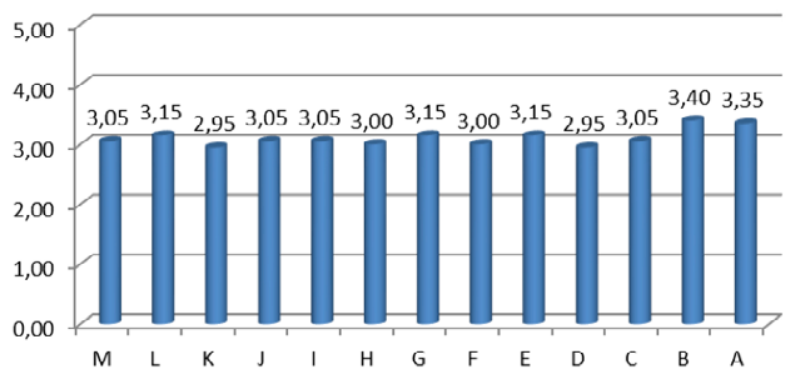

Slika i 1.8: Pripadnost organizaciji

$S$ cilji, vizijo in poslanstvom organizacije so najbolj seznanjeni zaposleni v Termah B, dokaj blizu pa so tudi zaposleni iz Term A. Nekoliko manj pa so $s$ tem seznanjeni zaposleni v ostalih slovenskih naravnih zdraviliščih, ki ta dejavnik ocenjujejo s povprečno oceno manj kot 3 .

\section{Poznavanje ciljev, vizije, poslanstva}

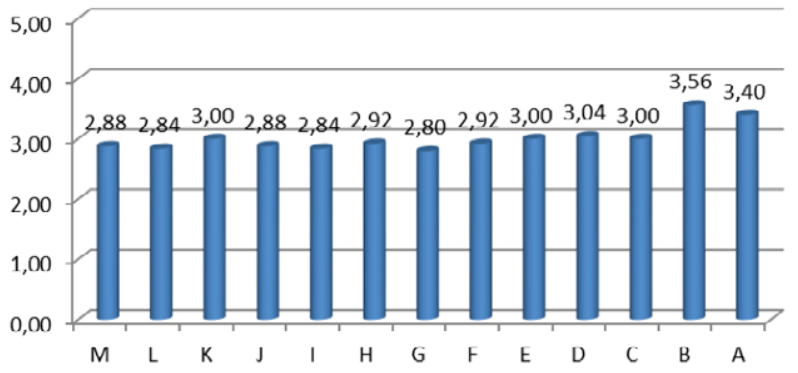

Slika I .9: Poznavanje vizije in poslanstva ter smotrov in ciljev organizacije

Zaposleni so v vseh zdraviliščih dokaj motivirani za dobro opravljanje dela, saj ga v vseh primerih ocenjujejo preko 3 . Najvišja povprečna ocena znaša 3,6 , prisodili pa so jo zaposleni iz Term B. 
Motivacija, zavzetost

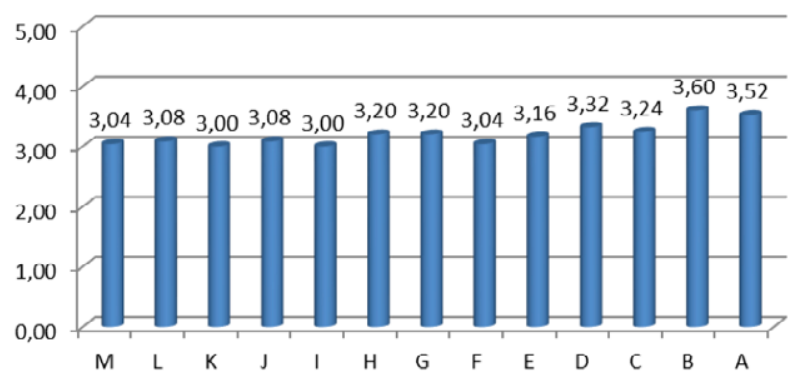

Slika I 1.10: Motivacija in zavzetost zaposlenih

$\mathrm{Z}$ razvojem kariere so najzadovoljnejši v Termah $\mathrm{A}$, so pa s tem področjem zadovoljni tudi $\mathrm{v}$ ostalih slovenskih zdraviliščih, ki dosegajo dobre rezultate glede na prihodek na zaposlenega.

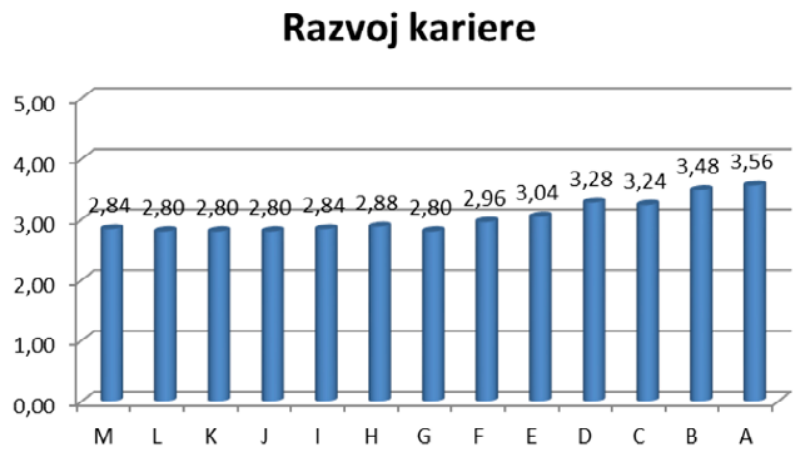

Slika I I. I : Razvoj kariere v organizaciji

$\mathrm{Na}$ koncu smo z vprašalnikom SIOK preverjali tudi splošno zadovoljstvo zaposlenih s posameznim dejavnikom zadovoljstva - vseh dejavnikov je i . Najvišjo povprečno oceno vseh dejavnikov so prisodili zaposleni v Termah A, blizu 4, sledijo jim zaposleni v Termah B. Glede na povprečne ocene vidimo, da nihče izmed anketiranih ni posebej nezadovoljen. 


\section{Zadovoljstvo}

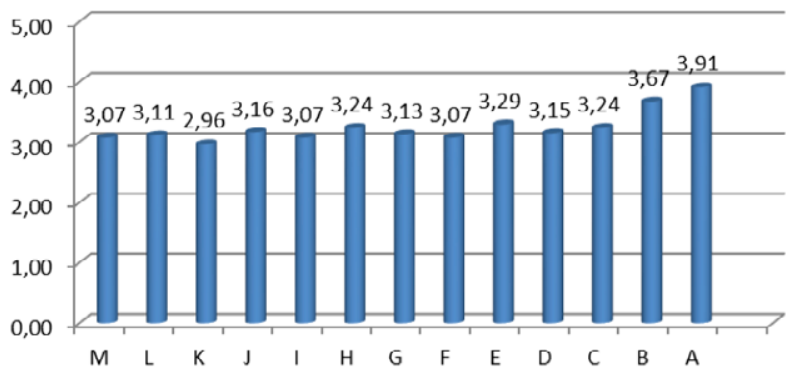

Slika i I.r 2: Zadovoljstvo zaposlenih

\section{Analiza odvisnosti donosnosti podjetja od dejavnikov organizacijske}

\section{klime}

Odvisnost donosnosti organizacije, $v$ našem primeru prihodkov na zaposlenega, od posameznih analiziranih dejavnikov organizacijske klime, ki smo jo merili, smo analizirali s pomočjo nekaterih statistik. Merili smo korelacijski koeficient med dejavniki organizacijske klime kot neodvisne spremenljivke in prihodki na zaposlenega kot odvisne spremenljivke.

Pearsonov koeficient korelacije je matematična in statistična številska mera, ki predstavlja velikost linearne povezanosti spremenljivk $\mathrm{X}$ in $\mathrm{Y}$, merjenih na istem predmetu preučevanja. Koeficient je definiran kot vsota vseh produktov standardnih odklonov obeh vrednosti v razmerju $s$ stopnjami prostosti oziroma kot razmerje med kovarianco in produktom obeh standardnih odklonov.

Pearsonov koeficient $\circ$ označuje ničelni vpliv ene spremenljivke na drugo, koeficient I označuje popolni vpliv ene spremenljivke na drugo. Vrednost koeficienta:

- $0,00-$ ni povezanosti,

- 0,0I-0,19 - neznatna povezanost,

- 0,20-0,39- nizka/šibka povezanost,

- 0,40-0,69- srednja/zmerna povezanost,

- 0,70-0,89- visoka/močna povezanost,

- 0,90-0,99- zelo visoka/zelo močna povezanost,

- $\quad$ 1,00 - popolna (funkcijska) povezanost.

Izračunali smo Pearsonov koeficient med vsemi spremenljivkami. Prikazani so v preglednici v prilogi. Na tem mestu pa posebej opozarjamo na tiste, pri katerih je Pearsonov koeficient korelacije najvišji. Pri teh 
znaša korelacijski koeficient več kot 0,55 in pomeni zmerno povezanost. Pri preostalih je ta koeficient med nižjimi. To so dejavniki:

- Dejavnik organizacije - DO:

o V organizaciji so pristojnosti in odgovornosti uravnotežene na vseh nivojih - DO I

o Zaposleni imamo jasno predstavo o tem, kaj se od nas pričakuje - DOs

- Strokovno usposabljanje in učenje - SU

o Zaposleni se učimo drug od drugega - $\mathrm{SU}_{2}$

- Nagrajevanje - N:

o Razmerja med plačami zaposlenih so ustrezna - $\mathrm{N}_{5}$

- Motivacija in zavzetost - MZ:

o $\quad \mathrm{V}$ naši organizaciji vodje cenijo dobro opravljeno delo - $\mathrm{MZ}_{2}$

234 - Razvoj kariere - RK:

o Zaposleni v naši organizaciji smo zadovoljni z dosedanjim osebnim razvojem $-\mathrm{RK}$ s

- Inovativnost - I

o Zaposleni smo pripravljeni prevzeti tveganje za uveljavitev svojih vzpodbud - $\mathrm{I}_{3}$

- Zadovoljstvo - Z:

o Zadovoljstvo z neposredno nadrejenimi $-Z_{4}$

o Zadovoljstvo s statusom v organizaciji $-Z_{7}$

o Zadovoljstvo z možnostmi za izobraževanje $-Z_{9}$

Preglednica I 1.3: Korelacija med prihodki na zaposlenega in dejavniki organizacijske klime

\section{prihodek}

\begin{tabular}{|c|c|c|}
\hline prihodek & Pearsonova soodnosnost & I \\
\hline & \multicolumn{2}{|l|}{ Sig. (I-tailed) } \\
\hline & $\mathrm{N}$ & 66 \\
\hline \multirow[t]{3}{*}{$\mathrm{DO}_{\mathrm{I}}$} & Pearsonova soodnosnost & 0,63 \\
\hline & Sig. (I-tailed) & $0,0 \circ$ \\
\hline & $\mathrm{N}$ & 66 \\
\hline \multirow[t]{3}{*}{$\mathrm{DO}_{5}$} & Pearsonova soodnosnost & 0,59 \\
\hline & Sig. (I-tailed) & ০,০০ \\
\hline & $\mathrm{N}$ & 66 \\
\hline \multirow[t]{2}{*}{$\mathrm{SU}_{\mathrm{I}}$} & Pearsonova soodnosnost & 0,47 \\
\hline & Sig. (I-tailed) & 0,00 \\
\hline
\end{tabular}




\begin{tabular}{|c|c|c|}
\hline & & prihodek \\
\hline & $\mathrm{N}$ & 66 \\
\hline \multirow[t]{3}{*}{$\mathrm{SU}_{2}$} & Pearsonova soodnosnost & 0,57 \\
\hline & Sig. (I-tailed) & 0,00 \\
\hline & $\mathrm{N}$ & 66 \\
\hline \multirow[t]{3}{*}{$\mathrm{N}_{5}$} & Pearsonova soodnosnost & 0,57 \\
\hline & Sig. (I-tailed) & 0,00 \\
\hline & $\mathrm{N}$ & 66 \\
\hline \multirow[t]{3}{*}{$\mathrm{MZ}_{2}$} & Pearsonova soodnosnost & 0,59 \\
\hline & Sig. (I-tailed) & ০,০০ \\
\hline & $\mathrm{N}$ & 66 \\
\hline \multirow[t]{3}{*}{$\mathrm{RK}_{5}$} & Pearsonova soodnosnost & 0,62 \\
\hline & Sig. (I-tailed) & 0,00 \\
\hline & $\mathrm{N}$ & 66 \\
\hline \multirow[t]{3}{*}{$\mathrm{I}_{3}$} & Pearsonova soodnosnost & 0,57 \\
\hline & Sig. (I-tailed) & 0,00 \\
\hline & $\mathrm{N}$ & 66 \\
\hline \multirow[t]{3}{*}{$\mathrm{Z}_{4}$} & Pearsonova soodnosnost & 0,57 \\
\hline & Sig. (I-tailed) & 0,00 \\
\hline & $\mathrm{N}$ & 66 \\
\hline \multirow[t]{3}{*}{$\mathrm{Z}_{7}$} & Pearsonova soodnosnost & 0,65 \\
\hline & Sig. (I-tailed) & 0,00 \\
\hline & $\mathrm{N}$ & 66 \\
\hline \multirow[t]{3}{*}{$\mathrm{Z}_{9}$} & Pearsonova soodnosnost & 0,59 \\
\hline & Sig. (I-tailed) & 0,00 \\
\hline & $\mathrm{N}$ & 66 \\
\hline
\end{tabular}

ANOVA ali analiza variance je $\mathrm{v}$ raziskavah pogosto uporabljena statistična metoda. Je splošno ime za metode, ki primerjajo pojasnjeno variabilnost z nepojasnjeno. Če je pojasnjena variabilnost dovolj velika v primerjavi z nepojasnjeno, lahko zaključimo, da ima tisto, kar pojasnjuje, nek vpliv na obravnavano odvisno spremenljivko. 
Organizacijska kultura in organizacijska klima

Preglednica i I .4: Analiza variance ANOVA

\begin{tabular}{|c|c|c|c|c|c|c|}
\hline & & Vsota kvadratov & $\begin{array}{l}\text { Prostostna } \\
\text { stopnja }\end{array}$ & Vrednost kvadrata & F & Pomembnost \\
\hline \multirow[t]{3}{*}{$\mathrm{DO}_{\mathrm{I}}$} & Med skupinami & 24,39 & 12 & 2,03 & 4,54 & ০,০০ \\
\hline & Zunaj skupin & 23,73 & 53 & 0,45 & & \\
\hline & Skupaj & 48,12 & 65 & & & \\
\hline \multirow[t]{3}{*}{$\mathrm{DO}_{5}$} & Med skupinami & 6,52 & 12 & 0,54 & 4,15 & ০,০০ \\
\hline & Zunaj skupin & 6,93 & 53 & 0,13 & & \\
\hline & Skupaj & 13,45 & 65 & & & \\
\hline \multirow[t]{3}{*}{$S U_{I}$} & Med skupinami & 4,97 & 12 & $0,4 \mathrm{I}$ & 7,84 & ০,০০ \\
\hline & Zunaj skupin & 2,8 & 53 & 0,05 & & \\
\hline & Skupaj & 7,77 & 65 & & & \\
\hline \multirow[t]{3}{*}{$\mathrm{SU}_{2}$} & Med skupinami & 14,08 & 12 & 1,17 & 3,51 & ০,০০ \\
\hline & Zunaj skupin & 17,73 & 53 & 0,33 & & \\
\hline & Skupaj & 31,82 & 65 & & & \\
\hline \multirow[t]{3}{*}{$\mathrm{N}_{5}$} & Med skupinami & 2,52 & 12 & $0,2 \mathrm{I}$ & 3,45 & 0,00 \\
\hline & Zunaj skupin & 3,23 & 53 & 0,06 & & \\
\hline & Skupaj & 5,76 & 65 & & & \\
\hline \multirow[t]{3}{*}{$\mathrm{MZ}_{2}$} & Med skupinami & 1,96 & 12 & 0,16 & 0,6 & 0,83 \\
\hline & Zunaj skupin & 2,83 & 53 & 0,05 & & \\
\hline & Skupaj & 6,62 & 65 & & & \\
\hline \multirow[t]{3}{*}{$\mathrm{RK}_{5}$} & Med skupinami & 24,09 & 12 & $2, \mathrm{OI}$ & 6,86 & 0,00 \\
\hline & Zunaj skupin & 15,5 & 53 & 0,29 & & \\
\hline & Skupaj & 39,59 & 65 & & & \\
\hline \multirow[t]{3}{*}{$\mathrm{I}_{3}$} & Med skupinami & 3,43 & 12 & 0,29 & 4,21 & 0,00 \\
\hline & Zunaj skupin & 3,6 & 53 & 0,07 & & \\
\hline & Skupaj & 7,03 & 65 & & & \\
\hline \multirow[t]{3}{*}{$\mathrm{Z}_{4}$} & Med skupinami & 4,26 & 12 & 0,35 & 4,7 & ০,০০ \\
\hline & Zunaj skupin & 4 & 53 & 0,08 & & \\
\hline & Skupaj & 8,26 & 65 & & & \\
\hline \multirow[t]{3}{*}{$\mathrm{Z}_{7}$} & Med skupinami & 5,83 & 12 & 0,49 & 8,05 & 0,00 \\
\hline & Zunaj skupin & 3,2 & 53 & 0,06 & & \\
\hline & Skupaj & 9,03 & 65 & & & \\
\hline
\end{tabular}




\begin{tabular}{ccccccc} 
& Vsota kvadratov & $\begin{array}{c}\text { Prostostna } \\
\text { stopnja }\end{array}$ & Vrednost kvadrata & F & Pomembnost \\
\hline Z9 & Med skupinami & 6,49 & 12 & 0,54 & 3,75 & 0,00 \\
\hline Zunaj skupin & 7,63 & 53 & 0,14 & \\
\hline Skupaj & 14,12 & 65 & & \\
\hline
\end{tabular}

Iz preglednice I I. 4 je razvidno:

- DOr: Ocena pojasnjene variance znaša 2,03. Ocena nepojasnjene variance znaša 0,45 . Pojasnjena varianca je dovolj velika v primerjavi z nepojasnjeno, zato lahko zaključimo, da ima neodvisna spremenljivka vpliv na odvisno spremenljivko, v našem primeru prihodke na zaposlene.

- DO5: Ocena pojasnjene variance znaša 0,54. Ocena nepojasnjene variance znaša 0,13 . Pojasnjena varianca je dovolj velika v primerjavi z nepojasnjeno, zato lahko zaključimo, da ima neodvisna spremenljivka vpliv na odvisno spremenljivko, v našem primeru prihodke na zaposlene.

- SUI: Ocena pojasnjene variance znaša o,4I. Ocena nepojasnjene variance znaša 0,05 . Pojasnjena varianca je dovolj velika v primerjavi z nepojasnjeno, zato lahko zaključimo, da ima neodvisna spremenljivka vpliv na odvisno spremenljivko, v našem primeru prihodke na zaposlene.

- SU2: Ocena pojasnjene variance znaša I,I7. Ocena nepojasnjene variance znaša 0,33 . Pojasnjena varianca je dovolj velika v primerjavi z nepojasnjeno, zato lahko zaključimo, da ima neodvisna spremenljivka vpliv na odvisno spremenljivko, $v$ našem primeru prihodke na zaposlene.

- N5: Ocena pojasnjene variance znaša o,2r. Ocena nepojasnjene variance znaša o,o6. Pojasnjena varianca je dovolj velika v primerjavi z nepojasnjeno, zato lahko zaključimo, da ima neodvisna spremenljivka vpliv na odvisno spremenljivko, v našem primeru prihodke na zaposlene.

- MZ2: Ocena pojasnjene variance znaša o,16. Ocena nepojasnjene variance znaša o,05. Pojasnjena varianca je dovolj velika v primerjavi z nepojasnjeno, zato lahko zaključimo, da ima neodvisna spremenljivka vpliv na odvisno spremenljivko, $v$ našem primeru prihodke na zaposlene.

- RK5: Ocena pojasnjene variance znaša 2,or. Ocena nepojasnjene variance znaša o,29. Pojasnjena varianca je dovolj velika v pri- 
merjavi z nepojasnjeno, zato lahko zaključimo, da ima neodvisna spremenljivka vpliv na odvisno spremenljivko, v našem primeru prihodke na zaposlene.

- I3: Ocena pojasnjene variance znaša 0,29. Ocena nepojasnjene variance znaša o,07. Pojasnjena varianca je dovolj velika v primerjavi z nepojasnjeno, zato lahko zaključimo, da ima neodvisna spremenljivka vpliv na odvisno spremenljivko, v našem primeru prihodke na zaposlene.

- Z4: Ocena pojasnjene variance znaša o,35. Ocena nepojasnjene variance znaša $\circ, 08$. Pojasnjena varianca je dovolj velika v primerjavi z nepojasnjeno, zato lahko zaključimo, da ima neodvisna spremenljivka vpliv na odvisno spremenljivko, v našem primeru prihodke na zaposlene.

- $Z_{7}$ : Ocena pojasnjene variance znaša o,49. Ocena nepojasnjene variance znaša o,o6. Pojasnjena varianca je dovolj velika v primerjavi z nepojasnjeno, zato lahko zaključimo, da ima neodvisna spremenljivka vpliv na odvisno spremenljivko, v našem primeru prihodke na zaposlene.

- Z9: Ocena pojasnjene variance znaša o,54. Ocena nepojasnjene variance znaša o, I 4. Pojasnjena varianca je dovolj velika v primerjavi z nepojasnjeno, zato lahko zaključimo, da ima neodvisna spremenljivka vpliv na odvisno spremenljivko, $v$ našem primeru prihodke na zaposlene.

Primerjava izidov pokaže določena odstopanja tako v pozitivni kot v negativni smeri. Večja pozitivna odstopanja se kažejo v kategorijah nagrajevanje, vodenje, motivacija in zavzetost, negativne pa so kategorije notranji odnosi, pripadnost organizaciji, odnos do kakovosti, razvoj kariere, strokovna usposobljenost, učenje ter poznavanje poslanstva in vizije ter ciljev.

Odnos do kakovosti je po ocenah anketiranih ena izmed najvišje ocenjenih kategorij klime. Kategorijo motivacija in zavzetost so anketirani ocenili precej visoko, saj je poleg odnosa do kakovosti najvišje ocenjena kategorija organizacijske klime. Kategorija inovativnost in iniciativnost je med tremi najbolje ocenjenimi kategorijami organizacijske klime. Kategorija vodenje je med srednje ocenjenimi kategorijami. Kategorija pripadnost organizaciji je med srednje ocenjenimi. Kategorija organiziranost je med srednje ocenjenimi. Kategorija strokovna usposobljenost in učenje je po višini ocen organizacijske klime v sredini. Tudi kategorija poznavanje poslanstva in vizije ter ciljev je med srednje ocenjenimi kategorijami. Kategorija notranji odnosi je med nižje ocenjenimi kategorijami. 
Anketirani so kategorijo notranje komuniciranje in informiranje ocenili nizko. Razvoj kariere so anketirani ocenili kot najnižjo med dvanajstimi kategorijami. Kategorija zadovoljstvo pri delu je bila ocenjena visoko.

\section{Analiza hipotez}

$H_{I}$ : Notranji odnosi imajo signifikantno pozitiven vpliv na donosnost $v$ slovenskih zdraviliščih.

Hipotezo smo preverili s pomočjo Pearsonovega korelacijskega koeficienta in analize variance ANOVA.

Preglednica I 1.5: Korelacija med prihodki na zaposlenega in dejavniki notranjih odnosov

\begin{tabular}{|c|c|c|}
\hline & & rrihode \\
\hline NOI & Pearsonova soodnosnost & 0,21 \\
\hline & Sig. (I-tailed) & ০,০০ \\
\hline & $\mathrm{N}$ & 66 \\
\hline $\mathrm{NO}_{2}$ & Pearsonova soodnosnost & 0,29 \\
\hline & Sig. (I-tailed) & o,or \\
\hline & $\mathrm{N}$ & 66 \\
\hline $\mathrm{NO}_{3}$ & Pearsonova soodnosnost & 0,16 \\
\hline & Sig. (I-tailed) & o,II \\
\hline & $\mathrm{N}$ & 66 \\
\hline $\mathrm{NO}_{4}$ & Pearsonova soodnosnost & 0,35 \\
\hline & Sig. (I-tailed) & ০,০০ \\
\hline & $\mathrm{N}$ & 66 \\
\hline $\mathrm{NO}_{5}$ & Pearsonova soodnosnost & 0,29 \\
\hline & Sig. (I-tailed) & 0,00 \\
\hline & $\mathrm{N}$ & 66 \\
\hline
\end{tabular}

Iz preglednice i 1.5 je razvidno:

- NOı: Personov koeficient znaša o,2 I. Linearna povezanost spremenljivk je nizka/šibka.

- NO2: Personov koeficient znaša 0,29. Linearna povezanost spremenljivk je nizka/šibka.

- $\mathrm{NO}_{3}$ : Personov koeficient znaša o,16. Linearne povezanosti spremenljivk je nizka/šibka. 
- NO4: Personov koeficient znaša 0,35 . Linearna povezanost spremenljivk je nizka/šibka.

- NO5: Personov koeficient znaša 0,29. Linearna povezanost spremenljivk je nizka/šibka.

Preglednica i .6: Analiza variance ANOVA, hipoteza $\mathrm{H}_{\mathrm{I}}$

\begin{tabular}{|c|c|c|c|c|c|c|}
\hline & & Vsota kvadratov & $\begin{array}{c}\text { Prostostna } \\
\text { stopnja }\end{array}$ & Vrednost kvadrata & F & Pomembnost \\
\hline \multirow[t]{3}{*}{$\mathrm{NO}$} & Med skupinami & 5,82 & 12 & 0,49 & 2,38 & 0,02 \\
\hline & Zunaj skupin & 10,8 & 53 & 0,2 & & \\
\hline & Skupaj & 16,62 & 65 & & & \\
\hline \multirow[t]{3}{*}{$\mathrm{NO}_{2}$} & Med skupinami & 10,98 & 12 & 0,92 & 2,88 & ०,০० \\
\hline & Zunaj skupin & 16,83 & 53 & 0,32 & & \\
\hline & Skupaj & 27,82 & 65 & & & \\
\hline \multirow[t]{3}{*}{$\mathrm{NO}_{3}$} & Med skupinami & 5,82 & 12 & 0,39 & 2,38 & 0,02 \\
\hline & Zunaj skupin & 10,8 & 53 & 0,30 & & \\
\hline & Skupaj & 16,62 & 65 & & & \\
\hline \multirow[t]{3}{*}{$\mathrm{NO}_{4}$} & Med skupinami & 6,72 & 12 & 0,56 & 1,72 & 0,04 \\
\hline & Zunaj skupin & 17,23 & 53 & 0,33 & & \\
\hline & Skupaj & 23,95 & 65 & & & \\
\hline \multirow[t]{3}{*}{$\mathrm{NO}_{5}$} & Med skupinami & 5,83 & 12 & 0,49 & 8,05 & 0,00 \\
\hline & Zunaj skupin & 3,2 & 53 & 0,06 & & \\
\hline & Skupaj & 9,03 & 65 & & & \\
\hline
\end{tabular}

Iz preglednice i I.6 je razvidno:

- NOı: Ocena pojasnjene variance znaša o,49. Ocena nepojasnjene variance znaša 0,20 . Pojasnjena varianca ni dovolj velika v primerjavi z nepojasnjeno, zato lahko zaključimo, da neodvisna spremenljivka nima vpliva na odvisno spremenljivko.

- $\mathrm{NO}_{2}$ : Ocena pojasnjene variance znaša o,92. Ocena nepojasnjene variance znaša 0,32 . Pojasnjena varianca ni dovolj velika v primerjavi z nepojasnjeno, zato lahko zaključimo, da neodvisna spremenljivka nima vpliva na odvisno spremenljivko.

- $\mathrm{NO}_{3}$ : Ocena pojasnjene variance znaša o,39. Ocena nepojasnjene variance znaša 0,30 . Pojasnjena varianca ni dovolj velika v primerjavi z nepojasnjeno, zato lahko zaključimo, da neodvisna spremenljivka nima vpliva na odvisno spremenljivko. 
- NO4: Ocena pojasnjene variance znaša 0,56. Ocena nepojasnjene variance znaša 0,33 . Pojasnjena varianca ni dovolj velika v primerjavi z nepojasnjeno, zato lahko zaključimo, da neodvisna spremenljivka nima vpliva na odvisno spremenljivko.

- NOs: Ocena pojasnjene variance znaša o,49. Ocena nepojasnjene variance znaša 0,06 . Pojasnjena varianca je dovolj velika v primerjavi z nepojasnjeno, zato lahko zaključimo, da neodvisna spremenljivka nima vpliva na odvisno spremenljivko.

$\mathrm{Na}$ podlagi izračunanega korelacijskega koeficienta in izračunane statistike analize variance ANOVA smo ugotovili, da dejavnik notranjih odnosov nima tako velikega pomena kot nekateri drugi dejavniki. Izračunali smo nizko/šibko povezanost med dejavnikom notranjih odnosov in dejavnikom prihodkov na zaposlenega. Prav tako izračun testa ANOVA pokaže, da je velik del variance nepojasnjen, torej ni dokazanega neposrednega vpliva notranjih odnosov na poslovanje izbranega zdravilišča. Hipoteze $\mathrm{HI}$ ne moremo potrditi.

$H_{2}$ : Motivacija in zavzetost imata signifikantno pozitiven vpliv na donosnost $v$ slovenskih $z$ dravilišč $i h$.

Hipotezo smo preverili s pomočjo Pearsonovega korelacijskega koeficienta in analize variance ANOVA.

Preglednica i r.7: Korelacija med prihodki na zaposlenega in dejavniki motivacije in zavzetosti

\section{prihodek}

\begin{tabular}{llc} 
prihodek & Pearsonova soodnosnost & I \\
\hline & Sig. (I-tailed) & 66 \\
\hline MZI & Pearsonova soodnosnost & 0,49 \\
\hline & Sig. (I-tailed) & 0,01 \\
\hline M & N & 66 \\
\hline & Pearsonova soodnosnost & 0,59 \\
\hline & Sig. (I-tailed) & 0,00 \\
\hline$M Z_{3}$ & Pearsonova soodnosnost & 66 \\
\hline & Sig. (I-tailed) & 0,36 \\
\hline & N & 0,00 \\
\hline$M Z_{4}$ & Pearsonova soodnosnost & 66 \\
\hline
\end{tabular}




\begin{tabular}{llc} 
& Sig. (I-tailed) & 0,00 \\
\hline & $N$ & 66 \\
\hline$M Z 5$ & Pearsonova soodnosnost & 0,43 \\
\hline & Sig. (I-tailed) & 0,00 \\
\hline & $N$ & 66
\end{tabular}

Iz preglednice i i.7 je razvidno:

- $\mathrm{MZ}_{\mathrm{I}}$ : Personov koeficient znaša 0,49 . Linearna povezanost spremenljivk je srednja/zmerna.

- $\mathrm{MZ}_{2}$ : Personov koeficient znaša 0,59. Linearna povezanost spremenljivk je srednja/zmerna.

- $\mathrm{MZ}_{3}$ : Personov koeficient znaša 0,36. Linearne povezanosti spremenljivk je nizka/šibka.

- $\mathrm{MZ}_{4}$ : Personov koeficient znaša o,43. Linearna povezanost spremenljivkje srednja/zmerna.

- MZ5: Personov koeficient znaša o,43. Linearna povezanost spremenljivk je srednja/zmerna.

Preglednica i .8: Analiza variance ANOVA, hipoteza $\mathrm{H}_{2}$

\begin{tabular}{|c|c|c|c|c|c|c|}
\hline & & Vsota kvadratov & $\begin{array}{c}\text { Prostostna } \\
\text { stopnja }\end{array}$ & $\begin{array}{l}\text { Vrednost } \\
\text { kvadrata }\end{array}$ & F & Pomembnost \\
\hline \multirow[t]{3}{*}{$M Z_{I}$} & Med skupinami & 3,25 & I2 & 1,27 & $\mathrm{I}, 28$ & 0,26 \\
\hline & Zunaj skupin & $\mathrm{II}, 23$ & 53 & $0,2 \mathrm{I}$ & & \\
\hline & Skupaj & 14,48 & 65 & & & \\
\hline \multirow[t]{3}{*}{$\mathrm{MZ}_{2}$} & Med skupinami & 1,96 & I2 & 0,16 & 0,6 & 0,83 \\
\hline & Zunaj skupin & 2,83 & 53 & 0,05 & & \\
\hline & Skupaj & 6,62 & 65 & & & \\
\hline \multirow[t]{3}{*}{$\mathrm{MZ}_{3}$} & Med skupinami & 3,72 & 12 & 2,31 & 0,83 & 0,62 \\
\hline & Zunaj skupin & 19,73 & 53 & 0,37 & & \\
\hline & Skupaj & 23,45 & 65 & & & \\
\hline \multirow[t]{3}{*}{$\mathrm{MZ}_{4}$} & Med skupinami & 2,63 & 12 & 0,92 & $\mathrm{I}, 82$ & 0,07 \\
\hline & Zunaj skupin & 6,4 & 53 & 0,12 & & \\
\hline & Skupaj & 9,03 & 65 & & & \\
\hline \multirow[t]{2}{*}{$\mathrm{MZ}_{5}$} & Med skupinami & 7,13 & 12 & 0,89 & 1,57 & 0,13 \\
\hline & Zunaj skupin & 20,03 & 53 & ०,०8 & & \\
\hline
\end{tabular}




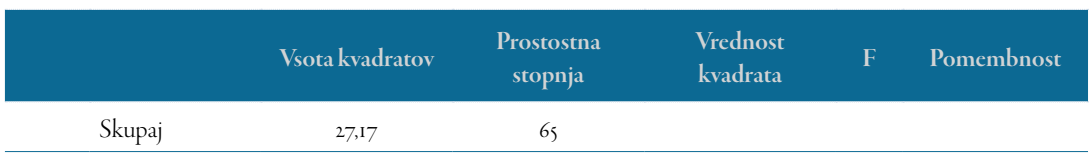

Iz preglednice I I. 8 je razvidno:

- MZI: Ocena pojasnjene variance znaša I,27. Ocena nepojasnjene variance znaša o,2r. Pojasnjena varianca je dovolj velika v primerjavi z nepojasnjeno, zato lahko zaključimo, da ima neodvisna spremenljivka vpliv na odvisno spremenljivko.

- MZ2: Ocena pojasnjene variance znaša o,16. Ocena nepojasnjene variance znaša o,05. Pojasnjena varianca je dovolj velika v primerjavi z nepojasnjeno, zato lahko zaključimo, da ima neodvisna spremenljivka vpliv na odvisno spremenljivko.

- $\mathrm{MZ}_{3}$ : Ocena pojasnjene variance znaša 2,3 I. Ocena nepojasnjene variance znaša 0,37 . Pojasnjena varianca je dovolj velika v primerjavi z nepojasnjeno, zato lahko zaključimo, da ima neodvisna spremenljivka vpliv na odvisno spremenljivko.

- $\mathrm{MZ}_{4}$ : Ocena pojasnjene variance znaša 0,92. Ocena nepojasnjene variance znaša 0, I 2 . Pojasnjena varianca je dovolj velika v primerjavi z nepojasnjeno, zato lahko zaključimo, da ima neodvisna spremenljivka vpliv na odvisno spremenljivko.

- $\mathrm{MZ}_{5}$ : Ocena pojasnjene variance znaša o,89. Ocena nepojasnjene variance znaša 0,08 . Pojasnjena varianca je dovolj velika v primerjavi z nepojasnjeno, zato lahko zaključimo, da ima neodvisna spremenljivka vpliv na odvisno spremenljivko.

Pri drugi hipotezi ugotavljamo, da obstaja srednja/zmerna povezanost med dejavnikom motivacije in zavzetostjo ter uspešnostjo poslovanja zdravilišča. Prav tako pa test ANOVA pokaže, da je velik del variance uspešnosti poslovanja pojasnjen z odstopanjem vrednosti posameznih dejavnikov motivacije in zavzetosti. Hipotezo $\mathrm{H}_{2}$ smo potrdili.

$H_{3}$ : Vodenje ima signifikantno pozitiven vpliv na donosnost $v$ slovenskih zdraviliščih.

Hipotezo smo preverili s pomočjo Pearsonovega korelacijskega koeficienta in analize variance ANOVA. 
Preglednica I I.9: Korelacija med prihodki na zaposlenega in dejavniki vodenja

prihodek

\begin{tabular}{lll} 
prihodek & Pearsonova soodnosnost & I \\
\hline & Sig. (I-tailed) & 66 \\
\hline$V_{\text {I }}$ & N & 0,46 \\
\hline & Pearsonova soodnosnost & 0,00 \\
\hline & Sig. (I-tailed) & 66 \\
\hline$V_{2}$ & N & 0,31 \\
\hline & Pearsonova soodnosnost & 0,0 I \\
\hline$V_{3}$ & Sig. (I-tailed) & 66 \\
\hline & N & 0,44 \\
\hline & Pearsonova soodnosnost & $0,1 \mathrm{I}$ \\
\hline$V_{4}$ & Sig. (I-tailed) & 66 \\
\hline & N & 0,49 \\
\hline & Pearsonova soodnosnost & 0,00 \\
\hline & Sig. (I-tailed) & 66 \\
\hline & N & 0,49 \\
\hline
\end{tabular}

Iz preglednice i 1.9 je razvidno:

- VI: Personov koeficient znaša o,46. Linearna povezanost spremenljivk je srednja/zmerna.

- V2: Personov koeficient znaša o,3 I. Linearne povezanosti spremenljivk je nizka/šibka.

- V $V_{3}$ : Personov koeficient znaša 0,44 . Linearna povezanost spremenljivk je srednja/zmerna.

- V4: Personov koeficient znaša o,49. Linearna povezanost spremenljivk je srednja/zmerna.

- V5: Personov koeficient znaša o,49. Linearna povezanost spremenljivk je nizka/šibka. 
Preglednica I I. Io: Analiza variance ANOVA, hipoteza $\mathrm{H}_{3}$

Vsota kvadratov Prostostna stopnja Vrednost kvadrata F Pomembnost

\begin{tabular}{|c|c|c|c|c|c|c|}
\hline$V_{I}$ & Med skupinami & 2,08 & 12 & 1,17 & 0,45 & 0,93 \\
\hline & Zunaj skupin & 5,63 & 53 & O,II & & \\
\hline & Skupaj & 11,76 & 65 & & & \\
\hline \multirow[t]{3}{*}{$\mathrm{V}_{2}$} & Med skupinami & 5,32 & I2 & 0,84 & I,84 & 0,07 \\
\hline & Zunaj skupin & 12,8 & 53 & 0,24 & & \\
\hline & Skupaj & $18, \mathrm{I} 2$ & 65 & & & \\
\hline \multirow[t]{3}{*}{$\mathrm{V}_{3}$} & Med skupinami & 0,74 & 12 & 0,26 & $\mathrm{I}, \mathrm{O} 2$ & 0,44 \\
\hline & Zunaj skupin & 3,2 & 53 & 0,06 & & \\
\hline & Skupaj & 3,94 & 65 & & & \\
\hline \multirow[t]{3}{*}{$\mathrm{V}_{4}$} & Med skupinami & 0,83 & I2 & 1,07 & $0,9 \mathrm{I}$ & 0,54 \\
\hline & Zunaj skupin & 17,23 & 53 & 0,33 & & \\
\hline & Skupaj & 23,95 & 65 & & & \\
\hline \multirow[t]{3}{*}{$\mathrm{V}_{5}$} & Med skupinami & 3,78 & 12 & 0,92 & $\mathrm{I}, 27$ & 0,27 \\
\hline & Zunaj skupin & 13,2 & 53 & 0,25 & & \\
\hline & Skupaj & 16,98 & 65 & & & \\
\hline
\end{tabular}

Iz preglednice i I.Io je razvidno:

- VI: Ocena pojasnjene variance znaša I,17. Ocena nepojasnjene variance znaša 0, I I. Pojasnjena varianca je dovolj velika v primerjavi z nepojasnjeno, zato lahko zaključimo, da ima neodvisna spremenljivka vpliv na odvisno spremenljivko.

- V2: Ocena pojasnjene variance znaša o,84. Ocena nepojasnjene variance znaša 0,24 . Pojasnjena varianca je dovolj velika v primerjavi z nepojasnjeno, zato lahko zaključimo, da ima neodvisna spremenljivka vpliv na odvisno spremenljivko.

- $V_{3}$ : Ocena pojasnjene variance znaša o,26. Ocena nepojasnjene variance znaša 0,06 . Pojasnjena varianca je dovolj velika v primerjavi z nepojasnjeno, zato lahko zaključimo, da ima neodvisna spremenljivka vpliv na odvisno spremenljivko.

- V4: Ocena pojasnjene variance znaša I,07. Ocena nepojasnjene variance znaša 0,33 . Pojasnjena varianca je dovolj velika $v$ primerjavi z nepojasnjeno, zato lahko zaključimo, da ima neodvisna spremenljivka vpliv na odvisno spremenljivko.

- V5: Ocena pojasnjene variance znaša o,92. Ocena nepojasnjene variance znaša 0,25 . Pojasnjena varianca je dovolj velika v pri- 
merjavi z nepojasnjeno, zato lahko zaključimo, da ima neodvisna spremenljivka vpliv na odvisno spremenljivko.

Srednja/zmerna korelacijska odvisnost je v večini primerov izračunana tudi med dejavniki vodenja. S pomočjo izračuna statistike ANOVA smo ugotovili, da je velik del variance donosnosti posameznega slovenskega zdravilišča pojasnjen z dejavniki vodenja v teh zdraviliščih. Hipotezo $\mathrm{H}_{3}$ sprejmemo.

Na podlagi izračunov ugotavljamo, da lahko organizacijska klima pozitivno vpliva na poslovanje zdravilišč. $S$ tega vidika ugotavljamo, da je v slovenskih zdraviliščih smiselno razvijati organizacijsko klimo, saj bomo na ta način zagotovili še boljše poslovanje.

\section{Sklepi iz raziskave}

Primerjava rezultatov s povprečjem med zdravilišči, vključenimi v raziskavo, pokaže določena odstopanja tako v pozitivni kot v negativni smeri. Nekoliko večja pozitivna odstopanja od povprečja se kažejo v kategorijah nagrajevanje, vodenje ter motivacija in zavzetost. To pomeni, da so zaposleni v zdraviliščih, ki imajo večji dohodek na zaposlenega, tem kategorijam dali višjo oceno od povprečne ocene drugih sodelujočih podjetij. Negativno pa od povprečja odstopajo kategorije notranji odnosi, pripadnost organizaciji, odnos do kakovosti, razvoj kariere, strokovna usposobljenost in učenje ter poznavanje poslanstva in vizije ter ciljev, kjer so zaposleni z nižjim prihodkom na zaposlenega tem kategorijam dali nižje ocene od povprečja.

Zaposleni v organizacijah so kategorije organizacijske klime v večini ocenili kot srednje dobre. Najboljše ocene so dobile kategorije: odnos do kakovosti, motivacija in zavzetost ter inovativnost in iniciativnost. Srednjo pozicijo med ocenjenimi kategorijami zasedajo: pripadnost organizaciji, organiziranost, strokovna usposobljenost in učenje, poznavanje poslanstva in vizije ter ciljev. Najslabše pa so zaposleni ocenili: notranje odnose, nagrajevanje, notranje komuniciranje in informiranje ter razvoj kariere.

Odnos do kakovosti je po ocenah anketiranih ena izmed najvišje ocenjenih kategorij klime. Za kakovost svojega dela se zaposleni počutijo odgovorne, prav tako se tudi trudijo dosegati standarde kakovosti. Kakovost in količina dela se zdita zaposlenim dokaj enako pomembni. V organizacijskih enotah imajo jasno zastavljene cilje, vendar pa drugih sodelavcev in organizacijskih enot ne obravnavajo vedno kot cenjene stranke. 
Kategorijo motivacija in zavzetost so anketirani ocenili precej visoko, saj je poleg odnosa do kakovosti najvišje ocenjena kategorija organizacijske klime. Večina zaposlenih je pri delu pripravljena vložiti dodaten napor, kadar je to potrebno, hkrati menijo, da so $\mathrm{v}$ organizaciji postavljene dokaj visoke zahteve glede delovne uspešnosti. Zaposleni so tudi zavzeti za svoje delo. Dober delovni izid v podjetju srednje hitro opazijo.

Kategorija inovativnost in iniciativnost je med tremi najbolje ocenjenimi kategorijami organizacijske klime. Zaposleni se večinoma zavedajo nujnosti sprememb $\mathrm{v}$ zdravilišču in precej pogosto izboljšujejo in posodabljajo svoje storitve. $\mathrm{V}$ zdravilišču se pogosto pričakuje, da predloge za izboljšave dajejo vsi, ne zgolj vodje, zaposleni pa so do srednje mere tudi pripravljeni prevzeti tveganje za uveljavitev svojih pobud. Manj so v organizaciji sprejemljive napake, ki se pojavijo med preskušanjem novih načinov dela.

Kategorija vodenje je med srednje ocenjenimi kategorijami. Zaposleni menijo, da so večinoma samostojni pri svojem delu. V zdravilišču so pogovori nadrejenih s podrejenimi o izidih dela precej pogosti. Vodje pa do določene mere zaposlene tudi spodbujajo $k$ sprejemanju večje odgovornosti za njihovo delo.

Kategorija pripadnost organizaciji je bila med srednje ocenjenimi. Kaže se v pozitivnem govorjenju zaposlenih o lastnem zdravilišču ter njihovem ponosu, da so zaposleni ravno tukaj. Menijo, da ima njihovo zdravilišče precejšnji ugled $\mathrm{v}$ družbenem okolju. Manj se strinjajo $s$ trditvijo, da je zaposlitev varna oziroma zagotovljena. Najmanjša pripadnost organizaciji se kaže $\mathrm{v}$ odhodu zaposlenih $\mathrm{v}$ primeru znižanja plače zaradi poslovnih težav.

Kategorija organiziranost je bila med srednje ocenjenimi. Anketirani zaposleni imajo precej jasno predstavo o tem, kaj se od njih pri delu pričakuje. Malce manj razumejo svoj položaj v organizacijski shemi zdravilišča, vendar še vedno dokaj dobro. Menijo, da so zadolžitve dobro opredeljene, odločitve vodij pa se včasih ne sprejemajo pravočasno, prav tako pa pristojnosti in odgovornosti na različnih nivojih organiziranosti med seboj niso uravnotežene.

Kategorija strokovna usposobljenost in učenje je bila po višini ocen organizacijske klime v sredini. Zaposleni se učijo od drugih sodelavcev in menijo, da organizacija potrebno usposabljanje za dobro opravljanje dela nudi le delno. Menijo, da sistem usposabljanja ni najboljši ter da so v zdravilišču zaposleni tudi sodelavci, ki niso ustrezno usposobljeni za svoje delo. Prav tako se želje anketiranih pri načrtovanju usposabljanja ne upoštevajo vedno. 
Tudi kategorija poznavanje poslanstva in vizije ter ciljev je med srednje ocenjenimi kategorijami, z nižjo oceno kot kategorija strokovna usposobljenost in učenje. Anketirani so ocenili, da imajo v zdravilišču oblikovano poslanstvo ter da zaposleni sprejemajo cilje zdravilišča. Delno se strinjajo $s$ trditvijo, da so cilji, ki jih morajo doseči, realno postavljeni. Manj se jim zdijo jasni cilji in politika organizacije, pri postavljanju ciljev pa, poleg vodij, drugi zaposleni ne sodelujejo pogosto.

Kategorija notranji odnosi je med nižje ocenjenimi kategorijami organizacijske klime. K notranjim odnosom največ prispeva spoštovanje dela sodelavcev, ki je znotraj kategorije ocenjeno najvišje. Odnosi med zaposlenimi so dobri, zaposleni pa včasih med seboj sodelujejo, včasih pa tekmujejo. Konflikti se ne razrešujejo v skupno korist, prav tako si zaposleni včasih ne zaupajo.

Uspešnost se navadno vrednoti po dogovorjenih ciljih in standardih. Menijo, da za slabo opravljeno delo sledijo ustrezne sankcije. Anketirani prejemajo plačo, ki je enakovredna ravni plač na tržišču. Ne strinjajo pa se s trditvijo, da so tisti, ki so bolj obremenjeni, tudi ustrezno stimulirani. Najslabše zaposleni ocenjujejo ustreznost razmerij med plačami v zdravilišču.

Anketirani so kategorijo notranje komuniciranje in informiranje ocenili nizko, predvsem pa na to vpliva mnenje, da dobijo odločno premalo informacij o tem, kaj se dogaja v drugih enotah. Posredovanje informacij s strani vodstva je nerazumljivo, poleg tega nadrejeni dajejo dovolj, drugič premalo informacij za dobro opravljanje dela zaposlenih. Komunikacijo med sodelavci in vodji so ocenili kot prijateljsko in sproščeno, redni pa so tudi delovni sestanki.

Razvoj kariere so anketirani ocenili kot najnižjo med dvanajstimi kategorijami organizacijske klime v organizaciji. Najvišjo oceno znotraj kategorije ima postavka, ki se nanaša na zadovoljstvo z dosedanjim osebnim razvojem, ki je bila ocenjena s srednjo oceno. Kriteriji za napredovanje niso jasni vsem zaposlenim, prav tako zaposleni nimajo realnih možnosti za napredovanje.

Kategorija zadovoljstvo pri delu je bila ocenjena visoko. Najbolj so anketirani zadovoljni z delovnim časom in $s$ sodelavci. Tudi s samim delom so zadovoljni. Zaposleni so zadovoljni s svojimi neposredno nadrejenimi ter $s$ stalnostjo zaposlitve. Zadovoljstvo z delovnimi pogoji je visoko, zadovoljni so s svojim statusom in $\mathrm{z}$ možnostmi za izobraževanje. Zadovoljstvo s plačo je visoko in se nahaja $\mathrm{v}$ rangu zadovoljstva $\mathrm{z}$ možnostmi za izobraževanje. Niso pa zadovoljni z vodstvom podjetja in $\mathrm{z}$ možnostjo za napredovanje. 
In če za konec povemo še, kaj pomeni višja povprečna ocena posameznih dejavnikov organizacijske klime glede na letni prihodek na zaposlenega: ugotovili smo, da je slednji v zdraviliščih, $v$ katerih organizacijsko klimo ocenjujejo boljše, višji kot $\mathrm{v}$ zdraviliščih, kjer so posamezni dejavniki slabše ocenjeni. Na osnovi preverjanja pravilnosti hipotez $\mathrm{H}_{\mathrm{I}}, \mathrm{H}_{2}$ in $\mathrm{H}_{3}$ smo ugotovili, da je letni prihodek na zaposlenega v soodvisnosti z organizacijsko klimo. V zdravilišču v kate,rem je organizacijska klima na višjem nivoju, je tudi letni prihodek na zaposlenega višji. Dokazali smo, da organizacijska klima pozitivno oziroma negativno vpliva na letni prihodek na zaposlenega v izbranih slovenskih zdraviliško-turističnih centrih.

\section{Predlogi ukrepov za izboljšanje organizacijske klime}

$\mathrm{Na}$ podlagi vseh izsledkov iz raziskave navajamo naslednje predloge za izboljšanje organizacijske klime:

- Z nagradami motivirati zaposlene: obstaja veliko teorij o tem, kaj motivira zaposlene, in ugotovili bomo, da se sodelavci različno odzivajo, ko jim predstavimo spodbude za uspešnost. Sodelavci bodo bolj motivirani, če bodo menili, da je nagrada kapital v organizaciji. Odpravlja videz favoriziranja in priznavanja dosežkov.

- Spodbujati novativnost in podjetniški duh: ustvarjanje podjetniškega duha se začne $s$ preoblikovanjem sodelavcev $\mathrm{v}$ gospodarski $\gg$ motor « zdraviliško-turističnih centrov. Eden od načinov za pospeševanje podjetništva je, da se organizacijska enota vzpostavi kot profitni center in se zaposlenim omogoči, da morebitne dobičke, ustvarjene s pomočjo prihrankov in povečanja prodaje, usmerijo v tisto, kar mislijo, da je najboljše za organizacijo. Prav tako naj $\mathrm{v}$ podjetju posameznikom ponujajo nagrade za inovativne ideje in plačilo licenčnine za prihodke, ustvarjene s patentirano idejo ipd.

- Pripraviti sodelavce na spremembe: odpor do sprememb se kaže v mnogih simptomih, ki lahko ustvarijo neprimerno organizacijsko klimo. Priporočamo, da se spremembe uvajajo v točno določenih obdobjih. Če je sprememba za vsakogar sezonskega značaja, to ne bo nikogar presenetilo.

- Spodbujati povezanost zaposlenih: organizacijska klima je izboljšana, ko sodelavci občutijo povezavo ali vez s svojimi kolegi. Tudi če ima vsak zaposleni drugačno delo znotraj organizacije, 
je treba poenotiti osnovni namen vsega, kar počnejo, da se s tem poveže organizacija kot celota. Povezovanje naj bo takšno, da zaposleni razumejo in vidijo, kako je njihovo delo povezano v celoto in kakšni učinki so v tej celoti.

- Izpostavljati pomen zaposlenih in njihovega dela: sodelavci želijo, da je njihovo delo pomembno in da imajo nekaj nadzora nad končnim izdelkom oziroma v našem primeru storitve. Opolnomočenje vodi v boljšo izvedbo, saj so zaposleni, ki so najbližje delu izdelka, sposobni najti probleme hitreje in imajo več idej o tem, kako izboljšati učinkovitost.

- Razviti iskrene komunikacije in s tem graditi zaupanje: prepričati se je potrebno, da organizacija jasno in pogosto komunicira $\mathrm{z}$ zaposlenimi o pravem stanju, vključno z nalogami, s cilji, finančnim stanjem, z dosežki in napakami organizacije. Nihče ne mara slabe novice, ampak zaupanje nikoli ne bo zaživelo v organizaciji, ki z zaposlenimi ne deli tako dobrih kot slabih novic. To bi vodilo v govorice, podpihovanje, kar vsekakor ne bi pripomoglo $\mathrm{k}$ boljši klimi. Težav ne pometamo pod preprogo, o njih se posvetujemo tudi z zaposlenimi. Tako bomo, namesto da bi jih preložili na prihodnji čas, ko bodo še izrazitejše, težave odpravili v začetni fazi.

\section{Prispevek k znanosti}

Na podlagi empiričnih rezultatov raziskave smo prišli do novih in doslej še neugotovljenih razlik med posameznimi zdraviliško-turističnimi centri v Republiki Sloveniji. Na ta način smo prišli do novih spoznanj, ki bodo imela praktične ter teoretične koristi za vse tiste, ki se ukvarjajo z managementom organizacij, s poudarkom na dejavniku organizacijske klime.

\section{Predlogi za nadaljnje raziskovanje}

$\mathrm{Na}$ podlagi rezultatov raziskave predlagamo, da bi se organizacijska klima v obravnavanih slovenskih zdraviliščih merila vsakoletno, saj bi s tem omogočili longitudinalno primerjavo. Ugotavljali bi lahko, ali so organizacije teoretična izhodišča za boljšo organizacijsko klimo uspele uspešno implementirati v prakso. $\mathrm{Na}$ ta način bi se lahko organizacije, ki pri prvem merjenju niso bile tako uspešne, primerjale med seboj ter ugotavljale pozitivne znake na poti k dobro delujoči organizaciji s pomočjo dobre organizacijske klime v podjetju. 
Pridobljeno strokovno znanje bodo tako lahko aplicirale v prakso, izidi analize bodo primerjani s povprečjem $\mathrm{v}$ Sloveniji. Na podlagi pridobljenih rezultatov bodo lahko oblikovani predlogi in ukrepi za izboljšanje določenih ugotovljenih šibkih dimenzij, ki jih morebiti v organizaciji še ni uspelo popraviti. Letna primerjava rezultatov bo pokazala tudi učinke uvajanja ukrepov za izboljšanje določenih dimenzij, ki so morebiti šibke na ravni celotne dejavnosti.

Kljub temu da so storitvene dejavnosti, kamor spada zdraviliška dejavnost, specifične, pa bi bilo zanimivo v prihodnje rezultate merjenja organizacijske klime v slovenskih zdraviliščih primerjati s povprečjem merjenja organizacijske klime v vseh drugih sodelujočih slovenskih podjetjih.

Glede na to, da nismo zasledili, da se podobna merjenja opravljajo v tujini, bi bilo smiselno izvesti podobno merjenje tudi med tujimi oziroma nam sosednjimi zdravilišči, predvsem v Italiji, Avstriji, na Madžarskem in Hrvaškem, ter jih primerjati s slovenskimi.

\section{Literatura}

Brezovec, A. 2000. Marketing v turizmu. Portorož: Turistica.

Florjančič, J., in J. Jesenko. 1997. Management v turizmu. Kranj: Moderna organizacija.

Gojčič, S. 2005. Wellness: zdrav način življenja, nova zvrst turizma. Ljubljana: GV Založba. 



\section{Recenziji}

Glavna tema monografske publikacije sta organizacijska kultura in organizacijska klima. Monografska publikacija ima poleg predgovora še enajst sklopov, od tega dva vsebinska. Prvi vsebinski sklop vsebuje šest sklopov in zgoščeno prikazuje teoretična izhodišča s področja organizacijske kulture in klime. S pomočjo temeljnega pregleda literature $s$ tega področja je opredeljen pomen kulture in klime za organizacijo, predstavljene so dosedanje pomembne tuje raziskave $\mathrm{z}$ obravnavanega področja in koncepti spreminjanja kulture ter klime v organizaciji. Glede na to, da imata tako kultura (makro okolje poslovnega sistema) kot klima (mikro pogled poslovnega sistema) enak pomen za organizacijo, je razvoju obeh treba posvetiti enako pozornost. $\mathrm{V}$ ta namen so na koncu prvega vsebinskega sklopa nazorno predstavljene podobnosti ter razlike med kulturo in klimo ter koristi preučevanja kulture za proučevanje klime $\mathrm{v}$ organizaciji in obratno.

Drugi vsebinski sklop predstavlja pet raziskav raziskovalcev z obravnavanega področja v Sloveniji, ki do sedaj še niso bile opravljene. Poleg izčrpnega opisa posameznih raziskav (metodologija, vzorec, rezultati) so podrobno predstavljeni predlogi za izboljšave, predlogi za nadaljnje raziskovanje ter prispevek $\mathrm{k}$ znanosti. $\mathrm{Na}$ ta način so $\mathrm{v}$ monografski publikaciji predstavljene raziskava organizacijske kulture v izbrani večji organizaciji javnega sektorja, raziskava organizacijske kulture v slovenskih gledališčih, raziskava organizacijske kulture in dodane vrednosti v tujih podjetjih v Sloveniji, raziskava vpliva organizacijske kulture v izbranih srednje velikih in velikih podjetjih v Sloveniji na odstotek bolniškega do- 
pusta zaposlenih in raziskava o organizacijski klimi v trinajstih slovenskih zdraviliščih.

Monografsko publikacijo priporočam za izdajo, ker predstavlja pomemben teoretični, raziskovalni in empirični prispevek z implikacijami na znanost, stroko ter prakso na področju kulture in klime v organizaciji v Sloveniji, v EU in tudi širše.

\section{Bostjan Antončič}

\section{II}

Monografija Organizacijska kultura in organizacijska klima - teorija, pra$k s a$ in raziskave $v$ Sloveniji, katere urednika in avtorja sta dr. Melita Moretti in prof. dr. Mirko Markič (s soavtorji), obsega i I poglavij, ki so smiselno zaokrožena na dva vsebinska sklopa.

V prvem sklopu, ki obsega 6 poglavij, monografija poda pregled dosedanjih tujih raziskav s področja organizacijske kulture in organizacijske klime, ki so imele največji vpliv na tem področju. $\mathrm{V}$ tem delu monografija tudi pojasni pomen in vlogo organizacijske kulture in organizacijske klime za organizacijo ter v primeru, ko stari veljavni postopki za doseganje uspešnosti in učinkovitosti organizacije niso zadostni, na primerih dobrih praks prikaže načine spreminjanja obeh konstruktov. Na koncu prvega sklopa sledi poglavje, kjer sta povezana oba konstrukta, prikazane so podobnosti in razlike med njima ter poudarjeno, kako lahko raziskave in ostala preučevanja oziroma ugotovitve enega koristijo drugemu ter obratno, saj oba konstrukta, tako organizacijska kultura kot organizacijska klima, $v$ znanstveno in poslovno sfero prinašata različna pogleda na organizacijo.

V drugem sklopu, ki obsega pet poglavij, so predstavljeni rezultati izvedenih raziskav raziskovalcev s področja organizacijske kulture in organizacijske klime v Sloveniji.

- Prvi primer govori o raziskavi organizacijske kulture v izbrani organizaciji javnega sektorja, ki je bila izvedena v vseh njenih 13 organizacijskih enotah,

- drugi primer je raziskava organizacijske kulture v slovenskih gledališčih,

- tretji primer je raziskava organizacijske kulture in dodane vrednosti v tujih podjetjih v Sloveniji, 
- četrti primer je raziskava vpliva organizacijske kulture v izbranih srednjih in velikih podjetjih v Sloveniji na odstotek bolniškega dopusta zaposlenih, a

- peti primer je raziskava o organizacijski klimi v I3 slovenskih zdraviliščih.

Poleg izčrpnega opisa posameznih raziskav so predstavljeni predlogi za izboljšave, prispevek $\mathrm{k}$ znanosti in predlogi za nadaljnje raziskovanje.

Pokaže se, da sta organizacijska kultura in organizacijska klima kot mehka dejavnika uspeha pri delovanju in dobrega počutja udeležencev ter deležnikov organizacije pomembna $\mathrm{v}$ praktično vseh tipih organizacij. Pred leti smo vzpostavili krog osebne vrednote (vplivnih) $\bullet$ kultura etika norme osebne vrednote . . kot sliko, kako organizacijska kultura nastane in vpliva, a na dosti načelnejši ravni kot $v$ tej monografiji, ki je tudi zato dragocena.

Tema monografije je zelo aktualna. Organizacijska kultura in organizacijska klima predstavljata dva organizacijska dejavnika, ki sta zelo neposredno povezana z vsemi ostalimi elementi organizacije in njenim okoljem ter vsemi posamezniki v organizacijah v Sloveniji in EU, ne le danes, ampak tudi v prihodnosti. Poznavanje in obvladovanje organizacijske kulture in organizacijske klime je ključnega pomena za vse organizacije, tako na področju javnega kot zasebnega sektorja, saj se vsaka sprememba kulture in klime odraža na vseh ostalih področjih v organizaciji:

- spremembe organizacijske kulture se odražajo v strategiji, razvoju, strateških ciljih, stabilnosti, organiziranosti, splošni rasti, globalni interakciji organizacije,

- spremembe organizacijske klime pa v operativnih in procesnih elementih organizacije, kot so postopki, politika, kratkoročni cilji, struktura zaposlenih, operacionalizacija in načini poslovanja organizacije.

Čeprav se v monografiji predstavljene empirične raziskave nanašajo na slovensko okolje, so obravnavane raziskave in teme danes pomembne za celotno EU in tudi širše. Tovrstna dela lahko med teoretiki, raziskovalci in managerji povečajo zavest o pomenu organizacijske kulture in organizacijske klime za vse vrste organizacij, zato delo zelo priporočam za izdajo. 


8

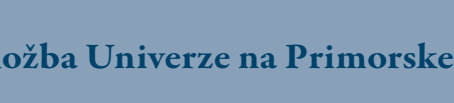

